\title{
Visies op HBO en beroepspraktijk : een exploratief onderzoek naar visies van experts op de toekomstige relatie van $\mathrm{HBO}$ en beroepspraktijk
}

Citation for published version (APA):

Frederix, L. L. M. (1988). Visies op HBO en beroepspraktijk : een exploratief onderzoek naar visies van experts op de toekomstige relatie van HBO en beroepspraktijk. [, Maastricht University]. Rijksuniversiteit Limburg. https://doi.org/10.26481/dis.19881118lf

Document status and date:

Published: 01/01/1988

DOI:

10.26481/dis.19881118lf

Document Version:

Publisher's PDF, also known as Version of record

Please check the document version of this publication:

- A submitted manuscript is the version of the article upon submission and before peer-review. There can be important differences between the submitted version and the official published version of record.

People interested in the research are advised to contact the author for the final version of the publication, or visit the DOI to the publisher's website.

- The final author version and the galley proof are versions of the publication after peer review.

- The final published version features the final layout of the paper including the volume, issue and page numbers.

Link to publication

\footnotetext{
General rights rights.

- You may freely distribute the URL identifying the publication in the public portal. please follow below link for the End User Agreement:

www.umlib.nl/taverne-license

Take down policy

If you believe that this document breaches copyright please contact us at:

repository@maastrichtuniversity.nl

providing details and we will investigate your claim.
}

Copyright and moral rights for the publications made accessible in the public portal are retained by the authors and/or other copyright owners and it is a condition of accessing publications that users recognise and abide by the legal requirements associated with these

- Users may download and print one copy of any publication from the public portal for the purpose of private study or research.

- You may not further distribute the material or use it for any profit-making activity or commercial gain

If the publication is distributed under the terms of Article 25fa of the Dutch Copyright Act, indicated by the "Taverne" license above, 
VISIES OP HBO EN BEROEPSPRAKTIJK 



\section{VISIES OP HBO EN BEROEPSPRAKTIJK}

Een exploratief onderzoek naar visies van experts op de toekomstige relatie van $\mathrm{HBO}$ en beroepspraktijk

\section{P R OEFS C H R I T}

ter verkrijging van de graad van doctor aan de Rijksumiversiteit Limburg te Maastricht, op gezag van de Rector Magnificus, prof.dr. F.I.M. Bonke, volgens het besluit van het College van Dekanen, in het openbaar te verdedigen op 18 november 1988 om 14.00 uur

door

LEON LOUIS MARIE FREDERIX

geboren in 1948 te Klimmen 


\section{PROMOTORES:}

prof,dr. W.H.F.W. Wijnen

prof.dr. A.J.A. Felling

Katholieke Universiteit Nijmegen

BEOORDELINGSCOMMISSIE:

prof.dr. F. Sturmans

dr. H.J.M. van Berkel

prof.dr. J.A.M. Heijke

dr. F. Huijgen

Katholieke Universiteit Nijmegen

prof.dr. B. van Onna

Katholieke Universiteit Nijmegen

prof.dr. H. Philipsen 


\section{Inhoudsopgave}

WOORD VOORAF

ix

1. SITUERING VAN DE PROBLEMATIEK EN HET UTTGEVOERDE ONDERZOEK

$1.1 \quad$ Inleiding

1.2 Karakter en plaats van deze studie

1.3 Aspecten van de verhouding van onderwijs en arbeid 8

1.3.1 Een onderscheid in drie partijen 8

1.3.2 Een onderscheid in drie spanningsbronnen 9

1.3.3 De positie van deze studie ten opzichte van aansluitingsdiscussies en -onderzoek

2 HET THEORETISCH KADER 15

2.1 Drie centrale elementen $\quad 15$

$\begin{array}{ll}2.1 .1 & 15\end{array}$

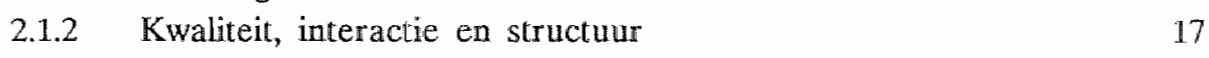

2.1.2.1. Kwaliteits-aspecten $\quad 19$

2.1.2.2 Interactie-aspecten 20

2.1.2.3 Structuur- en organisatie-aspecten $\quad 22$

2.1.3 Samenvatting van de hoofdpunten 23

$2.2 \quad$ Enkele relevante aspecten nader uitgewerkt 23

$2.2 .1 \quad$ Visies op functies van het $\mathrm{HBO} \quad 23$

2.2 .2 Beroepskwalificatie als doel van het HBO 25

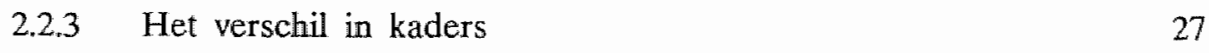

$\begin{array}{lll}2.3 & \text { Tot besluit } & 28\end{array}$

3 KWALTEITSASPECTEN 29

3.1. Inleiding 29

3.2 Visies op rendement van onderwijs 29

$3.3 \quad$ Visies op kwaliteit $\quad 32$

3.3.1. Kwaliteit als thema $\quad 32$

3.3.2 Visies op kwalliteit en kwalificatie 33

3.3.3 Het begrip kwalificatie 33

3.3.4 Ontwikkelingen in de kwalificatie en de interactie van
onderwijs- en beroepspraktijk

3.3.5 Toekomstige ontwikkelingen 35

3.3.6 Drie visies op het kwalificatiebegrip 37 
3.4 Het begrip kwalificatie in deze studie 38

3.4.1. De gekozen tweedeling in kwalificaties 39

3.4.2 Specifieke elementen van het kwaliteitsbegrip 40

3.4.3 Het aparte belang van sociaal-normatieve kwalificaties 41

3.4.4 Uitwerking van de aspecten 42

$\begin{array}{ll}3.5 & \text { Samenvatting } \\ & 45\end{array}$

4. INTERACTIE-ASPECTEN $\quad 46$

4.1 Inleiding 46

4.2 Onderwijs in een bredere context/De maatschappelijke rol $\begin{array}{ll}\text { van het onderwijs } & 46\end{array}$

4.3 Aspecten van het interactiebegrip $\quad 50$

4.3.1 Onderwijs en arbeid als twee werelden 50

4.3.2 De oriëntatie op de beroepspraktijk 51

4.3.3 De invloed van de markt op het onderwijs 54

4.3.4 Het verschil in cultureel klimaat $\quad 57$

4.3.5 De C.O.A.-bijdragen en omgevingsgericht onderwijs 57

$\begin{array}{lll}4.4 & \text { Samenvatting } & 59\end{array}$

5 STRUCTUUR- EN ORGANISATIE-ASPECTEN 60

5.1. Inleiding 60

5.2 Het nieuwe kader voor het HBO 60

5.2.1 Toekomstig Hoger Onderwijs in discussie 62

5.3 Mega-trends voor toekomstige ontwikkeling 64

5.3.1 Algemene trends 64

5.3.2 Zeven trends, relevant geacht voor toekomstig HBO 66

$\begin{array}{lll}5.4 & \text { Samenvatting } & 69\end{array}$

6 PROBLEEMSTELLING EN ONDERZOEKSOPZET

$\begin{array}{lll}6.1 & \text { Inleiding } & 70\end{array}$

$\begin{array}{lll}6.2 & \text { Probleemstelling } & 70\end{array}$

$\begin{array}{lll}6.2 .1 & \text { Korte beschrijving } & 70\end{array}$

6.2.2 De positie van de respondenten/verschillen in kaders 72

$\begin{array}{lll}6.3 & \text { De instrumentconstructie } & 72\end{array}$

6.3.1 Operationalisering van de elementen kwaliteit, interactie, structuur en organisatie 73

6.3.2 Operationalisering van participatie en invloedsuitoefening
in beleidsontwikkeling

$\begin{array}{lll}6.4 & \text { De formatie van de respondentengroep } & 74\end{array}$ 
6.4.1 Positionele en reputatiebenadering bij de steekproefsamenstelling

6.4.2 De sneeuwbaltechniek in de reputatie-methode

6.4.3 Aanvullend gebruik van de positiemethode voor de steekproefbepaling

6.5 Het survey-onderzoek $\quad 80$

6.5.1 De survey-beschrijving $\quad 80$

$\begin{array}{lll}\text { 6.6 De informantengroep } & 82\end{array}$

6.6.1 Representativiteit $\quad 82$

6.6.2 Hoofdkarakteristieken van de respondenten in het kort 83

6.6.3 Betrokkenheid als kenmerk van de informanten 84

7 HET ONDERZOEK NAAR DIMENSIES $\quad 88$

$\begin{array}{lll}7.1 & \text { Inleiding } & 88\end{array}$

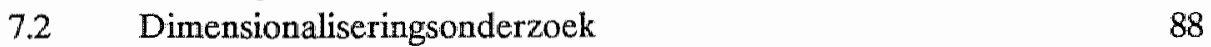

7.2.1 Het conceptuele systeem van de informanten 88

7.2.2 Principale componentenanalyse/de structuur van de factoren en de interpretatie $\quad 89$

7.2.3 Subdimensies binnen de factoren; de concepten 94

7.2.4 De factoriële structuur binnen relevante subgroepen 99

$\begin{array}{lll}7.3 & \text { Resumé met betrekking tot de aangetroffen dimensies } & 100\end{array}$

$\begin{array}{ll}7.4 & \text { Samenvattende beschouwing } \\ & 101\end{array}$

8 HET ONDERZOEK NAAR PRIORTTETTEN EN PATRONEN 102

$\begin{array}{lll}8.1 & \text { Inleiding } & 102\end{array}$

8.2 De prioriteit van de concepten 102

8.3 De eerste resultaten van het onderzoek naar verschillen in visies 105

8.4 Prioriteiten binnen het domein kwaliteit 107

8.5 Prioriteiten binnen het domein inderactie 111

8.6 Prioriteiten binnen het domein structuur en organisatie 113

$\begin{array}{lll}8.7 & \text { Conclusies } & 115\end{array}$

9 CONCLUSIES EN PERSPECTIEVEN 116

9.1 Inleiding 116

9.2 Resumé van het theoretische deel 116

9.3 Conclusies met betrekking tot de dataverzameling in

9.4 Conclusies met betrekking tot dimensionaliteit 119 
9.5 Conclusies met betrekking tot de prioritering van de boofdcomponenten

9.6 Conclusies met betrekking tot de oorspronkelijke hoofddomeinen kwaliteit-interactie-structuur/organisatie

9.6.1 Kwaliteit

9.6.2 Interactie

9.6.3 Structuur en organisatie

9.6.4 Een grafische weergave van de invloed van sectoren

9.7 Conclusies met betrekking tot de expertness van de respondenten

9.8 Correspondentie-analyse

9.8.1 Inleiding

9.8.2 Kwaliteit

9.8.3 Interactie

9.8.4 Structuur en organisatie

9.9 Enkele perspectieven

9.9.1 Inleiding

9.9.2 Relativering van de traditionele tegenstelling 140

9.9.3 Belang en functie van gestructureerd overleg 142

9.9.4 Suggesties voor methodische en praktische follow up

10 SUMMARY

REFERENTIES

BLJLAGEN 


\section{Woord vooraf}

Deze publikatie is het verslag van een onderzoek naar visies op de toekomstige ontwikkeling van het HBO in relatie tot de beroepspraktijk.

De mensen die hun ideeën ten dienste stelden van dit onderzoek waren experts met een reputatie op dat terrein, woonachtig en werkzaam in de provincie Limburg. De studie is bedoeld als verkenning. Ze stelt vast hoe mensen - met een zekere deskundigheidsreputatie - denken over enkele relevante aspecten van hoger beroepsonderwijs in de toekomst. Wij hopen met deze publikatie een bijdrage te kunnen leveren aan de discussie van allen die bij de vormgeving van de toekomst van het $\mathrm{HBO}$ èn de relatie van het $\mathrm{HBO}$ met de beroepspraktijk, betrokken zijn.

De ervaring leerde dat het verrichten van onderzoek arbeidsintensief is en tijd kost. De studie is gebaseerd op een theoretische analyse die medio 1985 werd afgesloten. De tot dan ten aanzien van de toekomst van het HBO geldende discussie en standpuntbepalingen zijn meegenomen voor zover ze relevant waren voor het kernthema van deze studie.

Het vooronderzoek - gericht op het opsporen van informanten - heeft plaatsgevonden in de zomer van 1985, het survey-onderzoek - gericht op de verzameling van visies - werd afgenomen in de periode september-november van dat jaar. De dataverzameling werd op 1 december 1985 gestopt. Data-analyse, verder overleg en tussenrapportages werden uitgevoerd in 1986 en 1987. Het manuscript werd in 1988 afgerond en drukgereed gemaakt.

De mensen in het veld met wie in de voorbereiding en de uitvoering van het onderzoek contact heeft plaatsgevonden zijn wij erkentelijk. Steun werd ondervonden van dr. G. Fragnière, directeur van het "European Centre for Work and Society" te Maastricht en de medewerkers van dit Instituut.

De idee voor het onderzoek is ontstaan in samenspraak met prof.dr. W.H.F.W. Wijnen te Maastricht. Hij heeft de totstandkoming van de studie èn het manuscript als promotor op inspirerende wijze begeleid. Onze dank geldt hem en prof. dr. A.J.A. Felling te Nijmegen, die ons niet alleen met tal van methodologische adviezen maar ook met opbouwende kritiek zeer geholpen heeft. Drs. M.J.G. Luppes te Heerlen heeft een deel van de data-analyse verricht in het kader van zijn afstudeer-opdracht. 
Onze dank geldt evenzeer prof.dr. H. Teichler, wan het Wissenschaftliches Zentrum für Berufs- und Hochschulforschung te Kassel (B.R.D.), met name voor zijn adviezen in de fase van de data-interpretatie.

Wij zijn allen, die anderszins een bijdrage leverden, erkentelijk voor hun hulp, die ons er mede toe in staat stelde dit proefschrift bij de Rijksuniversiteit Limburg aan te bieden. Bijzondere dank komt toe aan Mimi Coonen, Monique Appels en Els Smeele van Intercai B.V. voor hun toegewijde arbeid bij de afzonderlijke versies van het manuscript. De grafische verzorging was in de vakkundige handen van Bureau Infobever te Nijmegen. 


\section{Situering van de problematiek en het uitgevoerde onderzoek}

\subsection{INLEIDING}

De verhouding van onderwijs en arbeid is onderwerp van tal van beschouwingen, zowel door de breedte van het onderwerp als door het belang dat aan een effectieve relatie wordt toegekend. De verhouding wordt van commentaar voorzien vanuit een veelheid van standpunten - al dan niet op grond van legitieme belangen - vertegenwoordigd door tal van partijen zowel aan de onderwijs- als aan de arbeidszijde. De som van deze commentaren biedt een bont conglomeraat van opvattingen.

Door de maatschappelijke ontwikkelingen en de consequenties daarvan voor de vormgeving van onderwijs en arbeid en de relatie van beide, valt aan te nemen dat de belangstelling voor dit onderwerp zal toenemen. Dit resulteert zowel in een grotere vraag naar onderzoek, als naar meer gecoördineerd onderzoek (cf. Hövels en Peschar, 1985).

In navolging van Van Hoof en Dronkers (1980) zijn, ten aanzien van de discussie over de relatie onderwijs en arbeid, drie belangrijke achtergronden te onderscheiden:

- de grote werkloosheid;

- de kwalitatieve discrepanties tussen vraag naar en aanbod van arbeidskrachten;

- de klachten over het functioneren van schoolverlaters in de werksituatie.

Van Hoof en Dronkers stellen ten aanzien van de vaak eenzijdige discussies over de verhouding van onderwijs en arbeild: "De rode draad die door dit soort opmerkingen heenloopt is dat de ontwikkelingen in het onderwijs de voornaamste schuld van aansluitingsproblemen tussen onderwijjs en arbeidsmarkt dragen." (1980, p 14). Gelet op de visies op de talrijke hervormingsvoorstellen van de afgelopen jaren voor zowel het lager en middelbaar als het hoger en wetenschappelijk onderwijs, is dit geen boude bewering. 
In toenemende mate wordt de aandacht gericht op ontwikkelingen op de arbeidsmarkt en het arbeidsmarktsysteem, die mede van invloed zijn op de aansluitingsproblemen én de aansluiting op zichzelf (cf. Nijssen en Brons, 1978; Van Hoof en Dronkers, 1980; Vlaskamp en Hövels, 1980). Veel studies op het terrein van de relatie van onderwijs en arbeid bewegen zich op het gebied van de beschrijving van de structuren zoals die bestaan in en tussen de systemen onderwijs en arbeid. Dit onderzoek gaat een stap verder: wat zijn de achterliggende dimensies in de beoordeling van de relatie van onderwijs en beroepspraktijk, door mensen die betrokken zijn bij deze problematiek? Deze vraag interesseert ons omdat terzake van de verhouding van onderwijs en arbeid in literatuur en praktijk een bont spectrum van opinies leeft en de veelzijdigheid van het probleem een oplossing niet bevordert.

Voorts is interessant hoe de toekomstig gewenste relatie eruit zou moeten zien, de vraag of mensen uit het onderwijs en de beroepspraktijk er wezenlijk verschillende ideeën op na houden (cf. Schouten, 1977) en op welke wijze men vanuit de verschillende posities denkt tot nadere afstemming te komen. De relatie van het onderwijs en de beroepspraktijk is een onderwerp van brede strekking. Zonder nadere afbakening kan in principe ieder debat over aspecten van onderwijs en beroepspraktijk onder de noemer van de relatie van beide worden gebracht. Ons vertrekpunt ligt in de bovenbeschreven overwegingen; deze sluiten aan bij een veel gebruikte dichotomie in de aansluitingsstudies: de kwantitatieve en kwalitatieve aansluiting.

De hoofdlijnen van de discussies over en de beoordeling van de relatie onderwijs en beroepspraktijk worden in deze studie teruggebracht tot:

- visies op de kwaliteit van de onderwijsopbrengst;

- visies over de interactie tussen onderwijs en beroepspraktijk;

- visies op de structuur van het onderwijs.

Wij zullen op de keuze van deze drie elementen in hoofdstuk 2 en volgende nader ingaan. In dit hoofdstuk worden allereerst het karakter en de plaats van de studie aangegeven (par. 1.2). Daarna worden enkele visies op de onderlinge verhouding van onderwijs en arbeid geschetst en een onderscheid aangebracht in relevante partijen en specifieke spanningsbronnen (par. 1.3). Het hoofdstuk besluit met een schets van de plaats van dit onderzoek ten opzichte van aansluitingsdiscussies en -onderzoek (par. 1.4). 
De studie is gericht op het opsporen van lokale leiders ên op een nadere identificatie van het onderzochte probleemveld. Dit laatste is gebeurd door het in kaart brengen van visies én het bevragen van lokale leiders over kernpunten uit de discussie over de relatie van $\mathrm{HBO}$ en beroepspraktijk. Daarmee is de studie geen klassieke analytisch-empirische evaluatie van de aansluiting van $\mathrm{HBO}$ en beroepspraktijk maar is exploratief van karakter. $\mathrm{Zij}$ beoogt ook geen aansluitingsonderzoek of manpowerplanning te zijn (vgl. Bilderbeek en Smits, 1985).

De studie vertrekt vanuit het gegeven dat de verhouding van $\mathrm{HBO}$ en beroepspraktijk vanuit tal van posities wordt beoordeeld en van commentaar c.q. suggesties wordt voorzien. Er is bepaald geen sprake van én - substantiële kadertheorie of een afgeronde zienswijze waarover uiteenlopende partijen consensus hebben bereikt. Integendeel, er is sprake van divergente visies, dit geldt zowel ten aanzien van de rol van het onderwijs in het algemeen, als ten aanzien van de relaties van het $\mathrm{HBO}$ met de beroepspraktijk.

Elfectief overleg tussen opleiding en werkveld en gerichte studies over de toekomst van het $\mathrm{HBO}$ en de verhouding met de beroepspraktijk zijn echter gewenst, gelet op het belang dat allerwegen aan een goede relatie van $\mathrm{HBO}$ en beroepspraktijk wordt toegekend. Deze studie onderzoekt de visies die lokale leiders hebben op de eerder geschetste relatie. $\mathrm{Zij}$ beoogt bij te dragen aan een deel van de oplossing van het probleem van de relatie HBO - beroepspraktijk en is toekomstgericht. De doelstelling is te komen tot een verheldering van visies en verwachtingen die mensen uit verschillende sectoren met betrekking tot de materie hebben. De vraag, of en hoe deze in kaart te brengen zijn vormt het kernpunt van de studie die uiteindelijk is gericht op het verbeteren van de relatie van onderwijs en arbeid, de dialoog tussen partijen en het ontwikkelen van bouwstenen voor belleid.

Bilderbeek en Smits (1985 pag. 9 e.v.) stellen in het verband van de relatie van onderwijs en arbeid dat "De relatie kan worden beschouwd als een complex probleemgebied dat onder invloed van de maatschappelijke dynamiek is uitgegroeid tot een van de centrale vraagstukken voor de beleidsvorming op dit terrein". Hoewell niet de enige factor, vormt de technologische ontwikkeling een drijvende kracht achter het dynamische proces van maatschappelijke verandering. Een complicerende factor is de omstandigheid dat er tussen technologische en arbeidsmarktontwikkelingen in hun algemeenheid moeilijk een rechtstreekse relatie is te leggen. Weliswaar is duidelijk dat toepassing 
van technologische vernieuwingen in de praktijk leidt tot veranderingen in de wraag naar arbeid, en in de kwalificatie en beroepenstructuur, maar de aard en omvang van deze veranderingen kunnen sterk uiteenlopen. In dit opzicht vormen onder meer beslissingen genomen op micro-niveau (het niveau van het bedrijf), bijvoorbeeld met betrekking tot de gekozen arbeidsorganisatorische inbedding van de technologische vernieuwing, een bron van variatie. Algemene uitspraken over de aard en omvang van het effect van technologische vernieuwing op arbeid in kwalitatieve en kwantitatieve zin, zoals ook blijkt uit de literatuur, zijn nauwelijks te doen. De stand van de kennis en de theorie-ontwikkeling op dit terrein bieden hier te weinig houvast. Bilderbeek en Smits concluderen "dat het dan ook moeilijk is verantwoord voorspellingen van enige betrouwbaarheid te doen over de toekomstige ontwikkelingen op de arbeidsmarkt, en wel in het bijzonder de vraagkant." (op. cit., pag. 10) Hoewel algemeen wordt aangenomen dat het aanpassingsvermogen van het arbeids- en onderwijsbestel in de toekomst zwaar op de proef zal worden gesteld, lijkt het, gegeven de grote onzekerheid omtrent de aard en richting van de in het verschiet liggende veranderingen, moeilijk te anticiperen anders dan door middel van flexibilisering aan de aanbodkant.

In dit kader citeren zij met instemming Nijssen en Brons (1978), die in een evaluatiestudie van prognostisch onderzoek naar de verhoudingen tussen vraag en aanbod van bepaalde opleidingscategorieën opmerken dat "... in de oplossingen (...) die neerkomen op flexibilisering van het aanbod door vooral wederkerend onderwijs (of her-, om- en bijscholing) op de opvatting berusten dat de prognose "er zullen in de toekomst grote veranderingen plaatsvinden in de vraag naar arbeid" niet verder gedetailleerd kan worden". (op. cit. pag. 58 e.v.)

De onzekerheid over aard en richting van de toekomstige veranderingen maakt dat de huidige situatie verschillend kan worden opgevat. Dit wordt nog versterkt door de omstandigheid dat de stand van kennis en theorie-ontwikkeling ten aanzien van het probleemveld een flinke interpretatieruimte openlaat.

$\mathrm{Nu}$ is er een scalla van wetenschappelijke technieken beschikbaar ten dienste van sociaal onderzoek. Voor een plaatsbepaling van deze studie - in relatie tot potentieel bruikbare technieken voor voortgezette beleidsontwikkelingrefereren wij aan een publikatie van Geurts, Hart en Caplan (1985, p. 242 e.v.). Zij schetsen hierin een typologie van onderscheiden besluitvormingssituaties waarbij drie dimensies worden aangegeven: 
* dimensie 1

m.b.t fasen in het besluitvormingsproces, te onderscheiden in:

- probleemherkenning en formulering;

- optie-generering en evaluatie;

- optie-selectie en implementatie.

* dimensie 2

m.b.t. de "state of knowledge" d.w.z. de aard van de beschikbare kennis en de kwaliteit daarvan. Hierin worden 4 niveaus onderscheiden:

- zekerheid;

- risico;

- onzekerheid;

- ambiguiteit;

* dimensie 3

m.b.t. de "decision situations" of "modes" met als niveaus:

- één individu in een organisatie;

- een kleine groep in een organisatie;

- een collectief of een gehele organisatie.

Indien de drie dimensies in een matrix worden geplaatst resulteert een raamwerk dat klassificatie van onderscheiden decisie-problemen mogelijk maakt. Ons onderzoek is op te vatten als voorfase voor Delphi-studies en workshops als techniek voor het bereiken van consensus en verdere besluitvorming. Deze technieken, toegepast in de optie-generering en evaluatie-fase, behoeven vooraf probleemdefinitie en formulering. Het opsporen en nader specificeren van visies vindt in dit onderzoek plaats.

Wat de state of knowledge betreft: veel publikaties met betrekking tot de relatie van $\mathrm{HBO}$ en beroepspraktijk zijn te klassificeren op het niveau van ambiguiteit. De relewante variabelen zijn weliswaar bekend, maar de kennis over de onderlinge interacties is beperkt of compleet afwezig. Op het opsporen van visies en dimensies in betekenisgeving is deze studie mede gericht.

Wat de decision situations betreft, vertrekt deze studie vanuit de aanname dat visies van mensen op het thema van onderzoek worden bepaald door hun positie, met name de vraag of zij behoren tot de sector onderwijs-, arbeids- of intermediaire organisaties. Aan het opsporen van verschillen in de wijze van denken over de relatie van onderwijs en arbeid wordt door ons ruime aandacht besteed. 
Besluitwormingsprocessen inzake complexe problemen verlopen niet sequentieel en lineair. Probleemoplossing is te beschouwen als een iteratief proces van probleemverheldering en herformulering. Er is een voortdurende behoefte om te werk te gaan op basis van een zich ontwikkelend begrip van het probleem. Geurts e.a.(1985) tonen aan hoe besluitvorming inzake complexe problemen een mix van techmische data en normatieve opvattingen en voorkeuren van tal van betrokkenen bij het besluitvormingsproces inhoudt. Verwezen wordt naar schema 1 dat deze samenhang illustreert.

\section{Schema 1:}

Grafische weergave van aspecten en de samenhang daarvan, bij probleemontwikkeling

globaal idec

wan cen problecm

handel op basis van
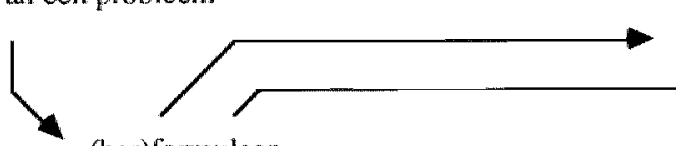
probleemformulering

(her) rormuleer probleem
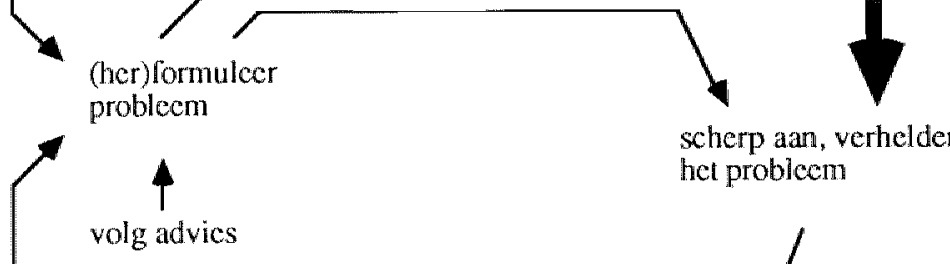

scherp aan, verhelder het problecm
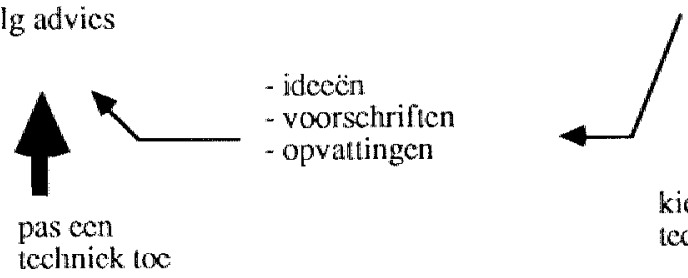

kies cen technick
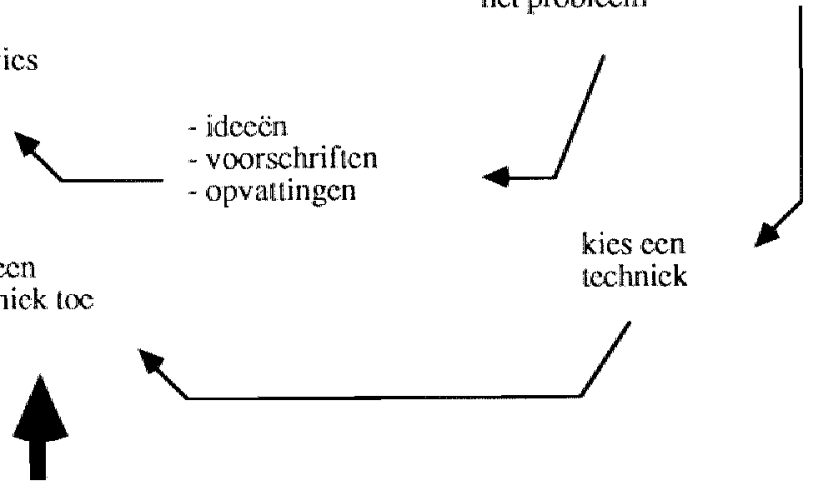

De omvang en de divergentie van ideeën, commentaren en standpunten die met betrekking tot de relatie van hoger beroepsonderwijs en beroepspraktijk worden verwoord zijn aanleiding om te onderzoeken of de visies en verwachtingen meer objectief in kaart kunnen worden gebracht en tor welke conclusies dit kan leiden. 
Over de precieze aard en omvang van de discrepanties tussen onderwij]s en arbeid is tot nu toe weinig bekend. Weinig informatie is voorhanden over de resultaten van pogingen daarvoor oplossingen te vinden. $\mathrm{Er}$ is nog weinig, systematische en voor het beleid hanteerbare, informatie beschikbaar. Een oorzaak hierwan is, dat tot nu toe, het onderzoek op het terrein van de relatie van onderwijs en arbeid een te incidenteel karakter heeft gehad en niet uitgesproken toekomstgericht is.

Wij beogen, door middel van het onderzoeken van opvattingen, bij te dragen aan verbeldering van enkele aspecten van de relatie van $H B O$ en beroepspraktijk en de visies van relevante actores op de toekomst daarvan. In de fase van probleemdefinitie en formulering kunnen de uitkomsten van het onderzoek dienen als basis voor voortgezette beleidsstudies (optiegenering en evaluatie). Daarbij kan onder meer gedacht worden aan workshops van experts uit de onderscheiden sectoren, Delphi studies en andere technieken die voor beleidsontwikkelingen op het terrein van dit onderzoek relevant zijn. Op basis van het materiaal zou een spelsimulatie geschreven kunnen worden. Met behulp daarvan kunnen de onderscheiden elementen van kwaliteit, interactie en structuur in hun onderlinge samenhang gezien en beoordeeld worden. Uiteindelijk kan dit resulteren in een systeemdynamisch model ten behoeve van het ontwikkelen van handelingsscenario's voor toekomstig beleid. De ontwikkeling van een gemeenschappelijk referentiekader en taalveld voor de toekomstige samenspraak van experts met een uiteenlopende achtergrond kan daaraan bijdragen. Op het ontwikkelen van cognitieve hulpmiddelen is deze studie mede gericht. Daartoe zijn twee soorten onderzoeken uitgevoerd.

- Er is een informantengroep samengesteld en deze groep mensen is vervolgens met een schriftelijk survey benaderd. Dit bevatte een aantal uitspraken ontleend aan de actuele discussie over HBO en beroepspraktijk en is gebaseerd op een literatuuronderzoek. De hoofdlijnen van de onderzoeksvraag (zoals in de vragenlijst geoperationaliseerd) worden in hoofdstuk $2 \mathrm{t} / \mathrm{m} 5$ verder uitgewerkt.

De studie is beperkt tot de provincie Limburg, het daar gevestigde $\mathrm{HBO}$, de arbeidsorganisaties en de intermediaire organisaties. De generaliseerbaarheid van hetgeen onderzocht werd, is daarmee beperkt. De begrenzing tot de provincie Limburg maakte wel een onderzoek naar "expertness" ên de visies van de geraadpleegde experts mogelijk, alsmede de hopelijke voortzetting van de provinciale beleidsontwikkeling met behulp van spelsimulatie en andere daarwoor adequate technieken. 


\subsection{ASPECTEN VAN DE VERHOUDING WAN ONDERWIS EN ARBEID}

Alvorens de opvattingen en standpunten worden uitgewerkt, wordt een overzicht gegeven van relevante aspecten, partijen en spanningsbronnen. Deze zijn niet specifiek voor het $\mathrm{HBO}$, ze gelden ook voor andere vormen van beroepsonderwijs. De opvatting, dat het onderwijs deel uitmaakt van het maatschappelijk bestel staat hierbij centraal. Onderwijs is geen zelfstandige grootheid waarbinnen ontwikkelingen onafhankelijk van de maatschappij plaatsvinden, maar wordt opgevat als resultante van maatschappelijke ontwikkelingen, waarbij institutionalisering van onderwijs uiteindelijk leidt tot een zekere mate van autonomie. Een autonomie die telkens opnieuw wordt bevochten en verdedigd en van velerlei zijden van commentaar wordt voorzien. (vgl. voor een samenvattende beschouwing b.v. Frederix 1978, van Kemenade 1981, van Wieringen 1984).

Als in het kader van deze studie wordt gesproken over visies op het onderwijs, zijn daarbij ook visies op de functies van het onderwijs aan de orde. In het verlengde daarvan ligt het onderzoek naar de beoordeling van deze functies, gerelateerd aan de relevantie voor de beroepspraktijk.

\subsubsection{Een onderscheid in drie partijen}

Sprekend over de verhouding beroepspraktijk en het $\mathrm{HBO}$, worden twee entiteiten gebruikt die met elkaar in verbinding staan. Van Hoof en Dronkers (1980, p.25) hanteren in dit verband de termen onderwijssysteem en arbeidssysteem en definiëren deze respectievelijk als "... het onderdeel van dat maatschappelijk deelsysteem waarin de belangrijkste socialisatieprocessen zich afspelen." en "... het onderdeel van het economisch systeem (te omschrijven) als het geheel van posities waarin arbeid wordt verricht (...), de rellaties daartussen en de normen die het verrichten van arbeid en de relaties tussen arbeidsplaatsen reguleren."

Zij brengen een onderscheid aan met het begrip arbeidsmarkt. Dit wordt niet beschouwd wordt als onderdeel van het arbeidssysteem, maar als tussenschakel tussen onderwijs- en arbeidssysteem. De arbeidsmarkt is een van de mechanismen om divergerende ontwikkelingen in onderwijs- en arbeidssysteem met elkaar in overeenstemming te brengen, met als doel het bij elkaar brengen van vraag en aanbod.

Aldus ontstaat een drieledig onderscheid. Dit onderscheid is van belang omdat de mate van flexibiliteit van de arbeidsmarkt eventuele discrepanties tussen onderwijs en beroepspraktijk kan absorberen en omdat de structuur en het 
functioneren van de arbeidsmarkt op zichzelf ook een aparte bron van discrepanties tussen onderwijs en beroepspraktijk kan zijn (cf. Hövels en Peschar, 1985; Van Hoof en Dronkers, 1980; van Gravendeel en Krijnen, 1975). Instituten op dit terrein vormen een belangrijke bron van informanten bij dit onderzoek. Daarom zijn ook informanten uit op de arbeidsmarkt werkzame organisaties opgenomen zoals het Contactcentrum Onderwijs Arbeid, de Gewestelijke Arbeidsbureaus en de Stichtingen voor School- en Beroepskeuze. Deze zijn in deze studie verder aangeduid als intermediaire organisaties.

Gegeven de complexiteit van de verhouding van onderwijs en arbeid komt allereerst een resumé van de gevoerde discussie inzake spanningen in de verhouding van beide aan de orde.

\subsubsection{Een onderscheid in drie spanningsbronnen}

Hövels (1984, p. 45 e.v.) wijst, in een omgevingsverkenning van de relatie van onderwijs en arbeid, op drie structurele spanningsbronnen in de verhouding van onderwijs en arbeid:

- De structureel-technische spanningsbron verwijst naar de institutionele afschotting tussen het reguliere onderwijssysteem en het reguliere arbeidssysteem als relatief zelfstandige maatschappelijke subsystemen. Elk van beide subsystemen heeft een heterogeen karakter en ontwikkelt zich voortdurend op een bepaalde wijze. Afhankelijk van de ontwikkeling lijkt het onderwijssysteem haast per definitie achter te lopen bij ontwikkelingen in het arbeidssysteem.

- De structureel-politieke spanningsbron verwijst naar de strijd om voorrang tussen verschillende doelstellingen van het onderwijssysteem; het fungeren als toeleverancier van gekwalificeerde arbeidskrachten voor het arbeidssysteem én het behouden van een zekere distantie ten opzichte van het arbeidssysteem, welke tot uitdrukking komt in haar eigen pedagogische, persoonsgerichte en bredere maatschappelijke functie.

Deze twee genoemde spanningsbronnen verwijzen primair naar de kwalificatiefunctie van het onderwijs en de mate waarin het onderwijs de mogelijkheden heeft, om deze functie te effectueren in de richting van behoeften van het arbeidssysteem.

- De structureel-distributieve spanningsbron verwijst naar de selectie-, allocatie- en legitimatiefuncties van het onderwijssysteem. De interne opbouw 
van het onderwijssysteem, onderwijsinterne selectieprocessen en de uitstroom uit de onderscheiden onderwijstypen- en niveaus kunnen (in meer en in mindere mate) corresponderen met de interne opbouw van bet arbeidssysteem en haar behoefte aan arbeidskrachten op arbeidsplaatsen van verschillende hiërarchische niveaus. Aansluitingsproblemen zijn, met andere woorden, niet alleen kwalificatieproblemen maar kunnen tot op zekere hoogte ook beschouwd worden als verdelingsproblemen (Hövels, 1984, p. 46).

Hövels toont aan dat de combinatie van genoemde spanningsbronnen continu aanleiding kan zijn tot divergerende ontwikkelingen tussen onderwijssysteem en arbeidssysteem. Het karakter van (bepaalde soorten) aansluitingsproblemen is echter in sterke mate historisch en maatschappelijk bepaald. Aansluitingsproblemen uiten zich niet steeds in dezelfde vorm en worden niet steeds op dezelfde wijze gedefinieerd. Vooral algemeen maatschappelijke doelstellingen en ontwikkelingen zijn hierop van invloed.

\subsubsection{De positie van deze studie ten opzichte van aansluitingsdiscussies en -anderzoek}

In deze paragraaf stellen wij vast hoe deze studie zich verhoudt tot het aansluitingsdiscussies en -onderzoek.

In zijn, omgevingsverkenning op het gebied van de aansluiting tussen onderwijs en arbeid wijst Hövels erop, dat uit het veld steeds meer geluiden doorklinken over inhoudelijke afstemmingsproblemen tussen de vraag naar en het aanbod van kwalificaties. Bij de bespreking van vragen waarvoor het onderwijsbeleid gesteld zal worden - gegeven de nu bestaande aansluitingsproblemen - noemt Hövels een aantal vraagpunten en dilemma's, onder meer terzake van een kernaspect als personeels- en kwalificatievoorziening:

- de mate waarin bedrijfs(specifieke) opleidingen een rol kunnen spelen in kwalificeringsprocessen;

- de structuur, vorm en inhoud van praktijkgedeelten in opleidingen;

- de verantwoordelijkheidsverdeling voor (onderdelen van) het onderwijs; alsmede

- de mate waarin en de wijze waarop onderwijsvoorzieningen (o.a. naar regio en beroepssector) moeten en kunnen worden gepland op grond van vooruitzichten met betrekking tot de werkgelegenheid. 
Tegen de achtergrond van een overzicht van wat thans feitelijk wordt ondernomen door beleid en veld, noemt Hövels twee aspecten meer opvallend:

- de combinatie van aandacht voor beroepskwalificering tijdens de gehele beroepsloopbaan en de beroepskwalificering van schoolverlaters;

- de ambiguiteit met betrekking tot de aard en de structuur van de beroepsvoorbereiding; een rechtstreekse koppeling aan kwalificatie-eisen vanuit het arbeidssysteem versus een flexibele voorbereiding op de arbeid.

Hieruit blijkt, opnieuw, de verbondenheid van onderwijs- en beroepspraktijk. De relatie van beide systemen is uitvoerig onderzocht, maar het is opvallend dat weinig onderzoek is gedaan naar de visies - van relevante personen - op de gewenste mate van aansluiting tussen onderwijsopbrengst en werkveldeisen en het specifieke karakter van die aansluiting. Dit onderzoek is er nu op gericht juist de visies van relevante personen op de verhouding van $\mathrm{HBO}$ en beroepspraktijk in kaart te brengen.

In een overzicht van, voor de analyse van de aansluiting van onderwijs en arbeid veel gebruikte, modellen schetsen Vlaskamp en Hövels (1981) het Robinsohnmodel en het Communicatiemodel. De essentie ervan luidt als volgt:

- Het Robinsohn-model, ontwikkeld in de Bondsrepubliek vanaf 1967, vormt de aanzet om te komen tot een totaal-curriculum; een systeem dat via systematische onderzoeksmethoden curriculumbeslissingen voorbereidt die op rationele maatschappelijke consensus berusten. Onderwijs moet toerusten voor levenssituaties; het model legt de relatie tussen het onderwijs en de levenssituatie waarin mensen dienen te functioneren. Er is bij het bepalen van curriculuminhouden ruimte voor andere perspectieven dan alleen die, welke de vakwetenschappen aandragen.

- In het Communicatiemodel worden onderwijsdoelstellingen geconfronteerd met functie-eisen. De confrontatie kan de vaststelling mogelijk maken van discrepanties. Het model is een gestructureerd en gedocumenteerd contact tussen opleiding en beroepspraktijk.

Zeker aan het communicatiemodel kan niet méér betekenis worden toegekend dan dat van een middel ten behoeve van de communicatie tussen onderwijs en beroepspraktijk. De pretenties van de ontwikkelaars van dit model reikten niet verder. "Onzes inziens", aldus Vlaskamp en Hövels (1980, p. 90) "is in discussies over de waarde en betekenis van het communicatiemodel het instru- 
mentele karakter van het model nogal eens verward met een vermeende betekenis in theoretische zin, die eraan zou kunnen worden toegekend". De twee modellen onderscheiden zich verder van het functie-inventarisatie-onderzoek. Zij geven informatie over de aansluiting als resultaat, dat wil zeggen over de mate waarin het aanbod van kwalificaties overeenkomt met de benutting van kwalificaties. In het Communicatiemodel gebeurt dit explicieter dan in het Robinsohnmodel. Ondanks het feit dat Robinsohn de bedoeling zegt te hebben bestaande curricula te reviseren, besteedt hij in zijn model niet expliciet aandacht aan een systematische analyse van deze curricula. Het Communicatiemodel heeft uitdrukkelijk de bedoeling onderwijsdoelstellingen met functieeisen te confronteren. Een kern van dit model is de analyse van onderwijsdoelstellingen. In de tweede plaats wordt aansluiting als resultaat - zeker in het communicatiemodel - vrij eng opgevat. De nadruk wordt gellegd op instrumenteel- technische kwalificaties. Bovendien wordt er louter aandacht besteed aan de benutting van kwalificaties, terwijl de vraag naar kwalificaties daaraan gelijk wordt gesteld. In die zin vertoont dit type onderzoek gelijkenissen met de "functie-inventarisatie"-onderzoeken.

Noch in het communicatiemodel noch in het Robinsohnmodel wordt aandacht besteed aan aansluiting als proces. De functies worden als gegevenheden opgevat en er worden geen relaties gelegd tussen de wijze waarop de arbeid wordt verdeeld en de daaruit resulterende vraag naar en benutting van kwalificaties. De invloed van de vormgeving en verdeling van de arbeid op het ontstaan van de aansluitingsproblematiek en de mogelijkheden tot oplossing van de aansluitingsproblemen door een herindeling van de arbeild worden daardoor niet of nauwelijks onderzocht.

Daarnaast introduceren Vlaskamp en Hövels het begrip kwalificatie alls verbindende schakel tussen onderwijs en arbeidsmarkt. Hiermee kan een verbreding plaatshebben van de optiek en de theoretische basis van het sociologisch arbeidsmarktonderzoek. "Het kwalificatiebegrip betekent een doorbreking van het tot dusver rechtlijnige denken over de relatie tussen onderwijs en arbeidsmarkt". (1980, pag. 108).

Tot dusver is arbeidsmarktonderzoek sterk gericht geweest op de vraag naar en het aanbod van categorieën beroepsbeoefenaren op de externe arbeidsmarkt. De analyse van discrepanties op de arbeidsmarkt geschiedde op grond van vraag/ aanbodvergelijkingen. Discrepanties in de functievervulling werden wel geconstateerd, maar vooral opgevat als een onvoldoende afstemming tussen onderwijs en beroepspraktijk (anders gesteld: vraag en aanbod passen eigenlijk wel op elkaar, maar kennis, houdingen en vaardigheden van de beroepsbeoefenaren stemmen niet voldoende overeen met de eisen die in de functie worden gesteld). 
De oplossing van deze discrepanties werd dan vooral als taak van het onderwijs gezien. De introductie van het kwalificatiebegrip maakt een meer zuivere analyse mogelijk van discrepanties tussen onderwijs en arbeidsmarkt.

De kwalificatie van een persoon wordt niet gelijkgesteld met een bepaald diploma, zoals tot dusver in veel onderzoek naar de relatie tussen onderwijs en arbeidsmarkt geschiedde. Kwalificatie wordt opgevat als het geheel van kennis, houdingen en vaardigheden dat iemand in staat stelt arbeidsprestaties te verrichten. Het kwalificatiebegrip impliceert derhalve ook de kwalificerende effecten van het opdoen van beroepservaring.

Gevraagde kwalificaties en benutte kwalificaties worden voorts niet zonder meer gelijkgesteld. De relatie hiertussen wordt juist als probleem opgevat. Het onderscheiden van gevraagde en benutte kwalificaties betekent dat men de arbeidsmarkt niet louter opvat als geheel van buiten de arbeidsorganisatie plaatsvindende processen (de externe arbeidsmarkt), maar dat men oog krijgt voor de interne arbeidsverdeling in de werkorganisaties en voor de allocatie van arbeidskrachten over de functies (de interne arbeidsmarkt).

De toenemende schaarsteverhoudingen plaatsen de arbeidsmarkt als maatschappelijk verdelingsmechanisme steeds meer op de voorgrond. De cruciale rol die de vraagzijde daarbij speelt, is duidelijk geworden. Anders dan in een periode waarin de vraag naar arbeidskrachten het aanbod overtreft, wordt het steeds minder zinvol de arbeidsmarkt te analyseren zonder de verdelingsfunctie van de arbeidsmarkt in de analyse te betrekken. Het kwalificatiebegrip maakt dergelijke analyses beter mogelijk dan het traditionele aansluitingsbegrip, omdat daarin vooral aansluiting als resultaat voorwerp van studie is. Hierbij kan de vraag worden gesteld naar de wijze waarop de discrepanties tussen de aanwezige kwalificaties van arbeidskrachten en de feitelijke benuttingsmogelijkheden op de arbeidsplaatsen zijn verdeeld. Dat lijkt o.a. een kwestie van zowel kwalitatieve als kwantitatieve arbeidsverdeling te zijn. Vervolgens kan dan de vraag aan de orde komen naar de mate waarin sociale ongelijkheid zich manifesteert in de wijze waarop arbeidsplaatsen aan personen worden toebedeeld. Dit is een vraag met betrekking tot de maatschappelijke arbeidsverdeling: welke andere factoren dan de feitelijke kwalificaties waarover iemand beschikt, spelen een rol op de arbeidsmarkt?

$\mathrm{Na}$ dit resumé van twee veel gebruikte modellen bij aansluitingsonderzoek en de kritiek van Vlaskamp en Hövels daarop, kunnen wij vaststellen hoe dit onderzoek zich daarmee verhoudt: 
- Het onderhavige onderzoek beoogt geen aansluiting te prognostiseren, noch een relatic tussen manpowerplanning en educational planning te realiseren (vgl. Bilderbeek en Smits, 1985). Het is gericht op het verzamelen en analyseren van visies van actores op aspecten die inzake de relatie van onderwijs- en beroepspraktijk relevant worden geacht.

- Het door ons uitgewerkte onderzoeksvoorstel is meerzijdiger dan het Communicatiemodel en minder breed opgezet dan gebruikelijk is bij het Robinsohnmodel. Het onderzoek richt zich niet op het analyseren van de bestaande aansluiting of gewenste aansluiting tussen opleidingssysteem en beroepspraktijk maar brengt visies op enkele aspecten van de verhouding van onderwijs en arbeid in kaart.

Daarbij gaan wij niet te werk volgens een van de bovengeschetste modellen. Wij gaan verder en brengen visies op kwalitatieve aansluitingsaspecten in verband met visies op het grotere geheel, te weten op interactie- en structuuraspecten. Ons vertrekpunt ligt in het analyseren van visies op de kwaliteit van abituriënten en het antwoord dat het Hoger Beroepsonderwijs op dit punt wordt verondersteld te geven op behoeften en vragen uit de arbeidssector.

- Veel van de arbeid, met betrekking tot het in kaart brengen van gewenste onderwijsopbrengst, wordt gekenmerkt door een afweging van veronderstelde - kwantitatieve - behoeften en een raming van te leveren opbrengst in relatie tot die behoeften. Afgezien van enkele aanzetten op deelgebieden is er geen meer-omvattende beoordeling bekend van in de toekomst nodige en muttige kwalificaties, waarbij deze laatste zijn opgevat als onderwijseindprodukt.

Onze verwachting is dat de visie op de in de toekomst gewenste onderwijsopbrengst een thema is, dat samenhangt met de visies op de functies van onderwijs en arbeid in het algemeen, de plaats en autonomie van een school in relatie tot de omgeving en tot de beroepspraktijk en samenhang vertoont met visies op de structuur en organisatie van het onderwijs als zodanig. Deze drie elementen worden verder onderzocht. 


\subsection{DRIE CENTRALE ELEMENTEN}

\subsubsection{Inleiding}

Uit de literatuur over de relatie van $\mathrm{HBO}$ en beroepspraktijk en een analyse van de functie van het $H B O$, zijn drie hoofdlijnen van de discussie gekozen: - de kwaliteit van de HBO-output in de toekomst;

- de interactie tussen het HBO en de relevante beroepspraktijk;

- de structuur van het toekomstig HBO qua organisatie.

De essentie van de discussie op deze punten, alsmede de verschillen in visies, worden beschreven. De functie van het $\mathrm{HBO}$ als overbrenger van de beroepsgerichte kwalificaties is daarbij centraal gesteld. Het is deze functie die de meningen doet variëren en aanleiding geeft tot uiteenlopende stellingnamen. Het oordeel dat mensen hebben over de doelstelling lijkt mede te worden bepaald door de visies die men heeft op de kwaliteit van de HBO-abituriënten, gezien in termen van rendement, praktische bruikbaarheid en inzetbaarheid. In de visies worden, in het algemeen, oorzaken aangegeven die verwijzen naar de interactie tussen het $\mathrm{HBO}$ en de beroepspraktijk (eventuele discrepanties terug te voeren op de "vertaling" van vereiste kwalificaties in gevraagde kwalificaties; cf. Van Hoof en Dronkers, 1980) en/of naar de structuur van het onderwijs (problemen terug te voeren op overzienbaarheid, nabijheid, bekendheid, leerinhouden e.d.).

Als uitgangspunt in dit onderzoek geldt dat visies op de kwaliteit van de HBO-opbrengst kunnen worden beschreven in termen van (gepercipieerd) feitelijk resultaat. Dit is gebeurd door relevante actores uitspraken over de toekomstige kwaliteit van de HBO-output voor te leggen. Om verbanden tussen visies op de deelgebieden kwaliteit, interactie en structuur op te sporen werd respondenten eveneens gevraagd naar hun mening over deze aspecten. Hiermee is de probleemstelling globaal geschetst. De relatie tussen wensen ten aanzien van de kwaliteit, de interactie tussen het $\mathrm{HBO}$ en de beroepspraktijk én de 
structuur van het $\mathrm{HBO}$ qua organisatie wordt in deze studie dus voorondersteld. Grond daarvoor is dat de afnemer van het eindprodukt van het HBO op grond van ervaring beschikt over ideeën met betrekking tot de inzetbaarheid van de abituriènt. Daamaast heeft de actor in de beroepspraktijk visies die zijn gebaseerd op praktische ervaring met de vraag hoe dit beroepsonderwijs én de beroepspraktijk met elkaar in betrekking staan.

Daaraan voegden wij een element toe: de visies op de structuur van het $\mathrm{HBO}$ qua organisatie. De primaire vraag is nu of uiteenlopende respondenten hetzelfde conceptuele kader hanteren bij de beoordeling van deze elementen en tevens of en op welke wijze visies van subgroepen van informanten divergeren.

Het navolgende schema geeft de opzet van het onderzoek weer.

Schema 2: Een grafische voorstelling van het onderzoek

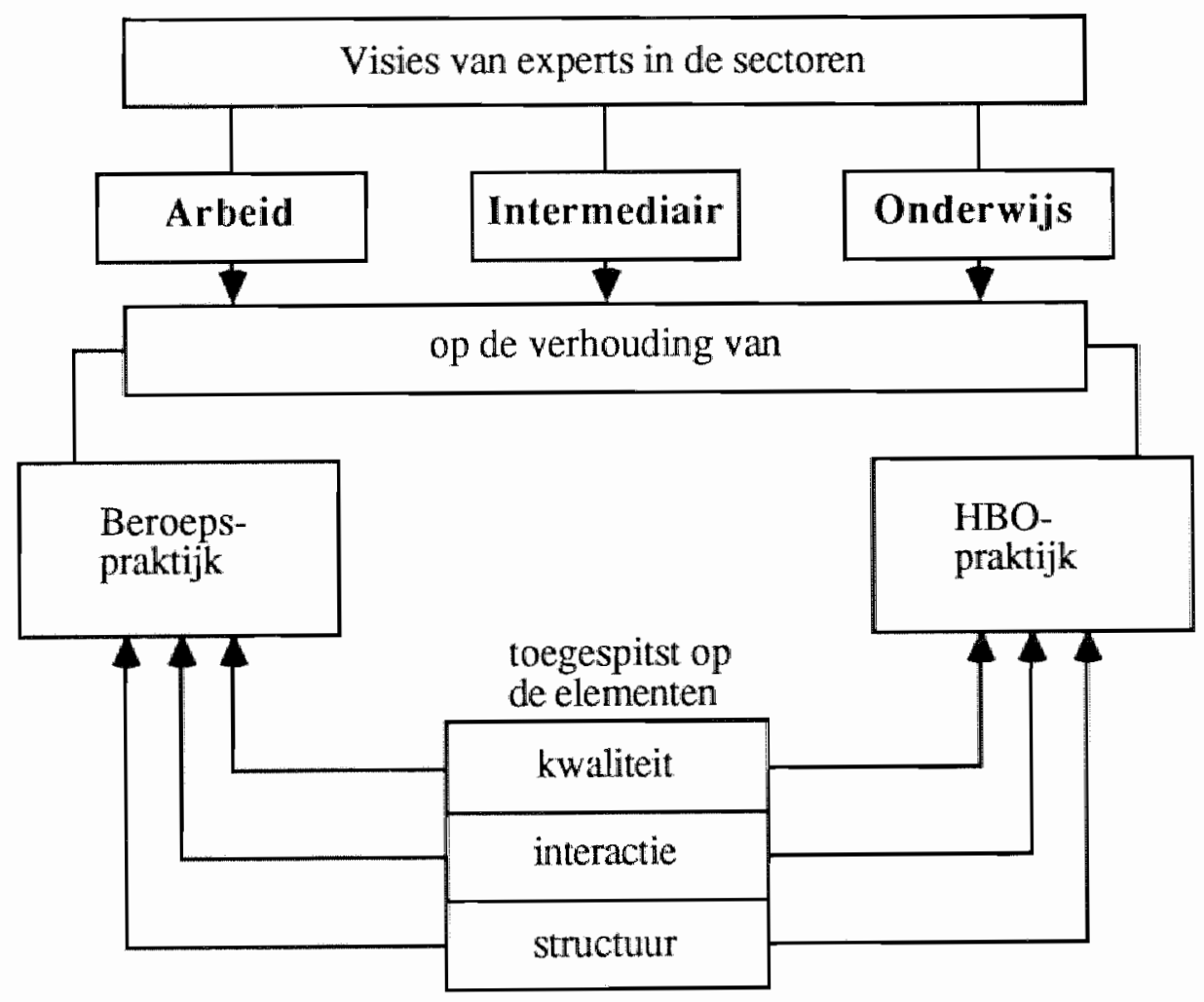


Wij schetsen in de hoofdstukken $3 \mathrm{t} / \mathrm{m} 5$ een aantal visies op relevante aspecten van het HBO. Daarnit blijkt dat er bezwaarlijk sprake kan zajn wan één uniforme visie. Integendeel, de meningen divergeren; tal van aspecten zijn op uiteenlopende wijze te beschouwen en te beoordelen. Dat is niet verwonderlijk. Onderwijs is een maatschappelijke institutie die op zichzelf al voorwerp van verandering en politieke en maatschappelijke discussie is. Daarnaast lijkt - gegeven de geschetste spanningsmomenten - een cruciale factor vanuit welke positie men over beroepsonderwijs oordeelt. Het is aannemelijk dat personen uit de beroepspraktijk andere visies hebben dan mensen in de onderwijssector. A fortion geldt dit voor een vorm van onderwijs die op de arbeidssector is gericht en daarmee ook in wisselwerking staat.

In hoofdstuk 1 stelden wij vast dat het tot dusver bekende aansluitingsonderzoek sterk is verlopen conform het zogeheten Robinsohn- en het Communicatiemodel. Te weinig is tot dusver uitgegaan van het kwalificatiebegrip (het geheel van kennis, houdingen en vaardigheden dat mensen in staat stelt arbeidsprestaties te verrichten). Een schets van functies van het $\mathrm{HBO}$ en visies op relevante aspecten van het onderwijs dient ertoe de gedachten nader te bepalen. In relatie tot het doel van deze studie komen aspecten als het rendement, de maatschappelijke rol en de structuurvernieuwing van het HBO nader aan de orde (vgl. par. 2.3). Wij kunnen het volgende vaststellen:

- de verwarring rond begrippen en de divergenties in visies op taken, functies en structuur van het $\mathrm{HBO}$, kan op zichzelf een complicerende factor zijn bij overleg van partijen en de verdere ontwikkeling van toekomstgericht beleid.

- indien wij uitgaan van de aspecten kwaliteit, interactie en structuur van het $\mathrm{HBO}$ is het mogelijk via deze kernbegrippen enige ordening aan te brengen in visies op relevante aspecten.

Deze drie begrippen zijn in hun onderlinge samenhang verder uitgewerkt in de volgende paragraaf.

\subsubsection{Kwaliteit, interactie en structuur}

De keuze voor de drie elementen "kwaliteit, interactie en structuur" werd ingegeven door de resultaten van een eerder verricht, verkennend onderzoek (vgl. Frederix, 1978) naar visies op de relatie van onderwijs- en arbeidsmarkt. 
De bedoelde studie was niet specifiek gericht op visies met betrekking tot het $\mathrm{HBO}$ maar bracht in kaart hoe de verhouding van beroepsonderwijs en arbeidsmarkt werd beoordeeld. In dit kader werden 402 informanten uit het onderwijs, de arbeidsorganisaties en het intermediaire circuit benaderd.

De centrale vraag was hoe mensen oordeelden over enkele aspecten van aansluitingsproblemen van onderwijs en beroepspraktijk en welke essentiële verschillen in deze beoordeling optraden. Met name de vraag naar de mate van afhankelijkheid van het onderwijs ten opzichte van de beroepspraktijk is daarin onderzocht. Uit (factor)analyse op de respons (van 332 informanten) bleken de bovengenoemde elementen kwaliteit en interactie duidelijk naar voren te komen.

Het leek van belang deze elementen te gerelateerd aan het HBO te onderzoeken. Het element structuur werd toegevoegd, gelet op het belang en de implicaties van de discussies over vormgeving en inbedding van het HBO. Wij gaan daarbij uit van de assumptie dat structuur- en organisatie-ontwikkelingen niet alleen worden ingegeven door overwegingen met betrekking tot kwaliteit en interactie maar voor deze aspecten van het HBO ook consequenties hebben als organisatie en instituut in zijn omgeving en in de samenleving. Dit onderzoek vertrekt vanuit de aanname dat in de beoordeling door mensen van de relatie van het $\mathrm{HBO}$ met de beroepspraktijk tussen visies op kwaliteit, interactie en structuur samenhang bestaat. Voor wij op deze samenhang nader ingaan, kan het volgende worden opgemerkt:

- de drie aspecten vormen spanningsmomenten in de relatie tussen onderwijs en arbeid (vgl. SER-nota 1981),

- discussies en standpuntbepalingen ten aanzien van de drie aspecten vinden zowel plaats in de sectoren arbeid en onderwijs, als in intermediaire organisaties,

- divergenties in visies ten aanzien van deze aspecten lijken gekoppeld aan verschillen in positie van mensen die hun visie geven. Uit het verschil in positie volgt een verschil in waardering en beoordeling van cruciale aspecten (vgl. Frederix, 1978),

- de aspecten zajn - gelet op de veelheid van discussies en publikaties daaromtrent - kennelijk kernelementen inzake de toekomstige ontwikkeling van het HBO (vgl. Mc Daniel, 1984).

Op elementen en hun onderlinge samenhang wordt onderstaand ingegaan. 


\subsubsection{Kwaliteits-aspecten}

Dit aspect vormt voor ons het vertrekpunt. Daarbij is de vraag aan de orde naar de visies op kwaliteit van onderwijs-opbrengst. Op welke elementen van het functioneren in de beroepspraktijk, moet het $\mathrm{HBO}$ in zijn beroepswoorbereidende taak vooral letten, zo luidt de vraag. Nu is deze vraag zowel breed qua strekking als omstreden qua beantwoording. Beoordelingen van kwaliteit van onderwijsresultaat hangen kennelijk samen met visie op de vervulling van functies van het onderwijs. De grote werkloosheid onder jongeren en schoolverlaters b.v. zou te wijten zijn aan het feit dat het onderwijs niet de juiste kwalificaties overbrengt (er wordt dan bijvoorbeeld gezegd dat het onderwijs achter de ontwikkelingen aanloopt); de kwalitatieve discrepanties tussen vraag en aanbod en de klachten over het functioneren van schoolverlaters in de werksituatie zouden toegeschreven moeten worden aan de onvoldoende overdracht van kwalificaties. Dit onderscheid wordt door Van Hoof en Dronkers (1980: p.32) nader gedefinieerd als kwantitatieve versus kwalitatieve aansluitingsproblematiek:

\section{- kwantitatieve aansluitingsproblematiek:}

"... slaat op discrepantie bij de allocatie van kwalificaties: het gaat dan om discrepanties op de arbeidsmarkt tussen aangeboden en gevraagde kwalificaties";

\section{- kwalitatieve aansluitingsproblematiek:}

"... slaat op discrepanties bij de benutting van kwalificaties; het gaat dan om discrepanties tussen beschikbare en vereiste kwalificaties".

Wij volstaan met de opmerking dat een studie naar de beoordeling en opvattingen over de onderwijsopbrengst kennelijk niet voorbij kan gaan aan dit onderscheid: zowel vereiste en gevraagde kwalificaties als aangeboden en beschikbare kwalificaties zijn geen synoniemen (cf. Van Hoof en Dronkers, 1980). De kwalitatieve discrepanties die kunnen optreden tussen hetgeen het onderwijs als opbrengst heeft en hetgeen de markt vraagt kunnen van velerlei aard zijn. Onderscheid wordt hier gemaakt in kwalitatieve discrepantie naar niveau, naar studierichting en naar programma (vgl. SER-nota 1981). Indien wij nagaan hoe deze kwalitatieve aansluiting wordt beoordeeld, wordt duidelijk welke verschillende typen van beoordeling en normering aan de orde kunnen zijn. Verschillen kunnen ontstaan uit het feit dat de mensen in de verschillende kaders (het onderwijsbestel, het arbeidsbestel) ten aanzien van de rol van het onderwijs en - als gevolg daarvan - ten aanzien van de aansluiting van onderwijs en arbeid verschillende opvattingen hebben. 
De dimensies van de kwalitatieve aanshitingsproblematiek worden bezien vanuit het arbeidsproces, onder andere bepaald door opleidingsniveau en -richting, regio's, sectoren en bedrijfstakken. Vanuit het onderwijs treedt een zeker naijleffect op, plus hel gegeven dat onderwijs meer taken vervult dan de concrete voorbereiding op een beroep. Vanuit de invalshoek van het overheidsbeleid kan de beheersbaarheid en de bestumbaarheid van de vraagzijde ten opzichte van de aanbodzijde een probleem vormen (vgl. SER-nota 1981).

De vraag is nu welke visies informanten met uiteenlopende achtergronden en verschillende posities bebben op de ontwikkeling van $\mathrm{HBO}$-output in de toekomst en hoe zij het belang van essentielle kwalificatie-aspecten met het oog op die toekomst waarderen. Uit de bovenstaande schets volgt de relevantie van het reeds eerder aangegeven onderscheid in partijen die het onderwerp van onderzoek op verschillende wijzen kunnen beoordelen. Gelet op de verschillen in taak en positie, tussen onderwijs en arbeid, ligt een verschil in visies voor de hand. Dit verschil in positie van relevante partijen ten opzichte van het probleem levert een tweede bron van potentiële spanning én een tweede aspeet van onderzoek op. Wij hebben dit aangeduid met de term Interactie.

\subsubsection{Interactie-aspecten}

De aansluiting van onderwijs en beroepspraktijk is niet slechts een methodisch - kwaliteits - probleem, samengevat in de vraag "hoe krijgt het onderwijs zijn leerlingen en studenten zo goed mogelijk gekwalificeerd", maar ook een principieel probleem. Waar ligt de grens tussen wat onderwijs mag en kan doen en wat het arbeidsbestel derhalve nog moet doen?

Daarnaast kan de oplossing van de spanning tussen onderwijs en arbeid niet van één kant komen, gelet op de aard en de kwaliteit van de beroepspraktijk. Die beroepspraktijk is geen statisch gegeven, zij evolueert en de richting van de evolutie is weinig duidelijk. Het onderwijssysteem is echter statischer, reageert trager op veranderingen en kan de hoge investeringen, nodig om elke fluctuatie van de beroepspraktijk in het arbeidsbestel onmiddellijk te volgen, niet aan (vgl. Parkes e.a., 1986). Bij het in kaart brengen van visies op de relatie onderwijs-arbeidsmarkt leek het van belang ook de beïnvloeding over en weer van het arbeidsbestel en het onderwijsbestel te verkennen en de visies daarop te onderzoeken. Binnen het onderwijs is, met bet oog op het maatschappelijk functioneren van de school in de toekomst, gestreefd naar explicitering van eigen doelstellingen persoonlijke ontplooïng, algemeen maatschappelijke voorbereiding en ( $\mathrm{min}$ of meer specifieke) beroepsvoorbereiding. Wat de ontwikkeling van doelstellingen aan de sociaal-economische kant 
betreft, kan in dit verband (met inachtneming van de factoren die voor elke werkorganisatie afzonderlijk kunnen variëren) worden gewezen op de formulering van doelstellingen van nationaal-economisch beleid als belangrijk kader voor ontwikkeling. De vraag naar (de mate van) verenigbaarheid van onderwijsen sociaal- economische doelstellingen heeft een theoretisch aspect en een praktisch aspect. Dat laatste theeft te maken met de vraag of een optimaal interactie- en relatiepatroon tussen onderwijs en arbeidsbestel dichterbij kan worden gebracht. Gegeven de onderwijsinhoudelijke verschuiving van beroepsonderwijs naar algemeen vormend onderwijs is dit (nog) niet het geval. Deze brede basis zou een betere garantie zijn voor weerbaarheid en wendbaarheid op de arbeidsmarkt en in het arbeidsbestel, vooral op de langere termijn (vgl. SER-nota, 1981, p. 32 e.v.).

De ontwikkelingen in het arbeidsproces beantwoorden tot nu toe echter niet aan dat beeld. De vraagzijde blijft kennelijk een groter accent leggen op beroepsgerichte vaardigheden en bekwaamheden dan het onderwijs aflevert.

Dit verklaart waarom scholieren met een opleiding waarin algemeen vormende elementen overheersen over het algemeen een slechtere arbeidsmarktpositie hebben (vgl. SER-nota, 1981, p. 33).

De uiteenlopende doelstellingen van beleid, het verschil in beleidskaders en het verschil in doelstelling en karakter van onderwijsinstellingen en beroepspraktijken kunnen de discussie over de aansluiting van onderwijs en beroepspraktijk polymorf maken en tot misverstanden aanleiding geven.

Het feil dat er sprake is van een duidelijke wisselwerking tussen de systemen onderwijs en arbeid en dat de wisselwerking van invloed kan zijn op zowel wederzijdse beoordeling als op visies over kwaliteit, bracht ons ertoe ook dit aspect in het onderzoek te betrekken. Wij onderscheiden de relatie tussen onderwijs en arbeid op drie niveaus (vgl. De Keulenaar e.a., 1984).

- Het eerste niveau is dat van de relatie tussen onderwijsbestel en arbeidsbestel. Het is het veld, waarin politieke keuzes moeten worden gedaan als die rondom de mate van afstemming tussen onderwijsdoelstellingen en sociaal-economische doelstellingen.

Vraagstellingen en probleemgebieden op terreinen als volledige werkgelegenheid, deeltijdarbeid, emancipatie, educatief verlof, duur van de leerplicht, drempelloze toelating tot onderwijsvoorzieningen, onderwijs als instituut van educatie, gericht op persoonlijke ontplooiing en/of onderwijs als instituut van allocatie, gericht op toelevering van geschikte mensen aan de "eigenlijke" maatschappij, vinden in dit gebied eveneens hun plaats.

- Het tweede niveau is dat van de relatie tussen onderwijs en arbeidsmarkt. Hier gaat het om de verhouding tussen vraag en aanbod en om de mecha- 
nismen, die daarbij een rol spelen, zowel de in de arbeidsmarkt werkzame mechanismen als absorptie en verdringing als de in het onderwijs werkzame mechanismen als selectie, determinatie en klassering of deklassering.

- Het derde niveau is dat van de relatie tussen onderwijs en beroepspraktijk, dat tussen onderwijs en de dagelijkse werkelijkheid van de beroepsuitoefening. De vraagstelling hier is: hoe kunnen beide het best op elkaar worden afgestemd?

Deze drie niveaus zijn weliswaar te onderscheiden, maar zij hangen ook ten nauwste samen. Wij zullen ons beperken tot het laatste en meest concrete gebied en ons de vraag stellen naar de mate waarin in dit veld de spanning tussen onderwijs en arbeid zou kunnen worden verminderd. Daartoe zijn visies op de interactie van onderwijs en arbeid verkend en aan informanten voorgelegd. De combinatie van kwaliteit en interactie is gelegd op grond van eerder verricht onderzoek (vgl. Frederix, 1978) en vanuit de aanname dat voor informanten (vanuit verschillende posities betrokken bij de aansluiting van HBO en beroepspraktijk) zowel de kwaliteit als resultaat (als outputkenmerk) als de kwaliteit wan de relatie van onderwijs en arbeid op zich en in hun onderlinge samenhang, relevant zullen zijn bij het bepalen van visies op het toekomstig HBO.

Het derde aspect betreft het thema "structuur en organisatie van het HBO in de toekomst".

\subsubsection{Structuur-en organisatie-aspecten}

Het onderwijs als institutie - en met name het $\mathrm{HBO}$ - is voorwerp van structuurwijzigingen en veranderingen qua organisatie. Deze veranderingen vinden plaats na uitgebreide discussies waarin tal van -- divergente - visies tot ontwikkeling komen. Deze appreciaties van nieuwe structuren kunnen variëren met de posities van de afzonderlijke categorieën van beoordelaars zoals eerder weergegeven. Ervan uitgaande dat structuren geen dwingend handelingskader vormen, maar de ruimte bieden veranderingen aan te brengen, ligt het voor de hand dat men bij de bestudering van de rellatie $H B O$ en beroepspraktijk rekening houdt met ontwikkelingen in de structuur en de organisatie van het $\mathrm{HBO}$.

Aan aspecten die samenhangen met veranderingen in de structuur en organisatie ontbreekt het niet. Wij zullen ons in het kader van deze studie niet richten op thema's als schaalvergroting en concentratie maar trachten toekomsttrends in kaart te brengen die zich naar de visies van diverse auteurs in de komende jaren zullen aftekenen. 
Ook ten aanzien van dit aspect kunnen mensen met een verschillende positie uiteenlopende visies hebben op de ontwikkeling van het $\mathrm{HBO}$ in de toekoust. Onze vraag is hoe de samenhang met visies op de andere geschetste aspecten (kwaliteit - interactie) is en langs welke lijnen de beoordeling van de drie aspecten - in combinatie met elkaar - plaatsvindt (voor een uitgebreide beschrijving van dit element wordt verwezen naar Frederix, 1978).

\subsubsection{Samenvatting van de hoofdpunten}

De hoofdpunten van het onderzoek worden gevormd door:

- een onderzoek naar de visies op kwaliteitsgebieden waarop onderwijs - pbrengst op HBO-niveau in de toekomst gestalte zou moeten krijgen;

- de beoordeling van de gewenste interactie, (de openheid van een school voor de beroepspraktijk en vice versa) in de toekomst;

- de bepaling van de wenselijkheid die aan ontwikkelingen op enkele hoofdpunten van het HBO qua organisatie en qua structuur wordt toegekend.

Centrale vraag is welke visies informanten hebben op deze facetten van de verhouding van het $\mathrm{HBO}$ en de beroepspraktijk. Met het peilen van visies op de toekomst van het HBO lijkt tevens een punt van kritiek, zoals deze door Vlaskamp en Hövels is verwoord op de twee tot dusver gangbare kaders voor onderzoek van de relatie van onderwijs- en arbeidssector, aangegrepen (vgl. Vlaskamp en Hövels, 1980).

Wij ronden dit hoofdstuk af met een beschouwing van relevante aspecten van het $\mathrm{HBO}$, meer bepaald ten aanzien wan het thema beroepskwalificatie.

\subsection{ENKELE RELEVANTE ASPECTEN NADER UTTGEWERKT}

\subsubsection{Visies op functies van het $\mathrm{HBO}$}

Het vertrekpunt van onze analyse wordt gevormd door een verkenning van de functies van het $\mathrm{HBO}$. Op de explicitering van deze functies en de centrale plaats van beroepskwalificatie volgt een nadere beschouwing van actuele en uiteenlopende visies op de posities en rollen van het $\mathrm{HBO}$.

Een schets van visies op functies van het HBO illustreert hoe uiteenlopend de stellingnames kunnen zijn. Het denken over het $\mathrm{HBO}$ in relatie tot de beroepspraktijk hangt naww samen met de functies die het HBO zou moeten vervullen. Deze functie is als drieledig op te vatten: (cf. van Wieringen, 1976) 
- de overdracht van kwalificaties/het bieden van een voorbereiding op beroepen op hoger niveau;

- bet bieden van een onderwijsweg aan specifieke groepen studenten die elders geen mogelijkheden vinden;

- het vervullen van een toeleveringsfunctie voor het wetenschappelijk onderwijs (de evolutie van eindopleiding naar vooropleiding).

De overdracht van beroepskwalificaties (de voorbereiding op beroepen) geldt als de centrale functie van het $\mathrm{HBO}$. Een tweede functie lijkt het bieden van een onderwijsweg voor groepen studenten, die elders, bijvoorbeeld aan een universiteit, (nog) geen mogelijkheden hebben. (van Wieringen, 1976, p. 92 e.v.). Deze functies staan niet los van elkaar. Immers, de doelstelling beroepsopleiding te zijn en de vormgeving om deze doelstelling te bereiken maakten het mogelijk dat andere studenten werden aangetrokken die elders geen plaats vonden. In zekere zin fungeert het Hoger Beroepsonderwijs niet alleen als een tegenhanger van het algemeen onderwijs (inclusief het wetenschappelijk onderwijs), maar ook als een correctie op de tekortkomingen daarvan. Van Wieringen acht een van de kenmerken van het $\mathrm{HBO}$, dat het ontstaan is binnen de sociaal minder geziene tak van het dualistische schoolwezen. Als zodanig liggen binnen die tak ook de grootste verantwoordelijkheden. Met name om een principe als doorstroming te verwezenlijken is een beleid, gericht op zo goed mogelijke samenhang met het $\mathrm{MBO}$ en het onderwijs aan werkende jongeren, een voorwaarde. Maar de andere tak van het schoolwezen heeft altijd een bijzondere aantrekkingskracht uitgeoefend. De universiteiten genieten een hoog prestige, een grote mate van autonomie. Een verdergaand inzicht in de problematiek van de identiteit van het $\mathrm{HBO}$ kan, volgens van Wieringen, worden gewonnen door een studie van de problematiek van de beroepen, waarvoor het Hoger Beroepsonderwijs een opleiding geeft en door een vergelijkende studie van het Hoger Beroepsonderwijs op zichzelf.

De discussie over de verhouding van het $\mathrm{HBO}$ en het arbeidssysteem wordt gekenmerkt door het feit dat de eerste functie een opvallende plaats inneemt. Het is dan ook deze functie die door ons als uitgangspunt wordt gekozen in de studie naar de visies van de relevante actores. Daarmee is niet gezegd dat de beide andere functies geen rol zouden spelen in de visies op de relatie van $\mathrm{HBO}$ en beroepspraktijk. $\mathrm{Zij}$ hangen echter nauw samen met de eerste functie en de aandacht van het arbeidssysteem zal in eerste instantie gericht zijn op effectieve output. Daarvoor zijn twee redenen aan te geven:

- dat specifieke groepen studenten het HBO kiezen omdat de doelstelling en de vormgeving van het $\mathrm{HBO}$ een alternatief vormen op de tekortkomingen 
van het algemeen onderwijs speelt in de beoordeling van de aangeboden kwalificaties geen rol van betekenis.

- dat het HBO naast het overbrengen van kwalificaties ook tot vooropleiding "evolueert" voor het WO kan een spanningsbron vormen, zeker in die gevallen waar studenten kiezen voor een "vooropleiding" en dientengevolge op de arbeidsmarkt een vraagoverschot ontstaat in bepaalde sectoren. Maar juist in die gevallen zal het HBO verweten worden zich niet te houden aan de eigenlijke doelstelling: het voorbereiden op een beroep (cf. H.O.A.K.-nota, 1985).

Het begrip kwalificatie vervult aldus een sleutelrol in de discussie over en tussen HBO en beroepspraktijk. Aan dit begrip wordt in deze studie de functie van het $\mathrm{HBO}$ gekoppeld. De beoordeling van het $\mathrm{HBO}$, wordt vervat in termen van rendement. Dit rendementsbegrip wordt vanuit het HBO ingevuld met verwijzing naar de socialiserende werking van het onderwijs. De beroepspraktijk daarentegen zal rendement meer zien in termen van juiste en voldoende kwalificaties met het oog op allocatie naar bruikbaarheid en inzetbaarheid.

Centraal in de discussie staat het eerdergenoemde begrip kwalificatie (vgl. par. 1.3), opgevat als de toerusting voor de beroepspraktijk. Dit begrip wordt vervat in termen van kwaliteit waaraan een $\mathrm{HBO}$-abituriënt zou moeten voldoen, daarmee verwijzend naar een binnen het onderwijs verworven set van kwalificaties. Op deze toeleverende rol van het $\mathrm{HBO}$ en het aspect beroepskwalificatie gaat deze studie in. Het vertrekpunt ligt bij de discussie over de in de toekomst wenselijk geachte verhouding van onderwijspraktijk en beroepspraktijk.

\subsubsection{Beroepskwalificatie als doel van het $H B O$}

Voor de definiëring van "beroep" sluiten we aan bij van Wieringen (1976, p. 102) "een geheel van kwalificaties die veelal door een systematische opleiding zijn verworven ter uitvoering van zekere werkzaamheden". Deze definitie geeft aan dat het niet enkel gaat om het ontstaan maar ook om de instandhouding en het feitelijk functioneren in beroepen, waarbij onderwijs een rol van betekenis speelt. Essentieel voor van van Wieringen is, dat bepaalde kwalificaties een potentie tot beroepsvorming hebben, waarbij de functie van deze kwalificaties "het paspoort op de arbeidsmarkt" is.

Verder is er sprake van een hoge mate van overeenstemming van verwachtingen tussen gebruikers van deze kwalificaties en werkenden met betrekking 
tot de te leveren prestaties en de aan te bieden arbeidsvoorwaarden. Er is dus sprake van een zekere certificatie én her vermogen tot beroepsvorming. De potentie tot beroepsvorming komt ook voort uit de formalisering en de publieke erkenning van de opleiding, die gericht is op de beoogde kwalificaties. De vraag wordt hier dus niet meer wat vereist een bepaald beroep aan kwalificaties, maar welke kwalificaties zijn op welke plaatsen te gebruiken en wanneer vormen ze in cen bepaalde combinatie een geheel, dat een beroep wordt genoemd?

Beroepen, als verzamelingen van kwalificaties blijven in deze zin een belangrijke positie innemen in het functioneren van de arbeidsmarkt en in de oriëntatie van het onderwijs op die markt. In de visie van van Wieringen wordt het kwalificatiebegrip zo opgevat, dat de gerichtheid op maatschappelijke rationaliteit er een wezenlijk onderdeel van is. Daarbij komt volgens hem de vraag naar het beroepsgerichte karakter van het beroepsonderwijs in een ander licht te staan. Niet zozeer bet begrip beroep op zichzelf is richtsnoer voor het onderwijs, als wel de onderscheiden kwalificaties die in een bepaalde combinatie een beroep uitmaken.

Bij deze invulling van het kwalificatiebegrip staat niet alleen de te leveren arbeidsprestatie centraal, maar ook de geschiktheid om de arbeidssituatie zodanig te helpen vormen dat een optimaal gebruik wordt gemaakt van deze kwalificaties en dat impulsen aanwezig zijn voor verdere ontplooiing.

Een dergelijke benadering is wezenlijk voor het beroepsonderwijs. "In deze zin is het begrip "beroep" een zinvol richtsnoer voor het beroepsonderwijs", aldus van Wieringen. Hij acht niet het beroep in enge zin, maar veel meer het geheel van te onderscheiden kwalificaties in combinatie met elkaar een richtsnoer voor onderwijs. Het gaat in zijn visie ook om het vermogen van de werker actief in de arbeidssituatie in te grijpen, deze mede te helpen vormen en daarin die nieuwe impulsen aan te brengen en te ontdekken, die nodig zijn voor verdere ontplooiing. De specifieke functie van het beroepsonderwijs is dus niet alleen het aanbrengen van kwalificaties, maar ook het ontwikkelen van het vermogen bij de leerling om in de arbeidssituatie met deze kwalificaties actief en vormend om te gaan en op de omgeving ingrijpend te werken. Volgens van Wieringen is de veronderstelling gewettigd, dat onderwijs meewerkt aan processen, welke resulteren in de vorming van een beroep. (van Wieringen 1976, p. 106 e.v.)

Centraal in de redenering is de actieve en stimulerende abituriënt die door het onderwijs ook op dit punt van kwalificaties is voorzien ten behoeve van en functionerend in de beroepspraktijk. Als beroepsbezigheden veelzijdiger en stimulerender vorm kunnen krijgen, kunnen ook onderwijskundig twee doelstel- 
lingen worden bereikt: gekwalificeerde en zelfstandige werkers maken een betere opleiding en een verdere studie niet alleen zinvol, maar ook noodzakelijk. Op de tweede plaats wordt aan "professionals" niet alleen een sterke prikkel tot leren geboden, maar worden ook reële leermogelijkheden geboden. De beroepservaring die iemand opdoet wordt onderdeel van zijn persoonlijke ontplooiing. De wisselwerking tussen de ontplooïng van mensen en de benutting van deze ontplooiing in het werken betekent een ruimere opgave voor het beroepsonderwijs en ook voor het scholen "on the job" door bedrijven.

Het beroepsonderwijs houdt thans daar op waar het beroep qua uitoefening begint, terwijl in deze opvatting onderwijs zich deels ook verantwoordelijk zou moeten achten voor de benutting van kwalificaties en nieuwe mogelijkheden tot ontplooiing in de beroepspraktijk. Deze manier van denken leidt ook tot de vraag naar de mate van wisselwerking, van aanvulling en van vervanging die verschillende vormen van leren ten opzichte van elkaar hebben. Als centraal element geldt het aanbieden van kwalificaties. Deze leveren een pakket aan vaardigheden op waarmee de werker in de praktijk tot concreet functioneren en tot feitelijke verandering en vernieuwing van deze praktijk kan komen.

\subsubsection{Het verschil in kaders}

De kaders voor het verwerven én het gebruiken van kwalificaties zijn echter onderscheiden. De verantwoordelijkheid van de school houdt veelal feitelijk op bij de eindcertificatie, de afsluiting van de opleiding. Het kader waarin abituriënten daarna functioneren, verschilt fundamenteel van wat de school betekende. De primaire oogmerken verschillen aanzienlijk; het onderwijs heeft vorming en ontplooiing als doel, in de beroepspraktijk tellen primair produktie en prestatie.

Dat verschil in oriëntaties en kaders (voor het divergeren van visies uit onderwijs c.q. beroepspraktijk van belang) was voor ons aanleiding drie partijen te raadplegen.

$\mathrm{Na}$ de bovenstaande schets van functies van het $\mathrm{HBO}$ wordt in de volgende hoofdstukken een overzicht gepresenteerd van visies met betrekking tot de drie hoofdaspecten, zoals relevant geacht bij het beoordelen van de relatie van HBO en beroepspraktijk. De drie centrale elementen van het onderzoek werden nader beschouwd tegen de achtergrond van de actualiteit van de discussies. Wij zullen bij de bespreking van de visies achtereenvolgens aandacht schenken aan: 
- kwaliteitsaspecten en het rendement van onderwijs (hoofdstuk 3)

- interactie-aspecten en de maatschappelijke rol van het onderwijs (hoofdstuk 4)

- structuur- en organisatie-aspecten en de toekomst van het HBO (boofdstuk 5).

\subsection{TOT BESLUTT}

In dit hoofdstuk is de bedoeling van deze studie geformuleerd, werd het theoretisch kader geschetst en zijn enige aspecten van de relatie tussen onderwijs en arbeid beschreven. Dit is gedaan om de breedte van de discussie te illustreren én om een conceptueel kader te creëren teneinde dimensies in het oordeel van experts met betrekking tot deze relatie nader te kunnen onderzoeken.

De drie hoofdelementen van het onderzoek zijn gedefinieerd en -- voorlopig verkend in hun onderlinge samenhang. Het hoofdstuk is besloten met een beknopte schets van functies van het $\mathrm{HBO}$ en een formulering van de verschillen tussen de kaders onderwijs en arbeid. 


\section{Kwaliteitsaspecten}

\subsection{INLEIDING}

Vanuit een korte schets van benaderingen van het rendement van onderwijs wordt de achtergrond aangegeven van het denken over kwaliteit in meer specifieke zin. Wij gaan daarbij in op de onderscheiden visies op rendement en de relatie met de in hoofdstuk 1 geschetste spanningsbronnen tussen onderwijs en arbeid (par. 3.2). Daarna komt het kwalificatiebegrip aan de orde. Wij schetsen enkele divergente visies en komen tot een eerste operationalisering van kwaliteits-aspecten (par. 3.3 e.v.).

\subsection{VISIES OP RENDEMENT VAN ONDERWISS}

Een belangrijk aspect in de beoordeling van het onderwijs als systeem lijkt het rendement ervan te zijn. Wielemans (1983) volgend kan men stellen dat het denken over rendement, (als de afweging tussen investeringen in en opbrengst van het onderwijs) relatief nieuw is in de pedagogische wetenschappen. Het ontbreken van duidelijke doelstellingen als standaard voor evaluatie maakt beoordeling van de HBO-output zijns inziens echter telkens tot een min of meer subjectieve aangelegenheid. Ook in het denken over rendement van het onderwijs in het algemeen bestaan uiteenlopende benaderingswijzen. Enkele ervan zullen wij, ter illustratie wan het geheel aan divergente visies, kort schetsen.

\section{- De "human capital" benadering}

Centraal in de "human capital" benadering staat de gedachte dat onderwijs een vorm van investeren in mensen is. Een investering die bijdraagt tot de toename van het persoonlijk inkomen en (mutatis mutandis) zorgt voor de economische groei van het land. Het accent van de theorie ligt op het utilistische concept van kosten en baten. 


\section{- De "rest-groorte" benadering}

De constatering dat de traditionele economische factoren (arbeid, kapitaal en grond) de economische groei onvoldoende konden verklaren, vestigde de aandlacht op een "restfactor". Onderwijs kwam daarbij in de belangstelling te staan omdat bij de verklaring van de economische groei niet alleen rekening moest worden gehouden met de kwantitatieve toename van de produktiefactoren, maar ook met de kwalitatieve toename. Naarmate het onderwijs meer is afgestemd op de arbeidsmarkt zal het effect van onderwijs op de economische groei groter zijn.

\section{- De "manpower" benadering}

Deze benadering gaat uit van een kwantitatieve samenhang tussen onderwijs en het economisch systeem. Dit idee stimuleerde enerzijds de onderwijsplanning (planning op basis van kwantitatieve relaties tussen beroepsprofielen en opleiding) en anderzijds de leerplanontwikkeling (afstemming van beroepsprofiel en opleiding door middel van didactische modellen). Nadeel van deze benadering is dat door de pre-occupatie met het economische nut geen recht wordt gedaan aan sociaal politieke en immateriële onderwijsdoelen.

\section{- De "output" benadering}

Onderwijs wordt in deze gedachtengang gezien als een gereed eindprodukt. De school geldt als produktiesysteem waarbij de output wordt beoordeeld naar de mate waarin de onderwijsdoelstellingen naar eigen maatstaven zijn gerealiseerd. Ritzen (1983) bekritiseert de input/output studies op de eenzijdigheid van hun outputindicatoren en de vaagheid van de onderwijsdoelstellingen.

Vooral voor de eerste drie benaderingen is de pre-occupatie met het economisch nut kenmerkend. Een utilistische benadering is te eenzijdig en doet geen recht aan sociaal-politieke factoren in de onderwijsdoelstellingen. Wij geven de voorkeur aan een rendementsbegrip opgevat als feitelijk (gepercipieerd) resultaat van onderwijs gezien zowel vanuit de arbeidsmarkt als de arbeidsorganisatie. De beoordeling van het rendement in de arbeidsorganisaties zal zich - zo wordt verwacht - in eerste instantie richten op de allocatie en benutting van kwalificaties. Mensen in het onderwijs daarentegen zullen zich niet alleen laten leiden door allocatie en/of benutting van kwalificaties, maar de bredere maatschappelijke onderwijsdoelstellingen in hun oordeel zwaarder laten wegen.

Gelet op de door Hövels geschetste spanningsmomenten kan dit verschil in uitgangspunt tot verschillen in visies leiden. Zowel de structureel-technische spanningsbron als de structureel-distributieve spanningsbron (cf. Hövels 1984) 
kunnen relevante factoren zijn bij het oordelen over het rendement van onderwijs in het algemeen (Voor een meer vitvoerige analyse wordt verwezen naar Frederix, 1978).

Het antwoord op de wraag naar het rendement van het onderwijs is mede afhankelijk van de gerichtheid van het $\mathrm{HBO}$ op de beroepspraktijk en de breedte van de beroepsvoorbereiding. Immers, in de beroepspraktijk moet een belangrijk deel van de inspanning en investering binnen het onderwijs effectief worden gemaakt. Het moge zo zijn dat het HBO meerzijdig inzetbare en breed opgeleide abituriënten opleidt, toch blijft elke HBO-opleiding op een sector, een segment van menselijke bedrijvigheid gericht. Technisch geschoolde schoolverlaters bijvoorbeeld hebben doorgaans een andere beroepswens, een anders gerichte vooropleiding en een anders gerichte belangstelling en studiekeuzemotieven dan studenten aan een Sociale Academie. De opleiding wordt gekozen op grond van velerlei motieven maar het perspectief van de beroepspraktijk is een factor die de keuze voor een concrete opleiding mede lijkt te bepalen. Het HBO leidt niet op voor een bepaalde functie in deze of gene organisatie of instelling. "Het bereidt" - aldus de HBO-Raad in de beleidsnota "Versterking door samenwerking" (1983, p. 87) - "studenten voor op bepaalde typen van maatschappelijke activiteiten in de beroepsmatige sfeer".

Dat is een opgave die verder strekt dan smalle functietraining, ze is mede gericht op het aanleren van flexibiliteit bij de studenten om op nieuwe ontwikkelingen adequaat te reageren.

Het lijkt overigens of er meer kritiek op de opbrengst, het rendement van het onderwijs is. Zo maakt b.v. Ritzen (1983) gewag van een "onderwijsperformance-crisis". Ritzen denkt dat de verwachtingen ten aanzien van de sociaal-economische betekenis van de expansie van het onderwijs, daterend uit de jaren vijftig en zestig, niet vervuld zijn. In sociaal-economische zin heeft het onderwijs in het afgelopen decennium "gefaald". Slechts in beperkte mate speelde het onderwijs tot nu toe een rol bij de gewenste vernieuwing van de industriële structuur. (Ritzen 1983, 139 e.v.). Hij acht het bestaan van deze "performance-crisis" van belang in verband met het begrijpen en verklaren van tal wan onderwijs-annexe problemen. Volgens Ritzen is "het falen van het onderwijs als instrument voor de sociaal-economische ontwikkeling eerder terug te voeren op een zich verwijderen van de "onderwijscultuur" van de "cultuur in de commerciële marktsector", (1983, p. 143), dan tot concrete maatregelen zoals b.v. het aantal uren algemeen vormende vakken in het lager beroepsonderwijs.

De bovenstaand weergegeven ideeën met betrekking tot het rendement van onderwijs illustreren de pluriformiteit van visies. Uit de weergave blijkt dat gedachten over rendement telkens visies op de betekenis van de onderwijs- 
opbrengst voor de beroepspraktijk en het functioneren in het arbeidsleven impliceren. Vanuit deze gedachtengang is besloten - met inachtneming van de resultaten van eerder onderzoek (vgl. Frederix, 1978) en gelet op het feit dat beroepsvoorbereiding en -kwalificatie een centrale functie van het HBO is de toekomstig gewenste kwaliteit van onderwijs-opbrengst een van de kernthema's van dit onderzoek te maken.

\subsection{VISIES OP KWALTTETT}

\subsubsection{Kwaliteit als thema}

De kwaliteit van het onderwijs is een thema dat op velerlei wijzen kan worden opgevat. Kwaliteit kan bijvoorbeeld worden gezien als de inpasbaarheid en de inzetbaarheid in het arbeidsleven van abituriënten.

Bij de talrijke discussies hierover is ook het denken over de autonomie van het onderwijs ten opzichte van de eisen van de markt in het geding. In veel van de kritiek die aan het adres van het onderwijs wordt geuit, worden aan het onderwijssysteem eisen gesteld. Vaak wordt er (impliciet) van uitgegaan dat het onderwijs in zijn toeleveringsfunctie direct inzetbare mensen moet opleveren en dicht moet aansluiten bij de concrete eisen die op het niveau van functies worden gesteld.

Essentieel in dit onderzoek is hoe respondenten oordelen over de kwaliteit van het onderwijseindprodukt in de toekomst én de gewenste aansluiting van die eindprodukten bij behoeften in de beroepspraktijk. De onderwijsopbrengst wordt daarbij beschreven in termen van prestatiebeoordeling die in de beroepspraktijk gehanteerd wordt.

Welke elementen voor onderzoek naar het kwaliteitsaspect van betekenis te achten waren, werd vastgesteld aan de hand van literatuuronderzoek en discussies met experts in de sfeer van beroepspraktijk, onderwijspraktijk en intermediaire organisaties zoals b.v. in het Contactcentrum Onderwijs Arbeid. Daarbij is een aantal hoofdpunten van functioneren in de beroepspraktijk gedefinieerd. De mate waarin wenselijk wordt geacht dat het HBO bij de beroepsvoorbereiding aandacht schenkt aan de afzonderlijke aspecten werd in het survey nader onderzocht. Dit levert een algemeen overzicht van gezichtspunten op én een inzicht in de vraag in welke mate abituriënten uit het HBO in de toekomst, geacht moeten worden aan die eisen te voldoen. Toegespitst op dit domein van deze studie luidt de centrale vraag met betrekking 
tot de dimensie "kwaliteit": Welke elementen bepalen de kwaliteit van een toekomstige HBO-abituriënt, in de ogen van mensen in de arbeids- en opleidingspraktijk en de intermediaire organisaties? Het gaat daarbij om een set van cognities, houdingen en vaardigheden, plus de opinies van respondenten ten aanzien van de breedheid van professionele werkers in de toekomst én de vraag in welke mate het HBO adequaat moet voorbereiden op de eisen, die in de beroepspraktijk aan bod kunnen komen.

\subsubsection{Visies op kwaliteit en kwalificatie}

Tal van kwalificaties vormen de basis voor beroepsvoorbereiding zoals die binnen het $\mathrm{HBO}$ - voor uiteenlopende werkvelden - concreet wordt aangeboden. Het $\mathrm{HBO}$ treedt op tal van deelgebieden kwalificerend op en bereidt aldus voor op de beroepspraktijk. Wij herhalen de eerder geciteerde definitie van kwalificatie: ".. het geheel van kennis, vaardigheden en houdingen dat arbeidskrachten in staat stelt uiteenlopende arbeidsprestaties te leveren". (Van Hoof en Dronkers, 1980; p. 31). Essentieel hierbij is dat kwalificaties een belangrijk deel van iemands arbeidsvermogen vormen. Dit vermogen wordt opgebouwd door middel van formele en informele leerprocessen, zowel in het onderwijs als in arbeidsorganisaties. Deze definitie richt de aandacht niet alleen op het onderwijs, ook de beroepspraktijk heeft een kwalificerende werking. Daarnaast wordt ook de kwalificerende werking van andere omgevingen niet uitgesloten.

\subsubsection{Het begrip kwalificatie}

Aan het kwalificatiebegrip worden verschillende elementen en aspecten onderscheiden. In de definitie van Van Hoof en Dronkers werden reeds kennis, vaardigheden en houdingen als elementen genoemd. In dezelfde lijn wordt ook wel gesproken van cognitieve, technisch-instrumentele en sociaal-normatieve kwalificaties of kwalificatie-elementen.

Vanuit het gezichtspunt van de benutting van kwalificaties in de werksituatie, worden in de regel drie aspecten onderscheiden, te weten: een vaardigheidsaspect, een toepassingsaspect en een beheersaspect van de kwalificatie.

Uit de omschrijving van deze begrippen blijkt dat het niet gaat om scheidbare onderdelen van de kwalificatie, maar om aspecten van eenzelfde kwalificatie: het vaardigheidsaspect heeft betrekking op de cognitieve en psychomo- 
torische kanten van de te verrichten handeling, het toepassingsaspect op de inpassing van die handeling in de organisatie van het arbeidsproces en het beheersaspect op de samenhang van de handeling met andere handelingen in de desbetreffende werksituatie.

Naast de kwallificatie in deze brede zin, zijn bij de aansluiting van vraag en aanbod ook kenmerken in het geding die welliswaar niet of in mindere mate door het individu kunnen worden beinvloed maar wel behoren tot het geheel dat de werkzoekende op de arbeidsmarkt aanbiedt of waarom door werkorganisaties wordt gevraagd. Dit kunnen pure persoonskenmerken zijn (leeftijd) of kenmerken die door culturele invloeden worden bepaald, zoals de betekenis van en identificatie met arbeid.

In de opvatting van de SER-werkgroep (vgl. SER-nota 1981) moet het geheel van kenmerken dat de ontmoeting van vraag en aanbod op de arbeidsmarkt bepaalt, in de beschouwing van discrepanties en aanpassingsmogelijkheden worden betrokken. Dat daarmee ook toegeschreven persoonskenmerken worden ingesloten leidt ertoe dat slechts een deel van de kenmerken van het aanbod als verworven, of te verwerven, kan worden beschouwd. De niet-verworven persoonskenmerken kunnen op het niveau van de individuele aanbieder niet worden aangepast. Dit vormt echter geen afdoende reden om ze buiten de analyse te laten; immers een bepaalde constellatie van niet-verworven kenmerken van het aanbod kan well leiden tot aanpassingen in de omschrijving van de vraag op de arbeidsmarkt of in de benutting binnen het arbeidsbestel.

\subsubsection{Ontwikkelingen in de kwalificatie en de interactie van onderwijs-en beroepspraktijk}

Het onderzoek naar de ontwikkeling in benutte en gevraagde kwalificaties van arbeidskrachten heeft nog geen grote omvang bereikt. Met name in de Duitse literatuur is een aantal case-studies bekend die weliswaar uitsluitsel geven over de ontwikkeling van functie-niveaus en functie-inhouden in éen onderneming, maar waarvan de resultaten niet zonder meer gegeneraliseerd kunnen worden naar de gehele bedrijfstak. Ondernemingen blijken qua marktstrategie, organisatieregime en invoering van technische innovaties zodanig te verschillen dat op termijn ook de gewenste kwalificatiepatronen van de arbeid belangrijk kunnen verschillen. Dergelijke verschillen worden groter wanneer soortgelijke ondernemingen in verschillende landen worden vergeleken: verschillen in "managementcultuur", aangeboden de in de opleidingen verworven kwalificaties en arbeidsverhoudingen geven dan aanleiding tot geheel uiteenlopende patronen van gevraagde (en benutte) kwalificatie (vgl. Van Hoof/ 
Dronkers,1980, Beck e.a. 1976). In het algemeen hebben de case-studies geleid tot de conclusie dat de ontwikkeling van gevraagde kwalificaties naast de arbeidstechniek ook van de arbeidsorganisatie afhankelijk is (vgl. Kühlewind en Tessaring, 1975). De grenzen die de produktietechniek stelt zijn niet zo knellend dat daaruit eenduidig een behoefte aan arbeidskracht met een bepaalde kwalificatie voortvloeit.

Daarbij wordt als conclusie geformuleerd dat "generaliserende uitspraken over overscholing of onderbenutting geen aanknopingspunten bieden voor gerichte innovatiestrategieën in onderwijs- en arbeidssysteem" (vgl. SER-nota 1981, p. 46).

\subsubsection{Toekomstige ontwikkelingen}

Het onderzoek naar algemene trends in gevraagde (en aangeboden) kwalificaties kan in de komende jaren aanzienlijk worden verbeterd. Daarmee is echter niet gezegd dat de toekomstige ontwikkeling zich nauwkeuriger zal laten voorspellen. Dit zal mede afhangen van de mate waarin de geanalyseerde processen kunnen worden beschouwd als homogeen en wetmatig. In zoverre zij afhankelijk blijken van factoren waarvan de inhoud betrekkelijk snel verandert kan er niet op worden gerekend dat de toekomstige ontwikkeling een continue voortzetting van het verleden zal blijken te zijn.

Met de ontwikkeling van zowel gevraagde als aangeboden kwalificaties lijkt iets dergelijks aan de hand te zijn. Wat betreft de gevraagde kwalificaties is er wel op gewezen dat prognoses een geldigheid van niet langer dan twee jaar hebben (Van Hoof/Dronkers,1980, p.93). Dit hangt samen met de snelheid van de technische innovatie, (die de verkorting van de levenscyclus van produktieprocessen en produkten bepaalt) en met de wijze waarop veranderingen in de techniek organisatorisch worden vertaald. Als gevolg van dergelijke verbanden is de ontwikkeling van gevraagde kwalificaties op een algemeen niveau ongewis. Daarbij komt dat ondernemingen en andere organisaties geneigd zijn op hiaten in het aanbod van kwalificaties te reageren met aanpassingen in de vraag naar en de benutting van kwalificaties. Ook Teichler (1980) wijst op het feit dat de bepalingen van kwalificatievereisten vaak meer tentatief van karakter zijn dan algemeen wordt aangenomen (zie in dit verband ook Schleucher en Maskow (1983) en Eheim, Grünewall en Meifort (1982).

Zo er dus al in algemene zin een voorspelling zou kunnen worden gedaan over de uit technische veranderingen voortvloeiende vraag naar kwalificaties, dan nog zou daarmee geen inzicht ontstaan in de vraag die zich reëel op de arbeidsmarkt zal manifesteren. Dit alles maakt prognostisering een hachelijke zaak (SER-nota, 1981, p. 46 e.v.). 
Ten aanzien van de aangeboden kwalificaties geldt een aanzienlijk grotere voorspelbaarheid, althans wat de globale bezetting van verschillende niveaus betreft. De instroom van de verschillende onderwijssoorten verandert in het algemeen slechts geleidelijk; de inhoud van het onderwijs, en daarmee de opleidingskwalificatie van de abituriënten, eveneens. Hoewel de onveranderbaarheid wan het onderwijssysteem niet moet worden overdreven, kan men zeggen dat er in dit systeem institutionele traagheden werken tegen snelle en grootscheepse veranderingen van onderwijsinhoud en opleidingscapaciteit. De traagheden zijn uiteraard minder zwaarwegend naarmate er een duidelijker verband bestaat tussen de opleidingsinhoud en de uitoefening van een bepaald beroep, èn dit verband ook institutioneel is gelegd door een grotere betrokkenheid van de beroepspraktijk bij de ontwikkeling van opleidingen (vgl. Weisshuhn, 1977; Knip, 1981; Gorzka, 1985).

De geleidelijkheid wan veranderingen in het onderwijssysteem vergeleken met veranderingen in de beroepspraktijk, betekent echter niet zonder meer dat de aangeboden kwalificatie op de arbeidsmarkt slechts aan zeer geleidelijke verandering onderhevig is. De opleidingskwalificatie, die wordt verworven door het in enigerlei vorm volgen van onderwijs of scholing, is een deel van de kwalificaties en kenmerken welke de arbeidskracht aanbiedt. Zoals eerder gezegd behoren hier ook persoonskenmerken toe en kenmerken die veeleer door groepscultuur of millieu-achtergronden worden beïnloed dan door de formele opleiding.

Het effect van aanpassingsstrategieën die uitsluitend gericht zijn op de opleidingskwalificatie wordt daardoor enigszins gerelativeerd. Anderzijds is het denkbaar dat aanpassingen in de opleidingskwalificatie op hun beurt het belang van persoonskenmerken kunnen terugdringen. Deze overwegingen duiden erop dat veranderingen in opleidingen in het algemeen geleidelijk zullen verlopen en niet als enige factor de verandering van de aangeboden kwalificatie bepalen.

De ontwikkeling van gevraagde kwalificaties wordt al met al gekenmerkt door een geringe voorspelbaarheid. Hetgeen voorspeld kan worden is de toekomst van een veelheid aan beslissingsprocessen. De ongewisheid van de trend in gevraagde kwalificaties is mede het gevolg van de gecompliceerdheid en ondoorzichtigheid van deze beslissingsprocessen. Aanpassingsstrategieën gericht op de vraag naar kwalificaties zouden wellicht meer gebaat zijn bij een grotere doorzichtigheid van deze processen door informatie, en overleg, dan bij een nauwkeuriger voorspelling van de schijnbaar onvermijdelijke trend. Wanneer wordt gekozen voor een aanpassing van ontwikkelingen in de vraag ligt het voor de hand allereerst te kijken naar de flexibiliteitsmarges die aanwezig 
zijn en de wijze waarop deze door beslissingsprocessen binnen arbeidsorganisaties en binnen het onderwijs kunnen worden ingevuld.

Tem aanzien van het aanbod van kwalificaties is gewezen op de geleidelijkheid $\epsilon_{n}$ het door andere factoren afgezwakte effect van veranderingen in het onderwijs. Het ligt - aldus de eerder geciteerde SER-nota - meer voor de hand een grotere aanpassing na te streven door middel van gerichte ingrepen, dan op basis van wankele prognoses een langdurig en grootscheeps veranderingsproces in gang te zetten. Onderzoek naar bestaande flexibiliteitsmarges en de wijze waarop zij in het kader van beperkte en ingrijpende veranderingen kunnen worden benut (bijv. voor een snellere bijstelling van curricula of een grotere betrokkenheid van de beroepswereld), kan daaraan een grotere bijdrage leveren dan een analyse van globale trends in de kwalificatie-ontwikkeling. "Niettemin kan aan een fundamentele benadering niet voorbijgegaan worden: op onderdelen is verandering in onderwijsinhoud en opleidingscapaciteit ten zeerste gewenst." (SER-nota 1981, p. 49).

\subsubsection{Drie visies op het kwalificatiebegrip}

Door van Wieringen (1976, p.101 e.v.) zijn drie manieren aangegeven om het begrip kwalificatie te benaderen.

Met deze uiteenlopende opvattingen invulling van het kwalificatiebegrip komen ook drie verschillende visies op de verhouding van onderwijs en samenleving naar voren:

\section{- De technologische benadering}

Deze is technologisch genoemd omdat de verhouding tussen onderwijs en beroepswerkzaamheden gezien wordt als bepaald door technologische aspecten en niet door relaties tussen maatschappelijke groeperingen. In deze benadering bestaat een vrij enge relatie tussen de via een opleiding te leren beroepskwalificatie en de feitelijke beroepsuitoefening. Ze gaat uit van een gefixeerde relatie tussen opleiding en beroep.

\section{- De markteconomische benadering}

Deze gaat niet uit van een vastgelegd verband. Kwalificaties zijn op verschillende plaatsen op te doen en in verschillende werkzaamheden te gebruiken. In deze benadering wordt wel gewezen op de grote spreiding in de soort van beroepen door mensen met bepaalde soorten en niveaus van opleidingen. 


\section{- De integratieve benadering}

De in dit onderzoek gehanteerde benadering is de derde door van Wieringen geformuleerde. Deze koppelt het leren van kwalificaties aan de benutting van kwalificaties, maar de bestaande wijze van benutting wordt niet als gegeven aanvaard. In deze opvatting wordt juist als element gebruikt dat kwalificatie ook de geschiktheid impliceert, mede gestalte te geven aan de werksituatie waarin de kwalificatie gebruikt wordt. Deze benadering integreert zowel het opdoen van kwalificaties als het vermogen om met die kwalificaties de eigen werkpraktijk te beinvloeden. Voor het onderwijs betekent dit dat de werksituatie ook expliciet in het onderwijsprogramma opgenomen moet worden. Niet in de zin van een gerichtheid op een aantal nauw af te bakenen beroepen maar als een gerichtheid op de maatschappelijke werkelijkheid in een bredere betekenis van het woord.

\subsection{HET BEGRP KWALIFICATIE IN DEZE STUDIE}

Door ons wordt het kwalificatiebegrip aldus opgevat dat het alle kennis-, vaardigheids- en houdingsaspecten impliceert die mensen in staat stelt arbeidsprestaties te leveren. Dit vermogen wordt opgebouwd door formele en informele leerprocessen in onderwijsinstellingen en arbeidsorganisaties.

Het $H B O$ vervult daarbij een kwalificerende taak. Het bereidt voor op tal van eisen uit de samenleving en/of de beroepspraktijk en het staat met deze in voortdurende betrekking. De mate waarin het $\mathrm{HBO}$ adequaat op de eisen uit de praktijk voorbereidt is bepalend voor een oordeel over de "kwaliteit" van de abituriënten van het HBO. In deze zin wordt, in dit onderzoek, de relatie verstaan tussen het aspect "kwaliteit" en het begrip kwalificatie.

Tot zover een beknopte schets van het denken over kwalificatie, een resumé van mogelijke ontwikkelingen en een omschrijving van het kwalificatiebegrip in deze studie. Uit de bovenstaande weergave van visies op kwalificaties blijkt de relatie van onderwijs- en beroepspraktijk en de implicaties van de relatie van beide bij de benadering van het kwalificatiebegrip.

In hoofdstuk 4 (visies op de interactie van opleiding en beroepspraktijk) gaan wij op deze relatie nader in. Wij vervolgen deze paragraaf met een nadere uiteenzetting rond de begrippen kwaliteit en kwalificatie in dit onderzoek. 


\subsection{De gekozen tweedeling in kwalificaties}

In navolging van o.m. van Wieringen (1976) en van Kemenade (1981) wordt kwalificatie door ons onderscheiden in technisch-instrumentele en sociaal-normatieve kwalificaties. Technisch-instrumentele kwalificaties hebben betrekking op de kwalificaties van de beroepsbeoefenaar die in een directe en functionele relatie staan met de te leveren arbeidsprestatie. Sociaal-normatieve kwalificaties verwijzen naar de context waarbinnen de arbeidsprestaties moet worden geleverd en die daar direct of indirect functioneel voor zijn (bijvoorbeeld ideologische bestanddelen van de beroepsrol, loyaliteit e.d.).

Hoewel Van Hoof en Dronkers (1980) het door van Wieringen gemaakte onderscheid onderschrijven, maken zij ten aanzien van technisch-instrumentele kwalificaties nog een onderscheid tussen ".. voor een bepaalde functie specifieke benodigde kennis en vaardigheden.." en de "...meer algemene, minder direct aan een concrete functie gebonden eigenschappen..." (o.c.: p. 58). Zij hanteren daarvoor de termen "cognitieve uitrusting" en "trainability". Deze termen hebben vooral betrekking op de waarde die aan een onderwijsdiploma wordt toegekend. Het onderwijsdiploma wordt daarbij gezien als een "screening device". Het begrip trainability verwijst naar de kwalificerende rol die de beroepspraktijk heeft in de verdere ontplooiing van de HBO-er, terwijl cognitieve uitrusting verwijst naar de minimaal vereiste technisch-instrumentele kennis alvorens men toegelaten wordt tot de arbeidsplaats. Het gaat om de vragen die een selecteur of beoordelaar zich stelt: "Wat biedt de kandidaat aan en wat kan ik hem/haar leren?". Afhankelijk van de maatschappelijke context - met name de economische conjunctuur - zijn deze eisen aan verandering onderhevig (cf. Albeda, 1978).

Het gaat ons om de vraag of deze begrippen inderdaad een rol spelen bij de beoordeling van de kwaliteit van de $\mathrm{HBO}$-output. De onderzoeksvraag luidt welke visies mensen hebben op de output van het $\mathrm{HBO}$, een vraag die functiegebonden specificaties met betrekking tot cognitieve uitrusting overstijgt.

Rest het probleem van de begripsafbakening tussen sociaal-normatieve en technisch-instrumentele kwalificaties en traimability. Beide begrippen geven op zichzelf niet aan wanneer een kwalificatie moet worden beschouwd als verwijzend naar de context van de te leveren arbeidsprestatie (sociaal-normatief) of als een algemene, minder direct aan een concrete functie gebonden kwalificatie (technisch-instrumenteel). Wij begeven ons niet op het pad van de theoretische deductie, maar hanteren de begrippen sociaal-normatieve en technisch-instrumentele kwalificaties als globale classificatie-criteria voor de 
veelheid van aspecten van kwaliteit van $\mathrm{HBO}$-output die men in de praktijk hanteert. Wij gaan uit van eisen uit de praktijk.

Studies van Albrecht (1979), Mertens (1974), Mertens (1981), Boon (1979) en Schleucher en Maskow (1983) boden aanknopingspunten bij het ontwerp van een conceptueel schema met betrekking tot de kwaliteit van de HBO-output in de toekomst in deze zin. Het guote belang dat telkens aan sociaal-normatieve vaardigheden bleek te worden toegekend was aanleiding de onderzoeksvraag in deze studie daarop toe te snijden. Recent materiaal uit Limburg werd verder gevonden in twee ETIL-publikaties (ETIL 1985; 1986) over kwalitatieve knelpunten bij schoolverlaters resp. knelpunten tussen onderwijs en arbeidsmarkt ten aanzien van enkele speerpuntsectoren.

\subsubsection{Specifieke elementen van het kwaliteitsbegrip}

In het kader van deze studie wordt aldus à priori een onderscheid gemaakt tussen de technisch-instrumentele kwalificaties, (de toerusting die in een directe en functionele relatie staat met de in een functie te leveren arbeidsprestatie) en de sociaal-normatieve kwalificaties (de eigenschappen nodig om te kunnen functioneren in de sociale en organisatorische context waarbinnen de arbeid wordt verricht). Het onderscheid tussen technisch-instrumentele en sociaal-normatieve aspecten was in de aangeboden vragenlijst als zodanig niet herkenbaar. Wél is nagegaan welk belang werd toegekend aan de onderscheiden categorieën van kwalificatie-aspecten indien de scores worden geanalyseerd. In hoofdstuk 7 e.v. komen wij hierop terug.

De twee genoemde hoofdaspecten voor een indicatie van de toekomstige kwaliteit van een $\mathrm{HBO}$-abituriënt werden met enkele andere uitgebreid. Deze hadden een meer algemene strekking en werden evenmin geformuleerd op het niveau van een bepaald, concreet beroep.

De aldus verzamelde aspecten van onderzoek leverden een beeld van eisen dat het functioneren van HBO-abituriënten in voor hen adequate functies dekt, zij het op een hoog niveau van abstractie. Gepeild werd welke opbrengstkenmerken in ogen van de opleidings- en praktijkmensen in de toekomst wenselijk werden geacht. De eisen van de praktijk werden teruggebracht tot een aantal gezichtspunten op grond van de in het personeelswerk algemeen geldende beoordelingsaspecten. Deze zijn verder uitgewerkt in gesprekken met personeelschefs en getoetst aan een inventarisatie van aspecten die regelmatig centraal staan bij de discussie over de relatie over opleidings- en beroepspraktijk, onder andere binnen de Contactcentra Onderwijs-Arbeid. 


\subsubsection{Het aparte belang van sociaal-normatieve kwalificaties}

Het belang van voldoende oog voor sociaal-normatieve aspecten wordt in de literatuur frequent aangegeven. Ook door Huber wordt de importantie van sociaal-normatieve kwalificaties benadrukt. Hij accentueert het belang van dit complex van kwalificaties als volgt: "We moeten studenten helpen die strategieën en methoden te verwerven die geschikt zijn om de ontwikkelingen na te streven die we juist achten en die op het niveau van de politiek trachten door te voeren.

Dat vereist dezelfde vaardigheden als welke nodig zijn voor participatie: vaardigheden om te communiceren en samen te werken, om het werk met anderen te plannen en te organiseren, geduld en empathie, tolerantie, loyaliteit aan zijn/haar groep of institutie" (Huber, 1984, p.148 e.v.).

Door Polak (1983) is een beeld geschetst van het oordeel door afgestudeerden van het Hoger Onderwijs over de relatie tussen de in het Hoger Onderwijs verworven kwalificatie én hun werken. Hij geeft aan dat een klein deel van de respondenten ontevreden was over de aansluiting en "dat het onderzoek... doet vermoeden dat zaken als praktijkgericht werken, multidisciplinaire samenwerkingen, werken in ..verbanden, uitdrukkingsvaardigheid en omgang met mensen" in de bestaande opleidingen wel eens minder goed aan bod komen (Polak 1983, p. 62 e.v.). Ook de resultaten van de zogenaamde Netelcomstudie van latere datum (vgl. Boerwinkel, 1987) wijzen in deze richting.

\section{- klassificatie van aspecten}

De beide centrale begrippen zijn als klassificatie-criterium gehanteerd voor de veelheid van aspecten van kwaliteit van HBO-output die in de praktijk gelden. Uit de literatuur rond dit thema komen elf begrippen naar voren die als kwaliteitscriteria voor de $\mathrm{HBO}$-output worden gehanteerd (cf. o.a. Nijssen en Brons, 1978; Boon, 1979; Vlaskamp en Hövels, 1980; Van Hoof en Dronkers, 1980; Schleucher en Maskow 1983; Valkenburg en Hulskes, 1983; Bair en Mancuso, 1985; Wentink en Zanders, 1985; Cerych en Jallade, 1986). Deze begrippen zijn door ons als volgt geklassificeerd:

\section{Sociaal-normatieve kwaliteitscriteria:}

1. Zelfstandigheid

2. Contactuele eigenschappen

3. Eenzijdige versus meerzijdige inzetbaarheid

4. Dociliteit versus dominantie

5. Omgaan met veranderingen in de beroepspraktijk

6. Actieve deelname in beleidsontwikkeling 


\section{Technisch-instrumentele kwaliteitscriteria:}

7. Kennis en waardigheden

8. Uitdrukkingsvaardigheden

9. Klant- en actiegerichte instelling

10. Registratie en onderzoek

11. Marketing, fondswerving, budgetbewaking

\subsubsection{Uitwerking van de aspecten}

Onderstaand volgt een uitwerking van de 11 kwaliteitscriteria (tabel 1 en 2) alsmede een nadere detaillering van de overige aspecten met betrekking tot kwaliteit (tabel 3).

Tabel 1: Uhtwerking van de Sociaal-normatieve kwalikeiscriteria

$\begin{array}{ll}\text { Gezichtspunt: } & \text { Essentie: }\end{array}$

\section{Zelfstandigheid}

2. Contacuele eigenschappen

3. Eenzijdige versws meerzijdige inzewbararheid

4. Docilitent versus dominawie
De vrijheid, de ruimte die in de functie wordt gelaten
- gegevens en situaties be grijpen doorzien, ideeën ontwikkelen en initiatieven nemen

- eigen werk organiseren

- werk van anderen organise. ren

Het sociaal gedrag in en - omgaan ensamenwerken met buiten de beroepspraktijk collega's superieuren, vrijwilligers

- omgaan en samenwerken met medewerkers, leidinggeven

- optrieden naar buiten

- samenwerken met andere organisaties

- effectief deelnemen aan overlegsiltuaties

- eenzijdigheid/meerzijdigheid meerzijdig inzetbaar moet zijn

De mate waarin een abituriēnt past binnen organisaties en verhoudingen (dociliteit/dominantie) en de mate waarin een abituriënt, gevornd binnen eem. school (qua houding, conformiteit, etc.) past binnen de werkorganisatie. 
Venolg vabel 1: Uitwerking van de Sociaal-nomatiewe kwaliteiscriteria

\begin{tabular}{|c|c|c|}
\hline Gezichtspunt: & Essentie: & $\begin{array}{l}\text { Elenventen in de operathona- } \\
\text { lisatio: }\end{array}$ \\
\hline $\begin{array}{l}\text { 5. Omgaan met veranderingen } \\
\text { in de beroepspraktijk en } \\
\text { toekomstgerichtheid }\end{array}$ & $\begin{array}{l}\text { De snelheid waamee de leden } \\
\text { vaneensamenllevingendegenen } \\
\text { die haar besturen met verande- } \\
\text { thingen moeten omgaan neemt } \\
\text { toe. Het tijdig onderkennen } \\
\text { van mega-trends, van hoofdij- } \\
\text { nen van sociaal-politieke en } \\
\text { sociaal-economische ontwikke- } \\
\text { ling. Het bezig zijn net de } \\
\text { toekomst het omgaan met toe- } \\
\text { komstscenario's en -trends. }\end{array}$ & $\begin{array}{l}\text { - organisatieverandering } \\
\text {-ontwikkeling } \\
\text { - het ongaan met veranderi" } \\
\text { gen in de samenleving } \\
\text { - het begeleiden wan indivi- } \\
\text { duen bij verandering }\end{array}$ \\
\hline $\begin{array}{l}\text { 6. Actieve deelname in de } \\
\text { beleidsonmwikheling }\end{array}$ & $\begin{array}{l}\text { Het ontwikkelen van beleid, } \\
\text { het meedenken over de filo- } \\
\text { sofie van de ondememing of } \\
\text { instelling, het zoeken naar } \\
\text { nieuwe wegen, cliënten, tech- } \\
\text { nieken, diensten en produkten. } \\
\text { Het gaat hierbij om het } \\
\text { aanwenden van kennis en } \\
\text { vaardigheid om te komen tot } \\
\text { inschattingen van eisen die in } \\
\text { de toekomst zullen gelden. }\end{array}$ & $\begin{array}{l}\text { - beleidsontwikkeling wan be- } \\
\text { drijven en instellingen }\end{array}$ \\
\hline
\end{tabular}

Tabel 2. Uitwerking van de techmisch-instrumentele kwaliteitscriteria

$\begin{array}{ll}\text { Gezichtspunt: } \quad \text { Essentie: } & \begin{array}{l}\text { Elementen in operationa- } \\ \text { lisatie: }\end{array}\end{array}$

\begin{tabular}{|c|c|c|}
\hline 7. Kennis en vaardigheden & $\begin{array}{l}\text { Cognitieve. verworvenheden, } \\
\text { ervaringen, valudigheden, in- } \\
\text { zichten }\end{array}$ & $\begin{array}{l}\text { - theoretische kennis } \\
\text { - praktische kennis } \\
\text { - algentene kennis en ervaling } \\
\text { - specifieke beroepsgerichte } \\
\text { vakkennis en ervaring }\end{array}$ \\
\hline 8. Uitdrukkingsyaurdigheden & $\begin{array}{l}\text { Het onder woonden brengen } \\
\text { van gedachten in woord en }\end{array}$ & $\begin{array}{l}\text { - mondelinge en schriftelijke } \\
\text { udidrukkingsvaardigheid }\end{array}$ \\
\hline
\end{tabular}

9. Klan' en actiegerichte in- De mate waarin een abituriënt stelling

klantgericht werkt en een actiegeoriënteerde instelling heeft

10. Registratie en onderzoek

Registratie van gegevens en het verrichten of interpreteren wan verkennend, toetsend en effectbepalend onderzok

- klant- en actiegerïchtheid

- dataverzameling en dataanalyse

11. Marketing fondswerving Bijhet management van organibudgetbewaking saties en in de praktijk vam de uitvoe ringzijn fondswerving: budgetbewaking, marketing en techniek, belangrijke aspecten.

- marketing-technieken,fondswerving, budgetbewaking 


\section{Overige kwaliteitsaspecten}

Bij de onderzoekstechnische uitwerking van het begrip kwaliteit werden ook items opgenomen met betrekking tot indicatoren voor het denken over het kwaliteitsbegrip in de verhouding van beroeps- en opleidingspraktijk (vgl. van Wieringen op.cit. en van Kemenade, 1979). Dit is gedaan om de visies in kaart te brengen met betrekking tot de mate waarin zowel de beroepspraktijk als de onderwijspraktijk kwalificerend kunnen zijn. Ook aspecten van het zélf bepalen van de beroepspraktijk en visies op de breedte van het onderwijseen beroep dan wel een set van kwalificatieaspecten - kon hiermede worden bepaald. Het ging om de volgende gezichtspunten:

Tabel 3: Uitwerking van de owerige aspecten met betrekking tot kwaliteit

Gexichtspunt: Essentie: $\quad \begin{aligned} & \text { Elementen in de operatio- } \\ & \text { nalisatie }\end{aligned}$

12. De kwalificerende rol wan de onderwijspraktijk, resp. de beroepspraktijk

13. Bepalende invloed yan abi. twrièntent op de beroepsprakrijk

14. De breedke van het onderwijs qua beroepswoorbereiding
De beoordieling van de verhouding wan het opdoen van be roepskwalificaties in het onderwijs en in de beroepspraktijk. In aansluiting op de publikatie van wan Wierimgen (1976) is een aantal variabellen opgenomen met betrekking tot de beroepskwalifucerende rol van het onderwijs en de werhouding met de ervaring die in het beroep wordt opgedaan (het werkend opdoen van ervaringskennis)

In hoeverre moel het bepalen van de werkplek door de abituriènt als een doelstellingselement van het $\mathrm{HBO}$ gelden. Welke innovatieve kwaliteit is wenselijk? (vgd. Cerych en Jallade, 1986). Een ander aspect is of er binnen de beroepspraktijk concessies moeten worden gedaan aan de binnen het onderwijs verworven kwalificaties (wel verworven, maar niet direct of indirect bruikbaar c.q. nuttig als funktie-eis)

Moet het onderwijs gericht zijn op én beroep of op een set kwalificatie-aspectenverbonden aan een reeks van beroepen?
- de werhouding en vorm van beroeps-en opleidingspraktijk inzake het bieden van kwalificaties en kwalificatiemogelijkheden

- zelf vorm geven wherkplek

- beroepspraktijk concessiebereid ten opzichte van verworwenheid abituriënten

- brede scholing of specifieke voorbereiding op én beroep 
Deze output van het HBO is op tal van wijzen te beschrijven en te normeren. Ze kan worden getoetst aan "standards of performance" van het onderwijs zélf of aan eisen van de praktijk. Hoe ze naar de mening van experts in de toekomst zou kunnen zijn c.q. zou moeten zijn, wordt nader onderzocht.

$E_{r}$ is een aantal indicatoren geanalyseerd, relevant bij de beoordeling van de kwaliteit van de abituriënten in de beroepspraktijk. De beroepspraktijk, om dat het HBO daarop voorbereidt. Daarmee is de relatie tussen beide overigens niet lineair en eenduidig; ook elementen die betrekking hebben op het aspect lineariteit kregen in de onderzoeksopzet aandacht.

In totaal werden aldus elf directe kwaliteitsaspecten geformuleerd, waaraan het HBO aandacht zou kunnen schenken. Deze werden ontleend aan de personeelswerkpraktijk, aan ervaringen in het intermediaire circuit en aan relevante literatuur. Ze zijn te beschouwen als een globaal programma van mogelijke kwalificatie-eisen. Er is voorts een drietal indicatoren opgenomen die verwijzen naar de manier van denken over het begrip kwaliteit toegespitst op de rol van de beroepspraktijk en de onderwijspraktijk bij het ontwikkelen ervan. In totaal zijn veertien concepten geoperationaliseerd volgens onderstaand schema.

Tabel 4. Weergave van de elementen m.b.t. Kwaliteit

\begin{tabular}{ll}
\hline Domein & Kwaliteitsaspecten \\
\hline Subdomein & Saciaal-nornatieve criteria: \\
Elementen & 1. Zelfstandigheid \\
& 2. Contactuele eigenschappen \\
3. Eenzijdige versus meerzijdige inzetbaarheid \\
4. Dociliteit versus dominantie \\
5. Omgaan met veranderingen in de beroepspraktijk en toekomstgerichtheid \\
6. Actieve deelname in beleidsontwikkeling
\end{tabular}




\section{Interactie-aspecten}

\subsection{INLEIDING}

In dit hoofdstuk schetsen wij een aantal terreinen waarop de maatschappelijke rol van het onderwijs gestalte krijgt (par. 4.2) en komen tot een madere explicitering van gezichtspunten met betrekking tot de interactie van opleiding en beroepspraktijk (par. 4.3 e.v.) en de nadere operationalisatie van dit aspect.

\subsection{ONDERWIJS IN EEN BREDERE CONTEXT/DE MAATSCHAPPELUKE ROL VAN HET ONDERWIJS}

Wij stelden reeds vast dat bij het benaderen van het rendementsbegrip van het onderwijs steeds de functie van het onderwijs in het geding is. Wat geldt, sprekend over de relatie tussen beroepsonderwijs en de arbeidswereld als de functie van de school in relatie tot de eisen van de markt?

Ook ten opzichte van dit aspect doen uiteenlopende opvattingen opgeld. De school is onderdeel van de maatschappij en betrokken bij het ontwikkelingsproces en de groei naar volwassenheid van haar leerlingen. Het is evident dat de school méér is dan een instituut voor de opleiding voor een beroep. Zij richt zich er ook op, de leerlingen zo veelzijdig mogelijk persoonlijk te ontplooien en mondiger en weerbaarder te maken. Zowel voor de verdere ontwikkeling van wetenschap en techniek, als voor de ontplooiing van studenten wordt in de maatschappij veel van investeringen in het onderwijs verwacht. Kennisverwerving, -toepassing en -overdracht vormen een belangrijke stimulans voor de wetenschappelijke en economische vooruitgang. Adequate investeringen in "Human Capital" kunnen stimulansen geven om de technologische ontwikkelingen bij te houden c.q. daarop tijdig te anticiperen.

De eisen uit de samenleving aan het onderwijs zijn aan voortdurende verandering onderhevig; het onderwijs reageert op ontwikkelingen en geeft zelf actief vorm aan het ontstaan van nieuwe maatschappelijke en economische mogelijkheden. Zoals elke theorie ontstaat ook een onderwijstheorie niet in een maatschappelijk vacuüm. Zo is ook de bepaling van de functies van het 
onderwijs een thema, dat maatschappelijke aspecten heeft en ook daardoor voorwerp is van discussies en divergerende visies. Hierbij wordt wel een onderscheid gemaakt tussen de socialisatie-, de allocatie- en de kwalificatiefunctie van het onderwijs. (vgl. Frederix 1978, van Kemenade 1981, Vervoort 1975, Kohli 1973).

\section{Socialisatie}

De sociologische benaderingswijze vat onderwijs primair op als socialisatie. Door van Kemenade (1981, pag. 251) wordt dit begrip weergegeven als "het proces, waardoor de kennis en de beheersing van de verhoudingen, normen, waarden, vaardigheden en maatschappelijke technieken, nodig voor een adequate vervulling van de rollen, behorend bij de bepaalde posities in een sociaal systeem, worden overgedragen". Daarmee is de rol van het onderwijs echter nog niet afdoende gekenschetst.

Kenmerkend voor onderwijs is dat het gaat om georganiseerde en geprofessionaliseerde socialisatie:

- die zich binnen speciaal daarvoor gecreëerde sociale kaders afspeelt;

- waarbij mensen zijn ingeschakeld die professioneel aan de socialisatie van anderen werken.

De functie van het onderwijs wordt gezien als het geformaliseerde inlijvingsproces waarvan de samenleving zich bedient om leden van die samenleving voor te bereiden op de voornaamste rollen die moeten worden vervuld. Onderwijs vervult daarmee een stabilisatiefunctie. Het is het instrument waarover een samenleving beschikt om culturele continuiteit te garanderen. Volgens Vervoort (1975) komt het antwoord op de vraag, wat onderwijs in de samenleving uitricht, ten dele neer op de vraag naar aard, inhoud en betekenis van socialisatie als één van de voornaamste maatschappelijke functies van het onderwijs.

\section{Allocatie}

Onderwijs kent naast socialisatie "positietoewijzing" als tweede aspect. Wat vanuit het individu gezien socialisatie is, is vanuit de maatschappij gezien allocatie. Or 'erwijs socialiseert niet zonder meer, het socialiseert voor sociale posities. Die allocatieve functie is niet iets wat automatisch aan onderwijs vast zit. Zo kan men zich samenlevingen voorstellen, waarin de "positie-toewijzende" rol van het onderwijs tot een minimum is beperkt en waarbij in de socialisatie niet expliciet wordt vooruitgelopen op de toekomstige sociale 
posities, al zullen dan wel voorzieningen moeten worden getroffen om te kunnen voldoen aan eventuele specifieke eisen die de posities stellen. Verder kunnen er verschillen zijn in de wijze, waarop onderwijs een rol speelt bij allocatieprocessen.

Onderwijs kan rechtstreeks voldoen aan de kwalificatie-eisen die de positiestructuur stelt bijwoorbeeld door die kwalificatie-eisen te vertalen in opleidingsprogramma's en de beslissing over het al of niet bereikt hebben van een bepaald kwalificatieniveau aan zich te houden. Het kan ook een veel lossere relatie met de kwalificatiestructuur onderhouden en de controle op het bereikte kwalificatieniveau "buiten de deur houden, dat wil zeggen overlaten aan groeperingen die bij de handhaving van dit niveau belang hebben". (Vervoort 1975 , pag. 78). Volgens Vervoort zal in maatschappijvormen met een voortgeschreden arbeidsverdeling en met een gedifferentieerde kwalificatiestructuur het onderwijs. in sterkere mate toegesneden zijn op allocatie dan in minder gedifferentieerde maatschappijvormen, al kunnen er ook dan nog grote verschillen zijn in de wijze waarop socialisatie en allocatie met elkaar in verband worden gebracht. Voor de Nederlandse samenleving geldt, dat het onderwijs een - wellicht niet bewust uitgeoefende - doch feitelijk aanwezige en belangrijke functie toebedeeld kreeg, die van de "objectief" selecterende en daardoor positiebepalende instantie. Het onderwijs heeft in onze samenleving een grote sleutelmacht. Het is een belangrijk allocatiemechanisme en deze functie is grotendeels geïnstitutionaliseerd. De arbeidssectoren en het onderwijs zelf, eisen voor tal van posities scherp omschreven diploma's.

Dat het onderwijs tot een belangrijk allocatiemechanisme is geworden, heeft consequenties voor de aard en de inhoud van de socialisatie: een nauwe relatie tussen onderwijs en kwalificatiestructuur impliceert een terugkoppeling van de kwalificatie-eisen naar het onderwijs en daarmee een consequente oriëntatie van het onderwijs op die kwalificatie-eisen.

Het functioneren van het onderwijs als allocatiemechanisme is geen recent verschijnsel. Wel hebben zich in de allocatiecriteria verschuivingen voorgedaan, die neerkomen op een verandering van de positietoewijzing in de samenleving op grond van particularistische criteria (stand en afkomst) in de richting van een positietoewijzing op grond van universalistische criteria (geschiktheid). Onderwijs vormt niet meer, zoals in de vorige eeuw, de bevestiging van een bepaald statusniveau, maar differentieert naar een bepaald statusniveau toe op basis van prestatie. Het onderwijs wordt verder geacht deze differentiatie, die de grondslag vormt voor het allocatieproces, "objectief" naar universalistische criteria, tot stand te brengen. 


\section{Kwalificatie en interactie}

Een van de functies van het onderwijs is het aanbieden van kwalificaties (zie ook hoofdstuk 3, par. 3.3 in dit verband). De vraag is op welk type kwalificatie het onderwijs zich moet richten. Ook de kwestie of de noodzaak van de opvoering van de kwalificatiestructuur nu woor alle arbeidskrachten moet gelden, dan wel voor slechts een deel daarvan is actueel. In dit opzicht zijn enige opvattingen in omloop (vgl. Vervoort 1975, Beck e.a. 1976).

- Door de toenemende automatisering van de arbeid, vindt een reductie plaats van fysieke overbelasting en routine-arbeid. De verwachting is dat van alle arbeidskrachten in toenemende mate intellectuele vaardigheden zullen worden verwacht. Als indicatie voor deze tendens wordt gewezen op het groeiende aandeel van de functies waarvoor beroepsgerichte scholing noodzakelijk is.

- Als gevolg van de veranderende kwalificatie-eisen vindt een polarisering plaats onder de in loondienst werkzamen. Aan de ene kant staat een kleine groep van hooggekwalificeerde arbeidskrachten, die zowel in de industriële produktie als in de kantoorarbeid de lakens uitdeelt en de problemen formuleert waarvoor een oplossing moet worden gevonden. Aan de andere kant is er de grote massa van arbeiders en employees, die voornamelijk tot taak hebben de problemen op een bepaalde wijze routinematig op te lossen zonder dat daaraan hoge kwalificatie-eisen te pas komen.

- Het onderwijsstelsel moet zich in de toekomst op drie kwalificatietypen oriënteren:

- een betrekkelijk kleine topgroep van organisatorische en technische experts met grote beslissingsbevoegdheid ("professionals");

- een toenemende groep van flexibel gespecialiseerd technisch kader in uitvoerende posities ("technicians");

- een afnemende groep van arbeiders en dienstverlenend personeel met een technisch georiënteerde basisopleiding ("unskilled").

De afstemming van het onderwijs op de door de technologische ontwikkeling gedicteerde behoefte is niet eenvoudig, omdat de in de toekomst vereiste kwalificatiestructuur allerminst doorzichtig, laat staan gedetailleerd voorspelbaar geacht mag worden. Het postuleren van een relatie tussen industrialisatieprocessen enerzijds en de ontwikkelingen in onderwijssystemen anderzijds is, volgens Vervoort, niet zo moeilijk; veel problematischer is het hard maken van deze relatie, het concreet aangeven langs welke wegen en via welke mechanismen de afstemming precies plaatsvindt. Daarbij zal waarschijnlijk blijken dat er geen directe verbindingslijn loopt van het bedrijf naar de school (Vervoort 1975). 
Ook uit de boven geformuleerde visies op de maatschappelijke rol van het onderwijs blijkt de vervlechting wan het $\mathrm{HBO}$ met zijn maatschappelijke omgeving. De visies op de afhankelijkheid vormen opnieuw een van de eerdergeschetste spanningsbronnen tussen onderwijs en arbeid, zowel in structureel-technische als structureel-distributieve zin. Bedoeld zijn "de institutionele afschotting" tussen het reguliere onderwijssysteem en het reguliere arbeidssysteem als relatief zelfstandige maatschappelijke subsystemen. Afhankelijk van de ontwikkeling lijkt het onderwijssysteem, - per definitie - achter te lopen bij ontwikkelingen in het arbeidssysteem en ten opzichte daarvan in zekere afhankelijkheid aan de dag te leggen. In de volgende paragrafen gaan wij nader in op aspecten van deze afhankelijkheid en enkele visies die daarop bestaan.

\subsection{ASPECTEN VAN HET INTERACTIEBEGRIP}

\subsubsection{Onderwijs en arbeid als twee werelden}

Gelet op de discussies over en spanningsmomenten in de verhouding van onderwijs en arbeid is de stelling verdedigbaar dat onderwijs en arbeid van elkaar geïsoleerde werelden zijn geworden. Ons interesseert vooral hoe mensen oordelen over de in de toekomst wenselijk geachte verhouding van de beide werelden.

De visie op de interactie van een instelling voor beroepsonderwijs met de beroepspraktijk lijkt een van de factoren te zijn die in de beleving van mensen de kwaliteit van een school mede bepalen. Ook hier kan er sprake zijn van divergente visies. Is een $\mathrm{HBO}$-instelling een instituut dat openstaat naar en voor de beroepspraktijk, daarop actief georiënteerd is of daarvoor gesloten is en daar ver van afstaat? Een van de punten in de kritische beschouwingen door de omgeving van onderwijsinstellingen, is een verschijnsel dat wordt aangeduid met de term "het op zichzelf gericht" zijn van het onderwijs. De vraag is hoe ver de openheid van een school voor de omgeving moet gaan en welke punten van "performance" van een school deze (vooral) betrekking moet hebben en welke de rellevantie is van de omgeving voor een school.

Er lijkt op dit punt, overigens een zekere kentering op te treden. Zo signaleert van Wieringen (1983) een toenemende actieve omgevingsgerichtheid en vervlechting van scholen als instituut en occupatie met taken op het terrein van maatschappelijk dienstbetoon.

Dit lijkt een belangrijk aspect voor het denken over de toekomst op te leveren: onmiddellijk hiermee verbonden is ook de wederzijdse openheid van 
onderwijs en beroepspraktijk. Veel van wat aan kritiek wordt gehoord over "geslotenheid en op zichzelf gerichtheid van het onderwijs" is wellicht in gelijke mate geldig voor instellingen in de sector arbeid in hun gerichtheid op het onderwijs.

De pleidooien voor een meer open en effectieve dialoog tussen onderwijspraktijk en beroepspraktijk zijn talrijk. Deze en andere aspecten kenmerken de discussies over interactie tussen onderwijs en arbeid. Meer specifiek is de beoordeling van de in de toekomst wenselijk geachte verhouding tussen $\mathrm{HBO}$ en beroepspraktijk en het inspelen op de beroepspraktijk door het $\mathrm{HBO}$, daarbij aan de orde.

De beoordeling van de verhouding tussen opleiding en beroepspraktijk vindt steeds vanuit verschillende posities en gezichtspunten plaats. De beroepenwereld en de ontwikkeling daarin vormen voor (studie-afdelingen van) het HBO een belangrijke informatiebron én kunnen een belangrijk oriëntatiepunt zijn. Binnen de Sociale Academie heeft Knip (1981) vier studierichtingen met een veelvoud aan relevante beroepspraktijken onderzocht. Hij wijst erop dat de meest duidelijke situatie met betrekking tot de verhouding tussen beroepsen opleidingspaktijk daar bestaat "waar geprobeerd wordt een streven in stand te houden naar consensus over criteria voor een adequate beroepsuitoefening". (1981, p. 50 e.v.).

In een dergelijke beroepspraktijk neemt de onzekerheid voor de opleiding af naarmate de voortgang vordert naar volledige professie. Daardoor neemt de duidelijkheid toe over het daarbij behorende geheel van kennis en bekwaamheid. Complexer is het verband tussen beroepsontwikkeling en onzekerheid in beroepspraktijken waar sprake is van een bepaalde segmentering in de beroepsontwikkeling, waar professionalisering in termen van wording-tot-professie omstreden is. Een streven naar consensus over criteria voor beroepsuitoefening wordt dan erg onwaarschijnlijk, zeker zolang geen enkele groepering binnen de beroepspraktijk in staat is haar wil aan andere groepen op te leggen. Onderstaand gaan wij nader in op enkele aspecten die voor het begrip van interactie relevant zijn.

\subsubsection{De oriëntatie op de beroepspraktijk}

Er zijn experts die ervoor pleiten dat de afstand tussen opleidingsinstituten en hun omgeving niet groot genoeg kan zijn. De school heeft in hun optiek een zodanig eigen verantwoordelijkheid dat zij voorloper moet zijn voor de inrichting van de beroepspraktijk. Deze beroepspraktijk kan (ideaaltypisch) op twee manieren worden gezien: ten eerste als volledig geprofessionaliseerd 
met min of meer vastomlijnde kennis en methodieken en duidelijke kwaliteitscriteria en ten tweede als een gebied van professie-in-wording zonder vastomlijnde kennis en methodieken en zich voortdurend wijzigende kwaliteitscriteria.

Knip (1981) wijst in dit verband op de keuzemogelijkheden die de HBO-opleiding heeft: men kan de ontwikkelingen in de omgevingscondities afwachten en daar op passieve wijze op inhaken (de re-actieve opstelling) of men loopt op de ontwikkelingen in de omgeving vooruit (de pro-actieve opstelling).

De aard van de interactie tussen het HBO en de beroepspraktijk is te beschrijven aan de hand van de kenmerken van beide partijen: de beroepspraktijk naar de mate van professionalisatie en het HBO zelf naar de mate van proof re-actieve opstelling.

Mertens (1981) komt in zijn studie met betrekking tot het Hoger Technisch Onderwijs tot de conclusie dat in situaties waarin men opleidt voor een beroepenveld in plaats van een specifiek beroep, de interactie heel wat minder problematisch is dan in die situaties waarin men opleidt voor een specifiek beroep.

Ook voor de marktsector geldt dat deze voortdurend in ontwikkeling en beweging is (vanuit dat besef zijn de curricula voor het technisch onderwijs juist breed gedefinieerd). Men kan echter moeilijk stellen dat de technische beroepspraktijk nog volop in een professionaliseringsfase verkeert. De bevindingen van Mertens wijzen op een andere factor die in de aard van de interactie een rol speelt, nl. de heterogeniteit van de beroepspraktijk. Naarmate een beroepspraktijk heterogener van samenstelling is, kan men er niet omheen curriculum-eisen breder te definiëren, wil er althans nog van enige aansluiting sprake zijn.

We kunnen constateren dat er de laatste jaren (mede door de regelgeving van de overheid) een toename valt waar te nemen in het contact tussen opleidingen en beroepsveld. De vraag is hoe de institutionele scheiding tussen werkveld en opleiding moet worden gewaardeerd. Is het goed, zoals vanuit de opleidingen wel gebeurt, hier te spreken van een vruchtbaar spanningsveld of moeten schoolse beroepsvorming en vorming in de beroepspraktijk veel meer in ruimte en tijd samenhangende processen zijn? (vgl. Hegelheimer 1983, Malglaive en Weber 1983).

Al eerder is het punt van de zelfstandigheid van het onderwijs aan de orde geweest. Het lijkt er wel eens op dat van de zijde van de beroepspraktijk die autonomie in deze zin niet gering genoeg kan zijn. Gevers heeft erop gewezen, dat de autonomie van het onderwijs zowel de grondwettelijke vrijheid van onderwijs als de eigen inrichting van het onderwijs en ook het eigen 
meesterschap in zelfsturende zin omvat. Niet alleen als leerstelling en als claim van het onderwijs zelf echter dient autonomie te worden nagestreefd, maar ook vanwege meer bestuurlijke noties als verantwoordelijkheid en doelmatigheid. "Het is eenvoudigweg beter dat onderwijs autonoom is". (zie van Gageldonk e.a., 1983, p. 138). De auteur wijst op de in het Nederlandse onderwijsbeleid aanwezige traditie om zelfregulering te doen samengaan met volledige overheidsbekostiging, met van buitenaf te handhaven kwaliteitseisen en met centrale regelgeving en normstelling. Dat neemt echter niet weg, dat het naar zijn mening om twee tegengestelde, wellicht zelfs ten principalie onverenigbare benaderingswijzen gaat. Wie tegelijk het roer in handen wil hebben, maar voor het schip van anderen afhankelijk wil zijn, kan niet beide strevingen ten volle realiseren. Om toch staatszorg beschikbaar te maken en staatsonderwijs te vermijden moet er bij voortduring "iets" gedaan worden. Daarom is de autonomievraag de eerste inbreuk op het "op zijn beloop laten". Gebrek aan autonomie én flexibiliteit in het Hoger Onderwijs wordt ook als eerste knelpunt geformuleerd in de (eerder geciteerde) notitie "Hoger Onderwijs, Technologie en Marktsector".

Daar heet het dat instellingen van H.O. te weinig flexibel zijn om adequaat te kunnen inspelen op signalen uit de omgeving. Met name het $\mathrm{HBO}$ is bovendien sterk beperkt in de bewegingsvrijheid door directe bemoeienis van de rijksoverheid. Toename van autonomie van de instellingen en van flexibiliteit van het H.O.-systeem als geheel is voorwaarde voor een versterking van de relatie met de marktsector". (Kamerstuk 19454, p. 20). Deze notitie wijst verder op het gebrek aan signalen uit de marktsector; ontwikkelingen in de marktsector worden te weinig verwoord en vertaald naar mogelijke wensen van en gevolgen voor het H.O. In deze wordt (in de H.O.A.K.-nota, 1985) een actieve rol voor het Ministerie van Economische Zaken voorzien terwijl ontwikkelingen op de arbeidsmarkt - zowel kwantitatief als kwalitatief - dienen te worden geanalyseerd in een permanent overleg tussen de Ministeries van Onderwijs, Economische Zaken en Sociale Zaken en Werkgelegenheid.

Er zijn echter meer factoren die een rol spelen in de interactie. Wij noemen bijvoorbeeld opvattingen van bestuurlijke aard, zoals geformuleerd in de nota "Hoger Onderwijs, Technologie en Marktsector": "Instellingen van Hoger Onderwijs zijn te weinig flexibel om adequaat te kunnen inspelen op signalen uit de omgeving. De nota noemt naast gebrek aan autonomie en flexibiliteit ook het gebrek aan signalen uit de marktsector en de weinig gestructureerde samenwerking tussen het hoger onderwijs en de marktsector (te veel ad hoc) als knelpunten. 
Oplossingen worden gezocht in investeringen in apparatuur, technologische nascholingsprojecten en versterking van het technologisch-wetenschappelijk onderzoek. Ook het instellen van regelmatig overleg op ministerieel niveau over de relatie hoger onderwijs en beroepspraktijk wordt geadviseerd.

\subsubsection{De invloed van de markt op het ondenwijs}

De relatie van beroepsonderwijs en beroepspraktijk kan worden geplaatst tegen de achtergrond van de meer algemene relatie van onderwijs en (arbeids)markt. De invloed van het bedrijfsleven op het onderwijs is al geruime tijd onderwerp van discussie. Mede door de rapportage van de Commissie Wagner, de toenemende omgevingsgerichtheid wan het onderwijs, het functioneren van de C.O.A.'s en de tendensen in de landelijke regelgeving, staat het thema van de afstemming van onderwijs en arbeid de laatste tijd sterk in de belangstelling.

Volgens Mertens is deze afstemming vooral de verantwoordelijkheid van de afzonderlijke instellingen. "We moeten af van de idee dat dit centraal en deductief te bepalen is en dat het dan goed is. Het via landelijke organen voorschrijven van beroepsprofielen en eindtermen is niet de juiste weg" (1981, p. 78 e.v.). Mertens wijst erop dat deze wijze van werken de verantwoordelijkheid weghaalt bij de instellingen, ze versterkt de rigiditeit en is zeker geen garantie voor effectiviteit.

"Zeker moeten we af van de idee dat elk beroep zijn eigen opleiding moet hebben, tenzij we ophouden - vooral in de kwartaire sector - met het steeds weer uitvinden van nieuwe beroepen". Voor de ontwikkeling van de onderwijsprogramma's in het Hoger Onderwijs is het gewenst dat de instellingen zich hierbij bedienen van methodes als "marketing" en "strategische planning".

Dit soort toegepaste managementtechnieken geeft een grotere garantie voor een adequaat opleidingsbeleid in de instellingen voor Hoger Beroepsonderwijs dan te trachten door middel van "linking-pin" functionarissen in bijvoorbeeld schoolbesturen iets als aansluiting tussen vraag en aanbod te creëren.

"Deze mechanismen, die bijvoorbeeld ook door de Commissie Wagner voorgesteld zijn, mogen adequaat geweest zijn in voorbije perioden, maar op dit moment geven ze geen garantie voor een juiste beleidslijn in de opleidingsinstituten. In het Hoger Beroepsonderwijs is de curriculuminhoud nogal sterk door "meningen" van mensen bepaald. Er zijn Mertens nauwelijks pogingen bekend "om aan de programma's een meer rationele fundering te geven." (Mertens, 1981, p. 79 e.v.). Zo'n fundering is de kern van de eerdergenoemde managementtechnieken. Niet dat daarmee exact te bepalen is wat moet, maar 
de kans op fouten wordt erdoor verkleind. Langs een dergelijke weg kunnen ontwikkelingen in de technologie meer betrouwbaar bepaald en vertaald worden in programma-aanpassingen".

De afstemming en samenwerking in deze zin heeft ook een rol gespeeld in een specifiek tot Limburg beperkte studie. Polak (1981) formuleerde in bet kader van een studie ower modellen van samenwerking op het terrein van het Hoger Onderwijs in Limburg een aantal punten waarop het onderwijs meer in het algemeen tot een betere afstemming kan komen. Hij noemde daarbij als voorbeelden:

- het afstemmen van de onderwijscapaciteit van met name typische beroepsopleidingen op de kwantitatieve en kwalitatieve vraag van de arbeidsmarkt;

- het ontwikkelen van de opleidingsvarianten waarvan de afgestudeerden mogelijk een bijdrage kunnen leveren aan het oplossen van maatschappelijke problemen (gedacht kan worden aan bijv. varianten op het vlak van sociaal en industrieel management);

- een grote aandacht in het curriculum voor de aard van de activiteiten, waarmee de student na afloop van de studie in een werkkring of anderszins geconfronteerd kan worden (vgl. Mertens, 1981);

- voorlichting voorafgaand aan en tijdens de studie over de latere beroepen waarvoor wordt opgeleid.

Voorts wees Polak op mogelijkheden voor een verdere afstemming tussen de instellingstaken op het vlak van onderzoek en maatschappelijke dienstverlening en de samenleving, bijvoorbeeld door: het creëren van een regionaal gericht "servicestation" voor industriële innovatie (vgl. van Wieringen 1983) en de mogelijke voorwaarden om docenten tijdelijk adviesfuncties te laten vervullen in bedrijven, overheids- of particuliere instanties.

De antwoorden door het Hoger Beroepsonderwijs in de afgelopen jaren gegeven op behoeften uit de praktijk (nieuwe opleidingen, specialisaties, differentiaties etc. zijn indrukwekkend. Doch dit is slechts éen aspect van de relatie; een ander aspect is hoe de interactie met de beroepspraktijk moet worden ingevuld.

Het gaat er niet alleen om, vast te stellen welke antwoorden er in de sfeer van capaciteitsverbetering en differentiatie worden gegeven, maar ook om de vraag met welke oriëntatie op de markt het onderwijs functioneert. Dat is én aspect. Het andere is of en hoe actief de markt en daarbinnen de beroepspraktijk op het onderwijs georiënteerd is. Waar het gaat om de afstemming van het Hoger Onderwijs op de marktsector constateert de notitie "Hoger Onderwijs, Technologie en Marktsector" (kamerstuk, 1985, p. 15) dat een 
goede aansluiting van het onderwijs op de arbeidsmarkt voor zowel afgestudeerden als het bedrijfsleven essentieel is. Geconstateerd moet echter worden dat een bepaling van de reële behoefte aan afgestudeerden in het bedrijfslewen nauwelijks aanwezig is en ook moeilijk te verkrijgen is. Vaak dient zich een acute behoefte vanuit de marktsector aan die door het onderwijssysteem niet direct wervuld kan worden. Het is verder ook niet te verwachten dat knelpunten in de aansluiting onderwijs en arbeidsmarkt volledig zijn op te lossen. (vgl. SER-nota 1981). Wel kan gestreefd worden naar een vermindering van problemen in de aansluiting. Een voortdurende actieve dialoog tussen de onderwijspraktijk en de beroepspraktijk kan daarbij een essentieel middel zijn (vgl. van Iersel, 1986).

Al met al blijft de relatie tussen het $\mathrm{HBO}$ en de marktsector complex, waarbij de volgende factoren een rol spelen (Bickeboller-Kubiak 1982, Interaction 1982):

- technologische ontwikkelingen veriopen, na een aarzelende aanvangsfase, stormachtig naar een bepaald verzadigingsniveau. Een aantal technologieën (b.v. informatietechnologie) bevindt zich thans in de fase van ontwikkeling en snelle verandering. Tal van onzekerheden over de mate waarin deze ontwikkeling zich doorzet en over de manier waarop onderwijs en onderzoek daarop in zullen spelen, zijn daar het gevolg van;

- het Hoger Onderwijs staat wat betreft al zijn taken (onderwijs, onderzoek en kennisoverdracht) onder druk. De roep om een grotere markt- en klantgerichtheid van het H.O.-systeem vragen flexibiliteit en aanpassingsvermogen. Tegelijkertijd dient het zuiver-wetenschappelijk onderzoek en het toepassingsgerichte onderzoek op een kwalitatief hoog niveau gebracht te worden;

- binnen de marktsector bestaan veelal drempels van psychologische en culturele aard voor samenwerking met een instelling van H.O. Dit betreft een verschil in benadering tussen een kosten-batenanalyse en vrijheid van onderzoek en het spreken van een verschillende taal;

- de marktvraag is doorgaans slecht gearticuleerd, waar het gaat om wensen van de beroepspraktijk. Signalen uit de marktsector, zowel ten aanzien van ontwikkelingen in de arbeidsmarkt als ten aanzien van wetenschappelijke en technologische ontwikkelingen, zijn zwak of ontbreken;

- bovendien geldt een "time-lag" van 5 jaar om in het onderwijs veranderingen door te voeren, als vrij normaal. 


\subsubsection{Het verschil in culfureel klimaat}

Het verschil in "cultureel klimaat" tussen de school en de beroepspraktijk wordt well verklaard door het bestaan van verschillende verwachtingspatronen, onvoldoende communicatie en een gebrekkige afstemming van de opleidingsinhoud enerzijds en de eisen vanuit de functieuitoefening anderzijds (zie bijvoorbeeld Schouten e.a., 1975, p. 20 e.v.).

Ritzen (1983) gebruikt de term "culturele isolatie", waarmee geduid wordt op een verdergaande verwijdering van het onderwijs van zijn relevante omgeving en een terugvallen van het onderwijs op zichzelf. De traditioneel bepaalde gerichtheid van het onderwijs om zich van de buitenwereld af te sluiten en zich voornamelijk binnen de grenzen van de "pädagogische Provinz" te bewegen èn het feit dat er in het voortgezet onderwijs vaak te weinig aandacht wordt geschonken aan de maatschappelijke werkelijkheid, waarvan arbeid en beroepsleven een belangrijk deel uitmaken (vgl. van Kemenade 1979 en 1981, Interaction 1982, Bickeboller-Kubiak 1983) heeft in tal van beschouwingen een repeterend karakter.

De culturele isolatie van het onderwijs is wellicht terug te voeren op het feit dat van het onderwijzend personeel veel mensen geen beroepspraktijkervaring buiten de onderwijssector bezitten. "Veel van de mensen, die in het onderwijs werken, hebben het onderwijs in feite nooit verlaten. Na kleuter-, lagere en middelbare school hebben ze een opleiding tot onderwijsgevende gevolgd en vervolgens werk gevonden in het onderwijs. Sociale contacten spelen zich vooral af met collega's uit het onderwijsveld." (Ritzen, 1983 p. 86 e.v.). Op het punt van deze culturele isolatie van het onderwijs zijn, ook in het beleid van de rijksoverheid, veelbelovende aanzetten te ontdekken. Er wordt bijwoorbeeld actief naar gestreefd om via de zogenaamde C.O.A.'s (Contactcentra Onderwijs-Arbeidsmarkt) voor onderwijsgevenden stages in bedrijven te organiseren en ook daardoor een concrete brug te slaan tussen onderwijspraktijk en beroepspraktijk.

\subsubsection{De C.O.A.-bijdragen en omgevingsgericht onderwijs}

Op grond van de regelgeving en financiering door de centrale overheid zijn in 1983 proefprojecten opgezet, die ten doel hebben als Contactcentra voor Onderwijs en Arbeid (C.O.A.'s) te fungeren. In termen van de rijksregelgeving uit 1983 is de doelstelling van deze C.O.A.'s te definiëren als: het verbeteren van de relatie tussen onderwijs en arbeid door middel van: 
- het bevorderen van stages;

- het coördineren c.q. afstemmen van school-, studie- en beroepskeuzewerk;

- het verzamelen en loegankelijk maken van kennis omtrent (ontwikkelingen in) het onderwijs, het werk en hum onderlinge samenhang;

- overige activiteiten, die bijdragen tot het verbeteren van de relatie tussen onderwijs en arbeid.

Uit een systematische evaluatie van de in C.O.A.-werband verrichte activiteiten blijkt, dat de hoofdelementen van de doelstelling ruimschoots zijn gehaald (zie in dit verband ook te Wierik, 1986). Van Wieringen (1983, p. 118) heeft drie perioden onderscheiden in de ontwikkeling van de relatie tussen onderwijs en arbeid. Hij ziet in de tweede periode nieuwe infrastructurele voorzieningen (C.O.A.'s; commissies voor beroepenvelden etc.). Ten aanzien van de derde periode, die in aantocht is, concludeert hij tot een breuk met de tweede periode "als we kijken naar een van de meest opvallende veranderingen ten aanzien van infrastructurele voorzieningen die vanuit het wetenschappelijk onderwijs komen overgewaaid, die activiteiten die we aanduiden met termen als wetswinkels, onderwijswinkels, transferpunten, innovatiecentra enz.

In alle gevallen wordt de onderwijsinstelling gezien als meer dan een instelling die mensen opleidt. Er wordt een directe relatie gelegd tussen instelling en maatschappelijk/arbeidsbestel. Deze activiteiten komen voort uit pogingen om in de behoefte van achtergestelden wia bepaalde diensten te voorzien. Ook het opzetten van transferpunten komt uit een min of meer vergelijkbare wens voort. $\mathrm{Nu}$ is het tanend bedrijfsleven als behoeftig gedefinieerd en wordt geprobeerd het potentieel van de hogeschool en universiteiten na 15 jaren van kritiek en distantie weer in te zetten voor directe contacten, dienstverlening e.d. Transferpunten zien we nu nog vooral in het wetenschappelijk onderwijs. Ze bevorderen kennisoverdracht naar vooral kleine en middelgrote bedrijven.

De transferpunten zijn vooral op te vatten als makelaar, als bemiddelaar tussen bedrijfsprobleem en onderzoekers/ontwikkelingspotentieel" (van Wieringen, 1983, p. 119). Deze vorm van de relatie tussen onderwijs en arbeid acht van Wieringen als waarschijnlijk toonaangevend voor de derde periode. Het onderwijs staat opnieuw voor de vraag "aan te geven hoe ver ze wil gaan in vereenzelviging met de praktijk". De relatie tussen onderwijs en arbeid wordt hier dan veel meer gezien in niet-pedagogusche termen, namelik in termen van bijdrage aan het produktief vermogen. In de tweede periode werd nog een belangrijke plaats weggelegd voor stages, praktijkleerplaatsen, arbeidservaringsleren e.d. mits onderwijskundig goed ingevuld In de derde periode blijft deze lijn doorlopen, maar de schijnwerper zien we toch vooral gaan naar de niet conventionele aansluitingsvormen. 
Niet-conventioneel: uiteraard niet in de ogen van diegenen die de eerste periode hebben meegemaakt. Daarom is, aldus van Wieringen, de vraag gerechtvaardigd wat we doen in deze periode: zonder meer teruggaan naar een wederopbouw-periode of hebben we toch voldoende overgehouden aan culturele opbrengst uit de tweede periode om scherpzinnig en met behoud van pedagogisch optimisme de relatie opnieuw te doordenken? Om de indicaties naar de visies op de markt gewenste verhouding tussen onderwijs- en beroepspraktijk te completeren, is bij de technische uitwerking van dit aspect in het onderzoek ook ingegaan op de beoordeling van de betekenis van stages.

\subsection{SAMENVATTING}

De relatie HBO en beroepspraktijk is hier opgevat in termen van de oriêntatie van het $H B O$ op de beroepspraktijk en vice versa.

De opstelling die het HBO daarbij kiest, wordt onder meer bepaald door de mate waarin de beroepspraktijk is ontwikkeld en geprofessionaliseerd.

Andere factoren die de aard van de interactie lijken te bepalen, zijn de heterogeniteit en veranderlijkheid van de beroepspraktijk en de autonomie en de flexibiliteit van het onderwijs. Daarbij zijn ook verschillen in cultureel klimaat van het $\mathrm{HBO}$ en de beroepspraktijk een factor van betekenis in de aard van de interactie (van Gageldonk, 1983; van Kemenade, 1981; Ritzen, 1983).

De begrippen die aan de orde zijn geweest, zijn onderstaand samengevat.

Tabel 5: Weergave van de elementen m.b.t. Interactie

\begin{tabular}{ll}
\hline Domein & Interactie HBO-Beroepspraktijk \\
\hline Subdomein & Aspecten van de beroepspraktijk \\
Element & 1. De verandertijkheid van de be roepspraktijk \\
& 2. De opstelling t.o.v. het onderwijs \\
& 3. De visies op stages \\
Subdomein & Aspecten vart de ondenwijspraktijk \\
Element & 4. Pro-en re-actieve opstellingen \\
& 5. De autonomie van de opleiding \\
& 6. De beroepsgerichtheid van het onderwijs \\
Subdomein & Aspecten van concrete samenwerking \\
Element & 7. Verschillen in cultur tussen onderwijs en arbeid \\
& 8. Kaders en frequentie van overleg \\
\hline
\end{tabular}

De afzonderlijke elementen van het interactiebegrip zijn uitgewerkt in de vragenlijst. 


\section{Structuur- en organisatie-aspecten}

\subsection{INLEIDING}

Tot dusver zijn twee aspecten van de relatie $\mathrm{HBO}$ en beroepspraktijk aan de orde geweest; de kwaliteit wan de HBO-opbrengst en de aard van de interactie tussen het HBO en de beroepspraktijk. Ervan uitgaande dat gegeven structuren geen dwingend handelingskader vormen, maar de ruimte bieden veranderingen aan te brengen, moet men bij de bestudering van de relatie $\mathrm{HBO}$ en beroepspraktijk rekening houden met ontwikkelingen in de structuur en de organisatie van het $\mathrm{HBO}$.

Wij zullen daarop in dit hoofdstuk ingaan. Allereerst schetsen wij globaal de ontwikkeling van beleid met betrekking tot het nieuwe kader voor het HBO en enkele aspecten van de discussie op dit punt (par. 5.2). Daarna volgen (par. 5.3) enkele mega-trends die voor de toekomst van de maatschappij en voor het Hoger Beroepsonderwijs gelden.

\subsection{HET NIEUWE KADER VOOR HET HBO}

In het voorgaande is aandacht geschonken aan visies op de functies van het onderwijs dat in de samenleving een allocatiefunctie vervult. Deze functie, die met betrekking tot het HBO expliciet geldt, wordt verwoord in de Wet op het Voortgezet Onderwijs. De in deze Wet vervatte onderwijsdoelstellingen voor de verschillende soorten HBO spreken over "voorbereiding geven voor beroepen".

De nieuwe Wet op het Hoger Beroepsonderwijs geeft naar analogie van de Wet op het Wetenschappelijk Onderwijs ruimer baan an de socialisatiegedachte, zonder daarbij de voorbereiding tot beroep te doen vervagen. Centraal blijft de gedachte "voorbereiding voor een beroep", met dien verstande dat naast de theoretische en de praktische vorming ook aspecten als ontplooiing en maatschappelijk functioneren binnen de opleiding gestalte dienen te krijgen. Het $\mathrm{HBO}$ is uit de Wet op het Voortgezet Onderwijs gelicht. Het heeft een eigen wettelijke regeling die een plaats kreeg in een wettelijk 
kader voor het gehele Hoger Onderwijs. Volgens artikel 2 van de Wet Hoger Beroepsonderwijs is: "Hoger Beroepsonderwijs een vorm van Hoger Onderwijs en gericht op de theoretische en praktische voorbereiding tot het uitoefenen van beroepen waarvoor een hogere beroepsopleiding vereist is of dienstig kan zijn en bevordert in samenhang daarmee de persoonlijke ontplooing en het maatschappelijk functioneren. Het Hoger Beroepsonderwijs sluit aan bij het eindniveau van de hogere vormen van voortgezet onderwijs".

Artikel 3 spreekt over de taak van de instellingen die HBO verzorgen. $\mathrm{Zij}$ dragen bij aan de ontwikkeling van beroepen waarop het onderwijs is gericht. Zij kunnen onderzoek verrichten en overdracht van kennis aan de maatschappij bevorderen, voor zover dit verband houdt met het onderwijs aan de instelling. De instellingen hebben tevens, zoveel mogelijk in onderlinge samenwerking en in samenwerking met derden, tot taak de verzorging van post Hoger Beroepsonderwijs.

In deze studie is met name de wettekst die handelt over de relatie van het $\mathrm{HBO}$ en zijn omgeving van belang. Hoofdstuk VIII van de Wet op de $\mathrm{HBO}$ gaat (onder de titel "Relatie HBO-maatschappij") in op het fenomeen van de beroepenveldcommissie. Deze commissie heeft tot taak de minister van advies te dienen omtrent de eisen waaraan - gelet op de behoeften van de maatschappij - de afgestudeerden van die studierichtingen of opleiding naar haar oordeel moeten voldoen. De adviezen aan de minister worden door hem openbaar gemaakt.

In de Wet op het HBO wordt in artikel 109 ingegaan op het HBO-plan. Dit is een door de minister vast te stellen ontwikkelingsplan dat een verslag van de recente, doorgemaakte ontwikkeling biedt en een overzicht geeft van omstandigheden die voor het te voeren beleid ten aanzien van het HBO relevant zijn. Ook een inzicht in de belangstelling van aanstaande studenten én de maatschappelijke behoeften aan in het Hoger Onderwijs afgestudeerden maakt er deel van uit. Dit laatste aspect is in het licht van de discussie over de verhouding van onderwijs en omgeving van betekenis.

De expliciete aandacht in de wet voor het $\mathrm{HBO}$ laat onverlet, dat het $\mathrm{HBO}$ geen eiland is en nooit een eiland is geweest. Het HBO heeft, van oudsher, een natuurlijke verbinding met het werkveld; er zijn stagecontacten, het docentencorps is voor een deel direct in de praktijk werkzaam, in de besturen participeert de praktijk en er zijn gestructureerde contacten in overleggroepen, beleidscomités en overlegvormen met het werkveld. 


\subsubsection{Toekomstig Hoger Onderwijs in discussie}

In het hoger beroepsonderwijs zijn de afgelopen jaren op nagenoeg elk belangrijk terrein fundamentele veranderingen opgetreden. De wet- en regelgeving is gebeel nieuw. Er is een nieuw bekostigingssysteem ingevoerd. Het rechtspositie-systeem is vernieuwd. De institutionele vormgeving van het $\mathrm{HBO}$ is door het STC-proces drastisch veranderd. Er is kortom een HBO-nieuwe stijl. Deze juridische, financiële en institutionele omwentelingen waren en zijn bedoeld ter kwalitatieve verbetering en vernieuwing van het HBO (Hoop, 1988). Het Hoger Beroepsonderwijs is sterk in discussie. De herstructurering van het $\mathrm{HBO}$ is omvangrijk geweest en middels experimenten werden de meest wenselijke vormen en richtingen van het HBO beproefd. Mc Daniel (1984, p.7) stelt dat volgens door hem geraadpleegde experts blijkt, dat het ideaal van een totale integratie van HBO en WO, niet langer uitgangspunt voor de toekomstige ontwikkeling dient te zijn. Wèl lijken een versterking van de coördinatie van $\mathrm{HBO}$ en WO (in de vorm van dienstverlening) en een ontwikkeling naar integratie van vergelijkbare $\mathrm{HBO}$ - en WO-opleidingen haalbaar. Ook elementen, die in het toekomstig Hoger Onderwijs relevant worden geacht met betrekking tot de inhoud ervan, zijn door Mc Daniel in de beschouwing betrokken. Zo heeft hij een aantal componenten gedefinieerd, waaraan aandacht dient te worden geschonken. Daaruit blijkt dat:

- het HBO zich in de toekomst niet slechts moet richten op parate kennis en operationele vaardigheden;

- de invoering van algemene vakken niet wenselijk wordt geacht;

- er een voorkeur bestaat voor het meer betrekken van belanghebbenden "van buiten" de instellingen voor Hoger Onderwijs (Mc Daniel 1984, p. 16 e.v.).

Het HBO is sterk in verandering. Men kan zich afvragen of de plannen voor de toekomst niet expliciet gericht moeten worden op het nastreven van een verbetering wan de eerdergenoemde externe effecten.

In dat verband wijzen Bevers cs (1981) - in een studie over veranderingen in het onderwijs - op de noodzaak van de coördinatie van het Hoger Onderwijs met de beroepspraktijk en samenlevingseisen en bevelen deze aan in hun onderzoek. In de eerder geciteerde H.O.A.K.-nota (1985) wordt ten aanzien van het aspect "evaluatie en het Hoger Onderwijs" gesteld dat in het huidige systeem van regelgeving de waarborg voor kwaliteit vooral gezocht wordt in regels en procedures van preventieve aard. Volgens de Nota is deze manier van kwaliteitsbewaking onvoldoende effectief gebleken. "Voor de processen in het hoger onderwijs en voor de uitkomst daarvan heeft - mede daardoor - 
minder expliciete aandacht bestaan dan op grond van overwegingen van kwaliteitsbewaking tegenwoordig als wenselijk wordt beschouwd". Met name de term "de witkomst" in dit citaat is van betekenis, omdat zij verwijst naar het externe effect van onderwijsinvesteringen en -verbeteringen.

Ook stelt de H.O.A.K.-nota de vraag of de instellingen yoor Hoger Onderwijs thans in staat zijn om slagvaardig aan te sluiten bij en te anticiperen op nieuwe ontwikkelingen en of het Hoger Onderwijs voldoende aansluiting op de arbeidsmarkt kan realiseren. De nota schetst enkele hoofdlijnen van een pluriforme en gedecentraliseerde beleidsworming, waarbij wordt voorzien in een vermindering van voorschriften van overheidswege en een versterken van andere vormen van de kwaliteisbewaking. Deze worden door middel van evaluatie in thet Hoger Onderwijs dusdanig vorm gegeven dat een zo groot mogelijke betrouwbaarheid wordt gerealiseerd. De autonomie van de instellingen voor $\mathrm{HBO}$ zal door de nieuwe $\mathrm{HBO}$-wet aanmerkelijk worden vergroot. De instellingen voor HBO zullen, in de toekomst, in staat gesteld worden slagvaardiger te reageren op wijzigende omstandigheden of inzichten; zij zijn immers vrij het onderwijs te structureren en er inhoud aan te geven.

Verder wordt in de nota (die expliciet spreekt over evaluatie als zorg voor het beroepenveld) gesteld dat bij de evaluatie van het Hoger Onderwijs in toenemende mate ook de afnemers van de produkten, met name de beroepspraktijk betrokken moeten worden. De beroepspraktijk zou in staat moeten worden gesteld wensen te formuleren terzake van vernieuwingen in de onderwijsprogramma's gelet op de beroepskwalificaties van afgestudeerden.

Ook hier zien we de tendens om de externe wereld een grotere invloed en betrokkenheid op de interne onderwijsontwikkeling toe te kennen. Deze vergroting van externe invloed kan raken aan het eerder besproken aspect van de autonomie van het onderwijs (vgl. hoofdstuk 4).

Omgevingsinvloeden en autonomie lijken op gespannen voet te staan. De externe gerichtheid van het onderwijs blijkt duidelijk uit de formulering van het huidige en toekomstige wettelijke kader waarbinnen het onderwijs opereert; ze blijkt uit de geformuleerde doelstellingen, de vervlechting van het onderwijs met de onderscheiden beroepspraktijken en uit beschouwingen rond het rendement van het onderwijs.

Het onderwijs opereert aan eén zijde van de relatie; de pluriforme beroepspraktijk aan de andere kant, de roep om aanpassingen en veranderingen is van deze zijde sterk. Vooral van de zijde van het onderwijs worden reactie en actie verwacht.

Van belang is in dit verband de eerder geciteerde nota van de Ministers van Onderwijs en Wetenschappen en van Economische Zaken aan de Voorzitter 
van de Tweede Kamer der Staten Generaal (1985, kamerstuk 19454, Hoger Onderwijs, Technologie en Marktsector) waarmee de relatie tussen onderwijs/ onderzoek enerzijds en de marktsector anderzijds wordt geschetst. Terzake wordt (zie paragraaf 3.1. van de notitie/pag. 5) een aantal ontwikkelingen geschetst. Een daarvan is de verwachting dat de economische functie van onderwijs sterker op de voorgrond zal komen te staan, hetgeen betekent dat een verdergaande afstemming (kwalitatief en kwantitatief) tussen vraag en aanbod te verwachten is. Voorts wordt in de nota (pag. 7) verwacht dat "de betrokkenheid van het bedrijfsleven bij het onderwijs en onderzoek zal toenemen".

De standpuntbepalingen ten aanzien van de nieuwe wettelijke kaders en de toekomst wan het HBO tonen aan dat ook hier sprake is van tal van divergente visies en van duidelijke relaties met de eerdergenoemde aspecten kwaliteit en interactie. De relevantie van de nieuwe ontwikkelingen voor tal van partijen moge blijken uit de maatschappelijke discussies die volgen op beleidsvoornemens van de overheid ten aanzien van het HBO. Gedachten over nieuw HBO en wijzigingen van het $\mathrm{HBO}$ ontstaan zeker niet in vacuüm maar vinden vaak hun oorsprong in ideeën over toekomstige kwaliteit en de in de toekomst gewenste verhouding van onderwijs en beroepspraktijk.

Tal van (beleids)maatregelen zullen repercussies hebben voor de toekomst van het $\mathrm{HBO}$ en voor de vraag welke accenten de output van het HBO zal hebben en hoe de verhouding van HBO-instellingen met hun omgeving zal zijn. Een van de vragen in dit onderzoek is welke visies mensen hebben op mega- trends op lange termijn en welke de samenhang met visies op andere aspecten zal zijn.

\subsection{MEGA-TRENDS VOOR TOEKOMSTIGE ONTWIKKELING}

\subsubsection{Algemene trends}

Aspecten van de toekomst van het onderwijs die samenhangen met structurele veranderingen worden in deze studie beperkt tot enkele trends die zich in de komende jaren zullen aftekenen. Daartoe is - bij gebreke aan empirisch materiaal m.b.t. visies - geput uit futurologische bronnen. Deze geven globale macro-ontwikkelingen weer, waardoor het $\mathrm{HBO}$ - als onderdeel van de samenleving - zal worden beïnvloed. De aanzet daarvoor ligt bij Idenburg (1971), die van het schoolsysteem zegt dat het in de toekomst als een samenhangend en op rationele wijze beheerd systeem zal worden beschouwd. Het beleid in die toekomst kenmerkt zich door een globale strategie die uitgaat van kwantificeerbare veranderingen. 
Als redenen voor deze ontwikkeling noemt hij de toenemende participatie in het onderwijs, de explosieve groei van kennis en het beheer en de overdracht daarvan, alsmede de groeiende noodzaak het onderwijs te individualiseren, zodat iedereen kan leren in het tempo en naar de voorkeur die hem/ haar past. Of, in de woorden van Husén (1970, p. 113 e.v.), "Individualisation in our schools will soon be a necessity, not a luxury".

Uit Naisbitts's Megatrends (1983) zijn de volgende punten relevant als indicatoren voor de maatschappelijke toekomst, waarin ook het onderwijs functioneert:

- Het denken op termijn

Naar de mening van Naisbitt verdringt het lange-termijn-denken het denken van de volgende week/dag/maand. Zijn voorspelling is, dat alleen ondernemingen, die het lange-termijn-denken systematisch tot het hunne maken, zullen overleven. Hij voorspelt dat kleine en middelgrote ondernemingen het op dit punt zullen winnen van grote. Toekomstgerichtheid op zichzelf is al een "sleutel-issue".

Ook door Toffler (1982) is al gewezen op de noodzaak van onderwijs, dat doelstellingen meer aan de toekomst dan aan het verleden ontleent. Betrokken op het onderwijs is bij dit aspect de mate van actieve toekomst-gerichtheid van het onderwijs aan de orde. Met een vergroting van institutionele autonomie als gevolg van decentralisatie is rekening te houden. Substantiële delegatie gaat plaatsvinden van beslissingsbevoegdheid naar afzonderlijke opleidingsinstituten.

- Het zichzelf helpen op grond van hulpverlening door organisaties en instellingen

Mensen nemen steeds meer in eigen hand. We kiezen steeds meer zelf ons voedselpakket, eetgewoonten, bewegingsgedrag. Meer zelfbewustheid in de gezondheidsbeleving leidt tot differentiatie en kleinschaligheid in de nog resterende gezondheidszorg. Gewezen wordt op de noodzaak mensen, in de toekomst in het onderwijs, meer te trainen in het doen van keuzen en in het aangaan van relaties.

\section{- Participatie in plaats van representatie}

De participatietrend zal een hoge vlucht nemen; mensen willen zelf de controle hebben over hun leven. Ieder wil zijn keuzen zelf kunnen maken. De hoofdtrend is de lijn naar participerende democratie, participatie in plaats van representatie, ook op terreinen van onderwijs, werk en woonomgeving. Toffler 
voorziet onderwijs dat mensen leert met veranderingen om te gaan. Betrokken op onderwijstaken is de noodzaak aan de orde in het onderwijs mensen te leren met veranderingen om te gaan en actief te participeren in keuzeprocessen. (Toffler, 1982).

\section{- Netwerken in plaats van hiërarchieën}

Enkele trends (de groei van de informatiesamenleving, de groei van de participatie, neutraliteit en de decentralisatie) leiden onvermijdelijk tot het instorten van hiërarchische structuren, aldus Naisbitt. Informatie wordt een eenvoudig dom beschikbaar goed. Netwerkstructuren zullen een geheel nieuwe attitude in de taakvervulling vragen, immers: "in the network environment, rewards come by emposing, not by climbing over them". (1983, p. 138).

Een gevolg hiervan zijn kleinere, meer herkenbare werkeenheden en ook een meer directe betrokkenheid bij wat men doet, te weten voor wie men het doet (vgl. Rogers en Kincaid, 1981).

Voor het onderwijs geldt als afgeleide functie het mensen voorbereiden op werken in kleinere, meer overzienbare eenheden en op kleinere schaal.

\section{- Van oflof naar enten}

De beslissingen die mensen vroeger namen waren veelal dichotoom. Nu zijn er veel meer opties en keuzemogelijkheden, onder meer blijkend uit mogelijkheden voor parttime werk, gevarieerde en meer individuele vrijetijdsbesteding, pluralistische tendensen in media, kunst, cultuur etc.

\subsubsection{Zeven trends, relevant geacht voor toekomstig $H B O$}

\section{- Het HBO in kleine eentheden}

Toffler (1982) spreekt over onderwijs, dat in de toekomst in kleine overzichtelijke eenheden wordt aangeboden, georganiseerd op regionale schaal. Deze trend lijkt tegenstrijdig met de huidige discussie over schaalvergroting van het HBO. Maar ook het huidige streven naar schaalvergroting gaat overigens uit van een bepaalde wenselijke grootte: het HBO moet een dusdanige omvang hebben dat het regionaal kan functioneren en ook als zodanig herkenbaar is. Door Huber (1985) is een alternatief voor toekomstig Hoger Onderwijs geschetst. Een bestel waarin participatie, betrokkenheid en kleinschaligheid de kernbegrippen vormen. Hij pleit ervoor dat het Hoger Onderwijs ertoe zal komen steun te geven aan alle relaties of interacties tussen de universiteit en de mensen erbuiten, actiegroepen, lokale coöperaties etc., (door middel van extramuraal werk, engagement in lokale leergroepen buiten de universiteit). 


\section{- Het HBO regionaal georganiseerd}

Het in kleine eenheden aanbieden van $\mathrm{HBO}$ wil niet per definitie zeggen dat het daardoor ook regionaal herkenbaar is. Het gaat er dan ook om dat de school kan werken als een integraal onderdeel van haar omgeving. Dit is onder meer mogelijk door het dienstenpakket toegankelijk te maken voor alle leden van de regionale gemeenschap. Het dienstenpakket van een school is in deze zin toegankelijk voor alle leden van een plaatselijke/regionale gemeenschap en het dienstenpakket omvat veel meer dan normale, reguliere onderwijstaken. De school is ook meer open voor mensen die wel onderwijzen maar geen formele onderwijs-status hebben.

De school wordt een centraal element in het leven van een lokale/regionale gemeenschap met als consequentie een sterkere afhankelijkheid van lokaal bestuur (vgl. Shane en Tabler, 1980).

\section{- Toenemende snelheid qua ontwikkeling en flexibiliteit wan het $\mathrm{HBO}$}

De ontwikkelingen in de beroepspraktijk lijken steeds sneller te gaan (vgl. van Bruggen, 1983). De HBO-opleiding staat voor de noodzaak steeds sneller en frequenter de leerplannen te wijzigen, de organisatie aan te passen en de werkwijzen te herzien in het licht van de ontwikkelingen in de beroeps-praktijk. Voor van Bruggen is de toenemende snelheid van de ontwikkelingen in de beroepensfeer een vaststaand gegeven; daardoor zal een tamelijk frequente verandering van leerplanmen, inhouden, organisatiepatronen en werkwijzen in de cursussen noodzakelijk zijn. Hij denkt dat dat meer zal gaan via een systeem van regionale en landelijke professionele samenwerking tussen vertegenwoordigers van het beroepenveld in kwestie en scholen of cursusleiders, dan door nationale regelgeving e.d. Er zal weinig bureaucratisering en formele organisatie van het hier bedoelde beroepenonderwijs zijn, aldus van Bruggen. Deze gedachte sluit aan bij de eerder verwoorde ideeën met betrekking tot gedecentraliseerd en geindividualiseerd onderwijs.

\section{- Individualisering en decentralisatie}

"Decentralisation creates more centers. That means more opportunities for individuals" (Toffler, 1982, pag. 178). Decentralisatie leidt tot vergroting van de institutionele autonomie. De beslissingsbevoegdheid wordt gedelegeerd naar de afzonderlijke opleidingsinstituten, die daarmee meer mogelijkheden krijgen het onderwijs in te richten naar de eisen van de voor hen relevante beroepspraktijk. De lokale krachten zullen het, aldus Toffler, winnen van nationale invloeden, nationale politiek en nationale media. Ook de noodzaak om te komen tot frequente verandering van leerplannen, organisatiepatronen en werkwijzen en de plaats waar het beroepsonderwijs wordt gegeven, is hierbij essentieel. 
Verwacht wordt dat het beroepsonderwijs ten dele in de beroepsuitoefening zelf zal kunnen plaatsvinden (in de worm van leercontracten, stage-overeenkomsten e.d.). Een van de trends is dat onderwijs in de toekomst gedestandaardiseerd moet worden en veel meer op individuele kwalificatie-wensen toegesneden moet worden. Kan het zo zijn dat het hogere beroepsonderwijs sterker dan nu reeds het geval is, gedeeld zal zijn in cursussen van kortere en langere duur, die niet meer per definitie in één school zullen worden gevolgd? Een sterke differentiatie wordt verwacht, waarbij de leerling zich een kwalificatie verwerft door het verzamelen van een aantal certificaten uit cursussen en andersoortige activiteiten (vgl. Bevers, e.a., 1981).

Flexibiliteit van het $\mathrm{HBO}$, (inspelend op het steeds wisselende werkveld) wordt als groot voordeel in de toekomst gezien; het diploma wordt een dossier, dat alle beroepsoriënterende en beroepsspecifieke delen omvat.

\section{- Meer specifiek of meer algemeen HBO in de toekomst?}

Hierbij gaat het om de vraag wat de verhouding moet zijn tussen algemeen vormende vakken en specifiek beroepsgerichte vakken. Van Bruggen voorziet bij het hoger onderwijs dat ongeveer een kwart van de totaal beschikbare tijd gebruikt zal worden voor "studium generale".

Daarnaast is het aspect van de opstelling van het $\mathrm{HBO}$ van belang, dat wil zeggen de mate van pro- of re-activiteit: Moet het HBO meer gericht zijn op vernieuwing van de werksector middels zijn eindprodukt (....) of moet het beroepsonderwijs in de toekomst meer re-actief reageren op ontwikkelingen in de werksector en vooral de ontwikkelingen daarin tot voornaamste uitgangspunt maken? Bevers c.s. (1981) wijzen er in dit verband op dat de praktijk/beroepsgerichtheid van de opleiding op zichzelf veel aandacht krijgt bij het denken over vernieuwing van onderwijs.

\section{- De toename van "experiential education"}

"Experiential education" omvat onderwijsactiviteiten die buiten de onderwijsinstellingen plaatsvinden, maar waarvan de doelstellingen vooraf door de instellingen zijn geformuleerd. Hieronder vallen stages, veldwerk en assistentschappen. De activiteiten worden beoordeeld op hun werkelijkheidskarakter en het niveau, dat moet zijn afgestemd op het niveau dat geldt voor werknemers in de betreffende situatie.

\section{- Meer invloed van studenten}

Eide (1983) schetst de ontwikkeling van de "cliënt"-revolutie. Het onderwijs richt zich in toenemende mate op de interesse van echte cliënten, i.c. de studenten. Hij ziet als mogelijke toekomstontwikkelingen - in verbinding met alternatieve informatiemedia, de "cliënt-revolutie" en claims op participatie in 
andere delen van de samenleving - dat het waarschijnlijik is te achten dat onderwijsinstellingen in de toekomst hun onderwijs meer richten op de interessen van hun echte cliënten, i.c. de studenten.

"Reeds nu immers zien we dat het onderscheid tussen deze twee stromen in de onderwijs-stelsels van de geindustrialiseerde landen aan het vervagen is en in toenemende mate gezien wordt dat mengvormen in het algemeen de leerlingen meer kansen bieden om zichzelf het pakket kwalificaties te verwerven dat voor de leerling in kwestie het best lijkt". (vgl. Eide, 1983, p. 13).

\subsection{SAMENVATTING}

In het bestek van dit hoofdstuk werd het nieuwe kader voor toekomstig HBO geschetst. Daarnaast werden enkele mega-trends voor toekomstige ontwikkeling weergegeven. Zeven trends ontleend aan de literatuur en resultaten van toekomstonderzoek, zijn geschetst in onderstaand overzicht.

Tabel 6: Weergave van de elemenren m.b.t. Structuar en Organisatie

\begin{tabular}{ll}
\hline Domein & Structuur en organisatie \\
\hline Subdomein & $\begin{array}{l}\text { Ontwikkelingen m.b.t. de organisatiestructuur van het HBO } \\
\text { Element }\end{array}$ \\
$\begin{array}{ll}\text { 1. De visies op kleine organisatorische eenheden } \\
\text { 2. De regionale inbedding van het HBO }\end{array}$ \\
$\begin{array}{ll}\text { Subdomein } & \text { Ontwikkelingen m.b.t. het karakter van het HBO } \\
\text { Element } & \text { 3. Snelheid en flexibiliteit m.b.t. externe ontwikkelingen } \\
& \text { 4. Individualisatie/decentralisatie } \\
\text { Subdomein } & \text { Owerige ontwikkelingen } \\
\text { Element } & \text { 6. Experiential education }\end{array}$ \\
\hline
\end{tabular}

De zeven elementen zijn, werder gedetailleerd in de vragenlijst opgenomen.

Wij sluiten met dit hoofdstuk de theoretische analyse af en vervolgen met het verslag van het empirische deel van dit onderzoek, zoals dat in de hoofdstukken 6 tot en met 8 zijn beslag zall krijgen. Nadat de probleemstelling en onderzoeksopzet worden besproken (hoofdstuk 6) wordt in hoofdstuk 7 ingegaan op het onderzoek naar de conceptuele systemen die informanten hanteren bij het beoordelen van kern-aspecten uit deze studie. De vraag welke denkkaders mensen hanteren en wooral of er verschillende "frame-works" zijn tussen subgroepen is daarbij essentieel.

Hoofdstuk 8 gaat in op verschillen in visies die - onafhankelijk van identieke of verschillende denkkaders - kunnen optreden. 


\section{Probleemstelling en onderzoeksopzet}

\subsection{INLEIDING}

Thans volgt de beschrijuving van de probleemstelling en de opzet van het uitgevoerde onderzoek. De instrumentconstructic en het survey-onderzoek worden daarin besproken naast de formatie van de informantengroep op basis van een vooronderzoek. De belangrijkste gegevens rond afname en dataverzameling van het survey-onderzoek en de kenmerken van de respondentengroep besluiten dit hoofdstuk.

\subsection{PROBLEFMSTELLING}

\subsubsection{Karte beschrijuing}

Ons onderzoek vertrekt vanuit een praktisch standpunt. In tal van beschouwingen en beleidsdiscussies worden vele opinies met betrekking tot de relatie van onderwijs en beroepspraktijk verwoord. Het doel van dit onderzoek is een beschrijwing te geven van de visies op de gewenste kwaliteit van de $\mathrm{HBO}$ output, de gewenste aard van de interactie en de gewenste structurele ontwikkeling van het $\mathrm{HBO}$ in de toekomst. Daarnaast is de vraag van belang in hoeverre er verschillen en overeenkomsten bestaan tussen de visies van de diverse groepen relevante actores.

Relevante actores zijn mensen uit de beroepspraktijk, het onderwijs en de intermediaire organisaties die op grond van hun kennis of kunde betrokken zijn bij de discussie over de aansluitingsproblematiek tussen onderwijs en beroepspraktijk.

Hoofdstuk 3 handelde over het begrip kwaliteit van de HBO-output, dat werd opgesplitst in twee dimensies: de sociaal-normatieve kwalificaties en de "technisch-instrumentele" kwalificaties. De eerste dimensie omvat zes elementen, de tweede vijf. Aan deze elf elementen zijn er drie toegevoegd (zie bijlage I: Over- 
zicht theoretische operationalisatie en empirische reductie). In hoofdstuk 4 is de problematiek van de interactie geschetst. Het op elkaar betrokken zijn van HBO en beroepspraktijk is gezien langs de dimensies pro- en re-activiteit van het $\mathrm{HBO}$ en de professionalisatie van de beroepspraktijk. In de operationalisatie van het begrip interactie zijn drie aspecten van het $\mathrm{HBO}$, drie aspecten van de beroepspraktijk en twee aspecten van het overleg opgenomen (zie bijlage I). In hoofdstuk 5 zijn vervolgens zeven trends voor de toekomstige ontwikkeling van het HBO beschreven, zoals die door diverse auteurs worden verondersteld.

De probleemstelling, die ten grondslag ligt aan dit onderzoek, luidt als volgt:

Welke visies hanteren informanten uit de beroepspraktijk, het onderwijs en de intermediaire organisaties, als zij spreken over de gewenste kwaliteit van de HBO-opbrengst, de gewenste aard van de interactie tussen $H B O$ en beroepspraktijk, alsmede de gewenste stnuctuur en organisatie? In welke mate vertonen de visies een onderlinge samenhang en welke verschillen en overeenkomsten zijn er?

De kwaliteit van toekomstig $\mathrm{HBO}$ en de discussies daarover waren het vertrekpunt. Bij de beoordeling van die kwaliteit zijn twee partijen essentieel: de mensen in de - pluriforme - beroepspraktijk en degenen die in de onderwijspraktijk werken aan de vormgeving en de concretisering van de onderwijstaak en -doelstelling. Deze indeling voegt een tweede aspect toe aan de vraagstelling. Hoe verhouden zich beide, vanuit tal van opzichten verschillende, praktijken thans en hoe zou de interactie er in de toekomst uit moeten zien? $\mathrm{Nu}$ zijn zowel de vormgeving van de onderwijspraktijk als de vormgeving van de beroepspraktijk moeilijk voorspelbaar. Wat vaststaat is een tijd vol verandering en ontwikkeling. Wettelijke kaders die ook voor de toekomst relevant zijn, zijn in voorbereiding; de zorg voor de vormgeving van onderwijsstructuur is ook de zorg van velen die niet tot het geinstitutionaliseerde onderwijs zelf behoren. Dit gegeven voegt een derde aspect toe dat voor Hoger Beroepsonderwijs in de toekomst een rol speelt.

In dit onderzoek wordt het denken over de toekomst gespecificeerd naar:

- de gepercipieerde aansluiting zoals die tussen onderwijsaanbod en arbeidsvraag i.c. visie op gewenste kwalificaties van de abituriënten in de toekomst kan bestaan;

- de relatie tussen de partijen i.c. de interactie van onderwijs- en beroepspraktijk, zoals die kan bestaan in de toekomst;

- enkele structuurkenmerken en globale trends in de toekomstige ontwikkeling van het $\mathrm{HBO}$ als organisatie. 


\subsubsection{De positie van de respondenten/verschillen in kaders}

De betekenisgeving aan toekomstig gewenste ontwikkelingen in relatie tot deze drie kernaspecten werd vooral afhankelijk geacht van de positie van de respondenten. De aspecten zijn, als wij spreken over de subgroepen van experts, voorwerp van (veelal) afzonderlijke ervaring van groepen van respondenten. Aangenomen werd dat bij de vanuit het onderwijs betrokken respondenten een ander kader van referenties leeft, dan bij degenen die vanuit de beroepspraktijk met onderwijsvraagstukken zoals bovenbedoeld in aanraking komen. Het verschil in functies van de kaders wordt essentieel geacht: bij onderwijs zijn individuele ontplooiing en beroepservaring primair.

Op de arbeidsplaats telt primair de produktie van goederen en/of diensten en de bruikbaarheid van door het onderwijs opgeleide abituriënten om hieraan concreet te werken.

Een ander punt, met betrekking tot de geschetste driedeling kwaliteit, interactie en structuur, is dat deze concepten niet moeten worden gezien als losstaande, gelijkwaardige kaders van beoordeling.

Wij hebben als uitgangspunt genomen dat kwaliteit van de output het kernthema is in de interactie. Het oordeel dat men daarover velt, leidt tot ideeën en opvattingen, o.a. met betrekking tot een toekomstige structuur van het $\mathrm{HBO}$ (dat in de visie van de respondenten een oplossing vormt voor de problemen die men nu in de "kwaliteit van de output" onderkent).

Deze driedeling vormt het vertrekpunt voor het onderzoek. De visie komt tot stand doordat men oordeelt over "kwaliteit" en "structumr". Vatten wij nu de twee thema's samen in het begrip interactie, dan lijkt het aspect interactie zowel oorzaak als gevolg van een bepaalde visie op te leveren.

Het onderzoek heeft geen voorspellende intenties; het is de samenvatting van de wenselijkheid die experts afzonderlijk aan - mogelijke - toekomstige ontwikkelingen toekennen. Het gaat na hoe de toekomst eruit zou moeten zien volgens de perceptie van degenen die bij het voorwerp van de studie zowel betrokken zijn als over een zekere reputatie op het terrein van de relatie van onderwijs en arbeid beschikken.

\subsection{DE INSTRUMENTCONSTRUCTIE}

Voor het opsporen van visies van informanten is een vragenlijst ontworpen die schriftelijk werd afgenomen. De lijst bevatte 99 uitspraken waarwan (middels 5 punts-schalen) de per individu toegekende mate van wenselijkheid c.q. 
betrokkenheid kon worden aangegeven, en een aantal anderszins woorgecodeerde vragen. De items betroffen in total 5 concepten zoals blijkt uit de volgende tabel.

Tabel 7: Alard en aantal items in de vragentijst naar concept

\begin{tabular}{lcl}
\hline concept & aantal items: & karakter: \\
\hline - kwaliteit & $53 / 9^{*}$ & 5 punts-schaal \\
- interactie & 16 & 5 punts-schaal \\
- structuur en organisatie & 18 & 5 punts-schaal \\
\hline - eigen visie op invloed en betrokkenheid & 3 & 5 punts-schaal \\
- respondentkenmerken (persoonsgebonden/positioneel) & 10 & voorgecodeerd \\
\hline Totaal & 109 items & \\
\hline
\end{tabular}

(* 9 items zijn een directe, 53 een indirecte meting van kwaliteit)

\subsubsection{Operationalisering van de elementen kwaliteit, interactie, structuur en} onganisatie

De items zijn voorgelegd als uitspraken over kwaliteit, interactie en structuuraspecten. Per statement kan de toegekende mate van wenselijkheid worden aangeven. Elk statement - ontleend aan discussies (in de literatuur, via media of in fora) drukt een bepaalde sociale definitie van de realiteit uit en geeft een bepaalde wenselijkheid van de respondent op specifieke aspecten weer (Felling e.a. 1983, pag. 60 e.v.). Voor een inhoudelijke weergave van de elementen zoals geoperationaliseerd zij verwezen naar hoofdstuk 3 tot en met 5 .

Daarnaast is informatie verzameld over de volgende karakteristieken van informanten:

\section{Positionele en persoonskenmerken:}

- de leeftijd;

- het opleidingsniveau en de opleidingsrichting;

- de vraag of de sector van werkzaamheid conform de sector van opleiding was;

- de duur van de werkzaamheden in de sector;

- de duur van bet totale arbeidsverleden;

- in welke sector men werkzaam was (onderwijs-arbeid-intermediaire sector); 
- de concrete functie in de sector;

- in welke subsector men werkzaam was;

- de grootte van het bedrijf of de instelling waar men werkzaam was.

De antwoorden laten het schetsen van een gedifferentieerd beeld (b.v. qua opleidingsniveau en -richting) toe en maken clustering van subgroepen mogelijk. De positionele kenmerken zijn opgenomen om te onderzoeken of de plaats waar men maatschappelijk en beroepsmatig functioneert, in de beoordeling van betekenis was.

\subsubsection{Operationalisering van participatie en invloedsuitoefening in beleids- ontwikkeling}

De drie items geven aan of respondenten zelf van mening zijn dat ze inwloed hebben op het toekomstig $\mathrm{HBO}$ en of respondenten praktisch en regeimatig betrokken zijn bij discussie en concrete beleidsontwikkeling ten aanzien van het toekomstig HBO.

Gevraagd is:

- in welke mate de respondent denkt beslissende invloed te hebben op de belleidsvoorbereiding en besluitvorming;

- in welke mate de respondent zichzelf betrokken voelt bij de beleidsontwikkeling in de overleggremia;

- in welke mate de respondent betrokken is bij discussies over bet HBO en de beroepspraktijk.

\subsection{DE FORMATIE VAN DE RESPONDENTENGROEP}

\subsubsection{Positionele en reputatiebenadering bij de steekproefsamenstelling}

Binnen de provincie Limburg is nagegaan wie als respondent zou kunnen fungeren. De populatie van het onderzoek is de kring van personen, die op enigerlei wijze betrokken is bij de discussie over de aansluiting van het HBO en de beroepspraktijk.

Het op enigerlei wijze betrokken zijn kan op velerlei wijze gerealiseerd worden. Allereerst komen in aanmerking degenen die officiële posities bezetten in de drie onderscheiden sectoren. Op grond van deze posities mag verwacht worden dat zij betrokken zijn bij de discussies over de relatie $\mathrm{HBO}$ en ar- 
beidsmarkt. Het opsporen van mensen op officielle posities - binnen de sectoren - is echter niet de enige methode die wij gehanteerd hebben ter bepaling van de groep van relevante informanten. Wij hebben daarnaast gebruik gemaakt van de reputatiemethode via de sneeuwbaltechniek.

Doorgaans wordt voor het vaststellen van invloedrijke personen een drietal methoden gehanteerd: de reputatie-, de decisie- en de positionele methode (zie Felling, 1974a, pp 19 e.v.). In onze studie is een combinatie van de positionele- en de reputatiemethode gevolgd om de informantengroep te bepalen. Wij zullen thans de methodiek van de reputatiemethode beschrijven en het aandeel van de positionele methode schetsen.

Het werd van belang geacht vast te stellen wie binnen het territorium van het onderzoek de reputatie had een expert te zijn.

Het idee was via een sociometrische techniek diegenen op het spoor te komen die de reputatie hadden, invloed uit te oefenen op het vraagstuk dat in het onderzoek centraal stond. Wie is - in de ogen van anderen - relevant voor het probleem? Deze vraag is beantwoord in een vooronderzoek. Het criterium voor het invullen van een naam daarbij was de kennis/kunde/betrokkenheid bij het onderwerp HBO en beroepspraktijk. Aan informanten werd verzocht aan te geven wie op grond daarvan bij een dergelijk onderzoek geraadpleegd zou moeten worden. Dit gegeven was het uitgangspunt voor de samenstelling van de informantengroep. Vandaar dat de keuze is gemaakt voor het verzamelen van informanten middels een combinatie van twee van de drie eerdergenoemde methoden. Deze combinatie heeft als volgt plaatsgevonden:

fase $1 \mathrm{Bij}$ het bepalen van de startgroep voor de reputatiemethode zijn mensen op officiële posities geïdentificeerd en benaderd (positie als startpunt woor reputatie-onderzoek).

fase 2 De in fase 1 gegenereerde namen vormden een bestand aan potentiële informanten, dit werd aangevuld tot de definitieve steekproef (positie als selectiecriterium, aanvullend op de resultaten van het reputatieonderzoek).

fase 3 Tijdens het survey zijn enkele open vragen gesteld over het aspect "reputatie van anderen". De resultaten daarvan zijn aanvullend gebruikt ten opzichte van de eerste uitkomsten van het reputatie-onderzoek. Ze leidden in enkele gevallen tot uitbreiding van de steekproefpopulatie en nazending van enquêtes (survey resultaat, aanvullend ten opzichte van het initiële reputatieonderzoek). 


\subsubsection{De sneeuwbaltechniek in de reputatie-methode}

Er is een bestand van adressen geformuleerd van een initiele groep, gerecruteerd uit de sectoren arbeid, onderwijs en intermediaire organisaties, gelet op de posities die $z \ddot{j}$ in die sectoren innamen en in of vanuit die sectoren bekleedden. $\mathrm{Zij}$ waren:

- betrokken bij fora, owerlegwormen gericht op de relatie onderwijsarbeid of

- bij koepels, verbanden, verenigingen of

- maakten deel uit van samenwerkingskaders binnen het HBO.

Zij waren werkzaam in de sectoren:

- Onderwij: Het HBO in Limburg en verbanden werkzaam ten behoeve van het $\mathrm{HBO}$ en samengesteld uit representanten van het $\mathrm{HBO}$.

Bij deze sector is gevraagd om medewerking van directie, leraren en bestuurslleden. Dat het HBO benaderd moest worden behoeft geen nader betoog. Het onderzoek werd verricht bij alle $\mathrm{HBO}$-instellingen en samenwerkingsverbanden voor het HBO. Daarnaast kwamen in aanmerking HBO-representanten in provinciale werkgroepen gericht op de aansluiting van onderwijs en arbeid en Euregionale groepen voor onderwijs en scholing.

- Arbeid: instellingen, ondernemingen en organisaties van werkgevers en werknemers en verbanden samengesteld uit representanten van deze sector. Medewerking is gevraagd van directie/managers/leidinggevende functionarissen en personeels- en beleidsfunctionarissen. Voor namen en adressen van organisaties werd een selectie gemaakt wit:

- grote bedrijven (overheid, welzijn, dienstverlening, industrie, gezondheidszorg) i.c. de "TOP-50" van het Limburgse bedrijfsleven qua bezette arbeidsplaatsen;

- de Raad voor de Arbeidsmarkt;

- middellgrote bedrijwen;

- verenigingen voor werkgevers en werknemers;

- Kamers van Koophandel;

- de personeelschefs van Limburgse Gemeenten;

- de leden van de Limburgse Vereniging voor Personeelsbeleid;

- het ambtelijke apparaat der provincie.

Bij de benadering van deze sector werd een gestratificeerde, a-selecte steekproef getrokken uit het bestand van bedrijven opgenomen in het vestigingsregister Limburg. De steekproef betrof 219 adressen op een totaal van 451 , 
zijnde alle bedrijven met meer dan 100 werknemers, waarbij in de steekproeftrekking de verdeling over bedrijfssectoren en grootteklassen werd aangehouden. De minimumgrootte van 100 is aangehouden in verband met de grotere kans op aanwezigheid van opleidings- en personeelsfunctionarissen.

- Intermediaire organisaties: instellingen werkzaam met beroepskrachten op het gebied van de overgang van school en werk, alsmede fora gericht op het verbeteren van de aansluiting.

Gevraagd is naar response van leidinggevende en uitvoerende krachten alsmede bestuursleden van instellingen. Benaderd zijn de perifere organen van Arbeidswoorziening, het Contactcentrum Onderwijs en Arbeid inclusief de regionale afdelingen daarvan, de projecten voorlichting schoolverlaters, de bureaus voor school- en beroepskeuze in de provincie en instituten voor onderzoek, overleg en samenwerking met provinciale betekenis.

De intermediaire organisaties hebben ten doel bij te dragen aan de relatie van onderwijs en arbeid, danwel leerlingen/volwassenen voor te bereiden op en te helpen bij hun entree op de arbeidsmarkt. Kwalificatie in de beroepsopleiding, het beroepsonderwijs, beroepenvelden en de ontwikkeling daarbinnen, zijn hier voorwerp van dagelijkse ervaring.

De reputatie-methode, in haar oorspronkelijke vorm, gaat ervan uit dat iedere persoon die niet in de startpopulatie is opgenomen en na de eerste reactie wordt genoemd ook de vraag naar het noemen van namen krijgt voorgelegd. Men noemt deze manier van werken ook wel de "sneeuwbalprocedure" (vgl. Felling 1974a, Rogers en Kincaid 1981). Wij zijn - op praktische gronden enigszins afgeweken van deze werkwijze. Slechts wanneer een naam meer dan eenmaal was genoemd en niet in de startpopulatie was opgenomen, dan werd de genoemde ook een vooronderzoekformulier gezonden met het verzoek - op zijn of haar beurt - namen te noemen.

De resultaten waren zoals hieronder weergegeven:

Tabel 8: Overzicht van startpopulatie en respons gespecificeerd naar sectoren

\begin{tabular}{lccc}
\hline Sector & $\begin{array}{c}\text { A } \\
\text { startpopulatie o.g.v. } \\
\text { positionele methode }\end{array}$ & $\begin{array}{c}\text { B } \\
\text { respons qua } \\
\text { formulieren }\end{array}$ & $\begin{array}{c}\text { C } \\
\text { respons qua genoemde } \\
\text { relevante actores }\end{array}$ \\
\hline Arbeid & 219 & 168 & 355 \\
Onderwijs & 55 & 52 & 208 \\
Intermediair & 28 & 27 & 40 \\
\hline Totaal & 302 & 247 & 603 \\
\hline
\end{tabular}




\section{Toelichting:}

In totaal werden 302 vooronderzoekformulieren uitgezet (kolom A). Op de 247 terugontvangen formulieren (kolom B) werden 603 namen genoemd. Deze zijn onder kolom $\mathrm{C}$ weergegeven, verdeeld over de drie sectoren.

De frequentie waarmee mensen cloor anderen werden genoemd, is de voornaamste indicator voor de reputatie (in netwerkanalytische termen heet dit de ingraad). Daarbij is onderscheid gemaakt tussen de groep mensen die slechts eenmaal genoemd worden (ingraad $=1$ ) en de groep mensen die minimaal tweemaal genoemd worden (ingraad $\geq 2$ ). De ingraadverdeling per sector is weergegeven in tabel 9.

Tabel 9: Genoemde namen en ingraadverdeling gespecificeerd per sector:

\begin{tabular}{lccr}
\hline Sector & Aantal namen & Ingraad $\geq 2$ & Ingraad 1 \\
\hline Arbeid & $355(100 \%)$ & $67(19 \%)$ & $288(81 \%)$ \\
Onderwijs & $208(100 \%)$ & $66(32 \%)$ & $142(68 \%)$ \\
Intermediair & $40(100 \%)$ & $16(40 \%)$ & $24(60 \%)$ \\
\hline Totaal & $603(100 \%)$ & $149(25 \%)$ & $454(75 \%)$ \\
\hline
\end{tabular}

\subsubsection{Aanvullend gebruik van de positiemethode voor de steekproefbepaling}

De personen met een minimale ingraad van 2 vormden de primaire steekproef voor het survey-onderzoek. Er was sprake van relatieve onder- c.q. oververtegenwoordiging binnen de afzonderlijke sectoren. De ingraadverdeling week af van relevante subsectoren binnen de drie sectoren arbeid, onderwijs en intermediaire organisaties.

Daartoe zijn aan de groep van 149 personen (met een ingraad $\geq 2$ ) a-select personen toegevoegd met ingraad 1 of 0 uit het vooronderzoek. Dit gelet op het bereiken van een zodanige verdeling van potentiële informanten voor het survey dat alle relevante subsectoren werden benaderd. De groep van 203 personen is a-select getrokken uit de namen met een ingraad 1 of 0 die voorkwamen binnen de bestanden geformeerd per subsector. Een subsector was binnen de arbeidsorganisaties gespecificeerd naar de codes uit het Standaard Beroepen Informatie-systeem; binnen het onderwijs naar de richting van het onderwijs (technisch, sociaal-pedagogisch etc.) en binnen de intermediaire organisaties naar "COA" en "overigen".

In de enquête in het kader van het survey-onderzoek, hebben wij aan de respondenten verzocht namen te noemen van personen waarmee zij feitelijk 
contact onderhouden inzake de aansluitingsproblemen van onderwijs en beroepspraktijk. Wij beogen daarmee een controle uit te kumnen voeren op de gegevens uit het vooronderzoek.

Indien er veel nieuwe namen genoemd worden dan moeten we twijfelen aan de reputatie-methode, omdat deze methode kennelijk niet alle experts heeft opgespoord. Anderzijds biedt ons dit de mogelijkheid nieuw genoemde personen alsnog te benaderen met de enquête. Wij vinden voldoende steun voor de opvatting dat het vooronderzoek een adequaat beeld geeft van de "experts". $\mathrm{Er}$ is slechts een klein aantal nieuwe namen genoemd. In de sector arbeid werden met een ingraad 2 of meer, 14 nieuwe namen genoemd, in de sector onderwijs 12 namen en in de sector intermediaire organisaties 1 naam.

Daarnaast werd een aantal personen uit het vooronderzoekbestand die niet in de oorspronkelijke steekproef zijn opgenomen, in de enquête opnieuw genoemd (in technische termen komt dit erop neer dat de ingraad van de desbetreffende personen hoger wordt). Ook deze personen is alsnog een enquête-formulier toegezonden. In de sector arbeid betrof dit 1 persoon, in de sector onderwijs 13 personen en in de sector intermediair 2 personen. Het in totaal uitgezette aantal enquêtes kwam daarmee op 493 . Dit hebben wij in de volgende tabel samengevat.

Tabet 10: Uitgezetse enquêtes o.g.v. ingraad $\geq 2$ (A), inclusief nazending (B), ingraad 1 (C) en ingraad $0(D)$

\begin{tabular}{|c|c|c|c|c|c|c|}
\hline & $\begin{array}{c}\text { A } \\
\text { Ingraad } \geq 2\end{array}$ & $\begin{array}{c}\mathrm{B} \\
\text { Nazending }\end{array}$ & $\begin{array}{l}\text { Totaal } \\
\text { Ingraad } \geq 2\end{array}$ & $\begin{array}{c}\text { C } \\
\text { Ingraad } 1\end{array}$ & $\begin{array}{c}\mathrm{D} \\
\text { Ingraad } 0\end{array}$ & Totaal \\
\hline Arbeid & 67 & 15. & 82 & 120 & 111 & 313 \\
\hline Onderwijs & 66 & 25 & 91 & 26 & 9 & 126 \\
\hline Intermediair & 16 & 2 & 18 & 15 & 21 & 54 \\
\hline $\begin{array}{l}\text { Totaal } \\
\text { In } \% \%\end{array}$ & 149 & 42 & $\begin{array}{l}191 \\
(38,8)\end{array}$ & $\begin{array}{l}161 \\
(32,6)\end{array}$ & $\begin{array}{l}141 \\
(28,6)\end{array}$ & $\begin{array}{c}493 \\
(100)\end{array}$ \\
\hline
\end{tabular}

\section{Toelichting:}

Het totaal aantal personen benaderd met een postale enquête is: 493 .

- daarvan had uit het vooronderzoek ingraad $\geq 2: 149$

- uit het survey ingraad $\geq 2$

$:+42$

- Totaal ingraad 2

: 191

- daarvan had ingraad 1 of 0

: 302

Door de combinatie van reputatie- en positiemethode is de a-selectheid van de keuze van de 302 benaderde informanten gewaarborgd. Zij beschikten over 
ingraad 1 of 0 (resp. 161 en 141 personen). In beide gevallen diende de selectie ertoe een steekproefbestand op te bouwen dat in totaliteit redelijk verdeeld was over de relevante subsectoren binnen de hoofdgroepen Arbeid, Onderwijs en Intermediaire Organisaties. Onderstaand schema 3 geeft de gevolgde procedure weer:

Schema 3: Overzicht procedure vooronderzoek

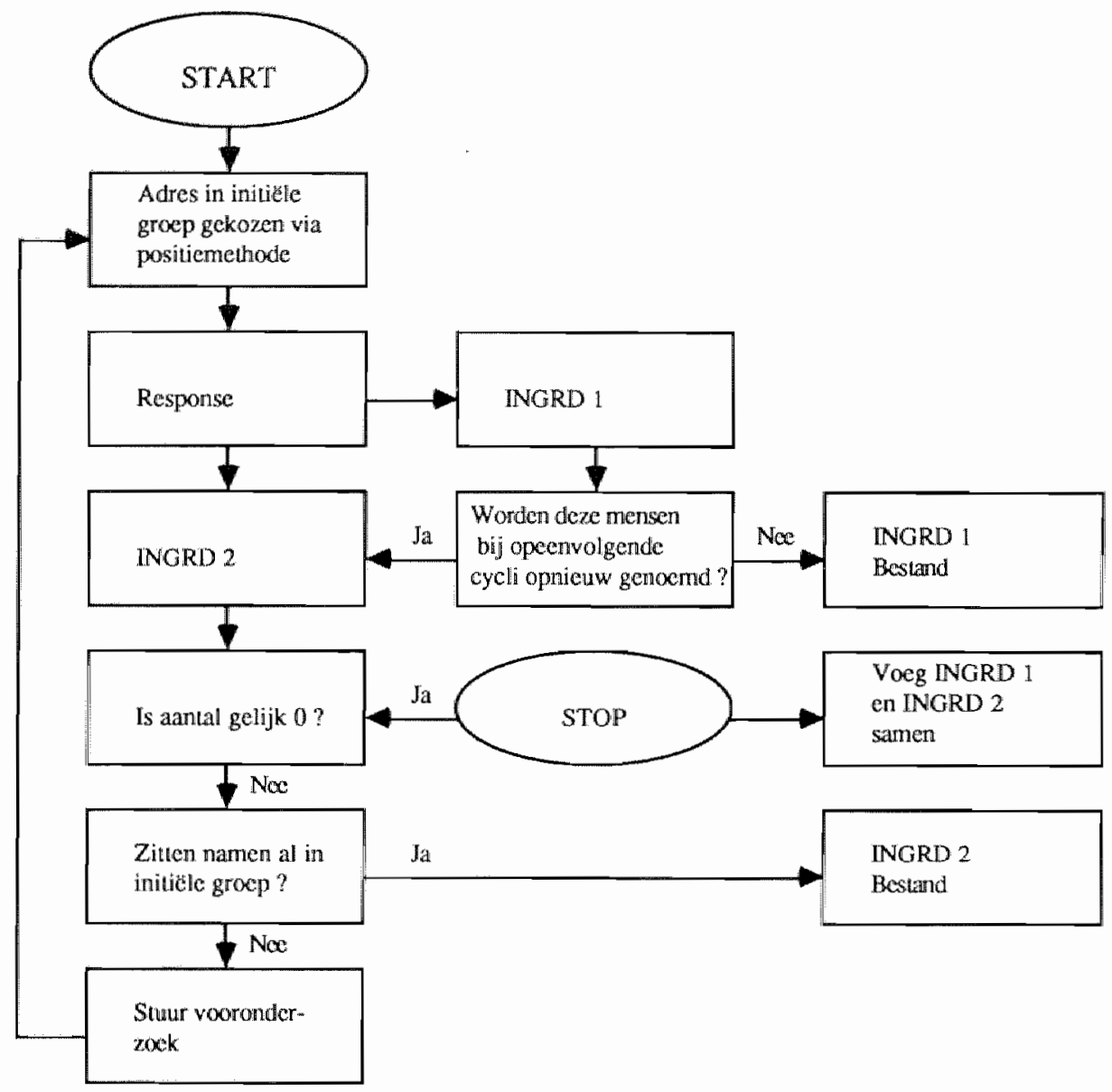

\subsection{HET SURVEY-ONDERZOEK}

\subsubsection{De survey-beschrijuing}

In het kader van deze studie werd gekozen voor een survey, door middel van een postale enquête. De schriftelijke enquête is een relatief eenvoudige methode voor data-verzameling en de toepassing ervan in het kader van dit onder- 
zoek is bruikbaar gebleken, temeer daar voor de onderbouwing van de uitspraken en de toegepaste statistische analyses een ruime steekproef vereist was. Ook de uitkomsten van het reputatie-onderzoek leidde tot een steekproef van betrekkelijk forse omvang. De wijze van formulering van de kernpunten van het onderzoek maakte een schriftelijk survey goed uitwoerbaar.

De vragenlijst is gezonden aan een afgebakende steekproef van mensen die qualitate qua - op grond van hun positie - betrokken zijn bij de aansluitingsproblematiek van het $\mathrm{HBO}$ en de beroepspraktijk, danwel op grond van de aan hen toegekende reputatie werden benaderd.

- Met de enquête werd een aanbiedingsbrief verzonden, waarin de nodige toelichting op de bedoelingen wan het onderzoek werd verschaft. De brief waarborgde de discretie en anonimiteit bij verwerking en rapportage. De omvang van de enquête was 123 items (met en zonder voorgecodeerde antwoorden).

- De respons op de enquête was redelijk. In totaal werd tweemaal een rappel verzonden. De volgende tabel geeft een overzicht van het effect daarvan.

Tabel 11: Steekproefgrootte en response na rappetering

\begin{tabular}{lccccc}
\hline Sector & $\begin{array}{l}\text { benaderde } \\
\text { steekproef }\end{array}$ & $\begin{array}{l}\text { directe } \\
\text { response }\end{array}$ & $\begin{array}{l}\text { response } \\
\text { 1e rappel }\end{array}$ & $\begin{array}{l}\text { response } \\
\text { 2e rappel }\end{array}$ & totaal \\
\hline Arbeid & 313 & 136 & 49 & 58 & $243(78 \%)$ \\
Onderwijs & 126 & 45 & 9 & 21 & $75 \%(60 \%)$ \\
Intermediair & 54 & 24 & 8 & 9 & $86 \%(76 \%)$ \\
\hline Totaal & 493 & 205 & 66 & 88 & $359(73 \%)^{*}$ \\
\hline
\end{tabular}

\section{Toelichting:}

- In totaal zijn 362 enquêtes ontvangen; drie konden niet gerubriceerd worden door ontbrekende namen en sectorgegevens. Rappelering leidde ertoe, dat in de sector arbeid alsnog 107 vragenlijsten werden ingezonden. Voor de sectoren onderwijs en intermediair bedroeg dit aantal respectievelijk 30 en 17. In totaal werden 154 vragenlijsten alsnog ontvangen. Het uiteindelijke responsepercentage is 73 .

De respons uit de sector onderwijs was - ondanks twee rappels én de betrokkenheid bij het thema - het laagste van de drie sectoren.

Over het geheel genomen is de respons behoorlijk. Daarbij kan worden aangetekend dat de respondenten in veel gevallen (op grond van het vooronderzoek) op de hoogte waren van het onderzoek en - bij het vooronderzoek - 
medewerking hadden toegezegd. Bij de vragenlijst kon worden aangegeven of de respondenten prijs stelden op toezending van een samenvatting van de voornaamste resultaten. Meer dan $95 \%$ gaf te kennen in toezending geïnteresseerd te zijn.

\subsection{DE INFORMANTENGROEP}

\subsubsection{Representativiteit}

Kan de respondentengroep als een representatieve afspiegeling worden beschouwd van de populatie "experts inzake aansluiting $\mathrm{HBO}$ en beroepspraktijk in Limburg"? Omdat geen exact overzicht van de populatieparameters beschikbaar was is een sluitend antwoord onmogelijk.

Ten aanzien van de generalisatie geldt dat de uitspraken worden beperkt tot de groep informanten die middels de reputatie of op grond van hun positie in het steekproefkader is opgenomen.

De kenmerken waarvan de verdeling in de steekproef (het aantal uitgezette enquêtes) vooraf bekend was betroffen de spreiding over de drie sectoren arbeid, onderwijs en intermediaire organisaties, de verdeling van de aard van de arbeidsorganisaties en de verdeling van de ingraad. In tabel 12 is de steekproef qua percentuele verdeling vergeleken met de respons.

Daaruit blijkt, dat de respons een redelijke afspiegeling is van de uitgezette steekproef. De antwoordbereidheid van mensen uit de sector arbeid is hoger dan die van mensen uit de sector onderwijs. Toch ontlopen de verdelingen in de steekproef en de respons elkaar niet veel; in de respons is de proportie mensen uit de sector arbeid hoger dan in de steekproef. Het omgekeerde beeld geldt voor de mensen uit de onderwijssector, mensen uit de intermediaire zijn in beide verdelingen in gelijke proporties vertegenwoordigd.

Tabel 12: Vergelijking van percentuele verdeling van enquetes en respons naar sector

\begin{tabular}{|c|c|c|c|c|c|c|c|c|}
\hline & $\geq 2^{u}$ & $\begin{array}{l}\text { gezet in } \\
\text { in voor- } \\
\text { onder- } \\
\text { zock }\end{array}$ & $\begin{array}{l}\text { naar sec } \\
\text { niet in } \\
\text { vooron- } \\
\text { derzoek }\end{array}$ & totaal & $22^{r}$ & $\begin{array}{l}\text { pons in } \\
\text { in voor- } \\
\text { onder- } \\
\text { zoek }\end{array}$ & $\begin{array}{l}\text { maar sec } \\
\text { miet in } \\
\text { vooron- } \\
\text { derzoek }\end{array}$ & totaal \\
\hline Arbeid & 43 & 75 & 79 & 63 & 52 & 76 & 78 & 70 \\
\hline Onderwijs & 48 & 16 & 6 & 26 & 38 & 14 & 9 & 19 \\
\hline \multirow[t]{2}{*}{ Intermediair } & 9 & 9 & 15 & 11 & 10 & 10 & 13 & 11 \\
\hline & 100 & 100 & 100 & 100 & 100 & 100 & 100 & 100 \\
\hline
\end{tabular}


Samenvattend kunnen wij stellen dat er geen grond is on systematische nonresponse te veronderstellen. De sneeuwbalmethode lijkt adequaat om lokale leiders (met een gedefinieerde reputatie) op het terrein van het onderhavige onderzoek op te sporen. Van de steekproef van 493 personen - opgebouwd via de reputatiemethode en via de positionele methode - werd een response ontvangen van 362 enquêtes, zijnde $73 \%$.

Gelet op de omvang, de a-select gekozen startpopulatie en de gebruikte combinatie van de twee methodes, mag worden verwacht dat de omvang van de steekproef nagenoeg gelijk is aan de groep lokale experts (de populatie) en dat het opgespoorde steekproefkader "lokale leiders" alle "lokale leiders" omvat. In totaal hadden 191 personen uit de steekproef $(39 \%)$ een ingraad $\geq$ 2 en 302 personen $(61 \%)$ een ingraad 1 of 0.

\subsubsection{Hoofdkarakteristieken van de respondenten in het kort}

De verdeling over sectoren, leeftijdsklasse en niveau van de hoogst genoten opleiding van de 362 informanten was als volgt:

Tabel 13: Leefïjd en niveau van de hoogst genoten opleiding wan de informanten gespecificeerd naar sector

\begin{tabular}{lccccccc}
\hline sector & aantal & $\begin{array}{c}\text { gemiddelde } \\
\text { leeftijd }\end{array}$ & MBO & HBO & WO & Overig & Totaal \\
\hline Arbeid & 248 & 42 & 4 & 43 & 44 & 9 & $100 \%$ \\
Onderwijs & 70 & 47 & & 27 & 66 & 7 & $100 \%$ \\
Intermediair & 44 & 42 & 3 & 70 & 18 & 9 & $100 \%$ \\
\hline Totaal & 362 & 43 & 3 & 43 & 45 & 9 & $100 \%$ \\
\hline
\end{tabular}

\section{Toelichting:}

De informanten uit het onderwijs beschikken in doorsnee over een hoger opleidingsniveau dan degenen die uit de arbeidssector en de kringen van intermediaire organisaties aan het onderzoek deelnamen.

De informanten hebben een nogal uiteenlopende werkervaring. De volgende tabel geeft inzicht in de duur van de werkzaamheid in de sector waarin men thans werkzaam is en de totale omvang van arbeidservaring waarover men beschikte. 


\begin{tabular}{|c|c|c|c|c|}
\hline \multirow[t]{2}{*}{ dewr: } & \multirow{2}{*}{\multicolumn{2}{|c|}{$\begin{array}{c}\text { thans werkzaam in sector } \\
\text { absolut }\end{array}$}} & \multicolumn{2}{|c|}{ totale arbeidsverleden } \\
\hline & & & absoluut & $\%$ \\
\hline - 1 jaar & 13 & 4 & - & . \\
\hline 2. 5 jaar & 49 & 14 & 41 & 11 \\
\hline 6- 10 jaar & 73 & 20 & 61 & 16 \\
\hline $11-20$ jaar & 144 & 40 & 126 & 35 \\
\hline 21 jaar en meer & 80 & 22 & 133 & 38 \\
\hline Onbekend & 3 & 1 & 1 & - \\
\hline Totaal & 362 & $100 \%$ & 362 & $100 \%$ \\
\hline
\end{tabular}

Uit de bovenstaande tabel blijkt, dat totaal $1 / 3$ van de respondenten minder dan 10 jaar, $1 / 3$ tussen 10 en 20 jaar en $1 / 3$ over meer dan 20 jaar concrete werkervaring beschikt.

\subsubsection{Betrokkenheid als kenmerk van de informanten}

De aspecten "invloed op" en "betrokkenheid bij" beleidsontwikkeling werden cruciaal geacht. In deze paragraaf gaan wij nader in op de vraag in hoeverre de respondenten zich betrokken achten bij de problematiek van het $\mathrm{HBO}$ en de beroepspraktijk.

Wij kennen aan mensen op bepaalde posities of met een bepaalde reputatie een zekere mate van betrokkenheid bij de problematiek toe. Alleen op grond van de positie kan men nog weinig zeggen over hun betrokkenheid bij de problematiek. Gaat het echter om de reputatie die iemand geniet inzake de aansluitingsproblemen van $\mathrm{HBO}$ en beroepspraktijk, dan is te verwachten dat een grotere reputatie ook een grotere betrokkenheid bij discussies en beleidsontwikkeling impliceert.

Reputatie is echter een kenmerk dat iemand wordt toegeschreven door anderen. Om vast te stellen of reputatie en betrokkenheid samengaan ligt het voor de hand de persoon in kwestie naar zijn betrokkenheid met de aansluitingsproblematiek te vragen.

Dit is gedaan door middel van drie vragen in het survey-onderzoek. De eerste had betrekking op de mate van beslissende invloed in beleidsontwikkeling en -uitvoering (BESLIS), de tweede richtte zich op de mate van betrokkenheid bij de discussies - zowel formeel als informeel - (DISC), terwijl de derde vraag handelde over de mate van betrokkenheid bij de beleidsontwikkeling (BELEID). 
De vragen zijn voorgelegd in de vorm van een 5-puntsschaal waarop men kon aangeven in hoeverre de uitspraak op hem/haar van toepassing was $(1=$ geheel niet van toepassing; $5=$ zeer van toepassing).

Voor het objectiveren van de reputatie is gebruik gemaakt van een ingraadindex die voor de gehele steekproef is opgesteld. Deze ingraad-index omvat de ingraad van het vooronderzoek en de ingraad die een respondent krijgt doordat hij/zij in de survey-enquête opnieuw wordt genoemd. Reden hiervoor is dat de uiteindelijke ingraad iemands reputatie het beste benadert: hoe vaker iemand wordt genoemd, des te meer reputatie hij geniet. Bovendien is op deze manier een controle op het vooronderzoek mogelijk. Als de ingraadindex sterk afwijkt van de ingraad uit het vooronderzoek dan heeft het vooronderzoek kennelijk niet het gehele reputatienetwerk blootgelegd.

Zoals uit tabel 15 blijkt, wijkt de uiteindelijk gevonden ingraadverdeling nauwelijks af van de ingraadverdeling uit het vooronderzoek. Dit sterkt ons in de gedachte dat het vooronderzoek inderdaad het beoogde bestand aan personen heeft opgespoord.

Tabel 15: Vergelijking van de ingraad wit vooronderzaek (INGRD) en de witeindelijk berekende ingraad (ID)

\begin{tabular}{lcc}
\hline genoemd: & INGRD & ID \\
\hline niet & $161(44 \%)$ & $155(43 \%)$ \\
1 maal & $102(28 \%)$ & $96(27 \%)$ \\
2 maal of meer & $99(28 \%)$ & $111(30 \%)$ \\
\hline Total & $362(100 \%)$ & $362(100 \%)$ \\
\hline
\end{tabular}

Voorts zijn de gemiddelden, gespecificeerd naar de categorieën van positie en reputatie, berekend voor de drie genoemde betrokkenheidsvariabelen. De hoogte van de categorie-gemiddelden geeft aan in welke mate men zich betrokken acht. Dit is samengevat in tabel 16.

De posities van de informanten leveren enige verschillen in gemiddelden op. Mensen uit onderwijs kenmen zich, ten aanzien van alle drie de vragen, een hogere betrokkenheid toe, terwijl respondenten uit de arbeids- en intermediaire sector zich minder betrokken voelen bij de problematiek. Wat opvalt is dat alleen informanten uit de sector onderwijs op de vraag naar betrokkenheid bij discussies en beleid relatief hoog scoren. Voor de steekproef als geheel geldt echter, dat men zich niet of nauwelijks betrokken voelt bij de problematiek. 
Tabel 16: Calgorie-gemiddelden voor "beslisserde inwloed" (BESLIS), "betrokken bij discussie" (DISC) en "betrakken bij beleid" (BELEID) gespecificeerd naar positie (V7) en ingraad" (ID) op basis wan Likertscores

\begin{tabular}{|c|c|c|c|}
\hline & $\begin{array}{l}\text { positie informant: } \\
\text { BESLIS }\end{array}$ & DISC & BELEID \\
\hline arbeid & $204(242)$ & $251(243)$ & $166(241)$ \\
\hline ondie rwijis & $290(70)$ & $396(70)$ & $328(72)$ \\
\hline intermediair & $203(40)$ & $248(40)$ & $154(41)$ \\
\hline Totaal & $221(352)$ & $279(353)$ & $197(353)$ \\
\hline \multirow[t]{2}{*}{ eta: } & $.31 p<.05$ & $.42 \quad \mathrm{p}<.05$ & $.52 p<.05$ \\
\hline & $\begin{array}{l}\text { ingraad informant: } \\
\text { BESLIS }\end{array}$ & DISC & BELEID \\
\hline $0 \mathrm{maal}$ & $200(154)$ & $232(155)$ & $156(154)$ \\
\hline $1 \mathrm{maal}$ & $220(95)$ & $286(94)$ & $194(94)$ \\
\hline $2 \mathrm{en}$ meer & $250(106)$ & $341(107)$ & $256(108)$ \\
\hline Totaal & $220(355)$ & $279(356)$ & $196(356)$ \\
\hline eta: & $.19 p<.05$ & $.34 \quad p<.05$ & $.33 p<.05$ \\
\hline
\end{tabular}

\section{* Toelichting op de tabel}

De bovengenoemde scores zijn gepresenteerd op een additieve schaal. Additieve schalen gaan uit van de ruwe scores op variabelen (in ons voorbeeld beslis, disc en beleid) waarbij alle scores worden opgeteld en gedeeld door het aantal respondenten. De aldus berekende gemiddelden zijn - voor de duidelijkheid - vermenigvuldigd met 100 . Dergelijke schalen staan bekend onder de naam Likertschalen.

De ingraad laat een duidelijke conclusie toe: naarmate men meer reputatie geniet als terzake kundige, kent men zichzelf ook meer betrokkenheid bij de materie toe. Op zich is dat niet verwonderlijk, reputatie geniet men juist doordat men zich op een of andere wijze actief met de problematiek van de verhouding wan het $\mathrm{HBO}$ en de beroepspraktijk, zoals in de afname van de onderzoeken werd gepresenteerd, bezighoudt.

Uit de gepresenteerde overzichten blijkt verder dat het item "betrokkenheid bij discussies" (DISC) het hoogste gemiddelde oplevert, zowel voor de positiecategorieën als de ingraadcategorieën. Beide andere vragen (naar beslissende invloed en betrokkenheid bij beleidsontwikkeling) laten duidelijk lagere scores zien. Een mogelijke verklaring voor de lage scores op de vraag naar beslissende invloed is dat mensen over het algemeen niet snel van zichzelf zullen 
zeggen beslissende invloed te bezitten. Dit is een bekend thema in de kritieken op de reputatiemethode (cf. Felling, 1974a; Wassink en Braam, 1984).

De lage scores op de vraag naar betrokkenheid bij beleidsontwikkeling wijzen erop, dat men daar - als er al sprake is van mogelijkheden tot deelname over het algemeen niet aan deelneemt.

Een uitzondering hierop vormen de respondenten uit de onderwijssector; zij achten zich meer betrokken bij beleidsontwikkeling dan mensen uit de arbeidssector en de intermediaire sector.

Zien wij af van graduele verschillen en dichotomiseren wij de scores op de drie vragen in een categorie "niet of nauwelijks betrokken" (scores 1, 2, 3) en een categorie "wel betrokken" (scores 4, 5) en zetten dit vervolgens af tegen positie en reputatie, dan blijkt dat alleen "beslissende invloed" niet significant samenhangt met de ingraadverdeling (zie bijlage III voor overzichten van respectievelijk positie en reputatie tegen BESLIS, DISC, BELEID). Deze samenhang tussen reputatie en politieke betrokkenheid ondersteunt de verwachting dat wij met relevante actores op het terrein van de aansluiting van $\mathrm{HBO}$ en arbeid te maken hebben.

Samenvattend: Door het gecombineerd gebruik van reputatie- en positiemethode kon een respondentengroep worden samengesteld. De positie van - potentiele informanten vormde het vertrekpunt voor het reputatie-onderzoek. Het middels deze methode gegenereerde namenbestand werd - met positie als selectiecriterium - aangevuld tot de steekproef. Het survey leverde in enkele gevallen weer bruikbare informatie op met betrekking tot het "issue" reputatie. Dit leidde tot nazending van een enquete. De respondentengroep kan worden beschouwd als een representatieve afspiegeling van de uitgezette steekproef. De invloed op beleidsontwikkeling en -uitvoering, betrokkenheid bij discussies en betrokkenheid bij beleidsontwikkeling, is vastgesteld middels drie vragen. De positie van de informanten en de ingraad (als index voor reputatie) leverden op deze punten belangrijke verschillen op. 


\section{Het onderzoek naar dimensies}

\subsection{INLEIDING}

In dit hoofdstuk wordt ingegaan op de resultaten van het onderzoek naar de dimensies. De vraag is welke de achterliggende factoren zijn binnen het totaal van visies en verwachtingen inzake de gepresenteerde kernthema's. Het dimensionaliseringsonderzoek wordt beschreven in par. 7.2. Aan de structuur van de factoren en de subdimensies daarin (de concepten) wordt apart aandacht besteed. Het hoofdstuk vervolgt met een resumé t.a.v. de aangetroffen dimensionaliteit (par, 7.3) en wordt besloten met een samenvattende beschouwing.

\subsection{DIMENSIONALISERINGSONDERZOEK}

\subsubsection{Het conceptuele systeem van de informanten}

De beschrijving van het opsporen van dimensionaliteit in de reacties van de 362 informanten staat in deze paragraaf centraal. Het materiaal daartoe bestond uit de scores op de variabelen met betrekking tot de hoofddomeinen kwaliteit, interactie en structuur.

De centrale vraag was of de drie hoofddomeinen herkenbaar bleven in de antwoorden. Met andere woorden, welke latente variabelen te ontdekken zijn c.q. langs welke hoofdlijnen de beoordeling van de verhouding van HBO en beroepspraktijk in de toekomst plaatsvindt.

Dit deel van de analyse geeft een inzicht in de vraag hoe de groep van experts in totaliteit denkt en gaat na of relevante subgroepen verschillend van elkaar denken. We gaan in deze paragraaf nog niet in op verschillen in wenselijkheid (toegekend aan specifieke ontwikkelingen) die kunnen bestaan tussen subgroepen van experts. We zijn primair op zoek naar de homogeniteit van een conceptueel systeem bij de geraadpleegde experts en het antwoord op de vraag hoe dat systeem eruit ziet. 


\subsubsection{Principale componentenanalyselde structuur van de factoren en de interpretatie ervan}

Ten einde de dimensies inzake de visies met betrekking tot de hoofdthema's te onderzoeken is een principale componentenanalyse uitgevoerd op de datamatrix van alle 362 informanten. De opgespoorde factoren vatten wij op als relevante gezichtspunten van experts bij de beoordeling van het probleem. De tabellen op de volgende pagina's geven een overzicht van de factoren. Deze factorstructuur is gebaseerd op de analyse van de data van de gehele groep informanten. De interpretatie van de gevonden structuur is weergegeven. Ter toelichting op de tabellen 17 en volgende dient dat de antwoorden op 87 items deel uitmaakten van het bestand van data, zoals dat werd geanalyseerd. Onderstaand volgt een overzicht van de zes factoren, het aantal hoog ladende items, de factorladingen alsmede de betrouwbaarheidsmaat alpha en de eigen-waarden die werden berekend.

\section{Tabel 17: Factor I: SOCLAAL-NORMATIEVE KWALTTEITSASPECTEN}

In de eerste kolom van de tabel zijn de itemnummers vermeld van uitspraken met een lading $>.40$ (kolom 2) op factor no. I "sociaal-normatieve kwa liteitsaspecten". In de derde kolom is de strekking van het item kort aangegeven. De factorlading geeft de correlatie aan tussen het betreffende item en de geconstrueerde factor.

Item: Lading op Item inhoud:

no. factor I:

\begin{tabular}{lll}
\hline 60 & .78 & het plannen van eigen werk \\
59 & .77 & het organiseren van eigen werk \\
53 & .65 & een actiewe werkhouding \\
63 & .61 & het samenwerken met collegae \\
83 & .59 & rapportagetechnieken/vardigheden \\
58 & .59 & het ontwikkelen van initiatieven \\
73 & .58 & het omgaan met veranderingen in de beroepspraktijk \\
54 & .58 & een klantgerichte instelling \\
62 & .57 & het ontwikkelen van ideeën \\
67 & .56 & het samenwerken met instellingen \\
84 & .55 & mondelinge communicatieve vaardigheid \\
61 & .54 & het nemen van beslissingen \\
68 & .54 & het effectief extern presenteren \\
85 & .54 & schriftelijke communicatieve vaardigheid \\
88 & .50 & persoonlijke flexibiliteit \\
66 & .49 & samenwerken met vrijwilligers \\
87 & .48 & het inleven bij communicatie \\
72 & .47 & informatie verschaffen \\
75 & .47 & het doen van keuzes \\
76 & .47 & het omgan met veranderingen in de samenleving \\
74 & .45 & het begeleiden van mensen bij verandering \\
65 & .45 & het samenwerken met superieuren \\
78 & .43 & het beheersen van technieken woor dataregistratie \\
\hline
\end{tabular}

(alpha 91 /eigenwaarde $11.97 / 23$ items laden hoog op deze factor) 


\section{Interpretatie:}

De variabelen welke op deze factor hoog laden hebben alle betrekking op het aspect specifieke eisen die aan HBO-ers kunnen worden gesteld. Het zijn elementen van de kwaliteitsvraag, (een van de kernvragen) welke eisen aan de output van toekomstig HBO kunnen/moeten worden gesteld.

De factor levert een patroon van eisen/verwachtingen, dat tot de volgende hoofdlijn is te herleiden:

"kwaliteit, uitgedrukt in termen van "sociaal-normatieve vaardigheden", toegespitst op de aspecten samenwerken met anderen, leidinggeven aan anderen, zelfstandigheid en persoonlijke flexibiliteit en uitdrukkingsvaardigheid in de beroepspraktijk".

\section{Tabel 18: Factor II: DE INTERACTIE VAN HBO EN BEROEPSPRAKTIIK}

In de eerste kolom van de tabel zijn de itemnummers vermeld van uitspraken met een lading $>.40$ (kolom 2) op factor no. II Interactie $\mathrm{HBO}$ en beroepspraktijk. In de derde kolom is de strekking van het item kort aangegeven.

Item: Lading op Item inhoud:

no. factor II:

\begin{tabular}{lrl}
\hline 26 & -.64 & het HBO moet worden bepald door eisen arbeid \\
19 & .61 & het HBO moet niet worden bepaald door eisen arbeid \\
16 & -.58 & meer aandacht voor het woorbereiden van leerlingen op de beroepspraktijk \\
20 & .57 & de sfeer in HBO en beroepspraktijk moet verschillend zijn \\
21 & .55 & het HBO moet een autonoom institut zijn \\
13 & -.53 & het HBO moet afhankelijk zijn t.o. werkveld \\
15 & -.46 & het HBO moet bereid zijn tot open dialoog met het werkveld \\
14 & .45 & het HBO moet zelf eisen bepalen voor zijn abituriënten \\
23 &. .42 & het HBO moet ontwikkelingen in arbeid attent volgen
\end{tabular}

(alpha $73 /$ eigenwarde $3.77 / 9$ items opgenomen)

\section{Interpretatie:}

Alle variabelen die hoog laden op deze factor hebben betrekking op de relatie van onderwijspraktijk en beroepspraktijk, meer specifiek waar het gaat om de vraag hoe de verhouding moet zijn, hoe ver de afhankelijkheid van onderwijs tot de beroepspraktijk moet gaan. De items bestrijken de dimensie van "een al dan niet t.o.v. de beroepspraktijk afhankelijk gestelde "onderwijs-praktijk", een situatie waarin de eisen uit de beroepspraktijk al dan niet het uitgangspunt en kader vormen voor de inrichting van de onderwijspraktijk". 
In de eerste kolom zijn de itenunummers vermeld van uitspraken met een lading $>40$ (kolom 2$)$ op factor III "Flexibiliteit van het HBO t.o.v. de beroepspraktijk". In de derde kolom is kort de strekking wan thet item aangegeven. De factorlading geeft de correlatic aan ussen het betreffende item en de geconstrueerde factor.

\section{Item: Lading op Item inhoud:}

no. factor III:

\begin{tabular}{lll}
37 & .65 & de invoring van deelcertificaten voor $\mathrm{HBO}$ \\
38 & .61 & de inwoering van leerlingstelsel op HBO-niveau \\
47 & 59 & het HBO moet meer geintegreerd worden in de samenleving \\
31 & .56 & het HBO moet meer in de beroepspraktijk gegeven worden \\
25 & .56 & meer ruimte voor stages moet worden ingebouwd \\
32 & .55 & meer decentratisatie/individualisatie in HBO \\
46 & 55 & het HBO moet niet in afgeronde pakketten worden aangeboden \\
39 & .47 & de studenten moet meer invioed op het HBO gegeven worden \\
33 & .46 & het HBO moet in weine eenheden worden aangeboden \\
35 & .43 & de betekenis wan het HBO woor de samenleving moet meer gerelativeerd worden \\
\hline
\end{tabular}

(alpha $.77 /$ eigenwaarde $3.03 / 10$ items laden hoog op deze factor)

\section{Interpretatie:}

De hoog op deze factor ladende variabelen hebben alle de vorm waarin het onderwijsleerproces gestalte krijgt tot onderwerp. Meer bepaald betreffen zij de mate waarin sprake moet zijn van flexibel en soepel veranderbaar, extern beinvloedbaar HBO dat op individuele behoeften is toe te snijden en in kleine zelfstandige en overzienbare eenheden wordt gegeven, dat geen vaste eindstadia maar individueel te bepalen kwalificatieniveaus kent.

\section{Tabei 20. Factor N: ALGEMENE VERSUS SPECIFIEKE HBO.OPLEIDING}

In de eerste kolom zijn de itemnummers vermeld van uitspraken met een $\|$ ading $>.40$ (kolom 2) op factor no. IV "Algemene versus specifieke HBO opleiding". In de derde kolom is de strekking wan het item kort aangegeven. De factorlading geeft de correlatie aan tussen her betreffende iten en de geconstrueerde factor.

Item: Lading op Item inhoud:

mo. factor IV:

\begin{tabular}{lrl}
\hline 91 & .74 & algemeen opleidend HBO als wenselijkheid \\
92 & -.66 & specifiek opleidend HBO als wenselijkheid \\
106 & .65 & het HBO moet vooral algemene kwalificaties bieden \\
42 & -.65 & het HBO moet voorall specifiek opgeleide studenten vormen \\
45 & .59 & het HBO mot brede voorbereiding op het leven bieden \\
24 & .52 & het HBO moet meer algemeen vormende vakken biedem \\
\hline
\end{tabular}

(alpha .73/eigenwaarde $2.58 / 6$ items laden hoog op deze factor) 
Alle variabelen hebben betrekking op de mate waarin het $\mathrm{HBO}$ specifiek (eenzijdig) op een beroep toegesneden moet opleiden of a-specifiek - (meerzijdig) op algemene kwalificatie-aspecten toegesneden moet opleiden:

De items bestrijken, in combinatie met elkaar, de dimensie: breed georienteerde en voorbereide studenten; een complex van wenselijkheden met betrekking tot abiturienten die flexibel qua uitrusting, meerzijdig inzetbaar, duidelijk algemeen opgeleid zijn.

\section{Tabel 21: Factor V: TECHNISCH-INSTRUMENTELE KWALIFICATIES}

In de eerste kolom zijn de itemnummers vermeld van uitspraken met een lading $>.40$ (kolom 2) op factor no. V: "Technisch Instrumentele Kwalificaties". In de derde kolom is de strekking van het item aangegeven. De factorlading geeft de correlatie aan tussen het betreffende item en de geconstrueerde factor.

\section{Item: Lading op Item inhoud:}

no. factor $\mathrm{V}$ :

\begin{tabular}{lll}
\hline 48 & -.77 & managementtechnieken \\
80 & -.75 & marketingtechnieken \\
49 & -.66 & organisatie-ontwikkeling \\
82 & -.62 & budgetbewaking \\
81 & -.62 & fondswerving \\
50 & -.55 & organisatieverandering \\
52 & -.54 & beleidsontwikkeling \\
64 & -.48 & leidinggeven \\
70 & -.48 & onderhandelen \\
79 & -.42 & onderzoekstechnieken
\end{tabular}

(alpha 83 /eigenwaarde $2.41 / 10$ items laden hoog op deze factor)

\section{Interpretatie:}

De variabelen betreffen alle vaardigheden, toegespitst op beleidsontwikkeling en leidinggevende capaciteit voor zover deze op het functioneren binnen de eigen organisatie zijn gericht.

Zowel factor I als factor V betreffen de dimensie "kwaliteitsaspecten". De aldus gevonden beide hoofddimensies van "kwaliteit" (FACTOR I en FACTOR V) wijzen in de richting van het - onder andere - door van Wieringen 1976, en van Kemenade, 1981 gemaakte onderscheid tussen sociaal-normatieve kwalificaties en technisch-instrumentele kwalificaties. Hoewel de eerste dimensie kwalificatie termen omvat die wijzen in de richting van de context waarbinnen de arbeidsprestatie moet worden geleverd (de sociaal-normatieve kwalificaties), zijn er ook termen die wijzen op de toerusting van kwalificaties in een functionele relatie met de te leveren arbeidsprestatie. 
Voor de dimensie beschreven bij factor $\mathrm{V}$ gevonden geldt het omgekeerde: de meeste termen wijzen in de richting van technisch-instrumentele kwalificaties, en wel naar wat van Hoof en Dronkers de "trainability" hebben genoemd, de "... meer algemeen, minder direct aan een concrete functie gebonden eigenschappen" (1980: pag. 54). Omwille van de duidelijkheid noemen wij de in factor I gevonden dimensie de sociaal-normatieve dimensie en de in factor $\mathrm{V}$ geïnterpreteerde dimensie de technisch-instrumentele. Wij verwijzen voor een nadere interpretatie naar paragraaf 7.2.3.

\section{Tabel 22: Factor WI: REGELGEVING/OVERLEG}

In de eerste kolom zijn de itemnummers vermeld van uitspraken met een lading $>.40$ (kolom 2) op factor no. VI: Regelgeving/overleg. In de derde kolom is de strekking van het item aangegeven. De factorlading geeft de correlatie aan tussen het betreffende item en de geconstrueerde factor.

\begin{tabular}{lcl}
\hline $\begin{array}{l}\text { Item: } \\
\text { no. }\end{array}$ & $\begin{array}{l}\text { Lading op } \\
\text { factor VI: }\end{array}$ & Item inhoud: \\
\hline 36 & .82 & $\begin{array}{l}\text { Nationale regelgeving primair t.b.v. relatie HBO-arbeid } \\
\text { Lokalal overleg primair t.b.v. relatie HBO-arbeid }\end{array}$ \\
\hline 41 & -.81 & \\
\hline
\end{tabular}

(alpha .77/eigenwaarde 2.01/2 items opgenomen)

Interpretatie:

Deze dimensie omvat slechts twee uitspraken die inhoudelijk elkaars tegengestelde zijn en betrekking hebben op de vraag waar het werken aan de relatie $\mathrm{HBO}$-arbeid het meest mee gediend is, met nationale regelgeving dan wel lokaal overleg.

Wij kunnen - gegeven de gevonden factorstructuur - concluderen tot het bestaan van een aantal "complexen van wenselijkheden" die zich laten duiden als zes clusters of hoofdlijnen, waarlangs - binnen de voorgelegde itempool de toekomst van de relatie van HBO en beroepspraktijk wordt gepercipieerd. Dit resultaat correspondeert inhoudelijk in redelijke mate met de veronderstelde denkkaders.

De keuze tot de "zes-factoroplossing" is de meest verstandige gebleken; in deze keuze is het optimum gerealiseerd van methodisch-technische strengheid en een redelijk genuanceerde, inhoudelijke ontleding van het beschikbare materiaal. In totaal blijken 60 van de 87 items te passen in een interpreteerbare zes-factoriële oplossing. 
De factoren van het gerealiseerde model waarmee verder gewerkt zal worden zijn niet onafhankelijk van elkaar, ze hangen op onderdelen samen; waar die samenhang relevant is wordt er nader op ingegaan. Wij zullen thans allereerst de dimensies die uit de zes factoroplossing resulteerde nader beschrijven door deze per dimensie nader te detailleren.

\subsubsection{Subdimensies binnen de factoren; de concepten}

De variabelen per factor aanwezig, werden vervolgens als aparte variabelensets geanalyseerd. Dit is gedaan om te zien of de gevonden hoofddimensies nog op te splitsen waren in een of meer subdimensies. Dat bleek inderdaad het geval voor vijf van de zes geanalyseerde factoren. Op de volgende pagina's staat de aldus gevonden - meer microscopische - structuur afgebeeld. De labels die aan de subdimensies (aangeduid met de term concept $=$ CONC) zijn gegeven zijn gebaseerd op de inhoud en de strekking van de variabelen. In totaal vonden wij 13 concepten, telkens opgevat als één element van één hoofddimensie.

Wij starten de rapportage met een overzicht van de aldus in factor I gevonden concepten. Ter toelichting op de navolgende overzichten dient het volgende:

In de eerste kolom zijn de nummers vermeld van de items die tezamen factor I vormden ( $62 \mathrm{t} / \mathrm{m} 76$, in dit voorbeeld). In de tweede kolom zijn de itemnummers herhaald in het geval bepaalde items - in combinatie met elkaar - een concept vormden. In het voorbeeld (van de concepten binnen factor I) waren dit de verzamelingen $62 \mathrm{t} / \mathrm{m} 87$ (CONCEPT 11), $85 \mathrm{t} / \mathrm{m} 78$ (CONCEPT 12) etc. De 7 resterende items $(53 \mathrm{t} / \mathrm{m} 76)$ werden niet in een van de vier aldus gevonden concepten opgenomen.

Tabel 23: Owerzich van concepten met betrekking tot sociaal-mormatieve kwalificaties (factor I)

\begin{tabular}{lll} 
& & Zelfstandigheid (CONC. 11) \\
62 & 62 & het ontwikkelen van ideeën \\
58 & 58 & het ontwikkelen van initiatieven \\
61 & 61 & het nemen van beslissingen \\
75 & 75 & het doen van keuzes \\
87 & 87 & het inleven bij communicatie \\
\hline \multicolumn{3}{l}{ Communicatieve vaardigheden (CONC. 12) } \\
85 & 85 & schriftelijke communicatieve waardigheden \\
84 & 84 & mondelinge communicatieve vaardigheden \\
83 & 83 & rapportagetechniek/vaandigheden \\
78 & 78 & het beheersen van technieken voor dataregistratie \\
\hline
\end{tabular}


Vervolg tabel 23: Overzicht van concepten met berrekkng tot socianlmomatieve kwalificaties (factor 1$)$

\begin{tabular}{|c|c|c|}
\hline & & Samenwerking (CONC. 13) \\
\hline 66 & 66 & de sannenwerking met vrijwilligers \\
\hline 67 & 67 & het samenwerken met instellingen \\
\hline 65 & 65 & het samenwerken met superieuren \\
\hline \multirow[t]{2}{*}{74} & 74 & het begeleiden van mensen bij verandering \\
\hline & & Organisatie en planming (CONC. 14) \\
\hline 59 & 59 & het organiseren wan eigen werk \\
\hline 60 & 60 & het plammen van eigen werk. \\
\hline 63 & 63 & het samemwerken met collega's \\
\hline 53. & & een actieve werkmouding \\
\hline 73. & & het omgaan met veranderingen in de beroepspraktij]k \\
\hline 54 & & een klantgerichte instelling \\
\hline 68 & & het effectief extern presenteren \\
\hline 72 & & het informatie verschaffen \\
\hline 88 & & persoonlijke flexibiliteit \\
\hline 76 & & het omgaan met veranderingen in de samenleving \\
\hline
\end{tabular}

In verband met de inhoudelijke samenhang tussen de beide factoren zullen wij de concepten behorend tot factor $I$ en $V$ in eén kader bespreken. Wij geven daartoe eerst het overzicht van de concepten in factor $\mathrm{V}$.

Tabel 24: Overzicht van concepten met betrekking tot technisch-instrumentele kwalificaties (factor b)

\begin{tabular}{|c|c|c|}
\hline & & Leidinggeven (CONC. 51) \\
\hline 49 & 49 & arganisatie-ontwikkeling \\
\hline 50 & 50 & organisatic-verandering \\
\hline$\$ 2$ & 52 & beleidsontwikkeling \\
\hline 48 & 48 & organisatie-technicken \\
\hline \multirow[t]{2}{*}{64} & 64 & leidinggeven \\
\hline & & Managementechmieken (CONC. 52) \\
\hline 81 & 81 & fondswerving \\
\hline 80 & 80 & marketingtechnieken \\
\hline 79 & 79 & onderzoekstechnieken \\
\hline 82 & 82 & budgetbewaking \\
\hline 70 & & ondlerhandelen \\
\hline
\end{tabular}


Zelfstandigheid wordt hoofdzakelijk gezien als het vermogen ideeën te ontwikkelen en initiatieven te ontplooien en lijkt een apart begrip te vormen in de beoordeling van het programma van wenselijkheden geldend voor de HBO-er (CONC. 11). De items met betrekking tot het organiseren en het plannen van het eigen werk vormen tezamen met het item "samenwerken met collegae" een apart concept (CONC. 14). Het samenwerken met collegae wordt op een andere manier gezien dan het samenwerken met vrijwilligers, instellingen en superieuren dat samen met begeleiding van individuen het begrip samenwerking omvat (CONC. 13). Wellicht verwijst samenwerken met vrijwilligers, instellingen en superieuren, alsmede het begeleiden van individuen eerder naar de formele taakstelling van de $\mathrm{HBO}$-er in een arbeidsorganisatie (het behoort expliciet tot zijn taak), terwijl het organiseren en plannen van eigen werk vooral gezien wordt in samenhang met collegiale samenwerking, dat eerder verwijst naar informele omgang.

Het begrip communicatieve vaardigheden (CONC. 12) spreekt voor zich: het gaat hier om de instrumentele kennis inzake communicatie. Het meer persoonsgebonden kenmerk van "het zich kunnen inleven in en het invoelen bij communicatie" wordt - door de respondenten - onder de noemer van zelfstandigheid gebracht. Op zichzelf is dit niet zo verwonderlijk: zelfstandigheid wordt kennelijk gezien als een persoonsgebonden eigenschap, waarmee echter niet gezegd wil zijn dat het $\mathrm{HBO}$ niets aan de ontwikkeling van zelfstandigheid zou kunnen doen. Het gaat er in dit geval om dat zelfstandigheid als een apart en wezenlijk kwaliteitsaspect van de toekomstige HBO-er in de beroepspraktijk wordt gezien. De andere kwaliteitsdimensie (FACTOR V) omvat twee concepten. Het eerste concept is "leidinggeven" genoemd. Het omvat uitspraken die duidelijk verwijzen naar de actieve inbreng die van de HBO-er wordt verwacht in de ontwikkeling en verandering in beleid en organisatie.

Het is wellicht deze eigenschap van de HBO-er die een zekere mate van instrumentele kennis veronderstelt, kennis die ook tot uitdrukking komt in de tweede concept "management-ondersteunende technieken". Immers, het niveau waarop HBO-ers doorgaans werkzaam zijn vereist een actieve inbreng in organisatie-ontwikkeling en begeleiding, die zonder enige kennis omtrent het werven van fondsen, marketing, budgettering en beleidsonderzoek weinig effectief zal zijn. De correlatie tussen scores op deze twee concepten wijst ook in die richting ( $r=.50$, zie blad 4 van bijlage IV). 


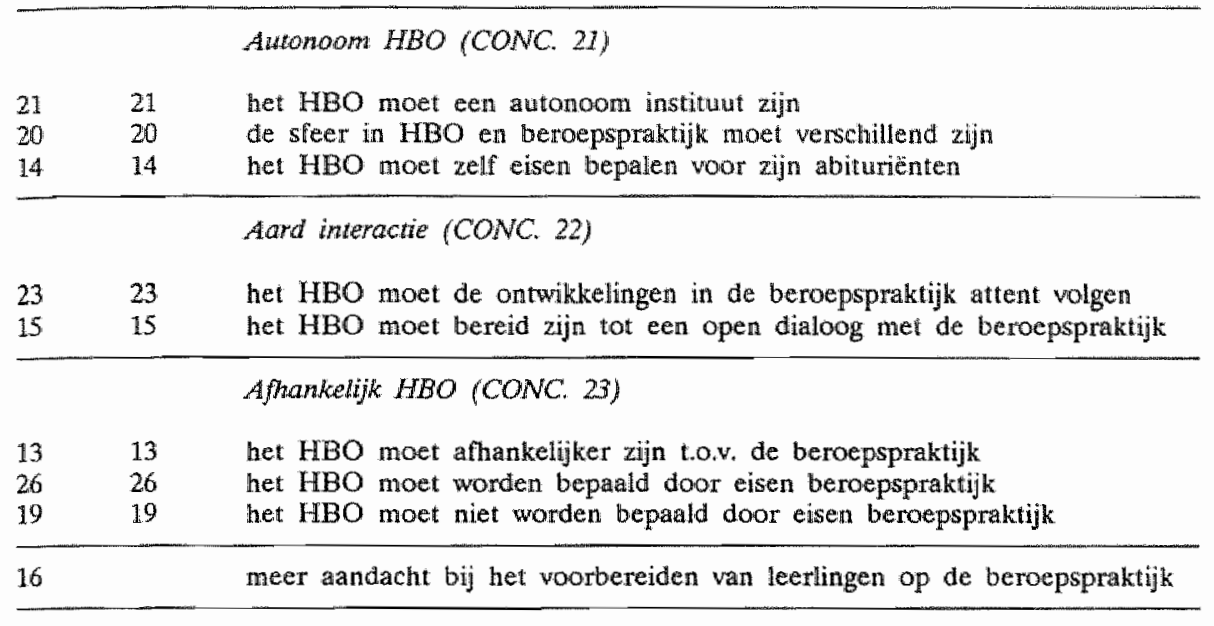

Interpretatie van de concepten binnen factor II:

Bij de beoordeling van de interactie tussen het $\mathrm{HBO}$ en de beroepspraktijk blijkt de autonomie van het HBO een belangrijk thema te zijn. Dit komt overeen met wat reeds in hoofdstuk 3, op grond van een inventarisatie van de discussiethema's, werd verondersteld.

Hier blijkt dat de geoperationaliseerde aspecten niet alle terug te vinden zijn in de concepten van deze dimensie (FACTOR II; zie bijlage I). Twee van de drie concepten binnen deze dimensie hangen duidelijk samen. Het eerste concept omvat uitspraken die het zelfstandige karakter van het $\mathrm{HBO}$ benadrukken (CONC. 21) terwijl het derde concept (CONC. 23) juist de afhankelijkheid van het $\mathrm{HBO}$ onderstreept. Die afhankelijkheid van het $\mathrm{HBO}$ heeft betrekking op de mate waarin het $\mathrm{HBO}$ zich moet richten op de eisen van de beroepspraktijk.

De samenhang komt tot uitdrukking in een negatieve correlatie $(r=-.44)$. Verwezen wordt naar blad 4 van bijlage IV.

Deze significante samenhang wijst er bovendien op dat de concepten niet sterk tegengesteld zijn. Het tweede concept (CONC. 22) heeft expliciet betrekking op de aard van de interactie, die wordt omschreven in termen van het attent volgen van ontwikkelingen op de arbeidsmarkt en het bereid zijn tot het aangaan van een open dialoog. De aard van de interactie wordt kennelijk los gezien van de vraag of het HBO nu een autonoom of afhankelijk instituut moet zijn. Er is geen relevante correlatie aangetroffen tussen de concepten 
aard van de interactie en de concepten met betrekking tot autonomie of afhankelijkheid.

Tabel 26: Overzicht van concepten met betrekking tot fledibiliteir van het HBO (factor III)

\begin{tabular}{|c|c|c|}
\hline & & Interne flexibiluteit (CONC. $3 I)$ \\
\hline 33 & 33 & het $\mathrm{HBO}$ moet in kleine eenheden worden aangeboden \\
\hline 39 & 39 & de studenten moet meer invloed geboden worden op het HBO \\
\hline 37 & 37 & de imoering wan deelcertificaten woor $\mathrm{HBO}$ \\
\hline 32 & 32 & meer decentralisatie/individualisatie in het $\mathrm{HBO}$ \\
\hline 46 & 46 & het HBO moet niet in afgeronde pakketten worden aangeboden \\
\hline \multirow[t]{2}{*}{35} & 35 & de betekenis van het HBO voor de samenleving moet meer worden gerelativeerd \\
\hline & & Exteme flexibiliteit (CONC. 32) \\
\hline 31 & 31 & het $\mathrm{HBO}$ moet meer in de beroepspraktijk gegeven worden \\
\hline 25 & 25 & meer ruimte voor stages moet worden ingebouwd \\
\hline 38 & 38 & de inwoering van het leerlingenstelsel op HBO-niveau \\
\hline 47 & & het $\mathrm{HBO}$ moet meer geïntegrcerd worden in de lokale samenleving \\
\hline
\end{tabular}

Interpretatie van de concepten binnen factor III:

Wanneer de structuur-dimensie (FACTOR III) op zich nader wordt beschouwd dan komen ook hier twee concepten (CONC. 31 en CONC. 32) te voorschijn. De toekomstige wenselijkheid van de $\mathrm{HBO}$-structuur wordt binnen beide primair gezien in termen van flexibiliteit. Het eerste concept omvat uitspraken die wijzen op de interne structuur van het HBO: de mate waarin het HBO flexibeler moet zijn in zijn lesprogramma's door in kleine eenheden les te geven, deelcertificaten te verstrekken en een geindividualiseerde aanpak te gebruiken. Opmerkelijk is dat in deze opvatting over de interne structuur de studenten minder invloed moet worden toegekend (dit item laadt negatief op het concept). Dat daarbij de betekenis van het $\mathrm{HBO}$ voor de samenleving moet worden gerelativeerd kan erop wijzen dat deze dimensie verwijst naar de mate waarin sprake is van een complex van wenselijkheden in de richting van een pragmatischer en zakelijker HBO.

Daarnaast is er een dimensie waarneembaar die wijst in de richting van HBO dat een grotere mate van externe flexibiliteit aan de dag gaat leggen.

Een actieve manifestatie in de beroepspraktijk, meer ruimte voor stages in de opleiding en de wenselijkheid het leerlingstelsel in het HBO op te nemen (CONC. 32) wijzen in die richting. Tussen de beide concepten bestaat een positieve samenhang ( $r=36$, zie blad 4 , bijlage IV). 
Tabel 27: Owerzicht van concepten met betrekking tot algemene versas specifieke HBO-opuleidugen (factor $M)$

\begin{tabular}{|c|c|c|}
\hline & & Breed opleidend HBO (CONC. 41) \\
\hline 45 & 45 & het HBO moet een brede opleiding op het lewen geven \\
\hline 24 & 24 & het $\mathrm{HBO}$ moet meer algemeen vormende vakken bieden \\
\hline 106 & 106 & het $H B O$ moet wooral algemene kwalificatjes bieden \\
\hline \multirow[t]{2}{*}{91} & 91 & algemeen opleidend $\mathrm{HBO}$ als wenselijkheid \\
\hline & & Specifiek opleidend $\mathrm{HBO}(\mathrm{CONC}$ 42) \\
\hline 92 & 92 & specifiek opleidend $\mathrm{HBO}$ als wenselijkheid \\
\hline 42 & 42 & het $\mathrm{HBO}$ moet vooral specifiek opgeleide studenten vormen \\
\hline
\end{tabular}

Interpretatie van de concepten binnen factor $I V$ :

De dimensie "algemeen/specifieke opleiding" (FACTOR IV) blijkt te zijn samengesteld uit uitspraken die op verschillende analyse-niveaus zijn geformuleerd. Verondersteld werd dat de respondenten een onderscheid zouden maken tussen algemeen en specifiek opgeleide studenten enerzijds versus algemeen en specifiek onderwijs anderzijds. Het blijkt echter dat men dit onderscheid niet hanteert, getuige de samenvoeging van dergelijke uitspraken tot twee concepten. De dimensie (FACTOR IV) bestaat uit twee concepten, breed/algemeen HBO en specifiek beroepsgericht HBO (respectievelijk CONC. 41 en CONC. 42). Ook voor deze concepten geldt dat het onderscheid niet scherp wordt gehanteerd $(r=-.38$, vgl. blad 4, bijlage IV).

\subsubsection{De factoriële structuur binnen relevante subgroepen}

Nadat de factorinterpretatie was vastgesteld, deed zich de vraag voor of de aldus voor de totale groep van informanten gevonden dimensionele structuur ook geldt woor relevante subgroepen. Wij konden niet volstaan met een analyse en een interpretatie van de gevonden structuur van hoofdlijnen. Het werd (gelet op het gestelde in de hoofdstukken $3 \mathrm{t} / \mathrm{m}$ 5) van belang geacht te onderzoeken of de positie die de informanten hadden, in de afzonderlijke beoordeling een punt van betekenis was.

Gegeven de geconstateerde spanningsbronnen tussen de systemen "onderwijs" en "arbeid" lag het voor de hand na te gaan of de voor de totale groep experts (die vanuit verschillende sectoren bij het vraagstuk betrokken zijn) gevonden conceptuele denksystemen dezelfde was als voor specifieke subgroepen van experts. Met name of er verschillen in beoordelingssystemen waren tussen representanten uit de onderwijs- en arbeidswereld. Dezelfde vraag is relevant als we letten op het verschil in gevolgde opleiding van de respondenten. 
Gelet op het feit dat enkele subpopulaties slechts kleine aantallen respondenten bevatten is de analyse deels doorgevoerd via de Elementary Linkage Analysis van McQuitty. Zonder mathematisch-technische volledigheid te willen nastreven hebben wij acht geslagen op deze factoriële invariantieproblematiek. We hebben nagegaan of voor de gevormde subpopulaties van informanten uit verschillende sectoren en met een verschillende opleidingsachtergrond de conceptuele denkstructuur globaal hetzelfde is. Dit betekende - uit analyseoogpunt - dat de gevonden factorstructuren in de subpopulaties gelijk moesten zijn aan de over-all-structuur (de structuur o.b.w. de data van de gehele steekproef). Dit proces is doorgevoerd en we kunnen op basis van de uitkomsten ervan concluderen tot het volgende:

- De ook via deze methode gevonden clusters wijken niet af van de oplossing zoals die geldend was voor de totale steekproef. De conceptuele denksystemen zijn per subgroep nagenoeg hetzelfde.

- De sterkte der samenhangen is van dien aard dat nagenoeg alle variabelen in het netwerk verschijnen.

- De clustering der variabelen binnen de subpopulaties is zodanig dat de oorspronkelijke factoren én concepten herkenbaar zijn.

We concluderen dat - globaal - de conceptuele systemen voor de specifieke subgroepen informanten (naar sector en opleidingsachtergrond) gelijk zijn, met deze kanttekening dat het niet mogelijk was het zuiver gemeenschappelijk deell op te sporen en dat een aantal malen de omvang van de subpopulatie te gering was om overeenkomsten en verschillen exact te bepalen. Het feit dat de conceptuele systemen voor specifieke subgroepen van informanten nagenoeg dezelfde waren, betekent op zichzelf al een relativering van de traditionele tegenstelling tussen onderwijs en arbeid, zoals die in literatuur en discussies frequent wordt gepresenteerd.

Wij zullen op verschillen in visies tussen bepaalde subgroepen nog nader ingaan, maar kunnen nu reeds vaststellen dat het verschil in positie niet samengaat met fundamentele verschillen in de wijze van beoordeling: mensen met een verschillende achtergrond qua werkzaamheid en genoten opleiding hanteren dezelfde denkkaders bij de door ons onderzochte problematiek.

\subsection{RESUME MET BETREKKING TOT DE AANGETROFFEN DIMENSIES}

Als algemene conclusie geldt dat de dimensionele structuur gemeten over de scores van alle respondenten, alsmede de dimensionele structuur in enkele 
specifieke subgroepen (qua sector en qua opleiding) nagenoeg gelijk aanwezig is. Dat wil zeggen dat de door ons gehanteerde en aangebrachte conceptuele structuur blijkt te passen op de wijze waarop relevante actores die door ons zijn geraadpleegd, de hoofd- en subaspecten duiden en waarderen.

- Uit het geheel van uitspraken komen zes dimensies naar voren. Twee van deze dimensies hebben expliciet betrekking op de kwaliteitseisen die men aan de toekomstige HBO-er stelt. Deze dimensies passen redelijk bij het onderscheid tussen sociaal-normatieve en technisch-instrumentele kwalificaties. De sociaal-normatieve dimensie omvat vier concepten, te weten zelfstandigheid, communicatieve vaardigheden, samenwerking en tenslotte organisatie en planning.

De technisch-instrumentele dimensie omvat twee concepten, het leidinggeven en de management ondersteunende technieken.

- De interactie en relatie van het $\mathrm{HBO}$ en de beroepspraktijk wordt beoordeeld vanuit de dimensie autonoom versus afhankelijk HBO. Binnen deze dimensie zijn drie concepten onderscheiden: de autonomie van het $\mathrm{HBO}$, de aard van de interactie en de afhankelijkheid van het HBO.

- De structuur en organisatie-aspecten wan het HBO worden primair beoordeeld en gezien in termen van flexibiliteit. Deze dimensie valt uiteen in interne en externe flexibiliteit.

- De dimensie algemeen versus specifiek HBO verwijst, evenals de dimensie flexibiliteit, naar de geaardheid van de $\mathrm{HBO}$-opleiding. Ook hier zijn twee subdimensies aangetroffen: algemeen opleidend HBO versus specifiek opleidend beroepsgericht HBO.

- De dimensie regelgeving verwijst naar de context waarbinnen overleg over werken aan de relatie $\mathrm{HBO}$ en beroepspraktijk zich bevindt.

\subsection{SAMENVATTENDE BESCHOUWING}

De principale componenten-analyse leidt tot een zestal hoofddimensies met betrekking tot het thema HBO en beroepspraktijk. Deze hoofddimensies zijn opnieuw geanalyseerd, waarbij bleek dat vijf van de zes uiteenvielen in - in totaal - dertien concepten.

Deze concepten vormen een afspiegeling van de visies inzake de kwaliteit van de $\mathrm{HBO}-\mathrm{er}$, de aard van de interactie tussen $\mathrm{HBO}$ en beroepspraktijk en de ontwikkeling die het HBO qua structuur en organisatie had. Onderscheiden groepen van experts hanteerden daarbij dezelfde denkkaders. 


\section{Het onderzoek naar prioriteiten en patronen}

\subsection{INLEIDING}

In dit hoofdstuk gaan wij na wat de verschillen en overeenkomsten in de scores van de diverse subgroepen van respondenten zijn met betrekking tot de concepten die in het vorige hoofdstuk zijn beschreven. Wij gaan eerst na wellke rangordening bestaat in de wensellijkheid die aan diverse aspecten werd toegekend (par. 8.2). Daarna onderzoeken wij welke verschillen in visies er optreden. Via enkelvoudige variantie-analyse zijn deze verschillen opgespoord. Daarbij wordt onder de nulhypothese verwacht dat de gemiddelden van de diverse subgroepen gelijk zijn. Indien er een significant verschil bestaat, dan wil dat nog niet zeggen dat het een relevant verschil is. Wij hanteren als relevantie-maat een associatiecoëfficiënt met een minimale waarde van .15 als criterium. (ETA; als associatiemaat op intervalniveau en Cramers $\mathrm{V}$ als associatie-coëfficiënt bij tabelanalyse met nominale variabelen). Ter illustratie van het globale beeld van opgespoorde visies gaan wij eerst in op het aspect van de rangorde qua toegekende wenselijkheden.

\subsection{DE PRIORITETT VAN DE CONCEPTEN}

Nadat wij in het vorige hoofdstuk hebben vastgesteld hoe in grote lijnen de beoordeling plaatsvindt, doet zich de vraag voor welke aspecten respondenten nu het meest wenselijk achten in het beoordelen van de toekomstige relatic van $\mathrm{HBO}$ en beroepspraktijk.

Om deze vraag te kunnen beantwoorden is van de gevonden concepten een additieve schaal geconstrueerd. Deze additieve schalen gaan uit van de ruwe scores op variabelen die behoren tot een concept. De ruwe scores worden opgeteld en gedeeld door het aantal respondenten. De schaal heeft dan dezelfde lengte als de continua van de variabelen (in ons geval van $1 \mathrm{t} / \mathrm{m} 5$ ). Dergelijke schalen staan bekend onder de naam Likertschalen (vgl. Swanborn, 1982). Wij hebben voor de leesbaarheid alle gevonden waarden met 100 vermenigvuldigd; hoe hoger de score hoe wenselijker het desbetreffende aspect 
wordt beschouwd. Een score van 100 komt overeen met een minimale, 500 met een maximale wenselijkheid.

Er zijn twee aspecten van deze schaalconstructie die aandacht verdienen: het probleem van ontbrekende scores (de $\mathrm{zg}$. "missing values") en de betrouwbaarheid van de schaal. Voor de ontbrekende antwoorden van een respondent op een of meer variabelen is een veel gebruikte schattingsprocedure gebruikt. Als een respondent op minder dan de helft minus $1\left(1 / 2^{*}(\mathrm{P}-1)\right)$ van het aantal variabelen $(P)$ uit een schaal geen antwoord heeft gegeven, dan nemen we aan dat de persoon in kwestie het patroon van de wel gegeven antwoorden volgt. In alle andere gevallen beschouwen we de schaalscore als ontbrekend. Het aantal ontbrekende gegevens blijkt relatief laag te zijn (maximaal 3,8\%). De betrouwbaarheid van de gevonden schalen wordt uitgedrukt in de $\mathrm{zg}$. Cronbach's alpha betrouwbaarheidscoëfficiënt. De essentie van de procedure is het opsplitsen van de gegevens in gelijke parallelle delen, het apart meten van die delen en het vervolgens bepalen in hoeverre de resultaten van die metingen overeenkomen ( $\mathrm{ggl}$ Swanborn, 1982). In bijlage IV zijn deze betrouwbaarheidscoscoscoëfficiënten per schaal weergegeven. Vijf van de dertien schallen hebben een betrouwbaarheid van minder dan .70. Dat is minder dan de gangbare normen voorschrijven (vgl Nunnally, 1978, p. 162).

De prioriteit van de concepten als kernaspecten die in de relatie $\mathrm{HBO}$ en beroepspraktijk het meest gewenst worden, is af te leiden uit de hoogte van de gemiddelde scores op de concepten. Het meest gewenste aspect heeft het hoogste gemiddelde.

De relatief hoge gemiddelden (groter dan 400) wijzen erop dat zelfstandigheid, het kunnen organiseren van het eigen werk en het bezit van communicatieve vaardigheden van de $\mathrm{HBO}$-er als meest wenselijke eigenschappen worden gezien (respectieve gemiddelden 426, 410 en 432). Nog sterker valt de nadruk op de aard van de interactie (460). Minder wenselijk, maar zeker niet ongewenst, zijn de interne en externe flexibiliteit van het HBO, breed HBOonderwijs en specifiek HBO-onderwijs.

Opmerkelijk is verder dat de instemming met "Autonoom HBO" het laagst scoort (165). Kennelijk is men over het algemeen minder geporteerd voor dit idee. Tabel 28 op de volgende bladzijden, geeft een inzicht in de scores op en de rangorde van de concepten, opgevat als additieve schalen, zoals boven omschreven. 
Tabel 28: Essentie, gerniddelde score $(X)$, standaardafiwijking $(S)$, aantal $(N)$ en Cronbachs alpha (a) van de schalerd, gepresenteerd in de reeks meest-minst geprejereerd

\begin{tabular}{|c|c|c|c|c|c|c|c|}
\hline schalal/concept: c & $\begin{array}{l}\text { concept- } \\
\text { no }\end{array}$ & domein & essentie & $x$ & $s$ & $\mathrm{~N}$ & a \\
\hline $\begin{array}{l}\text { Aard wan de } \\
\text { interactie }\end{array}$ & 22 & $\begin{array}{l}\text { Inter- } \\
\text { actie }\end{array}$ & $\begin{array}{l}\text { HBO wolgt ontwikkelingen } \\
\text { in beroepspraktijk/is } \\
\text { bereid tot open dialoog. }\end{array}$ & 460 & 56 & 361 & .61 \\
\hline $\begin{array}{l}\text { Comm. vaardig- } \\
\text { heden }\end{array}$ & 12 & $\begin{array}{l}\text { Kwalli- } \\
\text { teit }\end{array}$ & $\begin{array}{l}\text { Schriftelijke/mondelinge } \\
\text { uitdrukkingswaardigheden } \\
\text { en rapportagetechniek }\end{array}$ & 432 & 64 & 355 & .76 \\
\hline $\begin{array}{l}\text { Zelfstandig- } \\
\text { hei }\end{array}$ & 11 & $\begin{array}{l}\text { Kwali- } \\
\text { teit }\end{array}$ & $\begin{array}{l}\text { Ideeën ontwikkelen/ } \\
\text { initiatieven nemen, } \\
\text { keuzen doen }\end{array}$ & 426 & 59 & 354 & 81 \\
\hline $\begin{array}{l}\text { Organisatie en } \\
\text { planning }\end{array}$ & 14 & $\begin{array}{l}\text { Kwali- } \\
\text { teit }\end{array}$ & $\begin{array}{l}\text { Organiseren van eigen } \\
\text { werk en van werk van } \\
\text { anderen/samenwerking } \\
\text { collegae }\end{array}$ & 410 & 65 & 355 & .78 \\
\hline Samenwerking & 13 & $\begin{array}{l}\text { Kurali- } \\
\text { teit }\end{array}$ & $\begin{array}{l}\text { Samenwerking met exter- } \\
\text { ne wrijwilligers/supe- } \\
\text { rieuren partijen/ }\end{array}$ & 375 & 78 & 354 & .75 \\
\hline Leiding geven & 51 & $\begin{array}{l}\text { Kwali- } \\
\text { teit }\end{array}$ & $\begin{array}{l}\text { Organisatiegebonden } \\
\text { taken/beleidsontwikkeling }\end{array}$ & 372 & 71 & 351 & .77 \\
\hline $\begin{array}{l}\text { Managementtech- } \\
\text { nieken }\end{array}$ & $1-52$ & $\begin{array}{l}\text { Kowali- } \\
\text { teit }\end{array}$ & $\begin{array}{l}\text { Technieken voor onder- } \\
\text { zoek/marketing en bud- } \\
\text { getbewaking }\end{array}$ & 352 & 79 & 348 & .77 \\
\hline Afhankelijk & 23 & $\begin{array}{l}\text { Inter- } \\
\text { actie }\end{array}$ & $\begin{array}{l}\text { HBO is afhankelijk van } \\
\text { ontwikkelingen in de } \\
\text { beroepspraktijk en moet } \\
\text { daardoor worden bepaald }\end{array}$ & 349 & 84 & 362 & .63 \\
\hline $\begin{array}{l}\text { Externe llexi- } \\
\text { biliteit }\end{array}$ & 32 & $\begin{array}{l}\text { Sitruc- } \\
\text { tuwr en } \\
\text { organi- } \\
\text { satie }\end{array}$ & $\begin{array}{l}\text { HBO in beroepspraktijk } \\
\text { integreren/meer stages/ } \\
\text { leerlingstelsel- } \\
\text { concept overwegen }\end{array}$ & 338 & 88 & 356 & .70 \\
\hline Breed $\mathrm{HBO}$ & 41 & $\begin{array}{l}\text { Struc- } \\
\text { tuur en } \\
\text { organi- } \\
\text { satie }\end{array}$ & $\begin{array}{l}\text { Brede opleiding/algemeen } \\
\text { vormend/algemene kwalifi- } \\
\text { caties }\end{array}$ & 301 & 82 & 358 & .75 \\
\hline $\begin{array}{l}\text { Interne flexi- } \\
\text { biliteit }\end{array}$ & 31 & $\begin{array}{l}\text { Struc- } \\
\text { tuur en } \\
\text { organi- } \\
\text { satie }\end{array}$ & $\begin{array}{l}\text { HBO in kleine eenheden/ } \\
\text { gedecentraliseerd/ } \\
\text { geindividualiseerd aan- } \\
\text { bieden en organiseren }\end{array}$ & 273 & 69 & 354 & .68 \\
\hline
\end{tabular}


Verolg tabel 28: Essentie, gemiddelde score $(X)$, standaardafwijking (S), aantal (N) en cronbachs alpha (a) van de schaien, gepresenteerd in de reeks meest-minst geprefereerd

\begin{tabular}{llllllll}
\hline schaal/concept: & $\begin{array}{l}\text { concept- domein } \\
\text { no }\end{array}$ & essentie & $X$ & $S$ & $N$ & a \\
\hline Specifiek HBO & 42 & $\begin{array}{l}\text { Struc- } \\
\text { tuur en } \\
\text { organi- } \\
\text { satie }\end{array}$ & $\begin{array}{l}\text { Specifiek functiegericht } \\
\text { opleidend HBO }\end{array}$ & 263 & 92 & 350 & .63 \\
\hline Autonoom HBO 211 & $\begin{array}{l}\text { Inter- } \\
\text { actie }\end{array}$ & $\begin{array}{l}\text { HBO als autonoom insti- } \\
\text { tuut dat zelf beroeps- } \\
\text { praktijkeisen bepaalt } \\
\text { verschil in sfeer met } \\
\text { beroepspraktijk }\end{array}$ & 165 & 72 & 362 & 65 \\
\hline
\end{tabular}

De gemiddeiden geven de toegekende mate van wenselijkheid aan. De alphas verwijzen naar de betrouwbaarheid en de standaardafwijkingen zijn een mat voor de spreiding. De gemiddelden kunnen op verschillende manieren tot stand komen; enkele uitschieters bujvoorbeeld kunnen woor vertekening zorgen. Ook kan de frequentieverdeling meertoppig zijn. Inspectie van de frequentie. verdelingen laat zien dat de gemiddelden niet vertekend zijn, noch door dergelijke uitschieters, noch door meertoppigheid.

\subsection{DE EERSTE RESULTATEN VAN HET ONDERZOEK NAAR VERSCHILLEN IN VISIES}

In tabel 29 hebben wij het resultaat van de analyses samengevat. Enkele punten vallen daarbij op. Ten eerste blijkt dat de rangordening van de concepten, zoals die eerder is vastgesteld, niets zegt over het verschil in denken over een bepaald concept binnen bepaalde subgroepen. Wij komen hierop in dit hoofdstuk terug. Ten tweede lijken ten aanzien van een aantal kwesties de meningen minder te divergeren dan verwacht: Een aantal concepten laat geen relevante associaties zien. Het gaat hierbij om:

concept 12 communicatieve vaardigheden (uitdrukkingsvaardigheid in woord en geschrift)

concept $21=$ autonoom $\mathrm{HBO}$ (HBO als instituut dat zelf eisen bepaalt) concept 22 = de aard van de interactie (actief omgevingsgericht $\mathrm{HBO}$ ) concept 42 = specifiek opleidend HBO (specifiek functiegerichte opleiding) concept 51 = leidinggeven (ontwikkelen van visies, beleid; leiden van mensen)

Het zijn vooral de concepten verbandhoudend met interactie (de relatie van onderwijs- en beroepspraktijk) die geen relevante verbanden opleveren en - merkwaardig genoeg - zorgen voor de minste divergenties in visies. Merkwaardig, omdat in de literatuur het beeld opdoemt van een gecompliceerde 
verhouding en tal van momenten van spanning in de relatie van onderwijsen beroepspraktijk. Essentieel is dat de autonomie van het HBO (21) en de aard van de interactie (22) geen verschillen qua visies laten zien.

Specifiek opleidend HBO (42) (overigens al eerder als relatief laag geprefereerd aspect opgevallen (zie tabel 28)) laat geen enkele relevante associatie met achtergrondkenmerken zien evenals het aspect communicatieve vaardigheden (12) en leidinggeven (51). Vervolgens blijkt dat een aantal sociale achtergrondkenmerken geen rol van betekenis speelt. De vraag naar gelijkheid van opleiding en werk (V4) bijvoorbeeld, was bedoeld om na te gaan of degenen die de aansluiting wan opleiding en werk "aan den lijve" hadden ondervonden anders zouden denken dan degenen die vanuit de opleiding in het aansluitende beroepenveld doorstroomden. Dat kenmerk en de duur van werkzaamheid (zowel V5 en V6) blijken geen rol te spelen.

Overzien wij het geheel, dan blijken met name de soort van de genoten opleiding (V3), de positie (V7), de betrokkenheid bij discussies en beleidsontwikkeling (resp. V10 en V11) alsmede de reputatie (ID) meer te kunnen zeggen over de verschillen tussen diverse groepen.

Het volgende overzicht geeft een beeld van relevante samenhangen tussen kenmerken van respondenten en scores van bepaalde subpopulaties op beoordelingsdimensies. Niet-significante en niet-relevante samenhangen zijn daarin niet opgenomen. In tabel 29 zijn de betrokkenheidsvariabelen (V10 en V11) gedichotomiseerd, waarbij de categorieën 1,2 en 3 als "niet of nauwelijks betrokken" worden beschouwd en de categorieën 4 en 5 als "wel betrokken".

In de volgende paragrafen worden de kwaliteits- en interactie-aspecten besproken. In paragraaf 8.6 komen de structuur- en organisatie-aspecten aan de orde. In paragraaf 8.7 vatten wij de resultaten kort samen. 


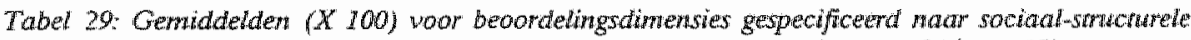
achtergrondkemmerken (alleen relevante samenhangen zijn vermeld/eta: .15)

\begin{tabular}{|c|c|c|c|c|c|c|c|c|}
\hline \multirow{2}{*}{$\begin{array}{l}\text { Sociale structurele } \\
\text { keamerken }\end{array}$} & \multirow[b]{2}{*}{11} & \multirow[b]{2}{*}{13} & \multirow[b]{2}{*}{14} & \multicolumn{3}{|c|}{ Schaalnumner } & \multirow[b]{2}{*}{41} & \multirow[b]{2}{*}{52} \\
\hline & & & & 23 & 31 & 32 & & \\
\hline \multicolumn{9}{|l|}{ OPLEIDING $(\sqrt{3})$} \\
\hline Sociaal-pedagogische opleiding & & 385 & & 334 & 285 & & & \\
\hline Economisch/admin.opleiding & & 360 & & 353 & 268 & & & \\
\hline Technische opleiding & & 365 & & 382 & 256 & & & \\
\hline \multicolumn{9}{|l|}{ POSITIE (V7) } \\
\hline Arbeid & 420 & 365 & 424 & 355 & 266 & & & \\
\hline Onderwijs & 433 & 397 & 458 & 317 & 283 & & & \\
\hline Intermediair & 446 & 394 & 433 & 375 & 302 & & & \\
\hline \multicolumn{9}{|l|}{ INGRAAD-INDEX (ID) } \\
\hline Niet genoemd & & & & & 287 & 358 & 314 & \\
\hline Eenmaal genoend & & & & & 256 & 318 & 286 & \\
\hline Meer dan eenmaal genoemd & & & & & 270 & 329 & 296 & \\
\hline \multirow{2}{*}{\multicolumn{9}{|c|}{ BESLISSENDE INVLOED (V9) }} \\
\hline Niet of nauwelijks betrokken & & & & & & & & \\
\hline Wel betrokken & & 405 & & & & & & \\
\hline \multicolumn{9}{|l|}{ BETROKKENHEID BUJ } \\
\hline \multicolumn{9}{|l|}{ DISCUSSIE (V10) } \\
\hline Niet of nauwelijks betrokken & & & 425 & & & & & \\
\hline Wel betrokken & & & 446 & & & & & \\
\hline \multicolumn{9}{|l|}{$\begin{array}{l}\text { BETROKKENHEID BELEIDS- } \\
\text { ONTWIKKELING }(V 11)\end{array}$} \\
\hline Niet of nauwelijks betrokken & & 369 & 428 & & & & & 346 \\
\hline Wel betrokken & & 416 & 456 & & & & & 390 \\
\hline \multicolumn{9}{|l|}{$\begin{array}{l}\text { Schaalgemiddelden voor de } \\
\text { gehele onderzoekspopulatie }\end{array}$} \\
\hline (zie tabel 28): & 426 & 375 & 432 & 349 & 273 & 338 & 301 & 352 \\
\hline Standaardafwijking & 59 & 78 & 64 & 84 & 69 & 88 & 82 & 79 \\
\hline
\end{tabular}

Legenda schaalnumners:
11: zelfstandigheid
31: interne flexibiliteit
13: samenwerking
32: externe flexibiliteit
14: organisatie en planning
23: afhankelijk HBO
41: breed opleidend $\mathrm{HBO}$
52: managementtechnicken

\subsection{PRIORTEITEN BINNEN HET DOMEIN KWALITEIT}

Tabel 29 laat zien dat van de zes oorspronkelijke kwaliteitsaspecten drie aspecten verschillend worden beoordeeld door de informanten uit de arbeidssector, het onderwijs en de intermediaire organisaties. Zelfstandigheid (concept 11) als aspect waarop het toekomstig HBO bij de beroepswoorbereiding vooral zou moeten letten, wordt hoog aangeslagen door de intermediaire sector en 
het minst door de arbeidssector, terwijl het onderwijs het midden houdt (respectievelijke gemiddelden 446,420 en 433 ).

Samenwerking (concept 13, opgevat als in- en extern samenwerken, omgaan met mensen binnen en buiten de werkorganisatie) wordt daarentegen vooral benadrukt door het onderwijs en de intermediaire sector, terwijl de arbeidssector daar minder wenselijkheid aan toekent (resp. 397, 394 en 365). Organisatie en planning (concept 14, opgevat als de vaardigheid eigen en andermans werk te orgamiseren en samen te werken met collegae) worden het meest wenselijk geacht door de sector onderwijs (gemiddelde 458), terwijl de intermediaireen de arbeidssector daar min of meer hetzelfde over denken (resp. 433 en 424). Opvallend bij deze drie aspecten is dat het telkenmale de arbeidssector is die het meest terughoudend scoort qua toegekende wenselijkheden.

We kunnen zien dat er relevante verbanden zijn tussen visies op "organisatie en planning" (14) en positie (V7) alsmede visies op "management ondersteunende technieken" (52) en betrokkenheid bij beleidsontwikkeling (V11). Verwezen wordt naar tabel $30 \mathrm{~A}$ en $30 \mathrm{~B}$.

Tabel 30A: ORGANISATIE EN PLANNING (CONCEPT 14) ALS KWALITETSKENMERK GESPECIFICEERD NAAR POSITIE (VT) (Percentages tussen haakjes)

\begin{tabular}{lllll}
\hline $\begin{array}{l}\text { Positie (V7) } \\
\text { CONC 14 }\end{array}$ & A.rbeid & Onderwijs & Intermediair & Totaal \\
\hline $50 \%$ Laag & $150(63)$ & $28(38)$ & $21(53)$ & $199(57)$ \\
$50 \%$ Hoog & $89(37)$ & $45(62)$ & $19(47)$ & $153(43)$ \\
\hline Totaal & $239(100)$ & $73(100)$ & $40(100)$ & $352(100)$ \\
\hline
\end{tabular}

Chi-kwadraat $=13.8(\mathrm{p}<.05)$

Cramer's $V=.19$

Tabel 30B: MANAGEMENT-ONDERSTEUNENDE TECHNIEKEN (CONCEPT 52) ALS KWALITEITSKENMERK GESPECIFICEERD NAAR BELEIDSBETROKKENHEID (V11) (Percentages tussen haakjes)

Betrokken bij beleid (V11)

\begin{tabular}{llll} 
CONC 52 & Niet & Wel & Totaal \\
\hline $50 \%$ Laag & $117(61)$ & $18(35)$ & $195(57)$ \\
$50 \%$ Hoog & $114(39)$ & $33(65)$ & $147(43)$ \\
\hline Totaal & $291(100)$ & $51(100)$ & $342(100)$ \\
\hline
\end{tabular}

Chi-kwadrat $=10.5(\mathrm{p}<.05)$

Cramer's $\mathrm{V}=.17$ 
Organisatie en planning als kwaliteitsaspecten worden door informanten uit de sector onderwijs wenselijker geacht dan door mensen uit de sector arbeid ( $63 \%$ vs $37 \%$ ), terwijl de informanten uit de intermediaire organisatie daarover kennelijk niet zo verschillend denken.

Binnen de categorieën van betrokkenheid bij beleid blijkt thet verband tussen positie en organisatie/planning alleen te bestaan binnen de groep die zich wel betrokken acht: het zijn voornamelijk de actief in het beleid participerende onderwijsmensen die meer nadruk leggen op organisatie/ planning. De actief participerenden uit de sector arbeid denken daar niet zo eensluidend over (onderwijs $71 \%$ en arbeid $41 \%$ ). Zie tabel 31 .

Tabel 31: ORGANISATIE EN PLANNING (CONCEPT 14) ALS KWALITEITSKENMERK GESPECIFICEERD NAAR DE SECTOREN ARBEID EN ONDERWIUS EN BELEIDSBETROKKENHEID (VIl) (Percentages tussem haakjes)

\begin{tabular}{|c|c|c|c|}
\hline $\begin{array}{l}\text { Organisatie en planning } \\
\text { CONC } 14\end{array}$ & $\begin{array}{l}\text { Niet bet: } \\
\text { Arbeid }\end{array}$ & $\begin{array}{l}\text { kken bij beleid } \\
\text { Onderwijs }\end{array}$ & Totaal \\
\hline $\begin{array}{l}50 \% \text { Laag } \\
50 \% \text { Hoog }\end{array}$ & $\begin{array}{r}139(63) \\
81(37)\end{array}$ & $\begin{array}{l}16(47) \\
18(53)\end{array}$ & $\begin{array}{r}155 \\
99\end{array}$ \\
\hline \multirow[t]{2}{*}{ Totaal } & $220(100)$ & $34(100)$ & $254(100)$ \\
\hline & \multicolumn{2}{|c|}{$\begin{aligned} \text { Chi-kwadraat } & =3.22(\mathrm{p}>.05) \\
\text { Phi } & =.11\end{aligned}$} & \\
\hline $\begin{array}{l}\text { Organisatie en planning } \\
\text { CONC } 14\end{array}$ & \multicolumn{2}{|c|}{$\begin{array}{l}\text { Well betrokken bij beleid: } \\
\begin{array}{ll}\text { Arbeid } & \text { Onderwijs }\end{array}\end{array}$} & Totaal \\
\hline $\begin{array}{l}50 \% \text { Laag } \\
50 \% \text { Hoog }\end{array}$ & $\begin{aligned} & 10(59) \\
& 7(41)\end{aligned}$ & $\begin{array}{l}10(29) \\
25(71)\end{array}$ & $\begin{array}{l}20 \\
32\end{array}$ \\
\hline \multirow[t]{2}{*}{ Totaal } & $17(100)$ & $35(100)$ & $52(100)$ \\
\hline & \multicolumn{2}{|c|}{$\begin{aligned} \text { Chi-kwadraat } & =4.42(\mathrm{p}<.05) \\
\text { Phi } & =.29\end{aligned}$} & \\
\hline
\end{tabular}

Ervan uitgaande dat betrokkenheid bij het beleid impliceert dat men ook aan discussies deelneemt, moet een identiek verband als bovenbeschreven onder de condities van discussie-betrokkenheid (V10) te vinden zijn. Dit bleek inderdaad het geval te zijn ( $\mathrm{Phi}=.23$ ). We kunnen deze lijn doortrekken naar het aspect reputatie. Betrokkenheid bij discussies of beleid houdt in dat er een bepaalde "zichtbaarheid" bestaat, dat wil zeggen de reputatie is mede afhankelijk van de mate waarin men in allerlei groepen en fora participeert. Wij hebben de ingraad (ID) gedichotomiseerd, waarbij niet of slechts eenmaal genoemd geldt als "geen reputatie". Ook hier bleek een sterk verband te 
bestaan tussen positic en organisatie/ planning binnen de groep met een reputatie (Cramer's $\mathrm{V}=.29$ ).

Als wij visies specificeren volgens de door informanten genoten opleiding, dan kunnen wij om technische redenen alleen de onderwijssector vergelijken met de arbeidssector. Gelet op de geringe aantallen respondenten in deze subcategorieen, kon door te lage aantallen in de oorspronkelijke cellen geen betekeniswolle analyse worden doorgevoerd. Daarbij blijkt oplleiding geen rol van betekenis te spelen op de verdeling over de sectoren. De partiële tabellen van positie en organisatie/planning onder constanthouding van opleiding vertonen nagenoeg dezelfde samenhang als de oorspronkelije tabel.

Identieke analysestappen zijn gezet met betrekking tot het aspect "management ondersteunende technieken" (verder af te korten als "management"). Dit concept impliceert fondswerving, budgetbeheer, research en marketing. Visies op dit aspect hangen samen met de betrokkenheid bij beleidsontwikkeling. Dit verband verdwijnt binnen de sector onderwijs, maar blijft binnen de sector arbeid $(\mathrm{Phi}=.18)$. Dit betekent dat betrokkenheid bij beleidsontwikkeling binnen onderwijs geen rol speelt. Anders ligt dit bij de arbeidssector: de actief participerenden leggen meer nadruk op managementtechniek dan de niet-participerenden (64\% ws. $36 \%$ ).

Betrokkenheid bij beleidsontwikkeling speelt geen rol bij mensen met een economisch-administratieve of technische opleiding; daarentegen differentieert het beeld wel binnen de groep sociaal-pedagogisch opgeleiden. Het betrokken zijn in beleidsontwikkeling leidt tot een grotere nadruk op managementtechniek als kwaliteitseis, dan het niet betrokken zijn (75\% vs $38 \%$, Phi $=.29$ ).

Samenvattend: van de zes aspecten met betrekking tot kwaliteit blijken "organisatie/planning" en "managementtechnieken" verschillen op te leveren die samenhangen met positie en betrokkenheid bij beleidsontwikkeling. Het aspect organisativ/planning blijkt vooral benadrukt te worden door onderwijsmensen die zelf actief participeren in beleidsontwikkeling.

Dit is een beeld dat bevestigd wordt als wij letten op de toegekende reputatie: ook hier zijn het onderwijsmensen met een reputatie die organisatie/planning als een gewenste eigenschap van de HBO-er vooral benadrukken. Managementtechnieken als gewenst aandachtspunt in de beroepswoorbereiding door het $\mathrm{HBO}$ wordt vooral door mensen uit de arbeidsector geprefereerd en daarbinnen vooral door hen die actief bezig zijn met beleidsontwikkeling. Het dimensionaliseringsonderzoek bracht al aan het licht dat de denkkaders van - onder andere - subgroepen wit de sectoren arbeid en onderwijs dezelfde 
zijn. Bezien wij de zes kwaliteitsaspecten (concepten opgevat als schalen) dan valt op dat het vooral de "sociaal normatieve" aspecten wan het kwaliteitsdomein zajn die zowel hoog geprefereerd worden (vgl tabel 29) alsook de meeste - relevante - associaties met sociale achtergrondkenmerken laten zien. In hoofdstuk 9 komen wij op de conclusies terzake nog terug.

\subsection{PRIORTEITEN BINNEN HET DOMEIN INTERACTIE}

Bimnen dit probleemveld wordt door de informanten duidelijk verschillend gedacht over de richting waarin afhankelijkheid van het HBO ten opzichte van de beroepspraktijk moet gaan. De autonomie van het HBO is merkwaardig genoeg geen punt dat visies sterk doet divergeren, evenmin als de gewenste aard van de interactie. Een autonoom HBO (waarbij de sfeer van $\mathrm{HBO}$ en beroepspraktijk duidelijk verschillend is en het HBO de markteisen bepaalt) wordt niet gewenst. Eent attent volgend $\mathrm{HBO}$, in een actieve interactie met beroepspraktijk, daarentegen wordt door iedereen sterk benadrukt (zie tabel 28).

Indien wij afgaan op de aard van de genoten opleiding blijkt het volgende: Het zijn de technisch opgeleide informanten die meer nadruk leggen op een afhankelijk HBO, sociaal-pedagogisch opgeleiden achten dit aspect minder gewenst, terwijl economisch-administratief opgeleiden het midden houden tussen deze twee stellingen.

Vanuit de positie bezien is het de intermediaire sector die een ten opzichte van de beroepspraktijk afhankelijk HBO benadrukt, gevolgd door de sector arbeid. Onderwijsinformanten vinden een afhankelijk $\mathrm{HBO}$ duidelijk minder wenselijk. Hierbij moet worden aangetekend dat de relatieve hoogte van de schaalscores aangeven dat men zich over het algemeen niet duidelijk uitspreekt over een afhankelijk $\mathrm{HBO}$. De strategie uit de vorige paragraaf volgend voor de interactie-aspecten laat zien dat alleen het aspect afhankelijkheid van het HBO samenhangt met de opleiding en de positie. Verwezen wordt naar tabel 32. Informanten uit de intermediaire sector achten de afhankelijkheid van het HBO kennelijk een meer wenselijk discussiethema dan mensen uit het onderwijs (resp. $69 \%$ vs. $33 \%$ ).

Kijken we naar opleiding, dan blijken mensen met een technische opleiding de wenselijkheid van een afhankelijk HBO te benadrukken. Dit verband ligt omgekeerd voor mensen met een sociaal-pedagogische opleiding (resp. $72 \%$ vs. $47 \%$ ). Om technische redenen trekken wij de opleidingscategorieën "economisch-administratief" en "technisch" samen en vergelijken de aldus gevormde 
categorie met de "sociaal-pedagogen". Voorts betrekken wij alleen de groepen arbeid en onderwijs in de wergelijking. Binnen arbeid en onderwijs speelt de opleiding (gedichotomiseerd als boven beschreven) kennelijk geen rol: de aard van de opleiding zegt niets over de mate van een gewenst afhankelijk HBO. Een verband tussen opleiding en een hoge score op de schaal "afinankelijk $\mathrm{HBO}^{\prime \prime}$ bestaat wel binnen de groep zonder een reputatie $(\mathrm{Phi}=.15)$, maar niet in de groep mét een reputatie.

Tabel 32: AFHANKELIJK HBO ALS INTERACTIEKENMERK GESPECIFICEERD NAAR POSITIE (V7) RESP. OPLEIDING INFORMANT (V3) (Percentages tussen haakjes)

\begin{tabular}{|c|c|c|c|c|}
\hline $\begin{array}{l}\text { Afhankelijk } \mathbb{H B O} \\
\text { CONC } 23\end{array}$ & $\begin{array}{l}\text { Positie (V7) } \\
\text { Arbeid }\end{array}$ & Ondertwijs & Intermediair & Totaal \\
\hline $50 \%$ laag & $107(44)$ & $50(67)$ & $13(31)$ & $170(47)$ \\
\hline $50 \% \mathrm{Hoog}$ & $136(56)$ & $25(33)$ & $28(69)$ & $189(53)$ \\
\hline \multirow[t]{2}{*}{ Totaal } & $243(100)$ & $75(100)$ & $41(100)$ & $359(100)$ \\
\hline & \multicolumn{4}{|c|}{$\begin{array}{l}\text { Chi-kwadraat }=16.3(\mathrm{p}<.05) \\
\text { Cramer's V }=.21\end{array}$} \\
\hline $\begin{array}{l}\text { Afhankelijk } \mathrm{HBO} \\
\text { CONC } 23\end{array}$ & $\begin{array}{l}\text { Opleiding (V3) } \\
\text { Soc.pedag. }\end{array}$ & Econ-Admin. & Technisch & Totaal \\
\hline $50 \%$ Laag & $82(53)$ & $56(46)$ & $17(28)$ & $155(46)$ \\
\hline $50 \%$ Hoog & $74(47)$ & $66(54)$ & $43(72)$ & $183(54)$ \\
\hline Totaal & $156(100)$ & $122(100)$ & $60(100)$ & $338(100)$ \\
\hline
\end{tabular}

Chi-kwadraat $=10.2(\mathrm{p}<.05)$

Cramer's $V=.17$

Legenda

Soc,-pedag. = opleiding van sociaalwetenschappelijke of pedagogische aard

Econ-Admin. = opleiding wan economisch/administratieve aard

Technisch = opleiding van technische aard

Kennelijk verschillen de mensen met een reputatie op dit punt niet met elkaar van mening. Men zou nu kunnen verwachten dat een dergelijk verband ook binnen de categorieën van betrokkenheid bij de discussies zou optreden. Dit blijkt echter niet het geval te zijn. Met andere woorden: opleiding "verklaart" niet rechtstreeks de gewenste afhankelijkheid van het $\mathrm{HBO}$, maar loopt via betrokkenheid bij de discussies (V10). Eenzelfde beeld vinden wij bij betrokkenheid bij beleidsontwikkeling (V11).

Ook hier blijki (evenalls bij de kwaliteits-aspecten) dat de mate van betrokkenheid meer zegt over de visies dan de zogeheten "sociaal-structurele achtergrondkenmerken". 
Binnen de categorieën "niet betrokken" en "wel betrokken" laat het aspect positie ook verschillen zien: binnen de groep "well betrokken" is er een significant verband tussen positie en afhankelijkheid van het HBO als thema. 71 \% van de onderwijs-mensen is minder geporteerd voor een afhankelijk HBO tegen $43 \%$ van de arbeidsmensen. Het zijn de vertegenwoordigers uit de beroepspraktijk die duidelijk meer de nadruk leggen op de afhankelijkheid van het $\mathrm{HBO}$.

Samenvattend: Overzien we het domein van de interactie dan kunnen wij concluderen, dat een autonoom $\mathrm{HBO}$ en de gewenste aard van de interactie (in termen van een open dialoog en het volgen van ontwikkelingen in de beroepspraktijk) geen twistpunten vormen. Een sterk autonoom HBO wordt niet gewenst. Een interactie van $\mathrm{HBO}$ en beroepspraktijk waarbij het $\mathrm{HBO}$ de praktijk attent volgt en in een open dialoog staat met het werkveld wordt door allen sterk benadrukt. Daarentegen lijkt het thema "afhankelijk HBO" voor verdeeldheid te zorgen: er wordt minder prioriteit aan toegekend en er wordt verschillend over gedacht door mensen met een uiteenlopende opleidingsen arbeidsachtergrond.

Ook hier is de mate van betrokkenheid bij beleidsontwikkeling een belangrijk kenmerk, waarmee men diverse groepen kan onderscheiden.

Ten aanzien van de afhankelijkheid van het HBO zijn het vooral de mensen uit het onderwijs met een hogere reputatie die een tot de beroepspraktijk afhankelijk HBO minder wenselijk achten.

Wij stellen vast dat de interactie-schalen de meningen minder doen variëren dan verwacht werd in een benadering die uitging van tal van divergenties in visies, scherp te onderscheiden partijen en spanningsbronnen in de relatie onderwijs- en beroepspraktijk.

\subsection{PRIORITETEN BINNEN HET DOMEIN STRUCTUUR EN ORGANISATIE}

De aspecten die met betrekking tot de structuur van het HBO zijn onderzocht laten weinig verschillen zien. Bovendien wordt aan structuur-aspecten relatief een lage prioriteit toegekend. Variantie-analyse toont aan dat het voornamelijk de reputatie is die voor opmerkelijke verschillen zorgt, mensen zonder reputatie kennen aan interne en externe flexibiliteit $(31,32)$ alsmede aan een breed opleidend HBO (41, verder aan te duiden als breed HBO) meer prioriteit toe dan mensen met een reputatie. 
Alleen interne flexibiliteit (wederom gedichotomiseerd in $50 \%$ lage en $50 \%$ hoge scores) laat een relevant verband met (de door informanten genoten) opleiding zien, zoals blijkt uit de onderstaande tabel:

Tabel 33: INTERNE FLEXIBUITETT VAN HET HBO ALS STRUCTUURKENMERK GESPECIFICEERD NAAR OPLEIDING (V3) (Percentages tussen hatajes)

\begin{tabular}{lcclc}
\hline $\begin{array}{l}\text { Interne } \\
\text { flexibiliteit } \\
\text { CONC 31 }\end{array}$ & $\begin{array}{l}\text { Opleiding (V3) } \\
\text { Soc.-pedag. }\end{array}$ & Econ.-Admin. & Technisch & Totaal \\
\hline $50 \%$ Laag & $65(42)$ & $63(53)$ & $37(63)$ & $165(50)$ \\
$50 \%$ Hoog & $89(58)$ & $57(47)$ & $22(37)$ & $168(50)$ \\
\hline Totaal & $154(100)$ & $120(100)$ & $59(100)$ & $333(100)$ \\
\hline
\end{tabular}

Chi-kwadraat $=7.8(\mathrm{p}<.05)$

Cramer's $\mathrm{V}=.15$

Het berekende verband is relevant (Cramer's $\mathrm{V}=.15$ ) en komt tot stand doordat mensen met een sociaal-pedagogische opleiding het aspect interne flexibiliteit (kleinschaliger; individueler HBO) meer benadrukken dan mensen met een economisch-administratieve of technische opleiding (resp. 58, 47 en $37 \%$ ).

Het verband tussen opleiding en de wenselijkheid toegekend aan interne flexibiliteit is aanwezig binnen de groep zonder reputatie: dit verband ontbreekt daarentegen in de groep met reputatie. Het zijn met name de sociaal-pedagogisch opgeleiden zonder reputatie die de interne flexibiliteit benadrukken (61 $\%)$. De "overige opgeleiden" zonder reputatie zijn daar minder woor te vinden $(44 \%)$. Het vastgestelde verband is evenwel niet sterk ( $\mathrm{Phi}=.16$ ).

Vergelijking van de scores van informanten uit de sectoren arbeid en onderwijs (binnen de twee reputatie-groepen) laat zien dat er geen verband bestaat tussen positie en interne flexibiliteit. Een identieke conclusie trekken wij uit de partiële tabellen met opleiding en interne flexibiliteit onder controle van de positie: ook hier zijn geen significante verbanden aangetoond.

Het domein structuur kunnen wij als volgt samenvattend typeren. Over het geheel genomen wordt aan de aspecten interne en externe flexibiliteit, breed en specifiek opleidend HBO geen hoge prioriteit toegekend. Zij staan wat dat betreft onderaan (zie tabel 28). De reputatie die actores genieten blijkt samenhang te vertonen met de verschillen in scores op interne flexibiliteit, externe flexibiliteit (de flexibele relatie met de beroepspraktijk) en breed opleidend HBO: (d.w.z. een HBO dat een algemeen vormende voorbereiding biedt op maatschappelijke taken). Verdeling van de scores (in 50 procent laagste en 50 procent hoogste scores, ten einde deze reputatie-groepen nader te kunnen identificeren) laat zien dat voor de groep zonder reputatie een onderscheid 
moet worden gemaakt naar opleiding. De aard van de opleiding speelt geen rol in de groep met reputatie. Positie - d.w.z. de vraag waar men werkt blijkt binnen beide "reputatie"-groepen geen discriminerende variabele te zijn. Binnen het domein structuur en organisatie werden de vier onderscheiden concepten - over het algemeen genomen - laag geprefereerd. Ze lieten weinig relevante associaties zien met sociale achtergrondkenmerken.

\subsection{CONCLUSIES}

Er zijn dertien schalen gebruikt om visies in kaart te brengen. Dit is gedaan middels de vergelijking van de somscores (volgens het additieve schaalmodel van Likert). Analyse toont aan dat er op een aantal schalen relevante verschillen in gemiddelden zijn tussen de verschillende categorieën van respondentkenmerken (zie tabel 29). De schalen zijn vervolgens per domein (zoals in de hoofdstukken $3 \mathrm{t} / \mathrm{m} 5$ beschreven) aan de orde gekomen en de meest relevante verschillen zijn beschreven.

Van de zes kwaliteitsaspecten blijken "organisatie en planning" en "management ondersteumende technieken" samen te hangen met positie en/of betrokkenheid bij de beleidsontwikkeling. Organisatie en planning als kwaliteitseis wordt vooral benadrukt door informanten uit het onderwijs en daarbinnen vooral door mensen, die actief participeren in de beleidsontwikkeling. Managementtechnicken worden vooral benadrukt door informanten uit de sector arbeid die aan beleidsontwikkeling bijdragen.

Van de drie interactie-aspecten blijkt afhankelijkheid wan het $\mathrm{HBO}$ ten opzichte van de beroepspraktijk een punt te zijn dat de meningen doet divergeren. Het zijn mensen met een reputatie op het gebied van de relatie HBO en beroepspraktijk die van mening verschillen: onderwijsmensen żijn minder geporteerd voor een afhankelijk HBO dan informanten uit de sector arbeid. Zowel onderwijs- als arbeidsmensen zijn het eens over de autonomie van het HBO: volstrekte autonomie is minder gewenst.

Aan de structuur-aspecten wordt over het geheel genomen geen hoge prioriteit toegekend. Ook hier is reputatie een belangrijk onderscheidingscriterium. Maar nu omgekeerd: mensen met een reputatie zijn het eens over de wenselijkheid van interne flexibiliteit, i.t.t. mensen die deze reputatie niet hebben. Binnen de laatstgenoemde groep blijkt de opleiding een rol te spelen: mensen met een sociaal-pedagogische achtergrond benadrukken de interne flexibiliteit meer dan mensen met een andere opleiding.

Het veertiende concept; "de regelgeving", is - zoals in hoofdstuk 7 reeds werd aangegeven - verder buiten beschouwing gelaten omdat het geen relevante samenhang te zien geeft met de overige dertien concepten. 


\section{Conclusies en perspectieven}

\subsection{INLEIDING}

In dit hoofdstuk wordt allereerst een overzicht gepresenteerd van het theoretisch traject van het onderzoek (paragraaf 9.2). Vervolgens worden de voornaamsite conclusies getrokken rond de aspecten steekproeftrekking, dataverzameling en validiteit van het empirisch deel van het onderzoek (paragraaf 9.3).

Paragraaf 9.4 gaat in op conclusies met betrekking tot de aangetroffen dimensionaliteit. Paragraaf 9.5 handelt over de prioritering van de hoofdcomponenten. De visies op de oorspronkelijke kernelementen "kwaliteit-interactie-structuur" vormen paragraaf 9.6. Ten aanzien van de expertness van de geraadpleegde informanten wordt concluderend gerapporteerd in paragraaf 9.7. Het hoofdstuk vervolgt met een correspondentie-analyse en een grafische weergave van de daarbij geconstateerde samenhangen tussen kenmerken én visies van respondenten (paragraaf 9.8).

De perspectieven die er zijn voor het werken in concreto aan de verhouding van onderwijs en arbeid en enkele suggesties voor - methodische - follow up van deze studie, worden geschetst in paragraaf 9.9 .

\subsection{RESUME VAN HET THEORETISCHE DEEL}

Tegen de achtergrond van een beschrijving van de maatschappelijke functies van het Hoger Beroepsonderwijs en een schets van de wijzen waarop de relatie van onderwijs en arbeid kan worden beoordeeld, hebben wij visies op de relatie van het Hoger Beroepsonderwijs en de beroepspraktijk in kaart gebracht. Daarin is het onderwerp eerst nader gespecificeerd naar drie gezichtspunten: de kwaliteit van de $\mathrm{HBO}$-opbrengst, de aard van de interactie en de gewenste ontwikkeling van het $\mathrm{HBO}$ met betrekking tot zijn structuur en organisatie. Deze thema's blijken in discussies en publikaties over de spanningsmomenten in de relatie van het $\mathrm{HBO}$ en beroepspraktijk, de rode draad te vormen.

Vervolgens zijn deze aspecten theoretisch uitgewerkt. Wij stelden vast dat in de diverse benaderingen van het kwalificatiebegrip steeds de relatie/interactie 
van $\mathrm{HBO}$ en beroepspraktijk aan de orde is. Uitgaande van de tweedeling tussen technisch-instrumentele en sociaal-normatieve kwalificaties, hebben wij in het onderdeel "toekomstige kwaliteit" veertien elementen verder ontleed in een aantal aspecten. Het thema "interactie"' is besproken vanuit een aantal visies op kenmerken van de relatie tussen het $\mathrm{HBO}$ en de beroepspraktijk. Pro- of re-activiteit en de mate van professionalisatie en de heterogeniteit zijn daarbij aan de orde gekomen. De toekomstige ontwikkeling van het $\mathrm{HBO}$ qua "structuur en organisatie" is besproken vanuit de diverse visies over toekomsttrends die daaromtrent in de literatuur te vinden zijn. Over dit deel zijn negen aspecten nader gespecificeerd en voorgelegd aan de informanten.

Over de vraag hoe de verhouding van onderwijspraktijk en beroepspraktijk er in de toekomst uit zou moeten zien, lopen de meningen uiteen, gelet op de in het theoretische deel van deze studie beschreven spanningsmomenten tussen onderwijs en arbeid. Gezien de variëteit die de respondentengroep qua scores aan de dag legt, luidt de (algemene) conclusie dat de meningen inderdaad verdeeld zijn. Visies op de verhouding van twee in ontwikkeling zijnde maatschappelijke grootheden als onderwijs en arbeid zijn, lijken effectbeladen.

In de discussies erover, frapperen zowel de lange duur, en het cliché-matige karakter van oor-en vooroordelen. Om het taalveld te verduidelijken werd een onderzoeksdesign ontworpen om in kaart te brengen wat er aan visies en verwachtingen bij relevante actores leefde. De informantengroep werd samengesteld middels een vooronderzoek.

\subsection{CONCLUSIES MET BETREKKING TOT DE DATAVERZAMELING IN VOOR- ONDERZOEK EN SURVEYONDERZOEK}

\section{Vragenlijst en steekproef}

Via een voorgecodeerde vragenlijst zijn de items voorgelegd aan een steekproef van relevante actores in Limburg. Een relevante actor is iemand die aan minimaal een van de twee voorwaarden voldoet: de persoon moest op grond van zijn/haar taakstelling te maken hebben met het HBO (de positie) en/of de persoon in kwestie moest een bepaalde deskundigheid genieten op het gebied van de aansluitingsproblematiek van het $\mathrm{HBO}$ en de beroepspraktijk (de reputatie). De reputatie is vastgesteld middels toepassing van de reputatiemethode uit de sociaal-netwerkanalyse.

Wij concludeerden reeds tot het feit dat de reputatie, toegekend in het uitgevoerde vooronderzoek, niet noemenswaard veranderde door scores - ach- 
teraf toegekend - in het survey-onderzoek. Een nadeel van de toepassing der reputatie-methode zou in dit geval mogen heten dat de informantengroep voor een groot deel uit experts bestond die op grond van de opgedane ervaring en de mate van betrokkenheid kunnen neigen naar dezelfde visies.

\section{De respons}

De respons op het survey-onderzoek bedroeg $73 \%$. Het onderwerp was voor respondenten kennelijk relevant genoeg hun medewerking te verlenen. Hierbij moet worden aangetekend dat men in veel gevallen (op grond van het vooronderzoek) op de hoogte was van het onderzoek en zijn medewerking had toegezegd.

Meer dan $95 \%$ van de informanten was in toezending van een samenvatting geïnteresseerd. Dit gegeven, gevoegd bij het hoge responspercentage, geeft grond aan de stelling dat het thema de toekomstige verhouding van onderwijspraktijk en beroepspraktijk, de geraadpleegde experts kennelijk aanspreekt.

\section{De informantengroep}

De informantengroep (gevormd door het gecombineerde gebruik van de positieen de reputatiemethode) kan als een representatieve afspiegeling worden beschouwd van de populatie "experts inzake de aansluiting van HBO en beroepspraktijk in het geografisch domein van het onderzoek, i.c. de provincie Limburg". De kenmerken waarvan de verdeling in de steekproef (het aantal uitgezette enquêtes) vooraf bekend is, zijn de spreiding over de drie sectoren (arbeid, onderwijs en intermediair), de verdeling van de aard van de arbeidsorganisaties en de verdeling van de ingraad.

Wij stelden vast dat de respons een goede afspiegeling was van de steekproef. De antwoordbereidheid van mensen uit de sector arbeid is hoger dan die van mensen uit de sector onderwijs (resp. $78 \%$ en $60 \%$ ). Niettemin ontlopen de verdelingen in de steekproef en de respons elkaar niet veel: in de respons is de proportie mensen uit de sector arbeid hoger dan in de steekproef (resp. $68 \%$ en $63 \%$ ). Het omgekeerde beeld geldt voor de mensen uit de onderwijssector, terwijl de mensen uit de intermediaire in beide verdelingen in gelijke proporties vertegenwoordigd zijn.

Die grotere antwoordbereidheid komt vooral op rekening van de mensen uit de industriële bedrijfstakken en de kwartaire sector (respons resp. 95\% en $82 \%$ ). Mensen afkomstig uit de dienstensector zijn in deze iets terug-houden- 
wordt beschouwd. Een score van 100 komt overeen met een minimale, 500 met een maximale wenselijkheid.

Er zijn twee aspecten van deze schaalconstructie die aandacht verdienen: het probleem van ontbrekende scores (de zg. "missing values") en de betrouwbaarheid van de schaal. Voor de ontbrekende antwoorden van een respondent op een of meer variabelen is een veel gebruikte schattingsprocedure gebruikt. Als een respondent op minder dan de helft minus $1\left(1 / 2^{*}(\mathrm{P}-1)\right)$ van het aantal variabelen (P) uit een schaal geen antwoord heeft gegeven, dan nemen we aan dat de persoon in kwestie het patroon wan de wel gegeven antwoorden volgt. In alle andere gevallen beschouwen we de schaalscore als ontbrekend. Het aantal ontbrekende gegevens blijkt relatief laag te zijn (maximaal 3,8\%). De betrouwbaarheid van de gevonden schalen wordt uitgedrukt in de $\mathrm{zg}$. Cronbach's alpha betrouwbaarheidscoëfficiënt. De essentie van de procedure is het opsplitsen van de gegevens in gelijke parallelle delen, het apart meten van die delen en het vervolgens bepalen in hoeverre de resultaten van die metingen overeenkomen (vgl Swanborn, 1982). In bijlage IV zijn deze betrouwbaarheidscoscoscoëfficiënten per schaal weergegeven. Vijf van de dertien schalen hebben een betrouwbaarheid van minder dan .70. Dat is minder dan de gangbare normen voorschrijven (vgl Nunnally, 1978, p. 162).

De prioriteit van de concepten als kernaspecten die in de relatie $\mathrm{HBO}$ en beroepspraktijk het meest gewenst worden, is af te leiden uit de hoogte van de gemiddelde scores op de concepten. Het meest gewenste aspect heeft het hoogste gemiddelde.

De relatief hoge gemiddelden (groter dan 400) wijzen erop dat zelfstandigheid, het kunnen organiseren van het eigen werk en het bezit van communicatieve vaardigheden van de HBO-er als meest wenselijke eigenschappen worden gezien (respectieve gemiddelden 426, 410 en 432). Nog sterker valt de nadruk op de aard van de interactie (460). Minder wenselijk, maar zeker niet ongewenst, zijn de interne en externe flexibiliteit van het $\mathrm{HBO}$, breed HBOonderwijs en specifiek HBO-onderwijs.

Opmerkelijk is verder dat de instemming met "Autonoom $\mathrm{HBO}^{\text {" het laagst }}$ scoort (165). Kennelijk is men over het algemeen minder geporteerd voor dit idee. Tabel 28 op de volgende bladzijden, geeft een inzicht in de scores op en de rangorde van de concepten, opgevat als additieve schalen, zoals boven omschreven. 
Tabel 28: Essentie, gemiddelde score (X), standaardafwijking (S), aantal (N) en Cronbachs alpha (a) wan de schalen, gepresenteerd in de reeks meest-minst geprefereerd

\begin{tabular}{|c|c|c|c|c|c|c|c|}
\hline schaal/concept: & $\begin{array}{l}\text { concept- } \\
\text { no }\end{array}$ & domein & essentie & $x$ & $S$ & $\mathbf{N}$ & a \\
\hline $\begin{array}{l}\text { Aard van de } \\
\text { interactie }\end{array}$ & 22 & $\begin{array}{l}\text { Inter- } \\
\text { actie }\end{array}$ & $\begin{array}{l}\text { HBO volgt ontwikkelingen } \\
\text { in beroepspraktijk/is } \\
\text { bereid tot open dialoog }\end{array}$ & 460 & 56 & 361 & .61 \\
\hline $\begin{array}{l}\text { Comm. valardig- } \\
\text { heden }\end{array}$ & 12 & $\begin{array}{l}\text { Kwali- } \\
\text { teit }\end{array}$ & $\begin{array}{l}\text { Schriftelijke/mondelinge } \\
\text { uitdrukkingswardigheden } \\
\text { en rapportagetechnick }\end{array}$ & 432 & 64 & 355 & .76 \\
\hline $\begin{array}{l}\text { Zelfstandig- } \\
\text { hei }\end{array}$ & 11 & $\begin{array}{l}\text { Kwali- } \\
\text { teit }\end{array}$ & $\begin{array}{l}\text { Ideeën ontwikkelen/ } \\
\text { initiatieven nemen, } \\
\text { keuzen doen }\end{array}$ & 426 & 59 & 354 & .81 \\
\hline $\begin{array}{l}\text { Organisatie en } \\
\text { planning }\end{array}$ & 14 & $\begin{array}{l}\text { Kwali- } \\
\text { teit }\end{array}$ & $\begin{array}{l}\text { Organiseren van eigen } \\
\text { werk en van werk van } \\
\text { anderen/samenwerking } \\
\text { collegae }\end{array}$ & 410 & 65 & 355 & .78 \\
\hline Samenwerking & 13 & $\begin{array}{l}\text { Kwali- } \\
\text { teit }\end{array}$ & $\begin{array}{l}\text { Samenwerking met exter- } \\
\text { ne vrijwilligers/supe- } \\
\text { rieuren partijen/ }\end{array}$ & 375 & 78 & 354 & .75 \\
\hline Leiding geven & 51 & $\begin{array}{l}\text { Kwali- } \\
\text { teit }\end{array}$ & $\begin{array}{l}\text { Organisatiegebonden } \\
\text { taken/beleidsontwikkeling }\end{array}$ & 372 & 71 & 351 & .77 \\
\hline $\begin{array}{l}\text { Managementtech- } \\
\text { nieken }\end{array}$ & 52 & $\begin{array}{l}\text { Kwali- } \\
\text { teit }\end{array}$ & $\begin{array}{l}\text { Technieken woor onder- } \\
\text { zoek/marketing en bud- } \\
\text { getbewaking }\end{array}$ & 352 & 79 & 348 & .77 \\
\hline Afhankelijjk & 23 & $\begin{array}{l}\text { Inter- } \\
\text { actie }\end{array}$ & $\begin{array}{l}\text { HBO is afhankelijk van } \\
\text { ontwikkelingen in de } \\
\text { beroepspraktijk en moet } \\
\text { daardoor worden bepaald }\end{array}$ & 349 & 84 & 362 & .63 \\
\hline $\begin{array}{l}\text { Externe flexil- } \\
\text { biliteit }\end{array}$ & 32 & $\begin{array}{l}\text { Struc- } \\
\text { tuur en } \\
\text { organi- } \\
\text { satie }\end{array}$ & $\begin{array}{l}\text { HBO in beroepspraktijk } \\
\text { integreren/meer stages/ } \\
\text { leerlingstelsel- } \\
\text { concept overwegen }\end{array}$ & 338 & 88 & 356 & .70 \\
\hline Breed $\mathrm{HBO}$ & 41 & $\begin{array}{l}\text { Struc- } \\
\text { tuur en } \\
\text { organi- } \\
\text { satie }\end{array}$ & $\begin{array}{l}\text { Brede opleiding/algemeen } \\
\text { vormend/algemene kwalifi- } \\
\text { caties }\end{array}$ & 301 & 82 & 358 & .75 \\
\hline $\begin{array}{l}\text { Interne flexi- } \\
\text { biliteit }\end{array}$ & 31 & $\begin{array}{l}\text { Struc- } \\
\text { tuur en } \\
\text { organi- } \\
\text { satie }\end{array}$ & $\begin{array}{l}\text { HBO in kleine eenheden/ } \\
\text { gedecentraliseerd/ } \\
\text { geindividualiseerd aan- } \\
\text { bieden en organiseren }\end{array}$ & 273 & 69 & 354 & .68 \\
\hline
\end{tabular}


Vervolg tabel 28: Essentie, gemiddelde score $(X)$, standaardafwijking ( $S$ ), aantal $(N)$ en cronbachs alpha (a) van de schalen, gepresenteero in de reeks meesi-minst geprefereerd

\begin{tabular}{llllllll}
\hline schaal/concept: concept- domein & essentie & $X$ & S & N & al \\
no & 42 & $\begin{array}{l}\text { Struc- } \\
\text { tuur en } \\
\text { organi- } \\
\text { satie }\end{array}$ & $\begin{array}{l}\text { Specifiek functiegericht } \\
\text { opleidend HBO }\end{array}$ & 263 & 92 & 350 & .63 \\
\hline Autonoom HBO 21 & $\begin{array}{l}\text { Inter- } \\
\text { actie }\end{array}$ & $\begin{array}{l}\text { HBO als autonoon insti- } \\
\text { tuut dat zelf beroeps- } \\
\text { praktijkeisen bepalt/ } \\
\text { verschil in sfeer met } \\
\text { beroepsprakrijk }\end{array}$ & 72 & 362 & .65 \\
\hline
\end{tabular}

De gemiddelden geven de toegekende mate van wenselijkheid aan. De alpha's verwijzen naar de betrouwbaarheid en de standaardafwijkingen zijn een maat voor de spreiding. De gemiddelden kunnen op verschillende manieren tot stand komen; enkele uitschieters bijvoorbeeld kunnen voor vertekening zorgen. Ook kan de frequentieverdeling meertoppig zijn. Inspectie van de frequentieverdelingen laat zien dat de geniddelden niet vertekend zijn, noch door dergelijke uitschieters, noch door meertoppigheid.

\subsection{DE EERSTE RESULTATEN VAN HET ONDERZOEK NAAR VERSCHILLEN IN VISIES}

In tabel 29 hebben wij het resultaat van de analyses samengevat. Enkele punten vallen daarbij op. Ten eerste blijkt dat de rangordening van de concepten, zoals die eerder is vastgesteld, niets zegt over het verschil in denken over een bepaald concept binnen bepaalde subgroepen. Wij komen hierop in dit hoofdstuk terug. Ten tweede lijken ten aanzien van een aantal kwesties de meningen minder te divergeren dan verwacht: Een aantal concepten laat geen relevante associaties zien. Het gaat hierbij om:

concept 12 = communicatieve vaardigheden (uitdrukkingsvaardigheid in woord en geschrift)

concept 21 = autonoom HBO (HBO als instituut dat zelf eisen bepaalt) concept 22 = de aard van de interactie (actief omgevingsgericht $\mathrm{HBO}$ ) concept 42 = specifiek opleidend HBO (specifiek functiegerichte opleiding) concept 51 = leidinggeven (ontwikkelen van visies, beleid; leiden van mensen)

Het zijn vooral de concepten verbandhoudend met interactie (de relatie van onderwijs- en beroepspraktijk) die geen relevante verbanden opleveren en - merkwaardig genoeg - zorgen voor de minste divergenties in visies. Merkwaardig, omdat in de literatuur het beeld opdoemt van een gecompliceerde 
verhouding en tal van momenten wan spanning in de relatie van onderwijsen beroepspraktijk. Essentieel is dat de autonomie van het HBO (21) en de aard van de interactie (22) geen verschillen qua visies laten zien.

Specifiek opleidend HBO (42) (overigens al eerder als relatief laag geprefereerd aspect opgevallen (zie tabel 28)) laat geen enkele relevante associatie met achtergrondkenmerken zien evenals het aspect communicatieve vaardigheden (12) en leidinggeven (51). Vervolgens blijkt dat een aantal sociale achtergrondkenmerken geen rol van betekenis speelt. De vraag naar gelijkheid van opleiding en werk (V4) bijwoorbeeld, was bedoeld om na te gaan of degenen die de aansluiting van opleiding en werk "aan den lijve" hadden ondervonden anders zouden denken dan degenen die vanuit de opleiding in het aansluitende beroepenveld doorstroomden. Dat kenmerk en de duur van werkzaamheid (zowel V5 en V6) blijken geen rol te spelen.

Overzien wij het geheel, dan blijken met name de soort van de genoten opleiding (V3), de positie (V7), de betrokkenheid bij discussies en beleidsontwikkeling (resp. V10 en V11) alsmede de reputatie (ID) meer te kunnen zeggen over de verschillen tussen diverse groepen.

Het volgende overzicht geeft een beeld van relevante samenhangen tussen kenmerken van respondenten en scores van bepaalde subpopulaties op beoordelingsdimensies. Niet-significante en niet-relevante samenhangen zijn daarin niet opgenomen. In tabel 29 zijn de betrokkenheidsvariabelen (V10 en V11) gedichotomiseerd, waarbij de categorieën 1,2 en 3 als "niet of nauwelijks betrokken" worden beschouwd en de categorieën 4 en 5 als "wel betrokken".

In de volgende paragrafen worden de kwaliteits- en interactie-aspecten besproken. In paragraaf 8.6 komen de structuur- en organisatie-aspecten aan de orde. In paragraaf 8.7 vatten wij de resultaten kort samen. 
Tabel 29. Gemiddelden $(X 100)$ voor beoordelingsdimensies gespecificeerdt stadr sociaal-structurele achtergrondkenmerken (alleen relevante samenhangen zijn vermetd/eta: .15)

\begin{tabular}{|c|c|c|c|c|c|c|c|c|}
\hline \multirow{2}{*}{$\begin{array}{l}\text { Sociale structurele } \\
\text { kenmerken }\end{array}$} & \multirow[b]{2}{*}{11} & \multirow[b]{2}{*}{13} & \multirow[b]{2}{*}{14} & \multicolumn{3}{|c|}{ Schaalnummer } & \multirow[b]{2}{*}{41} & \multirow[b]{2}{*}{52} \\
\hline & & & & 23 & 31 & 32 & & \\
\hline \multicolumn{9}{|l|}{ OPLEIDING $(V 3)$} \\
\hline Social-pedagogische opleiding & & 385 & & 334 & 285 & & & \\
\hline Economisch/admin.opleiding & & 360 & & 353 & 268 & & & \\
\hline Technische opleiding & & 365 & & 382 & 256 & & & \\
\hline \multicolumn{9}{|l|}{ POSITTE (V7) } \\
\hline Arbeid & 420 & 365 & 424 & 355 & 266 & & & \\
\hline Onderwijs & 433 & 397 & 458 & 317 & 283 & & & \\
\hline Intermediair & 446 & 394 & 433 & 375 & 302 & & & \\
\hline \multicolumn{9}{|l|}{ INGRAAD-INDEX (ID) } \\
\hline Niek genoemd & & & & & 287 & 358 & 314 & \\
\hline Eenmaall genoemd & & & & & 256 & 318 & 286 & \\
\hline Meer dan eenmaal genoemd & & & & & 270 & 329 & 296 & \\
\hline \multicolumn{9}{|l|}{ BESLISSENDE INVLOED (V9) } \\
\hline Niet of nauwelijks betrokken & & 371 & & & & & & \\
\hline Wel betrokken & & 405 & & & & & & \\
\hline \multicolumn{9}{|l|}{ BETROKKENHEID BU } \\
\hline \multicolumn{9}{|l|}{ DISCUSSIE (V10) } \\
\hline Niet of nauwelijks betrokken & & & 425 & & & & & \\
\hline Wel betrokken & & & 446 & & & & & \\
\hline \multicolumn{9}{|l|}{ BETROKKENHEID BELEIDS- } \\
\hline Niet of nauwelijks betrokken & & 369 & 428 & & & & & 346 \\
\hline Wel betrokken & & 416 & 456 & & & & & 390 \\
\hline \multicolumn{9}{|l|}{$\begin{array}{l}\text { Schaalgemiddelden voor de } \\
\text { gehele onderzoekspopulatie }\end{array}$} \\
\hline (zie tabell 28): & 426 & 375 & 432 & 349 & 273 & 338 & 301 & 352 \\
\hline Standaardafxijjking & 59 & 78 & 64 & 84 & 69 & 88 & 82 & 79 \\
\hline
\end{tabular}

Legenda schaalmummers:
11: zelfstandigheid
31: interne flexibiliteit
13: samenwerking
32: externe flexibiliteit
14: organisatie en planning
41: breed opleidend HBO
23: afhankelijk HBO
52: managenenttechnieken

\subsection{PRIORITEITEN BINNEN HET DOMEIN KWALITEIT}

Tabel 29 laat zien dat van de zes oorspronkelijke kwaliteitsaspecten drie aspecten verschillend worden beoordeeld door de informanten uit de arbeidssector, het onderwijs en de intermediaire organisaties. Zelfstandigheid (concept 11) als aspect waarop het toekomstig HBO bij de beroepswoorbereiding vooral zou moeten letten, wordt hoog aangeslagen door de intermediaire sector en 
het minst door de arbeidssector, terwijl het onderwijs het midden houdt (respectievelijke gemiddelden 446,420 en 433).

Samenwerking (concept 13, opgevat als in- en extern samenwerken, omgaan met mensen binnen en buiten de werkorganisatie) wordt daarentegen vooral benadrukt door het onderwijs en de intermediaire sector, terwijl de arbeidssector daar minder wenselijkheid aan toekent (resp. 397, 394 en 365). Organisatie en planning (concept 14, opgevat als de vaardigheid eigen en andermans werk te organiseren en samen te werken met collegae) worden het meest wenselijk geacht door de sector onderwijs (gemiddelde 458), terwijl de intermediaireen de arbeidssector daar min of meer hetzelfde over denken (resp. 433 en 424). Opvallend bij deze drie aspecten is dat het telkenmale de arbeidssector is die het meest terughoudend scoort qua toegekende wenselijkheden.

We kunnen zien dat er relevante verbanden zijn tussen visies op "organisatie en planning" (14) en positie (V7) alsmede visies op "management ondersteunende technieken" (52) en betrokkenheid bij belleidsontwikkeling (V11). Verwezen wordt naar tabel $30 \mathrm{~A}$ en $30 \mathrm{~B}$.

Tabel 3QA: ORGANISATIE EN PLANNING (CONCEPT 14) ALS KWALTTETTSKENMERK GESPECIFICEERD NAAR POSITIE (VT) (Percentages tussen haakjes)

\begin{tabular}{lllll}
\hline Positie $(V 7)$ & & & \\
CONC 14 & Arbeid & Onderwijs & Intermediair & Totaal \\
\hline $50 \%$ Laag & $150(63)$ & $28(38)$ & $21(53)$ & $199(57)$ \\
$50 \%$ Hoog & $89(37)$ & $45(62)$ & $19(47)$ & $153(43)$ \\
\hline Totaal & $239(100)$ & $73(100)$ & $40(100)$ & $352(100)$ \\
\hline
\end{tabular}

Chi-kwadraat $=13.8(p<.05)$

Cramer's $\mathrm{V}=.19$

Tabel 3OB: MANAGEMENT-ONDERSTEUNENDE TECHNIEKEN (CONCEPT 52) ALS KIWALITEITSKENMERK GESPECIFICEERD NAAR BELEIDSBETROKKENHEID (V11) (Percentages tassen haakjes)

Betrokken bij beleid (V11)

\begin{tabular}{llll} 
CONC 52 & Niet & Well & Totaal \\
\hline $50 \%$ Laag & $117(61)$ & $18(35)$ & $195(57)$ \\
$50 \%$ Hoog & $114(39)$ & $33(65)$ & $147(43)$ \\
\hline Totaal & $291(100)$ & $51(100)$ & $342(100)$ \\
\hline
\end{tabular}

Chi-kwadraat $=10.5(p<.05)$

Cramer"s $\mathrm{V}=.17$ 
Organisatie en planning als kwaliteitsaspecten worden door informanten uit de sector onderwijs wenselijker geacht dan door mensen uit de sector arbeid (63\% vs $37 \%$ ), terwijl de informanten uit de intermediaire organisatie daarover kennelijk niet zo verschillend denken.

Binnen de categorieën van betrokkenheid bij beleid blijkt het verband tussen positie en organisatie/planning alleen te bestaan binnen de groep die zich wel betrokken acht: het zijn voornamelijk de actief in het beleid participerende onderwijsmensen die meer madruk leggen op organisatie/ planning. De actief participerenden uit de sector arbeid denken daar niet zo eensluidend over (onderwijs $71 \%$ en arbeid $41 \%$ ). Zie tabel 31.

Tabel 31: ORGANISATIE EN PLANNING (CONCEPT 14) ALS KWALITEITSKENMERK GESPECIFICEERD NAAR DE SECTOREN ARBEID EN ONDERWIJS EN BELEIDSBETROKKENHEID (V11) (Percentages tussen haakjes)

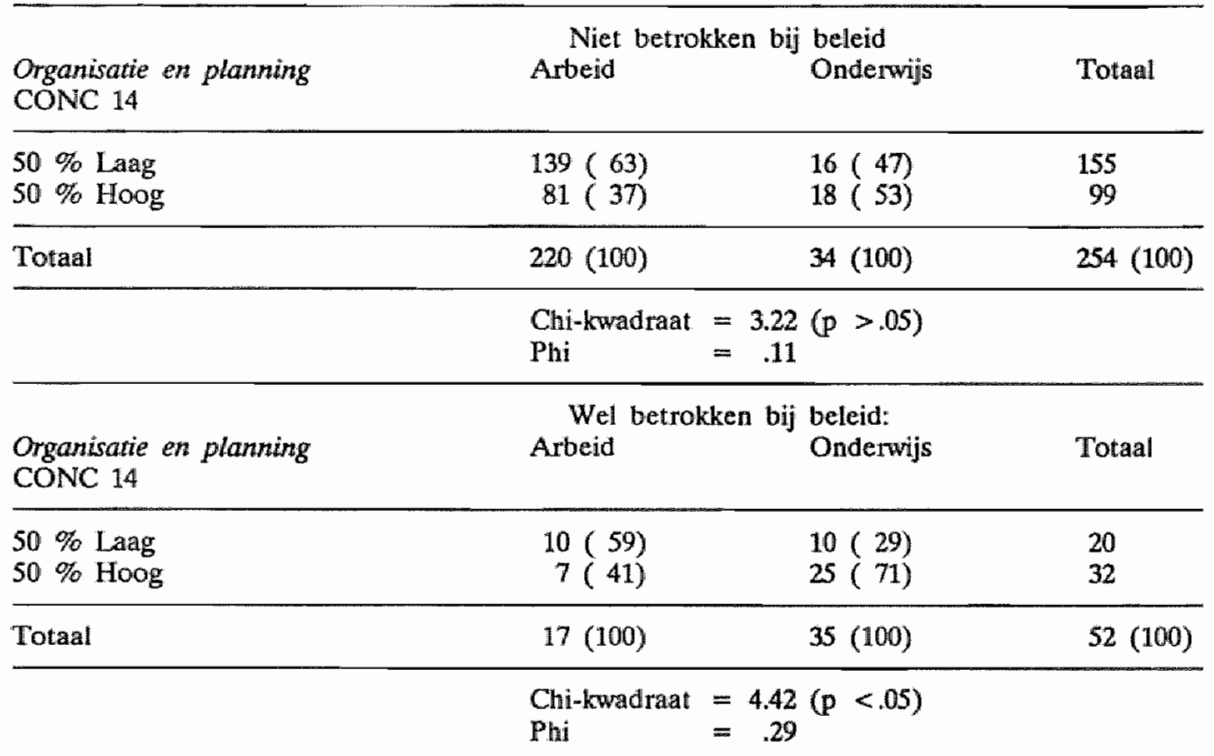

Ervan uitgaande dat betrokkenheid bij het beleid impliceert dat men ook aan discussies deelneemt, moet een identiek verband als bovenbeschreven onder de condities van discussie-betrokkenheid (V10) te vinden zijn. Dit bleek inderdaad het geval te zijn (Phi $=.23$ ). We kunnen deze lijn doortrekken naar het aspect reputatie. Betrokkenheid bij discussies of beleid houdt in dat er een bepaalde "zichtbaarheid" bestaat, dat will zeggen de reputatie is mede afhankelijk van de mate waarin men in allerlei groepen en fora participeert. Wij hebben de ingraad (ID) gedichotomiseerd, waarbij niet of slechts eenmaal genoemd geldt als "geen reputatie". Ook hier bleek een sterk verband te 
bestaan tussen positie en organisatie/ planning binnen de groep met een reputatie (Cramer's $\mathrm{V}=.29$ ).

Als wij visies specificeren volgens de door informanten genoten opleiding, dan kunnen wij om technische redenen alleen de onderwijssector vergelijken met de arbeidssector. Gelet op de geringe aantallen respondenten in deze subcategorieen, kon door te lage aantallen in de oorspronkelijke cellen geen betekenisvolle analyse worden doorgevoerd. Daarbij blijkt opleiding geen rol van betekenis te spelen op de verdeling over de sectoren. De partiële tabellen van positie en organisatie/planning onder constanthouding van opleiding vertonen nagenoeg dezelfde samenhang als de oorspronkelijke tabel.

Identieke analysestappen zijn gezet met betrekking tot het aspect "management ondersteunende technieken" (verder af te korten als "management"). Dit concept impliceert fondswerving, budgetbeheer, research en marketing. Visies op dit aspect hangen samen met de betrokkenheid bij beleidsontwikkeling. Dit verband verdwijnt binnen de sector onderwijs, maar blijft binnen de sector arbeid $(\mathrm{Phi}=.18)$. Dit betekent dat betrokkenheid bij beleidsontwikkeling binnen onderwijs geen rol speelt. Anders ligt dit bij de arbeidssector: de actief participerenden leggen meer nadruk op managementtechniek dan de niet-participerenden ( $64 \%$ vs. $36 \%$ ).

Betrokkenheid bij beleidsontwikkeling speelt geen rol bij mensen met een economisch-administratieve of technische opleiding; daarentegen differentieert het beeld wel binnen de groep sociaal-pedagogisch opgeleiden. Het betrokken zijn in beleidsontwikkeling leidt tot een grotere nadruk op managementtechniek als kwaliteitseis, dan het niet betrokken zijn ( $75 \%$ ws $38 \%$, Phi $=.29$ ).

Samenvattend: van de zes aspecten met betrekking tot kwaliteit blijken "organisatie/planning" en "managementtechnieken"' verschillen op te leveren die samenhangen met positie en betrokkenheid bij beleidsontwikkeling. Het aspect organisatie/planning blijkt vooral benadrukt te worden door onderwijsmensen die zelf actief participeren in beleidsontwikkeling.

Dit is een beeld dat bevestigd wordt als wij letten op de toegekende reputatie: ook hier zijn het onderwijsmensen met een reputatie die organisatie/planning als een gewenste eigenschap van de HBO-er vooral benadrukken. Managementtechnieken als gewenst aandachtspunt in de beroepswoorbereiding door het HBO wordt vooral door mensen uit de arbeidsector geprefereerd en daarbinnen vooral door hen die actief bezig zijn met beleidsontwikkeling. Het dimensionaliseringsonderzoek bracht al aan het licht dat de denkkaders van - onder andere - subgroepen uit de sectoren arbeid en onderwijs dezelfde 
zijn. Bezien wij de zes kwaliteitsaspecten (concepten opgevat als schalen) dan valt op dat het vooral de "sociaal normatieve" aspecten van het kwaliteitsdomein zijn die zowel hoog geprefereerd worden (vgl tabel 29) alsook de meeste - relevante - associaties met sociale achtergrondkenmerken laten zien. In hoofdstuk 9 komen wij op de conclusies terzake nog terug.

\subsection{PRIORITETEN BINNEN HET DOMEIN INTERACTIE}

Binnen dit probleemveld wordt door de informanten duidelijk verschillend gedacht over de richting waarin afhankelijkheid van bet HBO ten opzichte van de beroepspraktijk moet gaan. De autonomie van het $\mathrm{HBO}$ is merkwaardig genoeg geen punt dat visies sterk doet divergeren, evenmin als de gewenste aard van de interactie. Een autonoom HBO (waarbij de sfeer van HBO en beroepspraktijk duidelijk verschillend is en het $\mathrm{HBO}$ de markteisen bepaalt) wordt niet gewenst. Een attent volgend $\mathrm{HBO}$, in een actieve interactie met beroepspraktijk, daarentegen wordt door iedereen sterk benadrukt (zie tabel 28).

Indien wij afgaan op de aard van de genoten opleiding blijkt het volgende: Het zijn de technisch opgeleide informanten die meer nadruk leggen op een afhankelijk $\mathrm{HBO}$, sociaal-pedagogisch opgeleiden achten dit aspect minder gewenst, terwijl economisch-administratief opgeleiden het midden houden tussen deze twee stellingen.

Vanuit de positie bezien is het de intermediaire sector die een ten opzichte van de beroepspraktijk afhankelijk HBO benadrukt, gevolgd door de sector arbeid. Onderwijsinformanten vinden een afhankelijk HBO duidelijk minder wenselijk. Hierbij moet worden aangetekend dat de relatieve hoogte van de schaalscores aangeven dat men zich ower het algemeen niet duidelijk uitspreekt over een afhankelijk HBO. De strategie uit de vorige paragraaf volgend voor de interactie-aspecten laat zien dat alleen het aspect afhankelijkheid van het HBO samenhangt met de opleiding en de positie. Verwezen wordt naar tabel 32. Informanten uit de intermediaire sector achten de afhankelijkheid van het HBO kennelijk een meer wenselijk discussiethema dan mensen uit het onderwijs (resp. $69 \%$ vs. $33 \%$ ).

Kijken we naar opleiding, dan blijken mensen met een technische opleiding de wenselijkheid van een afhankelijk HBO te benadrukken. Dit verband ligt omgekeerd voor mensen met een sociaal-pedagogische opleiding (resp. $72 \%$ vs. $47 \%$ ). Om technische redenen trekken wij de opleidingscategorieën "economisch-administratief" en "technisch" samen en vergelijken de aldus gevormde 
categorie met de "sociaal-pedagogen". Voorts betrekken wij alleen de groepen arbeid en onderwijs in de vergelijking. Binnen arbeid en onderwijs speelt de opleiding (gedichotomiseerd als boven beschreven) kennelijk geen rol: de aard van de opleiding zegt niets over de mate van een gewenst afhankelijk HBO. Een verband tussen opleiding en een hoge score op de schaal "afhankelijk HBO" bestaat wel binnen de groep zonder een reputatie (Phi $=.15$ ), maar niet in de groep mét een reputatie.

Tabel 32: AFHANKELIJK HBO ALS INTERACTIEKENMERK GESPECIFICEERD NAAR POSITIE (V7) RESP. OPLEIDING INFORMANT (V3) (Percentages tussen haakjes)

\begin{tabular}{|c|c|c|c|c|}
\hline $\begin{array}{l}\text { Afhankelijk HBO } \\
\text { CONC } 23\end{array}$ & $\begin{array}{l}\text { Positie (V7) } \\
\text { Arbeid }\end{array}$ & Onderwijs & Intermediair & Totalal \\
\hline $\begin{array}{l}50 \% \text { laag } \\
50 \% \text { Hoog }\end{array}$ & $\begin{array}{l}107(44) \\
136(56)\end{array}$ & $\begin{array}{l}50(67) \\
25(33)\end{array}$ & $\begin{array}{l}13(31) \\
28(69)\end{array}$ & $\begin{array}{l}170(47) \\
189(53)\end{array}$ \\
\hline \multirow[t]{2}{*}{ Totaal } & $243(100)$ & $75(100)$ & $41(100)$ & $359(100)$ \\
\hline & \multicolumn{4}{|c|}{$\begin{array}{l}\text { Chi-kwadrant }=16.3(p<.05) \\
\text { Cramer's V }=.21\end{array}$} \\
\hline $\begin{array}{l}\text { Afhankelijk HBO } \\
\text { CONC } 23\end{array}$ & $\begin{array}{l}\text { Oplleiding (V3) } \\
\text { Soc.-pedag. }\end{array}$ & Econ.-Admin. & Technïsch & Totaal \\
\hline $\begin{array}{l}50 \% \text { Laag } \\
50 \% \text { Hoog }\end{array}$ & $\begin{array}{l}82(53) \\
74(47)\end{array}$ & $\begin{array}{l}56(46) \\
66(54)\end{array}$ & $\begin{array}{l}17(28) \\
43(72)\end{array}$ & $\begin{array}{l}155(46) \\
183(54)\end{array}$ \\
\hline Totaal & $156(100)$ & $122(100)$ & $60(100)$ & $338(100)$ \\
\hline
\end{tabular}

Chi-kwadraat $=10.2(p<.05)$

Cramer's $\mathrm{V}=.17$

\section{Legenda}

Soc.-pedag. = opleiding van sociaalwetenschappelijke of pedagogische aard

Econ-Admin. = opleiding van economisch/administratieve aard

Technisch = opleiding van technische aard

Kennelijk verschillen de mensen met een reputatie op dit punt niet met elkaar van mening. Men zou nu kunnen verwachten dat een dergelijk verband ook binnen de categorieën van betrokkenheid bij de discussies zou optreden. Dit blijkt echter niet het geval te zijn. Met andere woorden: opleiding "verklaart" niet rechtstreeks de gewenste afhankelijkheid van het $\mathrm{HBO}$, maar loopt via betrokkenheid bij de discussies (V10). Eenzelfde beeld vinden wij bij betrokkenheid bij beleidsontwikkeling (V11).

Ook hier blijkt (evenals bij de kwaliteits-aspecten) dat de mate van betrokkenheid meer zegt over de visies dan de zogeheten "sociaal-structurele achtergrondkenmerken". 
Binnen de categorieën "niet betrokken" en "wel betrokken" laat het aspect positie ook verschillen zien: binnen de groep "wel betrokken" is er een significant verband tussen positie en afhankelijkheid van het $\mathrm{HBO}$ als thema. 71 $\%$ van de onderwijs-mensen is minder geporteerd voor een afhankelijk $\mathrm{HBO}$ tegen 43 \% van de arbeidsmensen. Het zijn de vertegenwoordigers wit de beroepspraktijk die duidelijk meer de nadruk leggen op de afhankelijkheid van het $\mathrm{HBO}$.

Samenvattend: Overzien we het domein van de interactie dan kunnen wij concluderen, dat een autonoom $\mathrm{HBO}$ en de gewenste aard van de interactie (in termen van een open dialoog en het volgen van ontwikkelingen in de beroepspraktijk) geen twistpunten vormen. Een sterk autonoom HBO wordt niet gewenst. Een interactie van $\mathrm{HBO}$ en beroepspraktijk waarbij het $\mathrm{HBO}$ de praktijk attent volgt en in een open dialoog staat met het werkveld wordt door allen sterk benadrukt. Daarentegen lijkt het thema "afhankelijk HBO" voor verdeeldheid te zorgen: er wordt minder prioriteit aan toegekend en er wordt verschillend over gedacht door mensen met een uiteenlopende opleidingsen arbeidsachtergrond.

Ook hier is de mate van betrokkenheid bij beleidsontwikkeling een belangrijk kenmerk, waarmee men diverse groepen kan onderscheiden.

Ten aanzien van de afhankelijkheid van het HBO zijn het vooral de mensen uit het onderwijs met een hogere reputatie die een tot de beroepspraktijk afhankelijk HBO minder wenselijk achten.

Wij stellen vast dat de interactie-schalen de meningen minder doen variëren dan verwacht werd in een benadering die uitging van tal van divergenties in visies, scherp te onderscheiden partijen en spanningsbronnen in de relatie onderwijs- en beroepspraktijk.

\subsection{PRIORITEITEN BINNEN HET DOMEIN STRUCTUUR EN ORGANISATIE}

De aspecten die met betrekking tot de structuur van het HBO zijn onderzocht laten weinig verschillen zien. Bovendien wordt aan structuur-aspecten relatief een lage prioriteit toegekend. Variantie-analyse toont aan dat het voornamelijk de reputatie is die voor opmerkelijke verschillen zorgt, mensen zonder reputatie kennen aan interne en externe flexibiliteit $(31,32)$ alsmede aan een breed opleidend HBO ( 41 , verder aan te duiden als breed HBO) meer prioriteit toe dan mensen met een reputatie. 
Alleen interne flexibiliteit (wederom gedichotomiseerd in $50 \%$ lage en $50 \%$ hoge scores) laat een relevant verband met (de door informanten genoten) opleiding zien, zoals blijkt uit de onderstaande tabel:

Tabel 33: INTERNE FLEXIBILTET VAN HET HBO ALS STRUCTUURKENMERK GESPECIFICEERD NAAR OPLEIDING (V3) (Percentages russent haakjes)

\begin{tabular}{lllll}
\hline $\begin{array}{l}\text { Interne } \\
\text { flexibiliteit } \\
\text { CONC 31 }\end{array}$ & $\begin{array}{l}\text { Opleiding (V3) } \\
\text { Soc.-pedag- }\end{array}$ & Econ-Admin. & Technisch & Totaal \\
\hline $50 \%$ Lalag & $65(42)$ & $63(53)$ & $37(63)$ & $165(50)$ \\
$50 \%$ Hoog & $89(58)$ & $57(47)$ & $22(37)$ & $168(50)$ \\
\hline Totaal & $154(100)$ & $120(100)$ & $59(100)$ & $333(100)$ \\
\hline
\end{tabular}

Chi-kwadraat $=7.8(\mathrm{p}<.05)$

Cramer"s $V=.15$

Het berekende verband is relevant (Cramer's $V=.15$ ) en komt tot stand doordat mensen met een sociaal-pedagogische opleiding het aspect interne flexibiliteit (kleinschaliger; individueler HBO) meer benadrukken dan mensen met een economisch-administratieve of technische opleiding (resp. 58, 47 en $37 \%$ ).

Het verband tussen opleiding en de wenselijkheid toegekend aan interne flexibiliteit is aanwezig binnen de groep zonder reputatie: dit verband antbreekt daarentegen in de groep met reputatie. Het zijn met name de sociaal-pedagogisch opgeleiden zonder reputatie die de interne flexibiliteit benadrukken (61 $\%)$. De "overige opgeleiden" zonder reputatie zijn daar minder voor te vinden $(44 \%)$. Het vastgestelde verband is evenwel niet sterk $(\mathrm{Phi}=.16)$.

Vergelijking van de scores van informanten uit de sectoren arbeid en onderwijs (binnen de twee reputatie-groepen) laat zien dat er geen verband bestaat tussen positie en interne flexibiliteit. Een identieke conclusie trekken wij uit de partiële tabellen met opleiding en interne flexibiliteit onder controle van de positie: ook hier zijn geen significante verbanden aangetoond.

Het domein structuur kunnen wij als volgt samenvattend typeren. Over het geheel genomen wordt aan de aspecten interne en externe flexibiliteit, breed en specifiek opleidend $\mathrm{HBO}$ geen hoge prioriteit toegekend. Zij staan wat dat betreft onderaan (zie tabel 28). De reputatie die actores genieten blijkt samenhang te vertonen met de verschillen in scores op interne flexibiliteit, externe flexibiliteit (de flexibele relatie met de beroepspraktijk) en breed opleidend HBO: (d.w.z. een HBO dat een algemeen vormende voorbereiding biedt op maatschappelijke taken). Verdeling van de scores (in 50 procent laagste en 50 procent hoogste scores, ten einde deze reputatie-groepen nader te kunnen identificeren) laat zien dat voor de groep zonder reputatie een onderscheid 
moet worden gemaakt naar opleiding. De aard van de opleiding speelt geen rol in de groep met reputatie. Positie - d.w.z. de rraag waar men werkt blijkt binnen beide "reputatie"-groepen geen discriminerende variabele te zijn. Binnen het domein structumr en organisatie werden de vier onderscheiden concepten - over het algemeen genomen - laag geprefereerd. Ze lieten weinig relevante associaties zien met sociale achtergrondkenmerken.

\subsection{CONCLUSIES}

Er zijn dertien schalen gebruikt om visies in kaart te brengen. Dit is gedaan middels de vergelijking van de somscores (volgens het additieve schaalmodel van Likert). Analyse toont aan dat er op een aantal schalen relevante verschillen in gemiddelden zijn tussen de verschillende categorieën van respondentkenmerken (zie tabel 29). De schalen zijn vervolgens per domein (zoals in de hoofdstukken $3 \mathrm{t} / \mathrm{m} 5$ beschreven) aan de orde gekomen en de meest relevante verschillen zijn beschreven.

Van de zes kwaliteitsaspecten blijken "organisatie en planning" en "management ondersteunende technieken" samen te hangen met positie en/of betrokkenheid bij de beleidsontwikkeling. Organisatie en planning als kwaliteitseis wordt vooral benadrukt door informanten uit het onderwijs en daarbinnen vooral door mensen, die actief participeren in de beleidsontwikkeling. Managementtechnieken worden vooral benadrukt door informanten uit de sector arbeid die aan beleidsontwikkeling bijdragen.

Van de drie interactie-aspecten blijkt afhankelijkheid van het $\mathrm{HBO}$ ten opzichte van de beroepspraktijk een punt te zijn dat de meningen doet divergeren. Het zijn mensen met een reputatie op het gebied van de relatie HBO en beroepspraktijk die van mening verschillen: onderwijsmensen zijn minder geporteerd voor een afhankelijk HBO dan informanten uit de sector arbeid. Zowel onderwijs- als arbeidsmensen zijn het eens over de autonomie van het HBO: volstrekte autonomie is minder gewenst.

Aan de structuur-aspecten wordt over het geheel genomen geen hoge prioriteit toegekend. Ook hier is reputatie een belangrijk onderscheidingscriterium. Maar nu omgekeerd: mensen met een reputatie zijn het eens over de wenselijkheid van interne flexibiliteit, i.t.t. mensen die deze reputatie niet hebben. Binnen de laatstgenoemde groep blijkt de opleiding een rol te spelen: mensen met een sociaal-pedagogische achtergrond benadrukken de interne flexibiliteit meer dan mensen met een andere opleiding.

Het veertiende concept, "de regelgeving", is - zoals in hoofdstuk 7 reeds werd aangegeven - verder buiten beschouwing gelaten omdat het geen relevante samenhang te zien geeft met de overige dertien concepten. 


\section{Conclusies en perspectieven}

\subsection{INLEIDING}

In dit hoofdstuk wordt allereerst een overzicht gepresenteerd van het theoretisch traject van het onderzoek (paragraaf 9.2). Vervolgens worden de voornaamste conclusies getrokken rond de aspecten steekproeftrekking, dataverzameling en validiteit van het empirisch deel van het onderzoek (paragraaf 9.3).

Paragraaf 9.4 gaat in op conclusies met betrekking tot de aangetroffen dimensionaliteit. Paragraaf 9.5 handelt over de prioritering van de hoofdcomponenten. De visies op de oorspronkelijke kernelementen "kwaliteit-interactie-structuur" vormen paragraaf 9.6. Ten aanzien van de expertness van de geraadpleegde informanten wordt concluderend gerapporteerd in paragraaf 9.7. Het hoofdstuk vervolgt met een correspondentie-analyse en een grafische weergave van de daarbij geconstateerde samenhangen tussen kenmerken én visies van respondenten (paragraaf 9.8).

De perspectieven die er zijn voor het werken in concreto aan de verhouding van onderwijs en arbeid en enkele suggesties voor - methodische - follow up van deze studie, worden geschetst in paragraaf 9.9 .

\subsection{RESUMÉ VAN HET THEORETISCHE DEEL}

Tegen de achtergrond van een beschrijving van de maatschappelijke functies van het Hoger Beroepsonderwijs en een schets van de wijzen waarop de relatie van onderwijs en arbeid kan worden beoordeeld, hebben wij visies op de relatie van het Hoger Beroepsonderwijs en de beroepspraktijk in kaart gebracht. Daarin is het onderwerp eerst nader gespecificeerd naar drie gezichtspunten: de kwaliteit van de HBO-opbrengst, de aard van de interactie en de gewenste ontwikkeling van het HBO met betrekking tot zijn structuur en organisatie. Deze thema's blijken in discussies en publikaties over de spanningsmomenten in de relatie van het $\mathrm{HBO}$ en beroepspraktijk, de rode draad te vormen. Vervolgens zijn deze aspecten theoretisch uitgewerkt. Wij stelden vast dat in de diverse benaderingen van het kwalificatiebegrip steeds de relatie/interactie 
van $\mathrm{HBO}$ en beroepspraktijk aan de orde is. Uitgaande van de tweedeling tussen technisch-instrumentele en sociaal-normatieve kwalificaties, hebben wij in het onderdeel "toekomstige kwaliteit" veertien elementen verder ontleed in een aantal aspecten. Het thema "interactie" is besproken vanuit een aantal visies op kenmerken van de relatie tussen het HBO en de beroepspraktijk. Pro- of re-activiteit en de mate van professionalisatie en de heterogeniteit zijn daarbij aan de orde gekomen. De toekomstige ontwikkeling van het HBO qua "structuur en organisatie" is besproken vanuit de diverse visies over toekomsttrends die daaromtrent in de literatuur te vinden zijn. Over dit deel zijn negen aspecten nader gespecificeerd en voorgelegd aan de informanten.

Over de vraag hoe de verhouding van onderwijspraktijk en beroepspraktijk er in de toekomst uit zou moeten zien, lopen de meningen uiteen, gelet op de in het theoretische deel van deze studie beschreven spanningsmomenten tussen onderwijs en arbeid. Gezien de variëteit die de respondentengroep qua scores aan de dag legt, luidt de (algemene) conclusie dat de meningen inderdaad verdeeld zijn. Visies op de verhouding van twee in ontwikkeling zijnde maatschappelijke grootheden als onderwijs en arbeid zijn, lijken effectbeladen.

In de discussies erover, frapperen zowel de lange duur, en het cliche-matige karakter van oor- en vooroordelen. Om het taalveld te verduidelijken werd een onderzoeksdesign ontworpen om in kaart te brengen wat er aan visies en verwachtingen bij relevante actores leefde. De informantengroep werd samengesteld middels een vooronderzoek.

\subsection{CONCLUSIES MET BETREKKING TOT DE DATAVERZAMELING IN VOOR- ONDERZOEK EN SURVEYONDERZOEK}

\section{Vragenlijst en steekproef}

Via een voorgecodeerde vragenlijst zijn de items voorgelegd aan een steekproef van relevante actores in Limburg. Een relevante actor is iemand die aan minimaal een van de twee voorwaarden voldoet: de persoon moest op grond van zijn/haar taakstelling te maken hebben met het HBO (de positie) en/of de persoon in kwestie moest een bepaalde deskundigheid genieten op het gebied van de aansluitingsproblematiek van het $\mathrm{HBO}$ en de beroepspraktijk (de reputatie). De reputatie is vastgesteld middels toepassing van de reputatiemethode uit de sociaal-netwerkanalyse.

Wij concludeerden reeds tot het feit dat de reputatie, toegekend in het uitgevoerde vooronderzoek, niet noemenswaard veranderde door scores - ach- 
teral toegekend - in het survey-onderzoek. Een nadeel van de toepassing der reputatie-methode zou in dit geval mogen heten dat de informantengroep voor een groot deel uit experts bestond die op grond van de opgedane ervaring en de mate van betrokkenheid kumnen neigen naar dezelfde visies.

\section{De respons}

De respons op het survey-onderzoek bedroeg $73 \%$. Het onderwerp was voor respondenten kennelijk relevant genoeg hun medewerking te verlenen. Hierbij moet worden aangetekend dat men in veel gevallen (op grond van het vooronderzoek) op de hoogte was van het onderzoek en zijn medewerking had toegezegd.

Meer dan $95 \%$ van de informanten was in toezending van een samenvatting geïnteresseerd. Dit gegeven, gevoegd bij het hoge responspercentage, geeft grond aan de stelling dat het thema de toekomstige verhouding van onderwijspraktijk en beroepspraktijk, de geraadpleegde experts kennelijk aanspreekt.

\section{De infornantengroep}

De informantengroep (gevormd door het gecombineerde gebruik van de positieen de reputatiemethode) kan als een representatieve afspiegeling worden beschouwd van de populatie "experts inzake de aansluiting van HBO en beroepspraktijk in het geografisch domein van het onderzoek, i.c. de provincie Limburg". De kenmerken waarvan de verdeling in de steekproef (het aantal uitgezette enquêtes) vooraf bekend is, zijn de spreiding over de drie sectoren (arbeid, onderwijs en intermediair), de verdeling van de aard van de arbeidsorganisaties en de verdeling van de ingraad.

Wij stelden vast dat de respons een goede afspiegeling was van de steekproef. De antwoordbereidheid van mensen uit de sector arbeid is hoger dan die van mensen uit de sector onderwijs (resp. $78 \%$ en $60 \%$ ). Niettemin ontlopen de verdelingen in de steekproef en de respons elkaar niet veel: in de respons is de proportie mensen uit de sector arbeid hoger dan in de steekproef (resp. $68 \%$ en $63 \%$ ). Het omgekeerde beeld geldt voor de mensen uit de onderwijssector, terwijl de mensen uit de intermediaire in beide verdelingen in gelijke proporties vertegenwoordigd zijn.

Die grotere antwoordbereidheid komt vooral op rekening van de mensen uit de industriële bedrijfstakken en de kwartaire sector (respons resp. $95 \%$ en $82 \%)$. Mensen afkomstig uit de dienstensector zijn in deze iets terug-houden- 
der. Maar ook ten aanzien van dit kenmerk concluderen wij dat de respons de steekproef goed weerspiegelt. Hetzelfde geldt voor de reputatie, uitgedrukt in de zogeheten ingraad-verdeling. Omdat het om relatief lage aantallen gaat moet aan de verschillen in percentages geen al te groot gewicht worden toegekend. Grosso modo echter wijken de steekproef en de responsverdeling niet veel van elkaar af. Als conclusie geldt dat de respons een afspiegeling is van de steekproef zoals die is samengesteld. Er is geen reden om systematische non-response te veronderstellen.

\section{Validiteitsaspecten}

Aan de respondenten zijn uitspraken gepresenteerd, met betrekking tot aspecten die bij het denken over de toekomstige gewenste relatie van HBOen beroepspraktijk relevant geacht werden. De opinies zijn gepeild, deze hadden alle betrekking op de vraag in welke mate toekomstige ontwikkelingen wenselijk werden geacht.

Er was geen algemeen aanvaard meetinstrument aanwezig voor de drie domeimen in de verhouding van hoger beroepsonderwijs en de beroepspraktijk, soortgenootvalidering is niet mogelijk. De predictieve validiteit is er evenmin; we weten niet met welke zaken de wenselijkheden, aangegeven binnen de drie domeinen, samenhangen. Rest het complex aan problemen dat wordt aangeduid met de term: "face validity", die nagestreefd werd door uit de uitvoerige discussie op dit punt de kern-aspecten te destilleren. De gekozen indicatoren lijken geldig omdat ze na literatuurstudie, reflectie en kennisname door anderen dat lijken aan te duiden, waarnaar men op zoek is. De proefvorm van de enquête en de opzet is in fora besproken en aangevuld. De kernvraag daarbij was of gesprekspartners alle aspecten aantroffen die ze relevant achtten voor de bedoelde discussie.

Het researchontwerp is door een forum van experts in de praktijk van onderwijs en arbeid en wetenschappelijk begeleiders beoordeeld. Deze procedure leidde tot een zekere forumvaliditeit. Een uitgesproken objectivering van de validiteit, in de zin van referentie aan hetgeen ander onderzoek heeft opgeleverd, is echter niet te geven.

\subsection{CONCLUSIES MET BETREKKING TOT DIMENSIONALTETT}

$\mathrm{Na}$ de beschrijving van een aantal kernconcepten uit de actuele discussie omtrent de verhouding van onderwijs en arbeid is o.b.v. de verzamelde data een dimensionaleringsonderzoek uitgevoerd. 
Bij de theoretische analyse werd geconstateerd dat de discussie over de aansluiting van beroepsonderwijs en beroepspraktijk spanningsmomenten bevat en een lang verleden heeft. Veel van de in discussies en publikaties gedane uitspraken zijn weinig specifiek en geven de uiteenzettingen een zeer polymorf aanzien. Het doel van deze studie is enige klaarheid aan te brengen in de discussie over de verhouding van onderwijs en beroepspraktijk, de visies transparant te maken en zicht te krijgen op de eventuele verschillen tussen de visies die mensen, (vanuit verschillende posities), op de problematiek hebben. Daartoe zija met behulp van de resultaten van principale componenten-analyse zes factoren onderscheiden. Deze factoren waren voor specifieke subgroepen invariant en kwamen redelijk overeen met het gehanteerde conceptuele schema.

De microscopische structuur die binnen de afzonderlijke factoren aanwezig was werd nader vastgesteld. Daarbij werd de conclusie getrokken, dat de relevante actores zes kwaliteitsaspecten hanteren, naast drie interactieaspecten en vier structuuraspecten. De kwaliteitsaspecten passen binnen het in hoofdstuk 3 gemaakte onderscheild tussen technisch-instrumentele en sociaal-normatieve kwalificaties; de interactie-aspecten passen binnen het gemaakte onderscheid autonoom en afhankelijk $\mathrm{HBO}$. Het thema structuur omvat twee aspecten die wijzen op de flexibiliteit van het $\mathrm{HBO}$ (intern/extern) en twee aspecten die wijzen op de aard van het onderwijs zoals het HBO dit zou moeten geven (breed versus specifiek opleidend $\mathrm{HBO}$ ). (zie ook Bijlage 1, blad 1)

De analyses van het scala aan ontwikkelingen, dat in mindere of meerdere mate wenselijk werd geacht, leerde dat het denken over en het beoordelen van de toekomst door de respondentengroep als totaal, maar ook binnen onderscheiden subgroepen (naar sectoren, naar opleidingsachtergrond) herleidbaar is tot 13 hoofdcomponenten.

\subsection{CONCLUSIES MET BETREKKING TOT DE PRIORITERING VAN DE HOOFDCOMPONENTEN}

Uit de rangordening (op basis van de schaalgemiddelden) van deze 13 hoofdcomponenten blijkt dat het bevorderen van een actieve interactie in termen van een open dialoog tussen onderwijspraktijk en beroepspraktijk duidelijk het meest wenselijk wordt geacht.

Een autonoom HBO wordt over het algemeen minder wenselijk geacht. De kwaliteitsaspecten "organisatie/planning" en "zelfstandigheid" staan eveneens hoog op de prioriteitenlijst. Ook aan communicatieve vaardigheden als kwaliteitsaspect wordt een hoge voorkeur gegeven. 
De structuuraspecten (zowel de interne en externe flexibiliteit als het breed en specifiek opleidend $\mathrm{HBO}$ ) blijven qua toegekende wenselijkheid daarbij achter. Wij vergeleken de rangordening van de genoemde aspecten op basis van scores van mensen uit de sectoren arbeid, onderwijs en intermediaire organisaties in tabel 34 .

Een aantal zaken is direct uit deze afbeelding af te leiden: ten eerste staan de kwaliteitsaspecten $(11,12,13,14,51$ en 52) relatief hoog in de rangordening; daarnaast lopen de meningen uiteen over de mate van aandacht die men zou moeten schenken aan communicatieve vaardigheden (12), zelfstandigheid (11) en samenwerking (13).

De interactie-aspecten $(21,22$ en 23$)$ nemen in de rangordening verschillende plaatsen in. De aard van de interactie (22) staat hoog in de rangordening en vormt geen twistpunt, in tegenstelling tot de afhankelijkheid van het $\mathrm{HBO}$ (23). Daarover verschilt men van mening. Over autonoom HBO (21) is men het volledig eens: het is het minst gewenst en neemt in de rangorde telkens de laatste plaats in.

De structuuraspecten $(31,32,41$ en 42$)$ staan alle relatief laag in de rangordening en men kent aan deze aspecten, binnen de afzonderlijke sectoren, nagenoeg dezelfde lagere wenselijkheid toe.

Over het algemeen is de rangorde binnen de drie subgroepen parallel. Wij stelden reeds vast dat de denkkaders van respondenten uit de drie sectoren dezelfde waren en kunnen nu concluderen tot het bestaan van nagenoeg identieke preferentieprofielen indien wij de scores op dertien concepten rangordenen en specificeren naar sector.

Tabel 34: Weergave van de rangorde der scores op dertien concepten met betrekking tot de relatie $H B O$ en beroepsprakrijk, gespecificeerd naar sector Arbeid, Ondenwijs en Intermediaire organisaties

\begin{tabular}{lcccc}
\hline Rangorde "overall": & \multicolumn{3}{c}{ Rangorde binnen sector: } \\
& Allen & Aibeid & Onderwijs & Intermediair \\
\hline Aard interactie & $(22)$ & $(22)$ & $(12)$ & $(22)$ \\
Comm. vaardigheden & $(12)$ & $(12)$ & $(22)$ & $(11)$ \\
Zelfstandigheid & $(11)$ & $(11)$ & $(11)$ & $(12)$ \\
Organisatie/planning & $(14)$ & $(14)$ & $(14)$ & $(14)$ \\
Samenwerking & $(13)$ & $(51)$ & $(13)$ & $(13)$ \\
Leidinggeven & $(51)$ & $(13)$ & $(51)$ & $(51)$ \\
Managementrechnieken & $(52)$ & $(23)$ & $(52)$ & $(23)$ \\
Afthankelijk HBO & $(23)$ & $(52)$ & $(32)$ & $(52)$ \\
Externe flexibiliteit & $(32)$ & $(32)$ & $(23)$ & $(32)$ \\
Breed HBO & $(41)$ & $(41)$ & $(41)$ & $(41)$ \\
Interne flexibiliteit & $(31)$ & $(31)$ & $(31)$ & $(31)$ \\
Specifiek HBO & $(42)$ & $(42)$ & $(42)$ & $(42)$ \\
Autonoom HBO & $(21)$ & $(21)$ & $(21)$ & $(21)$ \\
\hline
\end{tabular}


In hoofdstuk 8 is ingegaan op de samenhangen tussen de diverse beoordelingsaspecten en de sociaal-structurele achtergrondkenmerken. Er werden weinig samenhangen met kenmerken van deze soort aangetroffen. Gegeven de constatering dat bepaalde samenhangen alleen bestaan onder het gezichtspunt van actieve participatie in de discussies en de ontwikkeling van beleid, mogen wij aannemen dat de responsgroep inderdaad uit terzake kundige mensen bestond.

Ofschoon er een duidelijke paralleliteit in visies is zijn de informanten met een reputatie van expertness het zeker niet op alle punten met elkaar eens. Van de zes kwaliteitsaspecten blijken "organisatie/planning" en "managementtechnieken" punten van uiteenlopende beoordeling te zijn.

Van de drie interactie-aspecten blijkt de afhankelijkheid van het HBO de meningen uiteen te doen lopen.

Over de structuuraspecten zijn de experts het overigens onderling meer eens; de "niet"-experts (informanten zonder de reputatie expert te zijn) verschillen van mening over de interne flexibiliteit.

Wij geven thans, per domein, de voornaamste bevindingen kort weer.

\subsection{CONCLUSIES MET BETREKKING TOT DE OORSPRONKELUKE HOOFDDOMEINEN KWALITEIT-INTERACTIE-STRUCTUUR}

\subsubsection{Kwaliteit}

Het aspect van de kwaliteit van de output is, van essentieel belang met het oog op de taken van het HBO thans en in de toekomst.

HBO is beroepsonderwijs en het voorbereiden op een beroep is de kernfunctie van het HBO. De wijze waarop het HBO dat kan doen en de mogelijke accenten daarbij, zijn in dit onderzoek betrokken.

Het kwaliteitsaspect is benaderd vanuit de beschrijving van de mogelijke kwaliteitskenmerken van toekomstige opbrengst en het verzamelen en analyseren van ideeën die respondenten op dat punt hebben. Er is altijd een zekere opbrengst van onderwijs (op te vatten als de resultante van leerlingen-capaciteiten en het onderwijsleerproces) die op tal van wijzen te normeren is. $\mathrm{Ze}$ kan worden getoetst aan "standards of performance" van het onderwijs zelf en/of aan de eisen van de praktijk. Hoe de verhouding nu is, werd niet uitputtend inhoudelijk beschreven; wel werd nagegaan hoe ze zou kunnen zijn. In de vragenlijst zijn de onderscheiden aspecten van kwaliteit daartoe nader uitgewerkt. 
Het belang van aspecten gecategoriseerd als sociaal-normatief is duidelijk gebleken. Het door Huber (1984) en andere auteurs onderlijnde belang van sociaal-normatieve kwalificaties vindt ten volle bevestiging in de resultaten van dit onderzoek. Ook de conclusies, getrokken door Polak (1983) die wezen op het aparte belang van aspecten als "praktijkgericht werken, uitdrukkingsvaardigheid en omgang met mensen" qua beroepswoorbereidende taken van het HBO, worden onderschreven.

Van een groot verschil in waardering toegekend aan de onderscheiden elementen van het aspect "kwalificatie" (te weten sociaal-normatieve en technischinstrumentele aspecten) is overigens niet gebleken (vgl. Albrecht 1979, Mertens 1981, Boon 1979, Schleucher en Maskow 1983).

Het is duidelijk dat zowel personen uit de onderwijs- als arbeidssector aandacht van het HBO voor alle concepten met betrekking tot kwaliteit wenselijk vinden; de over de gehele lijn toegekende wenselijkheden zijn boog; uitgesproken negatieve uitschieters werden niet opgemerkt.

Daarmee is vastgesteld dat het verschil in visies op toekomstige taken van het $\mathrm{HBO}$ dat in het algemeen zou bestaan tussen "arbeid" en "onderwijs" als systemen gerelativeerd moet worden. De conceptuele kaders én de toegekende preferenties zijn gelijk voor de beide subcategorieën.

Ofschoon het onderscheid in partijen - afgeleid van de traditionele tegenstelling tussen onderwijs en arbeid - en de identificatie van spanningsbronnen daartoe aanleiding gaven, is de veronderstelling dat er van fundamentele verschillen in denkkaders tussen partijen sprake is, niet bewaarheid (vgl. Teichler 1980, Van Hoof en Dronkers 1980, Hövels 1984).

Factoranalyse toonde aan dat alle betrokken partijen oordelen volgens hetzelfde conceptuele systeem.

Zowel de wijze van beoordeling (de concepten) als de toegekende beoordelingen op de additieve schalen (de individuele mate van toegekende wenselijkheid) laten geen wezenlijke verschillen zien. Het is niet zo dat aan onderwijs gebonden informanten het belang van (bijwoorbeeld) expliciete aandacht voor beroepsvoorbereiding lager zouden inschatten dan experts uit de beroepspraktijk. Integendeel ... wij concluderen dat de onderwijsexperts aan deze aspecten veelal een hogere wenselijkheid toekenden dan arbeidsexperts. Mensen binnen het onderwijs (- nog meer dan de mensen in de beroepspraktijk -) zijn doordrongen van de noodzaak om te scholen in de richting van desiderata, ontleend aan de concrete werkpraktijk. Ook dit gegeven kan de stelling "dat het onderwijs geen oog zou hebben voor de praktijk", enigszins relativeren. Dit resultaat geldt tevens als een bevestiging van de conclusies in recente ETIL-studies (ETIL 1985, 1986) over kwalitatieve knelpunten bij schoolverlaters resp. knelpunten tussen onderwijs en arbeidsmarkt. 
Voor het overige geldt als conclusie:

- sociaal-normatieve aspecten van kwalificatie scoren over het algemeen hoger dan technisch instrumentele aspecten;

- zelfstandigheid treedt ook, als een hoog geprefereerd aspect naar voren;

- indien over kwaliteit van onderwijsopbrengst wordt gesproken zijn visies op de functie van het onderwijs in het geding (vgl. SER-nota 1981, HLA 1986). De - traditionele - polariteiten in deze beoordeling zijn het accentueren van de allocatiefunctie en de directe inzetbaarheid van abituriënten versus het benadrukken van de algemene socialiserende en breed voorbereidende functie van de school. Deze twee aspecten zijn in dit onderzoek in het factor-analytische deel niet als duidelijk tegengestelde aspecten naar voren gekomen;

- het belang van een vernieuwende houding/instelling van abituriënten in de beroepspraktijk wordt over het algemeen hoog wenselijk beoordeeld;

- er is een duidelijk caesuur aan te brengen in de oordelen over toekomstige kwaliteit, tussen mensen die zichzelf een hoge danwel lage betrokkenheid bij toekomstige ontwikkelingen toekennen. Dat betekent (voor het overleg van onderwijspraktijk en beroepspraktijk) dat de experts uit beide sectoren met de grootste geïnvolveerdheid in ontwikkeling van en werken aan de toekomst, onderling qua visie een grote samenhang laten zien. De visies van mensen met lagere invloed/betrokkenheidsscores wijken daarvan vaak significant af.

Invloed cq. betrokkenheid zijn van belang zijnde variabelen gebleken. Daarvoor zijn wellicht twee verklaringen mogelijk, hier nadrukkelijk als hypothesen geformuleerd en gepresenteerd:

- er is een netwerk van experts uit beide systemen die in contact staan met elkaar, geleerd hebben van elkaar en - uit hoofde van hun gezamenlijke ervaring met het thema - kernaspecten van de toekomst van het HBO nagenoeg gelijk waarderen op de gepresenteerde punten;

- divergentie in visies en verwachtingen tussen informanten uit de onderwijs- en arbeidssector bestaat wel maar ze is minder groot dan de afstand tussen de beide subcategorieën "hoog en laag bij de toekomst betrokken experts" uit beide systemen.

Verwacht mocht worden dat in de beoordeling van de kwaliteit van de output van het $\mathrm{HBO}$ - en het aangeven van wenselijkheden voor de toekomst op dit punt - de inzetbaarheid en de functiegerichtheid (directe bruikbaarheid) van de HBO abituriënten een apart aspect vormden. Dit, omdat in het denken over de functies van $\mathrm{HBO}$ en in de visies op spanningsmomenten tussen onder- 
wijs en arbeid de polariteit tussen "functiegerichte training" en "algemene welzijnsvoorziening" frequent naar voren treedt. De verwachting dat respondenten uit de arbeidssector deze aspecten in de regel meer wenselijk achten dan respondenten uit de onderwijssector, is in dit onderzoek niet bewaarheid.

\subsubsection{Interactie}

Het tweede kernpunt was het verkennen van ideeën met betrekking tot de verhouding van de onderwijs- en beroepspraktijk. Er is altijd sprake van een onderling verband tussen onderwijs en arbeid en er is steeds sprake van zekere spanningsbronnen tussen beide. De recente Hoop nota noemt zelfs de sterke gerichtheid op de omgeving "de kern van de identiteit van het $\mathrm{HBO}^{\text {" }}$ (Hoop, 1988). Hoe zich de beide praktijken thans tot elkaar verhouden werd in deze studie kort beschreven. Hoe experts denken over de vraag op welke wijze ze zich zouden moeten gaan verhouden werd nader onderzocht. Daartoe werd ingegaan op de autonomie van opleidingspraktijk, de consequenties ervan, de invloed van de arbeidsmarkt op het onderwijs en het verschil in de onderscheiden vigerende klimaten. Het was aannemelijk dat de beoordeling door respondenten in grote lijnen neerkomt op het verschil in autonoom en afhankelijk HBO. Hierbij raken we aan de kwestie van de autonomie van het onderwijs; de kwestie in welke mate het onderwijs doel, op zichzelf mag zijn of (in een ander uiterste) volkomen ondergeschikt moet zijn aan het dictaat uit de beroepspraktijk.

De relatie van $\mathrm{HBO}$ en beroepspraktijk is primair opgevat en beschreven in termen van de oriëntatie van het $\mathrm{HBO}$ op de beroepspraktijk. De opstelling die het HBO daarbij kiest, wordt (onder meer) bepaald door de mate waarin de beroepspraktijk is geprofessionaliseerd.

Andere factoren die de aard van de interactie bepalen, zijn de heterogeniteit en veranderlijkheid van de beroepspraktijk en de autonomie en de flexibiliteit van het onderwijs (van Wieringen, 1986). Daarbij zijn ook verschillen in cultureel klimaat van het $\mathrm{HBO}$ en de beroepspraktijk een factor van betekenis in de aard van de interactie (van Gageldonk, 1983; Ritzen, 1983). De veronderstelling dat het onderwijs een (traditioneel bepaalde) gerichtheid heeft om zich van de buitenwereld af te sluiten en zich voornamelijk te bewegen binnen de grenzen van de "Pädagogische Provinz" heeft daarbij, in tal van beschouwingen, een repeterend karakter (vgl. van Kemenade, 1981).

Wanneer men nu de ideeën, zoals die in dit onderzoek zijn geobjectiveerd, nader specificeert, zijn de volgende conclusies op hun plaats:

- Onderwijs- en arbeidsexperts oordelen verschillend over de verhouding van hoger beroepsonderwijs en beroepspraktijken (vgl. tabel 34 terzake en 
de verschillende appreciaties van interactie en afhankelijkbeid daarbij). Degenen die bovendien veel betrokkenheid hebben bij de ontwikkeling van toekomstig HBO schatten de wenselijkheid van een open interactie en een actief op de beroepspraktijk georiënteerd $\mathrm{HBO}$, hoger in dan mensen met lagere betrokkenheid. Tussen de subcategorieên van informanten die met overleg en samenwerking veel ervaring hebben, treden geen grote divergenties op. Juist de niet betrokken mensen hebben onderling meer divergente visies; dit verschil loopt als een rode draad door visies van informanten uit alle sectoren.

- De idee dat autonoom HBO alleen zou worden toegejuicht door informanten uit het onderwijs en dat informanten uit de arbeidssector op dit punt essentieel met hen van mening verschillen, vindt geen steun in de data. Onderwijs- en arbeidsexperts kennen beiden de laagste wenselijkheid toe aan dit aspect.

- Alle aspecten die handelen over een primaat van de beroepspraktijk - en in overeenkomstige zin de afhankelijkheid van het $\mathrm{HBO}$ - laten verschillen in visies zien. Dat onderwijsexperts hierin minder ver gaan dan experts uit arbeid ligt voor de hand, op dit punt treden ook binnen de respondenten uit de arbeidssector grote verschillen op. Als het verschil in beoordeling van het HBO nader aan de orde is komt het onderscheid naar voren tussen de opvattingen:

- onderwijs als algemeen vormend kader - als algemene welzijnsvoorziening, versus

- onderwijs als leverancier van renderende "manpower" aan het bedrijfsleven, aan de beroepspraktijk.

Opmerkelijk is dat op dit deelgebied de betrokkenheid bij beleidsontwikkeling en de invloed daarop van de informanten nergens enige relatie hebben met de toegekende scores. Het pleidooi van de Cie. Wagner (zie Ritzen 1983, p. 116 e.v.) voor een grotere invloed van het georganiseerde bedrijfsleven op het beroepsonderwijs wordt door de resultaten van dit onderzoek enigszins bevestigd, in die zin dat de idee van een volstrekt autonoom HBO lijkt te worden afgewezen.

Door tal van auteurs (zie o.a. Beck e.a. 1976, Gordon 1974, Schouten 1977, Weisshuhn 1977) is gewezen op het bestaan van een strakke institutionele scheiding tussen onderwijs- en arbeidssystemen. Deze scheiding wordt - gelet op de visies zoals die met betrekking tot "afhankelijk $\mathrm{HBO}^{\prime}$ in kaart zijn gebracht - door respondenten niet wenselijk geacht. Het eerder gesignaleerde spanningsveld tussen onderwijs en beroepspraktijk komt echter als kernpunt 
terug uit de analyses. De gevormde concepten - gebruikt als additieve schalen - tonen tegenstellingen tussen mensen behorend tot verschillende sectoren, op het punt "afhankelijk HBO" duidelijk aan.

\subsubsection{Strucaur en organisatie}

De snelheid en flexibiliteit waarmee het onderwijs reageert op ontwikkelingen in de beroepspraktijk blijkt in tal van beschouwingen een relevant aspect te worden geacht (Ritzen 1983, van Kemenade 1981, Beck 1976, Schouten 1977 , Kraayvanger en van Onna 1985, van Wieringen 1986). Zowel de algemene als de - direct - aan de beroepspraktijk gerelateerde flexibiliteit van het HBO zijn aparte facetten gebleken in de beoordeling door geraadpleegde experts. Als belangrijk aspect resulteerde uit de data-analyse het concept met betrekking tot "flexibiliteit ten opzichte van de externe beroepspraktijk" (32). De op dit punt gespecificeerde wenselijkheden ontliepen elkaar nogal blijkens de data. Wij kunnen ertoe concluderen, dat het algemene en clichématige beeld van onderwijsmensen als categorie die geen oog zou hebben voor eisen van de beroepspraktijk én geen oog voor eventuele aanpassingen aan de zijde van het onderwijs, gericht op de praktijk, niet klopt.

Verschillen traden aan het licht bij het aangeven van de wenselijkheid van wat werd aangeduid als de algemene, organisatorische flexibiliteit van het HBO. Opmerkelijk was hier dat informanten uit de sector onderwijs verder gingen dan informanten uit de sector arbeid in het toekennen van wenselijkheid. Ook het ontbreken van de invloed van de betrokkenheid bij de discussie over en vorming van beleid is vermeldenswaard. Dit temeer daar de invloed van deze aspecten, op de andere gemeten concepten, wél vrijwel steeds kon worden geisoleerd en aangetoond. Er is geen verschil in visies in dit opzicht tussen de meer en minder bij het beleid betrokken informanten.

Uit het bovenstaande mag geconcludeerd worden dat het - althans in de kringen van de geraadpleegde experts uit de sector onderwijs - niet nodig lijkt te pleiten voor meer flexibiliteit. De in kaart gebrachte visies zijn zodanig dat ze verder gaan dan die van menige expert uit de sector arbeid. Dit gegeven sluit aan bij de opvattingen van o.a. van Wieringen (1983) die wijst op een toenemend grotere omgevingsgerichtheid wan het onderwijs.

De experts uit de arbeidssector staan meer afwijzend tegenover wat is genoemd de "flexibilisering" van de onderwijsstructuur en organisatie dan de informanten uit de onderwijssector. Het aspect van de individualisatie en decentralisatie van het $\mathrm{HBO}$ en het verlenen van meer invloed aan studenten is overigens in de beleving van de respondenten een relevant gezichtspunt. 
Breed versus specifiek HBO

Het pleidooi voor een brede initiële beroepsscholing (zie ook de Grip, 1987, p. 24 e.v.) kan passen in het kader van preventief beleid ter voorkoming van horizontale discrepanties op de arbeidsmarkt. Indien abituriënten op een breder terrein inzetbaar zijn kunnen tal van - positief geachte - effecten worden bereikt, eventuele scholingsvertragingen bij een om- of bijscholing zullen zeker ook veel geringer zijn.

Met betrekking tot het aspect breed versus specifieke HBO werden weinig opmerkelijke verschillen in visies tussen subgroepen van respondenten vastgesteld. Het aspect "specifiek gericht HBO" ontmoette over het algemeen een wat hogere waardering bij arbeidsrespondenten.

Er is geen grond voor de stelling dat specifiek, functiegericht opleidend HBO vooral de instemming van arbeidsrespondenten en breed, algemeen opleidend HBO vooral de instemming van onderwijsrespondenten zou genieten.

De idee van een breed, algemeen kwalificerend HBO - "niet elk beroep zijn eigen opleiding" - zoals dat onder meer is verwoord door Mertens (1981),vindt meer steun in de data van dit onderzoek.

\subsubsection{Een grafische weergave van de invloed van sectoren}

In het voorafgaande heeft het verschil in visies tussen personen met een uiteenlopende achtergrond de rode draad van de gedachtengang gevormd. Ter illustratie van de verschillen in scores van mensen uit verschillende sectoren volgt in schema 4 een grafische weergave van verschillen in schaalwaarden gespecificeerd naar positie (arbeid, onderwijs en intermediaire sector).

Het gaat hierbij met name om de visies op de aspecten die relevante verschillen lieten zien, uitgedrukt op de volgende additieve schalen (zie ook tabel 29 in dit verband).

- 11: zelfstandigheid

- 13: samenwerking

- 14: organisatie en planning

- 23: afhankelijk HBO

- 31: interne flexibiliteit (kwaliteitconcept)

(kwaliteitsconcept)

(kwaliteitsconcept)

(interactieconcept)

(structuurconcept) 
Schema 4: Grafische weergave van schaalwaarden mei betrekking tot zelfstandigheid (11), samenwerking (13), organisatie en planning (14), afhankelijk $H B O$ (23) en interne flexibiliteit (31) gespecificeerd naar arbeid, onderwijs en intermediaire sector.

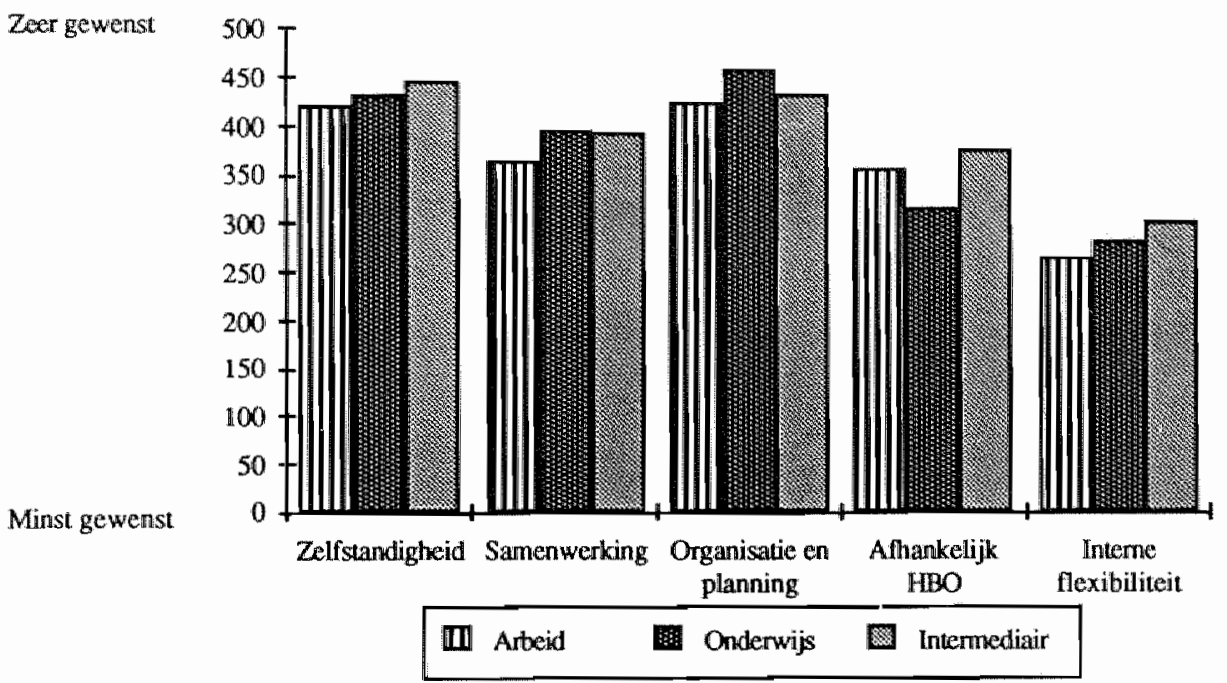

De hoge preferentie voor kwaliteitsconcepten $(11,13,14)$ die vanuit de onderwijssector aan de dag wordt gelegd is reeds eerder vastgesteld. Onderwijsrespondenten zijn consequent in het toekennen van hogere scores dan arbeidsrespondenten op deze punten. Ook ten aanzien van het aspect Afhankelijk HBO (concept 23) zijn de meningen enigszins verdeeld... hier blijven de door onderwijsrespondenten toegekende wenselijkheden echter duidelijk achter bij die van arbeidsrespondenten. Interne flexibiliteit van het $\mathrm{HBO}$ (concept 31) lijkt als aspect vooral te worden geprefereerd door informanten uit intermediaire organisaties.

\subsection{CONCLUSIES MET BETREKKING TOT DE EXPERTNESS VAN DE RESPONDENTEN}

Biografische kenmerken van de respondenten (als leeftijd, duur van de werkervaring etc.) doen er in de door hen uitgesproken wenselijkheden kennelijk weinig toe. Er is vrijwel geen samenhang van belang tussen kenmerken van deze soort en visies inzake de onderscheiden hoofdaspecten van de relatie HBO en beroepspraktijk. 
Door de toepassing van de reputatiemethode werd een apart vooronderzoek uitgevoerd, waardoor een bestand aan experts kon worden geidentificeerd. In het voorafgaande zijn de elementen, (reputatie en positie) waarop de steekproef werd samengesteld, toegelicht. We kunnen hier volstaan met de vaststelling dat het respondentenbestand geacht mag worden experts te zijn.

De variabelen waarop de onderscheiden experts hun betrokkenheid bij beleidsontwikkeling konden scoren, illustreerden de situatie binnen de sectoren onderwijs en arbeid en de verschillen op dit punt duidelijk. Qua betrokkenheid bij de toekomst van het $\mathrm{HBO}$ is er nog veel werk te doen, ervan uitgaande dat de invloed zoals bedoeld nagenoeg gelijke scores in de beide sectoren zou moeten opleveren. Wij hebben onderzocht hoe de beslissende invloed, betrokkenheid bij discussie en betrokkenheid bij beleidsontwikkeling gespreid waren over de respondenten in de subsectoren. De grafiek in schema 5 - op de volgende bladzijde - illustreert hoe uiteenlopend de positieve antwoorden waren. Het leeuwendeel van het percentage positieve antwoorden komt telkens voor rekening van onderwijs-respondenten. Ook hiermee wordt geillustreerd hoe deze aspecten met betrekking tot de ontwikkeling van het onderwijs, zaken van onderwijs- mensen zélf zijn.

Het onderzoek heeft aan het licht gebracht:

- welke groep van experts in Limburg te identificeren is,

- hoe deze - globaal - oordeelt over de gepresenteerde elementen van de relatie tussen HBO en beroepspraktijk in de toekomst,

- welke verschillen in visies er optreden en waarmee deze verschillen samenhangen. Als algemene conclusie geldt dat het beeld van de bekende, traditionele tegenstelling tussen onderwijs en arbeid relativering verdient. De beschreven empirische relaties zijn te herleiden tot de volgende algemene uitspraken

- er treden geen verschillen op tussen de denkkaders van subgroepen van experts die oordelen over de relatie van $\mathrm{HBO}$ en beroepspraktijk;

- de geanalyseerde concepten laten relatief weinig verschillen zien tussen de subgroepen van ondervraagde respondenten;

- de rangorde van de preferenties is binnen de drie meest relevante geachte subgroepen (Arbeid, Onderwijs, Intermediaire organisaties) nagenoeggelijk. 
Schema 5: Grafische illustratie wan percentage positieve antwoorden per sector op vragen naar beslissende invloed, betrokkenheid bij discussie en betrokkenheid bij beleidsontwikkeling.

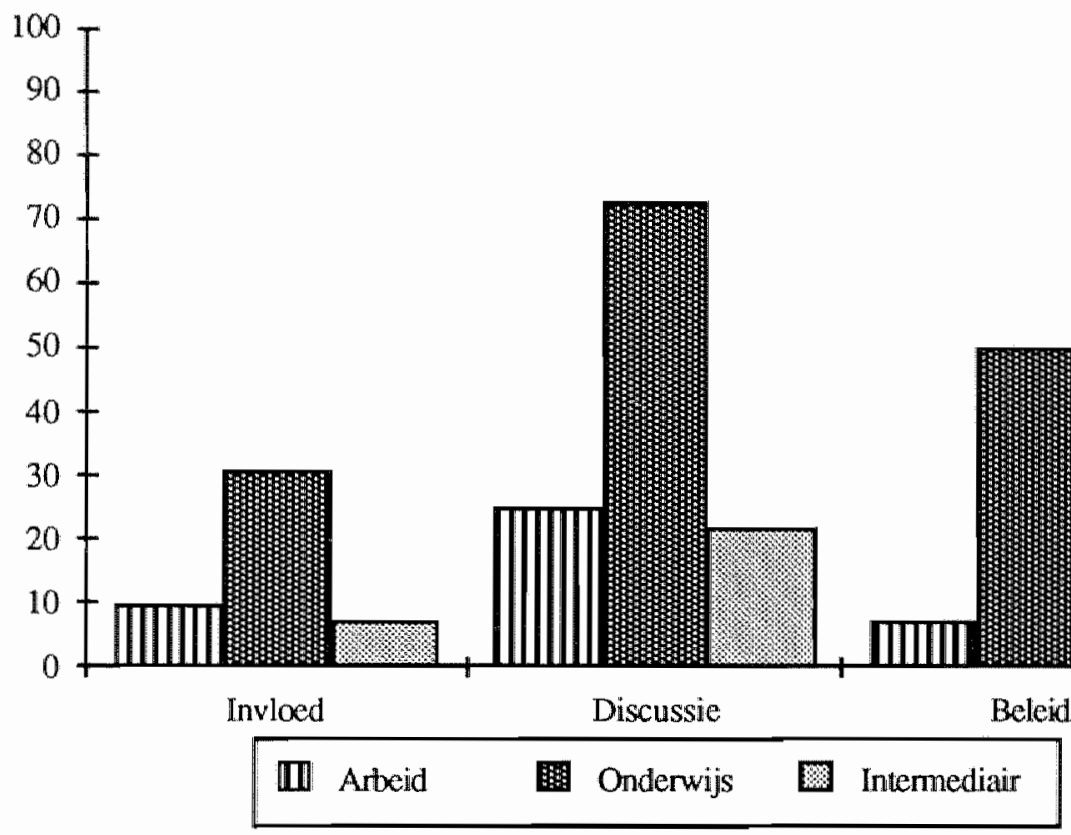

\subsection{CORRESPONDENTIE-ANALYSE}

\subsubsection{Inleiding}

Nadat in het voorafgaande is ingegaan op dimensies, patronen en prioriteiten in de visies van respondenten worden thans de voornaamste gegevens aanschouwelijk bijeen gezet. Wij schetsten daartoe een atlas van visies. Hierbij is gebruik gemaakt van correspondentie-analyse.

Dit is een techniek die men kan zien als een explorerend instrument voor de analyse van nominale gegevens. Traditioneel worden daartoe kruistabellen gehanteerd. Is de omvang van deze tabellen erg groot of gaat het om veel kruistabellen, dan is het moeilijk om (middels inspectie van de tabellen) de 
belangrijkste samenhangen voor ogen te houden en te blijven overzien. Voor die gevallen is correspondentie-analyse een goed alternatief. We zullen een toepassing van deze techniek laten zien, waarbij een groot aantal bivariate tabellen tegelijkertijd worden geanalyseerd.

In deze toepassing tracht correspondentie-analyse de samenhang in de tabellen grafisch in een twee- of meerdimensionele plot weer te geven. In het algemeen is er in een tabel sprake van samenhang, wanneer de (conditionele) verdelingen van bijvoorbeeld de kolom-variabele binnen de categorieën van de rij-variabele - kortweg rij-profielen genoemd - afwijken van de marginale verdeling in de totale populatie, die dienovereenkomstig wel het gemiddelde rij-profiel wordt genoemd. Wijken rij-profielen af van het gemiddelde rij-profiel, dan wijken ze noodzakelijk ook af van elkaar.

Het is daarom mogelijk te spreken van de mate van gelijkenis tussen categorieën onderling en ten opzichte van de totale populatie, afhankelijk van de mate waarin rij-profielen ten opzichte van elkaar en ten opzichte van het gemiddelde rij-profiel verschillen. Hetzelfde kan gezegd worden met betrekking tot de conditionele verdelingen van de rij-variabele binnen de kolommen, de kolomprofielen, en de overeenkomstige marginale verdeling, het gemiddelde kolomprofiel.

Het doel van correspondentie-analyse is gelijkenissen van categorieën onderling en ten opzichte van de totale populatie zo goed mogelijk in een plot weer te geven. In de plot worden de categorieën van de variabelen als punten weergegeven en de totale populatie als het nul-punt (de oorsprong). De techniek zorgt ervoor, dat de onderlinge afstanden tussen deze punten zoveel mogelijk de in de tabellen vast te stellen gelijkenissen reflecteren. Een dergelijke afbeelding is evenwel niet mogelijk zonder enig verlies aan informatie.

Bij de interpretatie van de figuren hanteert men de volgende regels:

- De afstanden van de rij- en kolompunten ten opzichte van het middelpunt van de figuur $(+)$, de oorsprong:

Naarmate deze afstand groter is, is de afwijking van het betreffende rijof kolom-profiel ten opzichte van het profiel van de totale groep groter.

- De afstanden van de rij-punten ten opzichte van elkaar:

Naarmate deze afstand kleiner is, is de gelijkenis tussen de categorieen, die door deze punten worden voorgesteld, groter.

- De afstanden van de rij-punten ten opzichte van de kolompunten:

Wanneer in een bepaalde rij-categorie een van de kolomcategorieën oververtegenwoordigd is, zullen de corresponderende rij- en kolompunten in de 
plot dicht bij elkaar liggen. Hoe verder deze punten van de oorsprong verwijderd zijn hoe groter de afwijkingen zijn ten opzichte van het populatiegemiddelde. Is daarentegen een kolom-categorie onderver-tegenwoordigd binnen een bepaalde rij-categorie dan liggen de betreffende punten in het plot ver uit elkaar en aan verschillende kanten van de oorsprong. De rijen kolomcategorie hangen dan negatief samen. Komt een kolomcategorie tenslotte ongeveer even vaak voor als verwacht kan worden op basis van de marginale proportie, dan staan de betreffende rijen kolompunten, gezien als vectoren vanuit de oorsprong ongeveer loodrecht op elkaar. Rij- en kolomcategorie hangen dan niet samen.

Wij zullen thans drie overzichten presenteren en daarbij uitgaan van de visies op de onderscheiden domeinen. Gelet op de centrale vraag van de studie (hoe oordelen drie partijen over drie kernthema's van de verhouding van onderwijs en arbeid) lijkt dit de juiste weg te zijn.

Per overzicht wordt een legenda gepresenteerd van de betekenis van de cursief afgedrukte visies uitgedrukt in hoge respectievelijk lage scores op de concepten, gebruikt als additieve schalen. De sociale achtergrondkenmerken van respondenten zijn in hoofdletters afgedrukt; een legenda van de afkortingen bij de sociale achtergrondkenmerken is eenmaal (bij de figuren van kwaliteit) afgedrukt. Bijlage VIII (blad $1 \mathrm{t} / \mathrm{m}$ 3) geeft een overzicht van de matrices van $\mathrm{x}$-scores en de $\mathrm{y}$-scores op basis waarvan de figuren zijn vervaardigd.

De drie partijen verschijnen als drie bevolkingsgroepen die zich op verschillende plaatsen in de ruimte blijken te vestigen, dit omdat met het verschil in positie enig verschil met betrekking tot visies gepaard gaat.

De subgroepen nemen derhalve uiteenlopende posities op de landkaart in. Ofschoon de denkkaders dezelfde zijn - vergelijk de resultaten van ons onderzoek naar de dimensies en de invariantie van de gevonden faktoren en concepten - laat dit natuurlijk het ontstaan van differentiële visies onverlet. De figuren tonen dat ook telkens aan. Ten aanzien van de onderstaand gepresenteerde figuren geldt nog dat voor de cirkels die telkens rond de achtergrondkenmerken "arbeid", "onderwijs" en "intermediair" getrokken zijn steeds een eenheidsstraal is aangehouden van .010 . 
Schema 6: Resultaten correspondentie-analyse met betrekking tot kwaliteitsaspecten

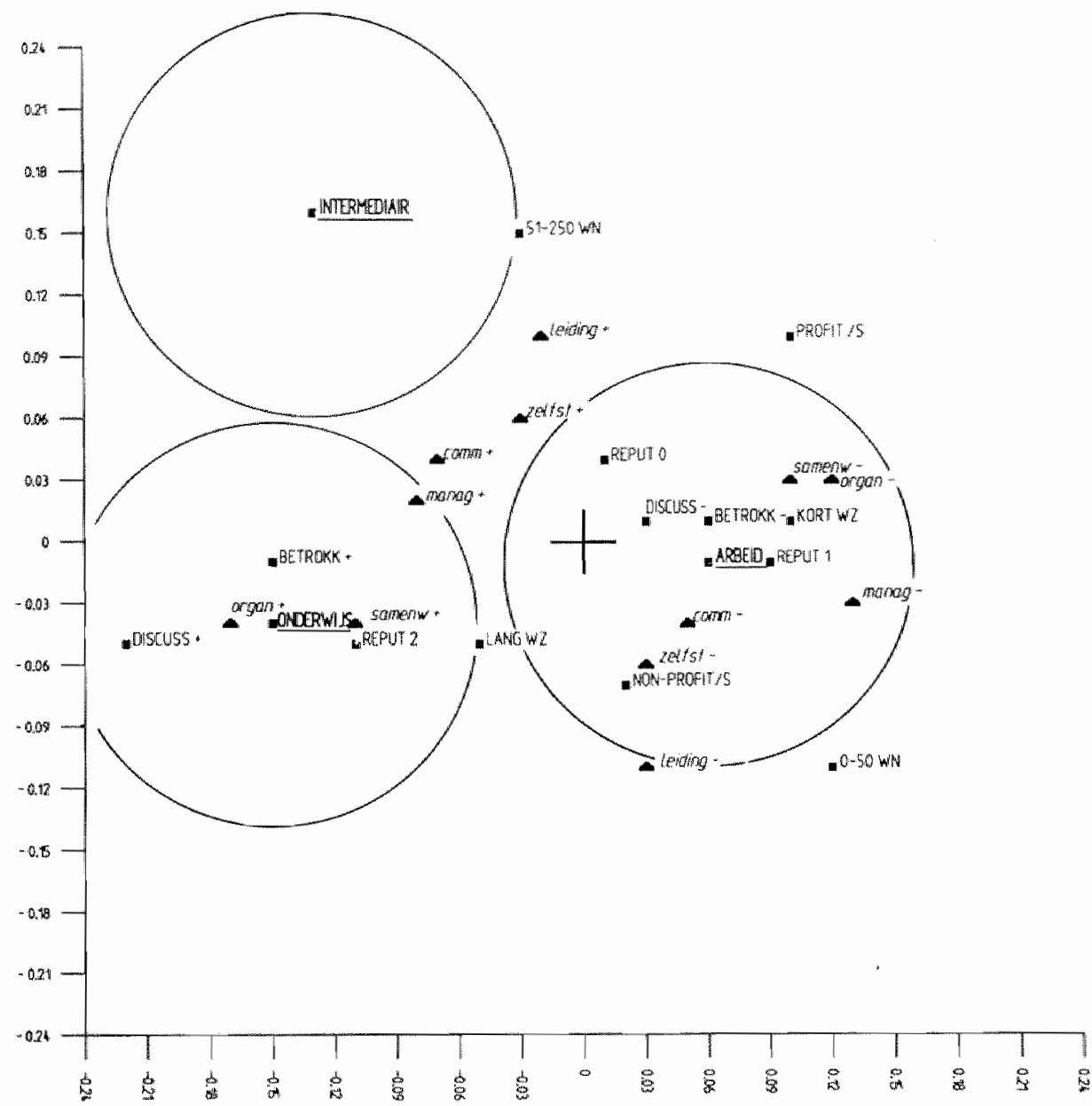




\subsubsection{Kwaliteit}

Legenda van sociale achtergrondkenmerken van respondenten

ARBEID
ONDERWIS
INTERMEDLAIR
INVLOED

BETROKK

DISCUSS

REPUT

KORT WZ

LANG WZ

PROFIT/S

NON PROFIT/S

$0.50 \mathrm{WN}$

$51-250 \mathrm{WN}$
$=$ respondenten uit de arbeidssector

$=$ respondenten wit de onderwijssector

$=$ respondenten uit intermediaire organisaties

= invoed op beleidsvoorbereiding en besluitvorming hoog = invloed: +

laag = invloed:

$=$ betrokkenheid bij beleidsontwikkeling in overleggremia

hoog = betrokk: +

laag = betrokk: -

$=$ participatie in discussies over rełatie $\mathrm{HBO}$ en beroepspralktijk

hoog = discuss:

laag $=$ discuss:

$=$ reputatje van expertness inzake de verhouding onderwijs-arbeid hoog $=$ reput: 2

laag = reput: 1

geen $=$ reput: 0

$=5$ jaar of minder werkzaan in het arbeidsproces

$=$ meer dan 5 jaar werkzaam in het arbeidsproces

$=$ behorend tot de profit-sector

$=$ behorend tot de non profit-sector

$=$ informanten uit bedrijven met $0-50$ werknemers

$=$ informanten wit bedrijuen met 51.250 werknemers

Legenda van afkortingen met betrekking tot kwaliteit:

afkorting:

$\begin{array}{ll}\text { zelfst } & = \\ \text { comm } & = \\ \text { samentw } & = \\ \text { organ } & = \\ \text { leiding } & = \\ \text { manag } & =\end{array}$

wenselijkheid van aspecten:

zelfstandigheid

communicatieve vaardigheden

samenwerking

organiseren/plannen

leidinggeven

management technieken

wenselijkheid
hoog lavag

concept

$\begin{array}{lll}+ & - & 11 \\ + & - & 12 \\ + & - & 13 \\ + & - & 14 \\ + & - & 51 \\ + & - & 52\end{array}$

- Zie hoofdstuk 7 en Bijlage nummer I

- Interpretatie van de analyse met betrekking tor kwaliteit:

De drie groepen arbeid, onderwijs en intermediaire organisaties verschillen qua visies in tal van opzichten.

Uitgaande van de bovenstaande figuur met betrekking tot kwalifeitsconcepten is het duidelijk dat arbeidsrespondenten laag scoren op kenmerken als betrokkenheid bij beleidsontwikkeling, en betrokkenheid bij discussies over beleidsproblemen van HBO en beroepspraktijk. Ook de hen toegekende reputatic is laag.

De arbeidsrespondenten kennen verder een minder uitgesproken wenselijkheid toe aan de opgenomen kwaliteitsconcepten. $\mathrm{Zij}$ zijn overwegend werkzaam in relatief kleinere bedrijwen, langer werkzaan en actief in de non-profit sector.

Voor de groep onderwijsrespondenten scoren kenmerken als betrokkenheid bij beleid en discussie, en reputatie hoog. Ten aanzien van de kwaliteitsconcepten organisatie en planning, samenwerking en managementtechnieken en communicatievevaardighedenkennendeonderwijsrespondenten hogere preferenties toe. Zij zijn duidelijk geporteerd voor het belang van sociaal normatieve vaardigheden als planning van werk, het omgaan met relevante anderen in organisaties en daarbuiten (en t.a.w. het cluster technisch-instrumentele vaardigheden) voor uitgesproken management-technieken. De informanten uit de intermediaire sector wijken duidelijk af van het algemene populatiegemiddelde wreergegeven in de corsprong $(+)$ en nemen een wat geïsoleerde positie in. Visies van mensen uit middelgrote bedrijven komen meer in de buurt van de pasitie van de intermediaire sector. 
Schema 7: Resultaten correspondentie-analyse met betrekking tot interactieaspecten

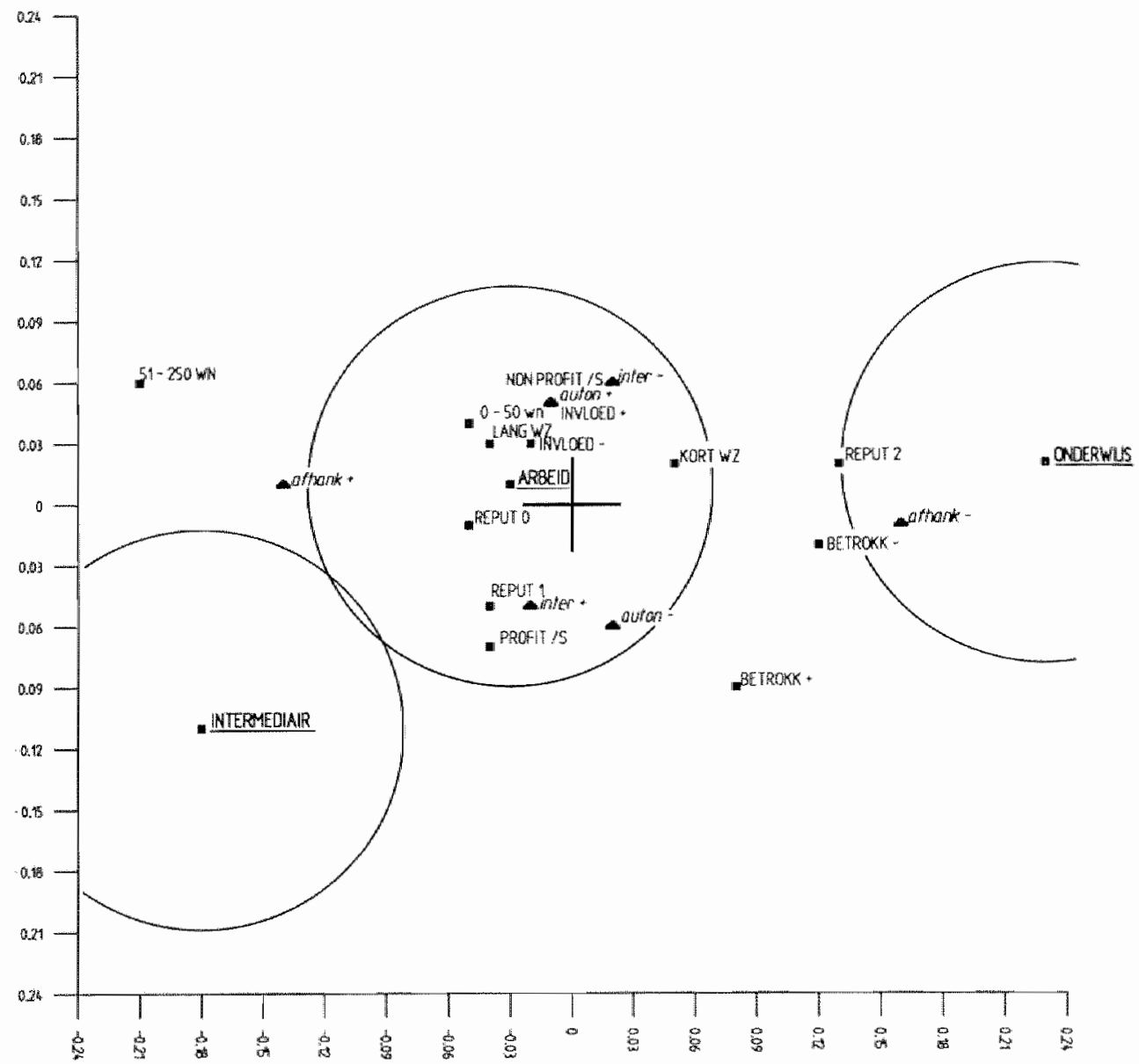




\subsubsection{Interactie}

Legenda van afkortingen met betrekking tot interactie

afkorting: omschrijving:

wenselijkheid concept*

hoog lagag

auton wenselijkheid van autonoon HBO

$+\quad-\quad 21$

inter wenselijkheid wan interactie tussen

HBO en beroepspraktijk

afhank

wenselijkheid wan een t.o.w. de

beroepspraktijk afhankelijk $\mathrm{HBO}$

* zie hoofdstuk 7 en de bijlagen nummer I

Voor de legenda van achtergrondkenmerken wordt verwezen naar de legenda bij eerder beschreven dimensie kwaliteit.

- Interpretatie van de analyse met betrekking tot interactie

Deze tweede landkaart van visies en kenmerken is iets minder geprononceend dan de eerste. De concepten die wij als meetinstrument gebruikten, deden ook de meningen enigszins divergeren, zoals wij ook in hoofdstuk 8 reeds konden vaststellen. $\mathrm{Er}$ is echter ook hier sprake van een drietal afzonderlijke zoneringen waarop wij nader zullen ingaan.

De drie meest relevante groepen van respondenten nemen ook op het punt van visies met betrekking tot interactie-concepten onderscheiden posities in. De arbeidsrespondenten kenmerken zich door een lage reputatie en lage inwloed. Zij zijn zowel werkzaam in profit- als non-profit organisaties, daarbij vooral in kleinere bedrijven (0-50 werknemers) en kort werkzaan. Zij komen naar voren als - relatieve - voorstanders van een HBO dat duidelijk afhankelijk is gesteld ten opzichte van de beroepspraktijk $(\mathrm{afh}+)$.

De tegengestelde visies op de concepten autonomie en afhankelijkheid van het $\mathrm{HBO}$ worden - in de sfeer van arbeid - aan weerszijden van de oorsprong weergegeven. Daarbij komt dat visies waarin een autonoon HBO (aut. +) geprefereerd worden dicht liggen bij een lage preferentie woor actief omgewingsgericht $\mathrm{HBO}$ (int. -). Maar het spiegelbeeld van deze clustering is eveneens zichtbaar. Een lage wenselijkheid voor autonoom HBO (aut. -) ligt dicht bij een hoge preferentie voor actief, omgevingsgericht $\mathrm{HBO}$ (int. + ). Het aspect afhankelijkheid (afh.) doet de meningen echter het meest divergeren en doet de groepen arbeid en onderwijs sterk uiteengaan. Ook de grootte van de bedrijven of instellingen waar mensen werken levert kennelijk verschillen in visies op.

De onderwijsrespondenten worden ten aanzien van de wisies op interactie-aspecten gekenmerkt door een relatief hoge reputatie, echter ook door een wat lagere betrokkenheid bij discussies. Expliciet is men slechts op een punt: een duidelijk t.o.v. de beroepspraktijk afhankelijk gesteld (en door de beroepspraktijk bepaald) HBO wordit afgewezen.

Respondenten uit de intermediaire sector nemen een duidelijk geïsoleerde positie in: zij worden noch door uitgesproken sociaal-structurele kenmerken noch door duidelijk geẽxpliciteerdle preferenties gekenmerkt. 
Schema 8: Resultaten correspondentie-analyse met betrekking tot structuur en arganisatie-aspecten

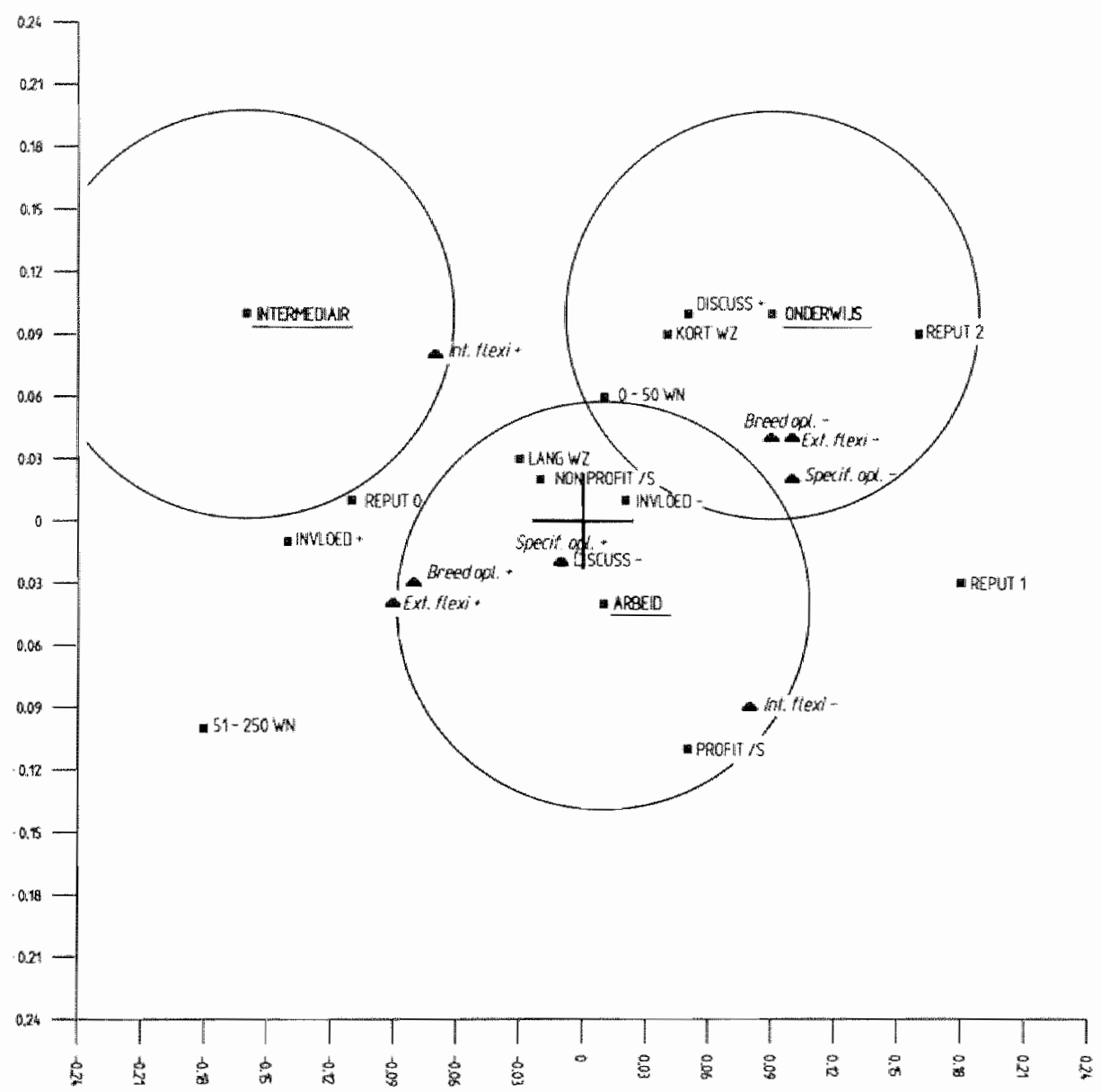


Legenda van afkortingen met betrekking tot structur en organisatie

afkorting: omschrijuing: wenselijkheid concept"
hoog laag

int flexi

wenselijkheid van interne flexibiliteit

ext hexi van $\mathrm{HBO}$ qua organisatie wenselijkheid van externe flexibiliteit

breed opl. t.o.v. de markt specif. opl. wenselijkheid van breed opleidend $\mathrm{HBO}$ wenselijkheid van specifiek opleidend HBO

$\begin{array}{lll}+ & - & 31 \\ + & - & 32 \\ + & - & 41 \\ + & - & 42\end{array}$

* zie hoofdstuk 7 en Bijlage nummer I

Voor de legenda wan achtergrondkenmerken wordt verwezen naar de legenda bij de eerder beschreven dimensie kwaliteit.

- Interpretatie van de analyse m.b.t. structuar en organisatie:

Ook bij de landkaart van posities en wisies met betrekking tot structuur- kenmerken, stellen we vast dat mensen uit de sectoren onderwijs, arbeid en intermediaire organisaties verschillende posities innemen.

De correspondentie-analyse met betrekking tot de structurconcepten laat een vrij complex beeld zien. Er is een zekere overlapping tussen de domeinen die onderwijs- en arbeidsrespondenten op de landkaart innemen. De achtergrondkenmerken vertonen het bekende beeld. De arbeidssector wordt ook op dit punt gekenmerkt door een lage invloed en een lage betrokkentreid bij discussies over beleidsontwikkeling. Arbeidsrespondenten komen voor in zowel profit als de non-profit sector. Bimnen de arbeidssector treedt zowel een hoge preferentie aan de dag voor breed als specifiek opleidend HBO. We kunnen thieruit afleiden dat zowel een breed gerichte beroepswoorbereiding als het bijbrengen van specifiek functiegerichte kwalificaties worden geprefereerd. De arbeidssector is - zo concluderen wij - vooral gecharmeerd van breed voorbereide generalisten die snel op specifieke taken inzetbaar zijn.

Toch differentieert de sector op dit punt; hoge en lage preferenties voor specifiek opleidend. HBO liggen aan weerszijden van de oorsprong; hetzelfue geldt voor de - onderscheiden - visies. van mensen uit de profit en non-profit sector.

Binnen de anderwijssector zijn een hoge reputatie en een hoge betrokkenheid bij discussie vooral typerend. De onderwijsrespondenten zijn - relatief - kort werkzaam. Zij lijken minder geporteerd voor breed opleidend HBO maar we kunnen vaststellen dat op het punt vam de imterne

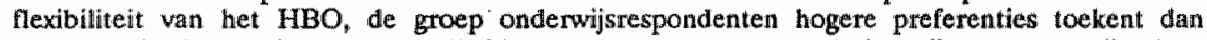
mensen uit de arbeidssector, snelheid en souplesse van verandering zijn aspecten die door onderwijsrespondenten kennelijk hoger worden gewaardeerd dan door arbeidsrespondenten. Het aspect externe flexibiliteit - opgevat als gevoeligheid voor de eisen uit en veranderingen in de beroepspraktijk - is daarentegen juist een punt dat zeer wordit toegejuicht door informanten uit de arbeidswereld, zij zijn echter minder geporteerd voor HBO dat daartoe intern-organisatorisch geêquipeerd is. Ook op dit punt treedt een zekere paradox op in de visies zoals weergegeven.

De informanten uit de intermediaire organisaties nemen ook ten aanzien van structuur-concepten een duidelijk geïsoleerde positie in en staan los van de beide andere partijen op de landkaart van visies. 


\subsubsection{Inleiding}

In deze paragraaf gaan wij in op enkele implicaties, die deze studie kan hebben voor de verhouding van hoger beroepsonderwijs en beroepspraktijk. Wij zullen daarbij drie aspecten bespreken:

- de traditionele tegenstelling tussen arbeid en onderwijs zullen wij kritisch bezien in het licht van de getrokken conclusies en de gekozen uitgangspunten

- vervolgens bespreken wij de rol van overleg. Daarna geven wij suggesties voor

- methodische/onderzoeksmatige en praktijkgeoriënteerde follow up die dit onderzoek zou kunnen krijgen.

\subsubsection{Relativering van de traditionele tegenstelling}

Het beeld van de tegenstelling tussen arbeid en onderwijs zoals dat in de literatuur en in de praktijk naar voren komt, kan worden gerelativeerd. Het onderzoek is ingegaan op het opsporen van hoofdlijnen in de betekenisgeving. De aangetroffen dimensionaliteit voor relevante subgroepen van experts, is nagenoeg gelijk gebleven. Daaruit volgt, dat zij hetzelfde conceptuele framework hanteren bij het beoordelen van aspecten van de verhouding van hoger beroepsonderwijs en beroepspraktijk. Er zijn weliswaar differentiële visies maar het aantal specifieke punten, waarop informanten tot verschillende visies komen, is minder groot dan verwacht in een benadering, die a priori uitging van fundamentele spanningsbronnen en verschillen tussen de onderscheiden sectoren.

Omdat het onderhavige onderzoek geen longitudinale studie was, kon niet worden vastgesteld of er sprake is van een objectief verdergaande ontwikkeling. Toch zijn er indicaties voor de stelling, dat met name door activiteiten van het onderwijs (transferpunten, bedrijfscontacten) de sector arbeid (scholingsinspanningen, stagecontracten etc.) en het werk van de COA's, als intermediaire organisaties, steeds meer gebruik gemaakt wordt van - effectieveinterfaces in de relatie van onderwijs en arbeid.

Ook deze ontwikkeling relativeert - in praktisch opzicht - de eerderbeschreven tegenstelling. Verwezen wordt in dit verband naar Sorge (1984) waar 
deze ontwikkeling wordt geanalyseerd in termen van een meer algemeen dialektisch proces van "kristallizatie" en "integratie" van sociale instituties.

Het lijkt ook daarom niet zinvol dat in de discussie over de relatie tussen onderwijs en arbeidsmarkt extreme stellingen worden betrokken met betrekking tot de eenzijdige aanpassing van onderwijs aan de vraag van de arbeids(markt) of omgekeerd de aanpassing van de arbeids(markt) aan het aanbod van het onderwijssysteem. Onderwijs en arbeid zijn twee, in belangrijke mate, autonome systemen met een eigen dynamiek. $\mathrm{Zij}$ beïnwloeden elkaar wederzijds en vervullen elk afzonderlijk verschillende functies. Bovendien wordt verwacht dat zij in toenemende mate onderling verweven raken (vgl. Cerych en Jallade, 1986).

In plaats van afstemming van de een op de ander moet centraal staan, dat de ontwikkelingen in beide systemen over en weer positieve effecten sorteren. De onderwijspraktijk heeft naast een toeleveringsfunctie voor de arbeidsmarkt andere functies, zoals persoonlijke ontplooïng en maatschappelijke voorbereiding.

De beroepspraktijk is niet alleen gericht op de productie van goederen en diensten maar heeft ook een educatieve functie inherent aan het opdoen van werkervaring en de kwalificerende functie van het werken in een beroep.

Ondanks het feit dat onderwijs verschillende functies vervult en dat onderwijs wel als welzijnsvoorziening wordt getypeerd, blijft de relatie met de arbeidsmarkt cruciaal. Niet alleen vanwege het functioneren van de arbeidsmarkt maar ook omdat arbeid een belangrijke factor is bij persoonlijke ontplooiing en de realisatie van maatschappelijke kansen. De relatie tussen onderwijs en arbeidsmarkt is dan ook te plaatsen tegen de achtergrond van een aantal veelvuldig gesignaleerde problemen zoals het gebrek aan arbeidsplaatsen, het voorkomen van moeilijk vervulbare vacatures, het gebrek aan overeenstemming tussen niveau en richting van het onderwijs en de specifieke vraag van de arbeidsmarkt en het gebrek aan geografische en functionele mobiliteit. Samengevat wordt dit geformuleerd als het bestaan van kwantitatieve en kwalitatieve discrepanties op de arbeidsmarkt.

Het poneren van de stelling, dat een betere coördinatie tussen onderwijsbeleid en arbeidsmarktbeleid gewenst is, is echter een al te gemakkelijke stellingname. Verder overleg plus een nadere heldere specificatie van acties en verantwoordelijkheden is gewenst (vgl. Hegelheimer, 1983).

Wij zijn deze studie gestart vanuit de assumptie dat onderwijs en arbeid twee werelden geworden waren waarvan de vertegenwoordigers elkaars taal niet meer verstaan. De data-analyse heeft aangetoond dat er differentiële visies 
zijn maar tegelijkertijd dat de denkkaders dezelfde zijn. Dit gegeven moge de tegenstelling tussen onderwijspraktijk en beroepspraktijk enigszins relativeren, tegelijkertijd legt het een extra accent op het belang van goed overleg tussen vertegenwoordigers van de beide systemen. Enkele aspecten van dit overleg schetsen wij in de volgende paragraaf.

\subsubsection{Belang en functie van gestrictureerd overleg.}

Het overleg van onderwijs en arbeid komt meer en meer in de belangstelling door de activiteiten van de COA's (Contactcentra Onderwijs-Arbeid), door de toenemende externe oriëntaties van het onderwijs zelf en door het bij het bedrijfsleven groeiende besef dat het scala van beroepsonderwijs een wezenlijke factor is bij het ontwerpen van bedrijfsbeleid en personeelsplanning.

Met De Grip (1987, p. 238) verwachten wij, dat de aansluitingsproblematiek op de arbeidsmarkt een van de voornaamste vraagstukken op sociaal-economisch terrein zal worden. Gelet op het in beweging zijn van de opstellingen van de sectoren onderwijs en arbeid (in overleg, over en weer werkend aan hun onderlinge verhouding) is het van belang kort in te gaan op de implicaties van dit onderzoek voor het overleg van beide sectoren en de intermediaire sector over de aansluitingsproblematiek en verschillen in visies daarop.

Door de oriëntatie op verschillende doelstellingen en de lage reactiesnelheid, waarmee beleidsbeslissingen effect sorteren, moeten de spanningen tussen onderwijs en arbeidsmarkt tot op zekere hoogte als "normaal" worden beschouwd.

Overleg over discrepanties tussen vraag en aanbod veronderstelt dat niet alleen het aanbod bekend is maar ook de vraag. Tevens wordt verondersteld, dat de vraag een zekere mate van stabiliteit heeft. Beide veronderstellingen zijn echter dubieus (vgl. Malglaive en Weber, 1983).

Ontwikkelingen gaan (onder andere als gevolg van technische vernieuwingen) zo snel, dat er nieuwe beroepen ontstaan en de functie-eisen voor bestaande beroepen veranderen. Behoeftenramingen zijn niet steeds betrouwbaar gebleken voor het verrichten van voorspellingen naar de toekomstige vraag naar arbeid. Naast de opgave planningstechnieken te verfijnen, is het dan ook zaak prioriteit te geven aan het formuleren van meer flexibele structuren voor effectief overleg. Dit klemt te meer waar informatie-technologie en telematica een grote vlucht zullen nemen in tal van beroepspraktijken hun intrede zullen 
doen (zie in dit verband ook Hawkridge 1983, Sociale Zaken en Werkgelegenheid 1986 alsmede Smith 1986, 1988) en op het geheel van kwalificaties "zoals gevraagd", van invloed zullen zijn. Een interessante gedachte is in dit verband in overleg te werken aan het aspect flexibiliteit, d.w.z. het vermogen van structuren om te reageren op zich veranderende situaties in het onderwijsen arbeidsbestel. Gepleit wordt voor een flexibilisering van onderwijs, opleidingen en beroepen op basis van een 'open' onderwijsplanning alsook voor dusdanige leerinhouden, die een groot toepassingsgebied bestrijken en met name op overdraagbaarheid van kennis, op mobiliteit en disponibiliteit en op permanente bereidheid tot leren gericht zijn - kortom "op kwalificaties, zoals die in het concept van permanente educatie naar voren treden" (Kraayvanger en van Onna, 1985, p. 102 e.v.).

\section{- netwerken van actores}

Ons onderzoek biedt duidelijke indicaties voor de stelling, dat er van vervlechting van mensen binnen, maar ook tussen subsystemen sprake is.

Mensen uit onderscheiden sectoren staan - zoals is aangetoond - bepaald niet diametraal tegenover elkaar in visies en verwachtingen ten aanzien van de toekomst van het HBO.

Experts die elkaar ontmoeten in interfaces of tussenschakels en zich een relatief hoge betrokkenheid bij het werk aan de verhouding toekennen, leggen andere opinies aan de dag dan mensen met een lagere betrokkenheid bij de problematiek. Uit de analyse van het materiaal blijkt, dat de toegekende expertness en de - subjectief toegekende - betrokkenheid tot subgroepen met onderling uiteenlopende visies kunnen leiden (verwezen zij naar hoofdstuk 8 van deze studie).

Verder blijkt, dat ook de mate van participatie in de discussies en beleidsontwikkeling een rol spelen. Deze participatie is niet inherent aan een positie, ook de reputatie, los van een mogelijke positie, speelt een rol. Wij pleiten ook daarom voor verdere toepassing van een netwerk-analytische aanpak in studies over de verhouding van onderwijs en arbeid. Niet alleen ter afbakening van een relevant handelingssysteeem, maar ook ten behoeve van het analyseren van de onderlinge vervlechtingen in en tussen de relevante groepen van actores op dit probleemveld die bij overleg betrokken kunnen worden (vgl. van Dijk e.a. 1987).

- de functie van intermediaire organisaties

Verwacht mag worden dat de intermediaire organisaties - of interfaceseen groeiende betekenis zullen krijgen in de verdeling van taken tussen 
regulier $\mathrm{HBO}$ en het interne opleidingscircuit van het bedrijfsleven. Wij sluiten ons in deze graag aan bij de suggestie van Van Hoof (1986, p. 26), dat "de intermediaire voorzieningen naar beide kanten toe verdere expansie- mogellikheden bezitten". Van Hoof acht een ontwikkeling denkbaar van een "tussengebied tot een tussenstelsel", dat wordt gekenmerkt door onderlinge integratie van voorzieningen en coördinatie van beleid.

Ook op dit punt kan een netwerk-analytische benadering in onderzoek en praktijk - zeker waar het gaat om de noodzaak van afstemming, overleg en verdeling - goede diensten bewijzen. Het benutten van deze interfaces als kader voor de realisatie van sectorgewijs opgezette, bedrijfstaksgewijs werkende opleidingen, uitgaande van actuele en vooral toekomstige lacunes, is zinvol. Daartoe kan verder ook behoren de uitbesteding van specifieke deeltaken in de arbeidssector aan reguliere onderwijsdocenten en - binnen het reguliere onderwijs - aan bedrijfsgebonden docenten (zie ook de aanbevelingen van de Netelcomstudie Boerwinkel, 1987 op dit punt).

\section{- sectorale/regionale aanpak}

Specifieke sectorgebonden inspanningen met een uitgesproken regionaal karakter verdienen daarbij de voorkeur boven een algemene aanpak van het probleem van de aansluiting van onderwijs en beroepspraktijk.

Gezien het feit, dat de besluitvorming rond de concrete wijze van toepassing van nieuwe mogelijkheden in de sfeer van de arbeid/beroepspraktijk veelal op bedrijfsniveau plaatswindt verdient het voorts overweging onderzoek naar de effecten, die specifiek technologische vernieuwingen op de ontwikkeling van de vraag naar bepaalde opleidingscategorieën kunnen hebben, althans gedeeltelijk te richten op dit niveau.

Op bedrijfsniveau is een duidelijk beeld te verkrijgen welke organisatorische beslissingen worden genomen inzake de wijze van toepassing van nieuwe technologie en in het bijzonder welke effecten de besluitvorming in deze heeft op het gevraagde kwalificatie-niveau van arbeid. Gegeven deze omstandigheid geven Bilderbeek en Smits (1983) de terechte suggestie een aantal kleine case-studies uit te voeren van bedrijfs(tak) specifieke maatregelen, die zijn bijvoorbeeld getroffen naar aanleiding van de introductie van CNC-machines in delen van de Nederlandse metaalindustrie. Dergelijk onderzoek zou ook goed kunnen aansluiten op soortgelijk, in het buitenland verricht onderzoek (vgl Valkenburg en Hulskes, 1983). In het verband van regionale verbijzondering moet speciale aandacht worden geschonken aan de flexibele uitbouw van scholingsmogelijkheden, aan het richten van onderwijs op de arbeidssituatie, aan verdergaande aandacht én zorg van het bedrijfsleven voor de faktor 
scholing van personeel én aan de realisatie van Open Learning Centers (Hirschberg, 1987 p. 100 e.v., De Grip 1987, p. 248, Cerych en Jallade, 1988, p. 111 e.v.).

\section{- middel-lange termijn}

Alle aanzetten tot praktische beleidsontwikkeling moeten gemaakt worden in het kader van een duidelijke middel-lange termijnvisie. De problematiek van de verhouding is in zijn totaliteit daarmee meer gediend dan met incoherente acties, gericht op korte termijn-effecten.

De middel-lange termijn-horizon kan voor alle betrokken partijen een kader bieden voor effectief onderzoek en vruchtbare interactie waarbij de gezamenlijke gerichtheid op een doel vruchtbaarder lijkt dan - uitgebreide - discussies over misverstanden en verschillen in visie op korte termijn.

- de rol van experts: thema's voor overleg

Nader overleg en samenwerking tussen experts met betrekking tot de gewenste verhouding van $\mathrm{HBO}$ en beroepspraktijk(en) zou hierbij kunnen aansluiten. Deze actie in de praktijk zou gericht kunnen zijn op de beoordeling van aspecten als:

- de concrete interactie van regulier onderwijs en bedrijven, de wijze van samenwerking in de verschillende sectoren (verwezen wordt in dit verband naar Hirschberg, 1987, p. 95 e.v. alsmede naar Craig, 1976);

- de gewenste breedte/diepgang van beroepsvoorbereiding, die mensen met een uiteenlopende achtergrond binnen het reguliere (beroeps)onderwijs bijgebracht willen zien;

- de eventueel (per subsector) gedifferentieerde functieschetsen en beroepsbeeldentoegespitst op "sociaal-normatieve" en "technisch-instrumentele" vaardigheden, benaderd en beoordeeld door experts uit de onderwijs- en de beroepspraktijk.

Door de vraagzijde - de arbeidssector - worden van het onderwijs oplossingen verwacht en vooral een kwalitatief goed geschoold en kwantitatief juist verdeeld aanbod. Toch ontbreekt het juist in de arbeidssector vaak aan betrouwbare arbeidskrachtenplanning, die een basis voor onderwijskundige prognoses en -beleid kan leveren. Dit klemt te meer, daar men ingrijpende en snelle evoluties kan vaststellen met implicaties voor omvang en kwaliteit van het aanbod (onder meer ten aanzien van nieuwe technieken, waaronder informatie-technologie, en telematica). (Zie ook Jallade en Cerych, 1987, p. 113 e.v. en CERI, 1986.) 


\subsubsection{Suggesties voor methodische en praktische follow up}

Met dit onderzoek is het handelingssysteem - binnen de provincie Limburg afgebakend en het taalveld in kaart gebracht. Wij willen enkele suggesties doen voor methodische en praktische follow-up die deze studie kan krijgen. Ten aanzien van het methodische aspect doen wij de volgende voorstellen:

- Gebleken is dat de mate van participatie in de discussies en beleidsontwikkeling een rol van betekenis spelen. Deze participatie is niet inherent aan een positie, ook de reputatie, los van een mogelijke positie, speelt duidelijk een rol.

Wij pleiten daarom voor een verdieping van de netwerk-analytische aanpak in studies, gericht op de relatie van onderwijs en arbeid. Niet alleen ter afbakening van een relevant handelingsysteem, maar ook gericht op het opsporen van onderlinge vervlechtingen en verbanden tussen en binnen de relevante groepen lijkt ons deze benadering van belang.

- Toepassing van de "Delphi-methode" kan bij voortgezet onderzoek aan het licht brengen in hoeverre experts - met een witeenlopende achtergrond - geconfronteerd met elkaars meningen, geneigd zijn hun oorspronkelijke mening te herzien. Gebruik van deze methode, in combinatie met een grote differentiatie van de aspecten betrokkenheid en invloed, kan naar onze mening zinvol zijn.

- Verdergaande studie naar het gespecificeerde belang van sociaal-normatieve vaardigheden alsmede het ontwikkelen van cognitieve hulpmiddelen om visies en verwachtingen vanuit onderscheiden sub-sectoren meer objectief in kaart te brengen is, uit het oogpunt van verdere beleidsontwikkeling eveneens gewenst.

Met betrekking tot de praktische follow-up geldt dat de resultaten van deze studie - zoals uiteengezet in hoofdstuk 1 - zouden kunnen dienen voor Delphistudies en andere technieken voor voortgezette beleidsontwikkeling. Een van de methoden, - in dat verband bruikbaar - is het scenario. Daarnaast zijn ook workshops met behulp waarvan deskundigen uit het veld - langs de weg van overleg, consultatie of informatie-uitwisseling - zich een beeld kunnen vormen van de mogelijke ontwikkelingsrichting. Deze procedures en technieken zijn geschikt voor het in groepswerband genereren van ideeën, die kunnen bijdragen aan de oplossing van het probleem. 
De uitkomsten van deze studie kunnen tot onderwerp worden gemaakt wan discussies door en met experts, te entameren in fase 2. Een globaal referentiekader voor een samenspraak van mensen uit verschillende sectoren is met de bovenbeschreven resultaten gegeven. De relevante achtergronden voor visies en samenhangen met kenmerken vam respondenten is geschetst. Verdere beleidsontwikkeling kan hierop na onderlinge samenspraak volgen. In een dergelijke fase kan (in workshops) de feitelijke confrontatie van experts met divergerende visies plaatsvinden; ontwikkeling van het denken over de verhouding van onderwijs en arbeid kan worden gebaseerd op de uitkomsten van dergelijke gedachtenwisselingen.

Zo kan bijvoorbeeld informatie-uitwisseling en overleg tussen geselecteerde deskundigen leiden tot een zekere mate van consensus over meer of minder gedetailleerde uitspraken inzake de toekomstige ontwikkeling van de vraag naar bepaalde categorieën arbeidskrachten. Daarnaast kunnen workshop-achtige procedures worden gevolgd bij de ideeën-generatie inzake experimentele vormen aan de zich wijzigende arbeidsmarktsituatie. Ook bij de selectie en begeleiding van dergelijke experimenten kunnen workshops van nut zijn (Bilderbeek en Smits, 1985, p. 87). Een scenario- of workshop-benadering kan vooral van dienst zijn ten behoeve van het structureren van discussies tijdens probleemstellende fasen in een besluitvormingsproces.

Delphi-achtig onderzoek en trend-analyses kunnen bruikbaar zijn bij het ontwikkelen van meer kwalitatieve informatie over - redelijk stabiele - lange termijn trends en het verschaffen van andere prognostische informatie (zie ook Nijssen en Brons, 1978). Aldus kan verder praktisch overleg plaatsvinden met experts die, geconfronteerd met de overeenkomsten en verschillen in visies zoals beschreven in deze studie, in onderlinge samenspraak tot bouwstenen voor verdere beleidsontwikkeling op dit terrein komen en uitspraken over de lange termijnontwikkeling een betere basis geven (zie ook de Grip, 1987 , p. 240 e.v. in dit verband).

Voor samenvattende overzichten van de daarbij te gebruiken prognostische methoden en technieken verwijzen wij naar Bilderbeek en Smits, 1985, van Doorn en van Vught, 1978, en Geurts, Hart en Caplan, 1985.

Een recente beschouwing van het denken over veranderingen in de relatie van leren in scholen en bedrijven en de integratie van werken en leren wordt geboden door Grootings e.a. (1987). 


\section{Summary}

\subsection{ESSENCE}

This study aimed at providing insight into the views on some aspects of future relations between Higher Professional Education (HBO) and professional practice. To that end the following actions have been undertaken:

- a theoretical analysis and exploration;

- a sociometric preliminary examination aimed at defining a system of actions and the appointment of the group of informants;

- a survey research.

\subsection{STARTING-POINT OF THE STUDY}

The study had its point of departure in the contrast and the much-discussed area of tension between higher professional education and professional practice; both systems cannot exist without each other; they are strongly related, but their relationship is problematic and the subject of much discussion.

The systems have essential differences in task and purpose; they have different functions and time-orientations and the discussions about the relationship of the systems are polymorphic and numerous. Judging from a great many dissertations the problem of the link-up from education to work has its own character and is of great importance.

The image of the relationship between work and education as an isolated problem seems to be provoked by the publicity in the media, trade press, organisations and interest groups.

The whole range of verifiable points of view in this field, however, is rather limited, both qualitatively and quantitatively. Moreover a lot of time and energy has been invested in the discussions about and the improvement of the link-up from education to work (also because of regulations issued by the government). It is noticeable that neither these discussions nor research with reference to the relationship between and the changeover from education to work, have significantly contributed to further specifications of views and 
expectations of experts in both systems. In particular investigations into the views of desired future relations between education and work are lacking.

\subsection{AREAS OF RESEARCH}

This study aimed at examining what education, labour-sector and intermediary organisations think of future relations between $\mathrm{HBO}$ and professional practice. In the theoretical part, which started from the supposition of a traditional contrast between the systems of educational practice and professional practice, the parties were mapped and sources of tension were identified.

This outline of ideas and expectations, concentrated on three main aspects, showed a multitude of divergent views of a polymorphic character.

Views on the quality of the output, on the relationship between education and work and on the future structure and organisation, are the main areas described and investigated in this study. The choice of these themes was made:

- on the basis of the results of previous research;

- after analysis of views on the functions of $\mathrm{HBO}$;

- after determining that approaches of the qualification-concept repeatedly imply specific outlooks on the relationship between educational practice and professional practice.

The research is restricted to the province of Limburg and is concentrated on $\mathrm{HBO}$.

\subsection{CENTRAL QUESTIONS}

The central questions applied to the specifications of the wishes, which experts in the three sectors attribute to a number of trends within three domains. The themes have been worked out in detail. Starting from the distinction between technical-instrumental and social-normative qualifications we have distinguished fourteen aspects under "quality".

The sub-sector "interaction" has been discussed starting from a number of characteristics of $\mathrm{HBO}$ and professional practice. The starting point with $\mathrm{HBO}$ is the degree of pro- or re-activity.

As far as professional practice is concerned the degree of professionalization and heterogeneity has been under discussion. The aspect "future development of the HBO-structure and organisation" has been discussed starting from the various views found in literature. Nine separate aspects of this theme have been described. Each time a number of possible developments has been formu- 
lated after studying literature and in consultation with representatives of education, labour and intermediary organisations.

\subsection{THE PARTICIPANTS IN THE RESEARCH}

The group of respondents consisted of experts in the three sectors mentioned above. A socio-metric technique (position- and reputation-method) was used to decide which persons in Limburg were to be involved in the research on the ground of their reputation. A relevant actor was identified as someone who fulfils at least one of the two conditions:

The person in question must be connected with $\mathrm{HBO}$ in his/her job (position) and/or the person in question must have a certain expert knowledge in the field of the problematical changeover from $\mathrm{HBO}$ to professional practice.

A random check of 493 informants was carried out by means of the combined use of the position- and reputation-method. The reputation, seen through the eyes of others, and the position held by people within the three sectors, were the criteria on which the random check was based.

\subsection{DATA-COMPILATION AND DATA-ANALYSIS}

The random check of 493 persons resulted in 362 reactions.

The respondents could state their degree of preference for 87 items; moreover a set of questions with regard to their own involvement in the theme of research and a series of independent variables constituted the data-set for the research.

\subsection{DIMENSIONALITY IN VIEWS AND EXPECTATIONS}

Principal component-analysis was carried out to trace the latent structure of the variables presented. A 6 -factor solution was chosen in which a further specification resulted in 13 concepts.

We came to the conclusion that the relevant actors use six quallity-aspects, as well as three interaction-aspects and four structure-aspects.

The quality-aspects fit into the distinction between technical-instrumental and social-normative qualifications; the interaction-aspects fit into the distinction autonomous and dependent $\mathrm{HBO}$. 
The theme "structure" comprises two aspects indicating the flexibility of $\mathrm{HBO}$ (internal-external) and two aspects indicating the nature of education as HBO should provide (general education versus specific training). The dimensionality was invariable for experts with different sector-backgrounds and different educational backgrounds.

Accordingly the experts, who were consulted with regard to the facets of the changeover from HBO to professional practice, judge from the same "conceptual framework". Remarkable differences in the main lines on which judgement is based, could not be found.

\subsection{SPECIFIED DIFFERENCES IN VIEW}

Numerous dissertations on the changeover from education to work, suggest a gap between THE labour-system and THE education.

From this research it appears that the problem should be put in perspective and that the differences are not as fundamental as they frequently seem to be. Differences in view and expectations only arise in subsectors. The respondents who were consulted use the same conceptual framework, and the number of issues, in which differences in view were found, was limited.

In spite of the existence of identical conceptual framework, differential views could be seen. Thirteen concepts were used as measuring-instruments with which the views and differences in view were mapped. Differences could be explained as follows:

- The sectors in which respondents work. Respondents in the labour-sector and respondents in the educational sector differ significantly in their views on a certain number of points, both on the aspects of quality and also as far as interaction is concerned. In particular the attribution or non-attribution of a primate to the professional practice resulted in divergent opinions.

- The educational background (calculated by means of the triad: social-pedagogical/technical/clerical-judicial) accounted for many differences in view.

- The aspects accounting for the most frequent and the greatest difference in view, were related to the influence and involvement, which respondents ascribed to themselves in decision-making processes concerning the future of $\mathrm{HBO}$.

From the order based on the scale-averages of the thirteen aspects, it appeared that interaction between education and professional practice in terms of an open dialogue is considered to be the most desirable solution. Autonomous $\mathrm{HBO}$ is regarded to be less desirable. 
The quality-aspects "organisation/planning" and "independence" are also at the top of the list of priorities.

The communicative skills, as a quality-aspect are also given high preference. The aspects of structure submitted, both the internal and external flexibility and the general education versus specific training in HBO is regarded less desirable. The connections between the various aspects of judgement and the social-structural background-characteristics were also examined.

On the whole it appeared that there were few connections with these socialstructural background-characteristics. Taking this into account along with the statement that certain relations only exist from the point of view of active participation in the discussions concerning policy, we may assume that we are dealing with competent people.

The experts differ in opinion on certain aspects, and they certainly don't agree on all the issues. Of the six quality-aspects it appears that "organisation/planning" and "management-techniques" were issues leading to divergent opinions.

Of the interaction-aspects it turns out that the independence of HBO results in a diversity of opinions. The "experts" are fairly in agreement on the aspects of structure. The "non-experts" differ in opinion about internal flexibility.

Finally the main conclusions have been summarized and classified according to the viewpoint originally chosen viz. "quality-interaction-structure".

Subsequently more attention was given to the traditional contrast between work and education. Moreover some implications for consultation between education and work were outlined and suggestions for follow-up of this research were formulated.

With this research we have tried to give the initial impetus to an inventory of views on three themes in the discussions on the future relationship between Higher Professional Education and professional practice in the province of Limburg. 


\section{Referenties}

Aarts, J.F.M.C., Deen, N., Giesbers, J.H.G.I., Onderwijs in Nederland, Groningen, 1983

Albach, H., Betriebswirtschaftliche Hochschulausbildung, Wiesbaden, 1982

Albeda, W., in: SMO Informatief, Werk, Loon, Mobiliteit, nr. 21, 1978 pp. 5-22

Albert, H., Rationaliteit in wetenschap en samenleving, Alphen a/d Rijn, 1976

Albinski, M., Survey research, Utrecht/Antwerpen, 1974

Albrecht, G., Hochschulabsolventen im Beruf, Bielefeld, 1979

Bair, J. en Mancuso L., The office systems cycle, Palo-Alto, 1985

Beck, W., Bolte, K.M., Brater, M, Bildungsreform und Berufsreform, LAB Mitteillungen 1976, Nürnberg

Bevers, J.A.A.M., Bouhuijs, P.A.J. en Gobits, R., Een staalkaart van veranderingen in het hoger onderwijs, 's-Gravenhage, 1981

Bickeboller-Kubiak, $H$., Strukturprobleme zwischen Bildungs- und beschäftigungssystem, in: Erziehungswissenschaft und Beruf, 3i (1983) or. 1, p. 3.

Bilderbeek, D. en Smits G., Methoden en Technieken voor onderzoek van de relatie tussen onderwijs en arbeid, Delft, 1983

Boerwinkel, J.G. e.a. Eindrapport van de aansluitingsproblematiek tussen Hoger Onderwijs en de telecommunicatiesector, Enschede, 1987. (Netelcom studie)

Boon, J., Kwalificatie-onderzoek en arbeidsmarkttheorie, paper 4de Onderwijssociologische Conferentie, Amsterdam 1979

Bruggen, van, J., Leren, school en onderwijzen, Stichting Ontwikkeling Leerplan, Enschede, 1983

CERI, (Centre for Educational Research and Innovation) New information Technologies, A challenge for education, Paris, 1986

Cerych, L., Jallade, J.P., The coming technological revolution in education, Paris, 1988

Creemers, B., (red), De kwaliteit van het onderwijs, Groningen, 1983

Craig, R.L., Training and Development Handbook, A Guide to Human Resource Development, New York, 1976

Doorn, van, J. en Vught, van, F., Planning, methoden en technieken voor beleidsondersteuning, Amsterdam, 1978

Dyk, van, C.A.M., Akkermans M.J.W.M. en Hövels, B.W.M., Sociale partners en het beroepsonderwijs in Nederland, Berlijn, 1987

Eide, K., Scenario Building and Qualitative Forecasting in Education, Parijs, 1983 
Eheim, HD., Grünewald, B., Meifort U., Dimensionen einer Qualifikationsforschung für Berufsbildungspraxis und -politik; Einige Thesen; in: Berufsbildung in Wissenschafi und Praxis, 11 (1982) nr. 6, p. 8

ETIL, Knelpunten tussen onderwijs en arbeidsmarkt, Maastricht, 1985

ETIL, Kwalitatieve knelpunten bij schoolverlaters op de arbeidsmarkt, Maastricht, 1986

Felling, A.J.A., Lokale macht en netwerken, Alphen a/d Rijn, 1974a

Felling, A.J.A., Sociaal netwerk analyse, Alphen a/d Rijn, 1974b

Felling, A.J.A., Schreuder, O., Peters, J., Burgerlijk en onburgerlijk Nederland, Deventer, 1983

Frederix, L.L.M. Onderwijs en Arbeidsmarkt, Nijmegen, 1978

Gadourek, I., Sociologische onderzoekstechnieken, Deventer, herziene druk 1976 Gageldonk, D.J. van, et.al., HBO in verscheidenheid en samenhang, Den Haag, 1983

Geurts, J.L.A., Hart, S.L., en Caplan, N.S., Decision techniques and social research, in: Human Systems Management, 5e jaargang (1985), p. 252 e.v. Gordon, M.S. (ed.), Higher Education and the Labor Market, New York, 1974 Gorzka, G., Forschung über Hochschule und Beruf, Arbeitsbericht 1978-1984

Werkstattberichte, Band 13, (WZBHF/Kassel) 1985

Gravendeel, A.C., en Krijnen, G., De aansluitingsproblematiek onderwijsberoepspraktijk, in: ESB (1975), p. 287

Grip, A. de, Onderwijs en arbeidsmarkt, Scholingsdiscrepanties, Amsterdam, 1987

Grootings, P. et.al., Work and Learning, Maastricht, 1987, (Work and Society no. 8)

Hamaker, H.G., Sociologie van arbeid en beroep in: Rademaker, L. (red), Sociologische encyclopedie, deel 1, Utrecht/Antwerpen, 1978

Hawkridge, D., New Information Technology in Education, London 1983

HBO Raad, Versterking door samenwerking, Beleidsnota, 's-Gravenhage, 1983 Hegelheimer, A., Beruf und Bildung: Perspektiven für die Zukunft, in: Wirtschaft und Berufserziehung, 53 (1983) nr. 5, p. 138

HOOP Hoger Onderwijs en OnderzoeksPlan 1988, Zoetermeer, 1988

HIA (Hoger Inst. Arbeid) van de K.U Leuven, De aansluiting tussen onderwijs arbeid, Leuven, 1986

Hill, J., Scharf, D.E., Between two worlds, aspects of the transition from school to work, Richmond, 1976

Hirschberg, D., Partnerships for cost-effective continuing education, in: Grootings, P. et.al., Work and lerning, Maastricht, 1987 (Work + Society, nr. 8)

Hoger Onderwijs: Autonomie en kwaliteit, Den Haag, 1985 (HOAK-nota) 
Hoof, J.J., van, Dronkers, J., Onderwijs en Arbeidsmarkt, Deventer, 1980

Hoof, J.J., van, Interfaces en tussenschakels in: Tijdschrift voor Arbeidsvraagstukken, 2e jaargang (1986) nr. 2, p. 334

Hoppock, R., Occupational Information, New York, 1967

Hövels, B., Peschar, J., Programmering van onderzoek naar onderwijs en arbeidssituatie, concept eindverslag I.T.S., Nijmegen, 1985

Hövels, B.y Onderwijs en Arbeid, Een omgevingsverkenning van onderwijs en arbeid I.T.S., Nijmegen, 1984

Huber, L., De toekomst van het Hoger Onderwijs, in: Tijdschrift voor Hoger Onderwijs, 1985 (1)

Husèn, T., Alternative educational forces, Parijs, 1970

Idenburg, Ph.J., Theorie van het onderwijsbeleid, Groningen, 1971

Iersel, J. van, Ontwikkelingen in het beleid m.b.t. de aansluiting tussen onderwijs en arbeid, in: Tijdschrift voor Arbeidsvraagstukken, (1986), wr.1, p.52 Interaction, The, between education and produktive work, (EDI) 56 (1982), nr. 225 , p. 5

Jallade, J. en Cerych, L, Selected Issues in Assesment and certification, in: Grootings, P. et.al., Work and Society, no. 8, Maastricht, 1987

Kamerstuk 19454: Hoger onderwijs, technologie en marktsector. Nota van de

Minister van Onderwijs en Wetenschappen en de Minister van Economische

Zaken aan de Tweede Kamer, Den Haag, 1985

Kemenadle, J. van, (red), Onderwijs, beleid en bestel, Groningen, 1981

Kemenade, J. van, Als de smalle weegbree bloeit, Opstellen over onderwijsbeleid, Amsterdam, 1979

Keulenaar, de, Th., Penders, J., Geurts, J., Onderwijs en arbeid, Lisse, 1984 Knip, J.L., Organisatiestudies in het onderwijs: organisatorische differentiatie en integratie in een hogere beroepsopleiding, Utrecht, 1981 (dissertatie) Kohli, M., Studium und berufliche Laufbahn, Stuttgart, 1973

Kühlewind, G., Tessaring, M., Argumente für und gegen eine beschäftigungsorientierte Bildungspolitik, Göttingen, 1975

Kraaijvanger, G. en Onna, van, B., Arbeid en leren. Bijdragen tot de volwasseneducatie, Baarn, 1985

Laayendecker, $L$., Orde, verandering, ongelijkheid: een inleiding in de geschiedenis van de sociologie, Meppel/Amsterdam, 1981

Lempert, W., "Arbeitsteilung, Bildungsprozesse, Sozialisation", opgenomen in: Deutsche Berufs- und Fachschule 75 Bd, Heft 3/1979, p. 112

Mc Daniel O.C., Naar de toekomst van het hoger onderwijs, Amsterdam, 1984 Mc Quitty L.L., Elementary Linkage Analysis for isolating orthogonal and obligue types and typical relevancies, in: Educational and Psychological Measurement, 17e jrg. (1957) 
Malglaive, G., Weber, A., Ecole et Entreprise; Interet et limites de l'alternance en pedagogie, in: Revue Française de Pedagogie, 1983, nr. 62, p. 51

Mertens, D., Schlüsselkwalificationen: Thesen zur Schulung für eine moderne Industriegesellschaft, in: Mitt./AB 7 (1974), p. 36-43

Mertens, F.J.M., Stages in een beroepsopleiding, het praktijkjaar van het hoger technisch onderwijs, Amsterdam, 1981

Ministerie van Onderwijs en Wetenschappen, Hoger Onderwijs en Onderzoekplan 1988, Zoetermeer 1988

Naisbitt, J., Megatrends: Ten new directions transforming our lives, New York, 1983

Nunnally, J.C., Psychometric Theory, New York, 1978

Nijssen, J.B., Brons, R., Onderwijs en arbeidsmarkt: een evaluatie van prognoses, afd. Planning KU Nijmegen, Nijmegen, 1978

Parkes, D., Sellin, B., Tessaring, M., Education/Training in Labour Market Policy, 1986, Den Haag

Polak, L.J., Kwalificeert het Hoger Onderwijs adequaat?, in: Tijdschrift voor Hoger Onderwijs (1), 1983, nr. 2

Polak, L.J., Onderwijsvoorzieningen door Samenwerking, Maastricht, 1981

Ritzen, J., Wat is onderwijs ons waard? Een sociaal economische benadering, Groningen, 1983

Rogers, E.M. en Kincaid, D.L., Communication networks, towards a new paradigm for research, New York, 1981

Schleucher, A. en Maskow, J., Darstellung und Analyse des Begriffes Qualifikation in: Zeitschrift für Arbeitswissenschaft 37 (1983) nr. 3 p. 138

Schouten, J., (red), Ach meneer, ze kunnen tegenwoordig geen hamer meer vasthouden, SMO Scheveningen, 1977

Shane, H.G., Tabler M.B., Probable Developments in the Social Sciences and their consequences for Educational content, Paris, 1980

Smith, J., People and Technology (Conference Report), Proceedings of the conference held in London (november 1986) as part of the Eurotecnet programme, London 1986

Smith, J., Moving Forward, The education and training of young people in new information-technologies, Maastricht, 1988

Sociaal Economische Raad, Voorstudie over de relatie onderwijs-arbeidsmarkt, 's-Gravenhage, 1981, (SER-nota)

Sociale Zaken en werkgelegenheid, Ministerie van, Studie: Informatie technologie en werkgelegenheid, 1986

Sorge, A., Informationstechnik und Arbeit im sozialen Prozess, Frankfurt, 1984 Swanborn, P.G., Steekproef in: Rademaker, L. (red.), Sociologische Encyclopedie deel III, Utrecht/Antwerpen, 1978 
Teichler, U., Hartung, D., Nuthmann, R, Higher Education and the needs of society, New York, 1980

Toffler, A., De derde golf, Utrecht/Antwerpen, 1982

Vervoort, C.E., Onderwijs en maatschappij, Nijmegen, 1975

Valkenburg, F. en Hulskes, A., Kwalificatie-ontwikkeling tijdens de beroepsloopbaan, Tilburg, 1983

Vlaskamp, F., Hövels, B., Onderwijs en arbeidsmarkt: aansluitingsonderzoek, ITS Nijmegen, 1980

Wassink, J.G.J., Braam, G.P.A., De reputatie-methode in het lokale machtsonderzoek, in: Mens \& Maatschappij, nr. 3, jrg. 59, 1984, pp 251-268

Weisshuhn, G., Sozioökonomische Analyse von Bildungs- und Ausbildungsaktivitäten, Berlin, 1977

Wentink, T., Zanders, A., Kantoren in actie, Een onderzoek naar kantoorautomatisering en de gevolgen voor kantoorarbeid en kantoororganisatie, Deventer, 1985

Wesselingh, A.A., Sociologie van het onderwijs, in Rademaker, T., (red), Toegepaste sociologie, deel 1, Utrecht/Antwerpen, 1981a, pp 211-239

Wesselingh, A.A., Onderwijs en Maatschappelijke ongelijkheid in: Rademaker, L., (red), Sociale kaart van Nederland, deel III, Utrecht/Antwerpen, 1981b, pp. 225-245

Wielemans, W., Opvoeding en onderwijs onder maatschappelijke druk, Leuven/ Amersfoort, 1983

Wierik, J. te, Contactcentra Onderwijs Arbeid, een symphonie van communicatie en overleg in de Wagner Ouverture, in: Interaktie, p. 110

Wieringen, A.M.L. van, De identiteit van het hoger beroepsonderwijs, Groningen, 1976

Wieringen, A.M.L. van, Alleen zijn is erger (over de dynamiek van de betrekkingen tussen onderwijs 'en arbeid), Amsterdam, 1984, in: Branger, J., Dodde, N. en Wielemans, W., Onderwijsbeleid in Nederland, Leuven, 1984 Wieringen, A.M.L. van, (ed.), Management van onderwijsinstellingen, Groningen, 1986 


\section{Curriculum vitae}

De auteur van dil proefschrift werd in 1948 geboren te Klimmen. Na de MULOopleiding trad hij in 1964 in dienst bij het Ministerie van Sociale Zaken en was daar werkzaam tot 1980 , laatstelijk als Directeur van het Gewestelijk Arbeidsbureau te Venlo. Hij behaalde het diploma Middelbare Sociale Arbeid (1968), de akten M.O. Pedagogiek A (1971) en B (1973), studeerde in 1978 bij de Katholieke Universiteit te Nijmegen af in de Sociale Pedagogiek en Andragogiek en doorliep diverse cursussen voor personeels- en organisatiebeleid binnen de Rijksdienst.

Van 1980 tot 1987 was hij werkzaam als Directeur van de Provinciale Raad voor het Jeugdbeleid in Limburg, binnen de afdeling Welzijn en Volksgezondheid van de Provinciale Griffie te Maastricht en laatstelijk als plaatsvervangend Chef van het Kabinet van de Commissaris der Koningin. Voorts was hij, in de periode 1974 - 1983, werkzaam als part-time docent in het MSPO en HSPO en als docent verbonden aan het Limburgs Universitair Centrum te Diepenbeek (B) ten behoeve van de Masteropleiding Welzijnswerk aldaar.

Sedert 1987 werkt hij bij het raadgevend ingenieursbureau "Intercai B.V." te Geleen en is daar belast met de ontwikkeling en realisatie van opleidingen op het vlak van Telematica-beleid.

De belangstelling voor de verhouding van onderwijs en arbeid, respectievelijk het $\mathrm{HBO}$ en de beroepspraktijk, stamt uit de eigen beroepspraktijk bij Arbeidswoorziening, zijn ervaringen als beroepskracht in het onderwijs, de betrokkenheid bij het C.O.A. Limburg, waarvan hij voorzitter was, alsook wit de in de opleidingen gekozen differentiaties. 



\section{Bijlagen}

Nummer Omschrijving

I

Operationalisatie en schaalconstructie (blad $1 \mathrm{t} / \mathrm{m}$ blad 5)

II

Totaal aantal benaderde adressen per sector tijdens het vooronderzoek vergeleken met absolute en relatieve response

III

Scores op betrokkenheid bij invloed, discussie en beleidsontwikkeling, gespecificeerd naar positie (blad 1) en ingraad (blad 2)

IV Factorladingen van de componenten en de concepten (blad $1 \mathrm{t} / \mathrm{m}$ 3) en de correlatiematrix van additieve schalen (blad 4)

V

Sociaal-structurele achtergrondkenmerken en hun categorieën (blad 1 en 2)

VI Significantie en relevantie van de verbanden tussen sociaalstructurele achtergrondkenmerken en de niet in geconstrueerde schalen opgenomen items

VII Significantie en relevantie van de verbanden tussen de sociaalstructurele achtergrondkenmerken en de geconstrueerde additieve schalen

VIII Matrices van $x$-scores en ry-punten, resp. $y$-scores en kolompunten inzake ontvouwingsanalyse met betrekking tot kwaliteit (blad 1), interactie (blad 2) en structuur (blad 3)

IX Schematisch overzicht van de vragenlijst, zoals gebruikt bij het survey-onderzoek

$\mathrm{X}$ Overzicht van informanten gespecificeerd naar sectoren en subsectoren

XI Lijst van afkortingen 
OPERATIONALISATIE EN SCHAALCONSTRUCTIE

Toelichting: het samenvattend overzicht is verdeeld over vier pagina"s (pp. 2 - 5). In de linkerkolom staan de items gegroepeerd volgens het theoretisch concept (zie hoofdstuk 6). Een item behorend tot een bepaalde schaal, wordt aangegeven met een kruisje in de betreffende kolommen. De kolomnummers verwijzen naar de componenten en hun subdimensies (zie hoofdstuk 7), waarvan wij de benamingen hieronder weergeven.

Componenten en hun subdimensies.

Nummer Naam

1

11

12

13

14

2

21

22

23

3

31

32

4

41

42

5

51

52

6
Sociaal-normatieve kwalificaties

- Zelfstandigheid

- Communicatieve vaardigheden

- Samenwerking

- Organisatie \& planning

Interactie $\mathrm{HBO}$ en beroepspraktijk

- Autonoom HBO

- Aard interactie

- Afhankelijk HBO

Flexibiliteit van het $\mathrm{HBO}$

- Interne flexibiliteit

- Externe flexibiliteit

Algemene versus specifieke $\mathrm{HBO}$ opleiding

- Breed opleidend HBO

- Specifiek opleidend HBO

Technisch-instrumentele kwalificaties

- Leidinggeven

- Managementtechnieken

Wetgeving

Uit: Niet in schalen opgenomen items (zie ook bijlage $V$ ). 
Bijlage 1, blad 2

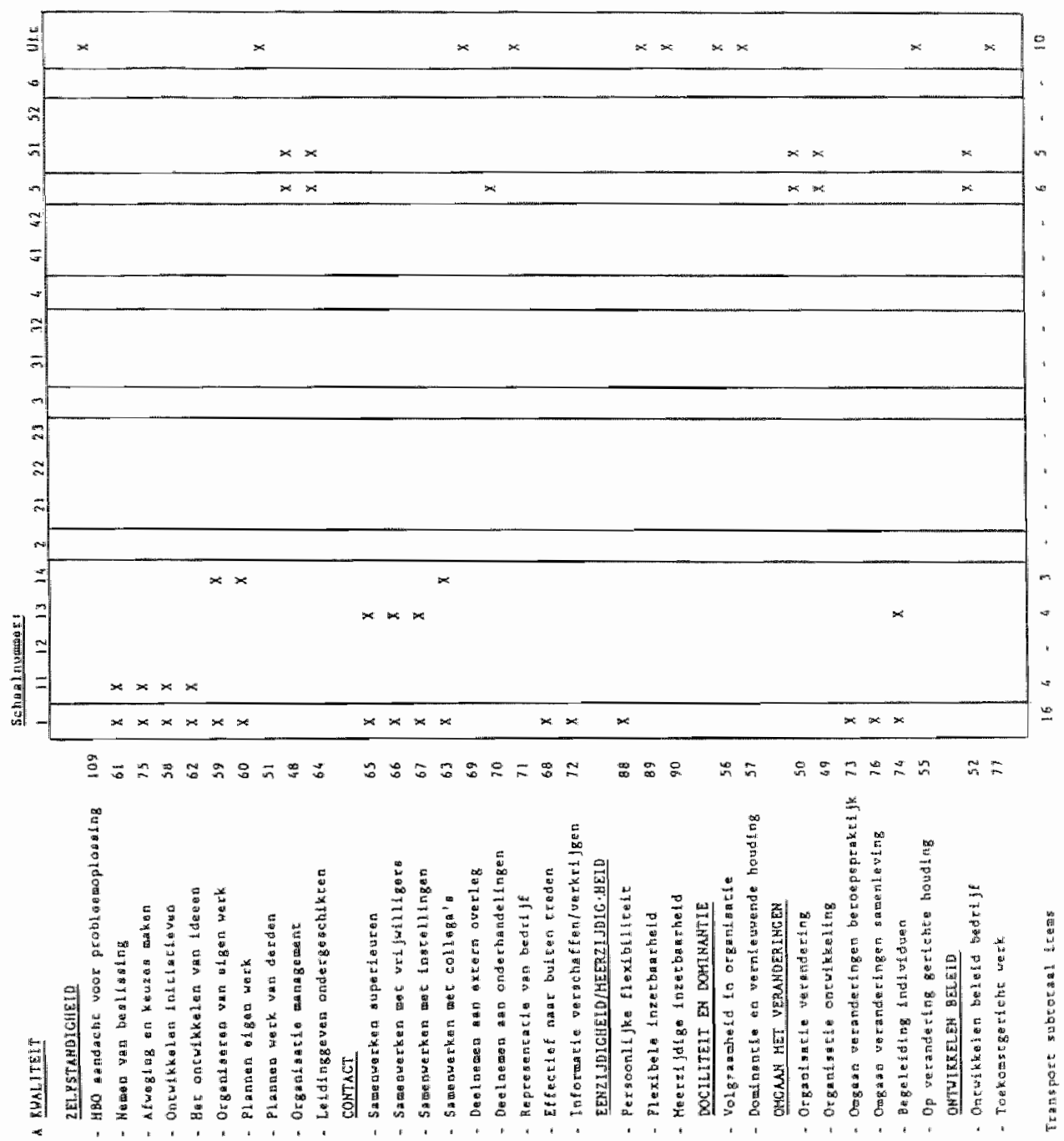


Bijlage I, blad 3

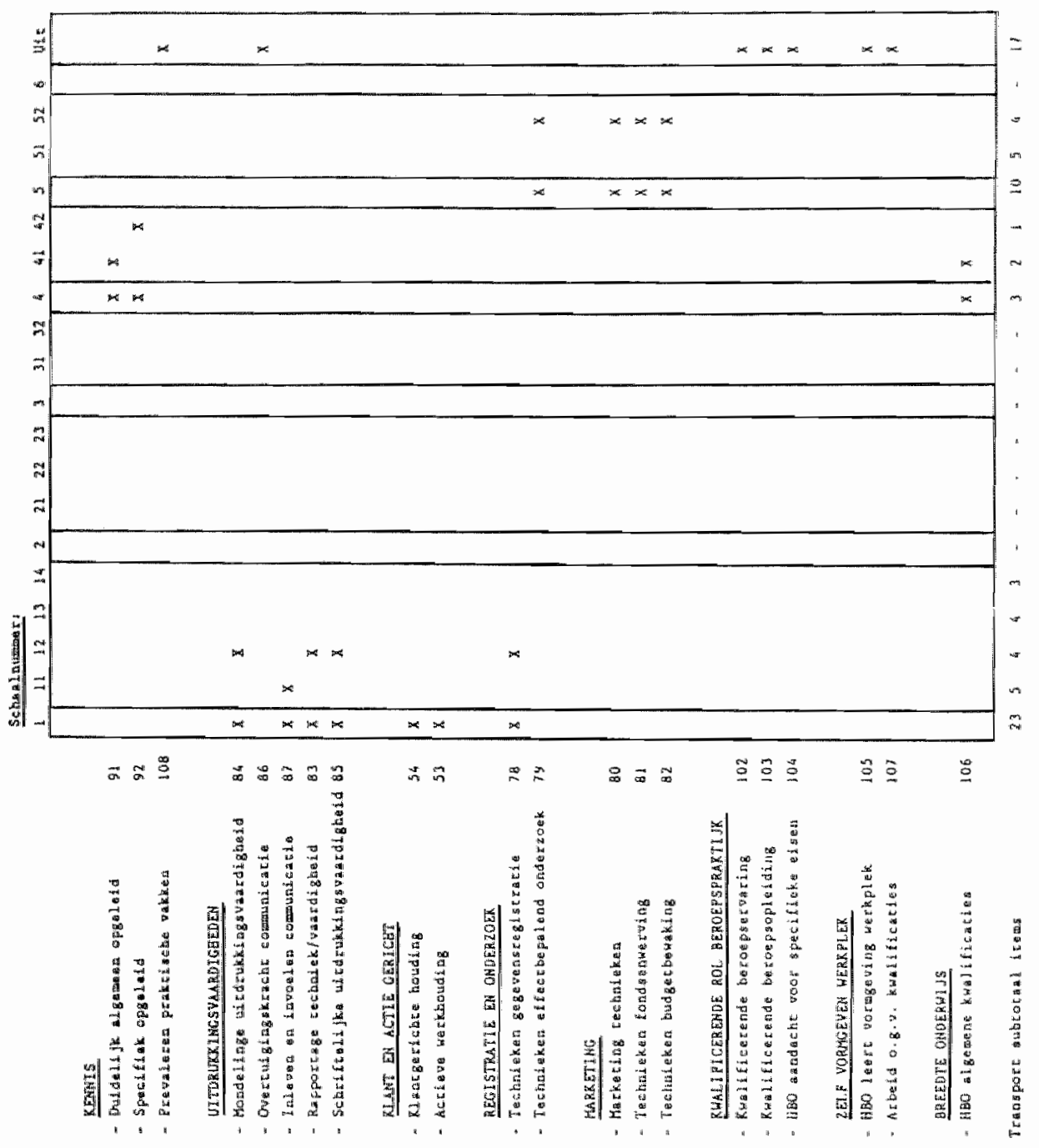


Bijlage $I_{s}$ blad 4
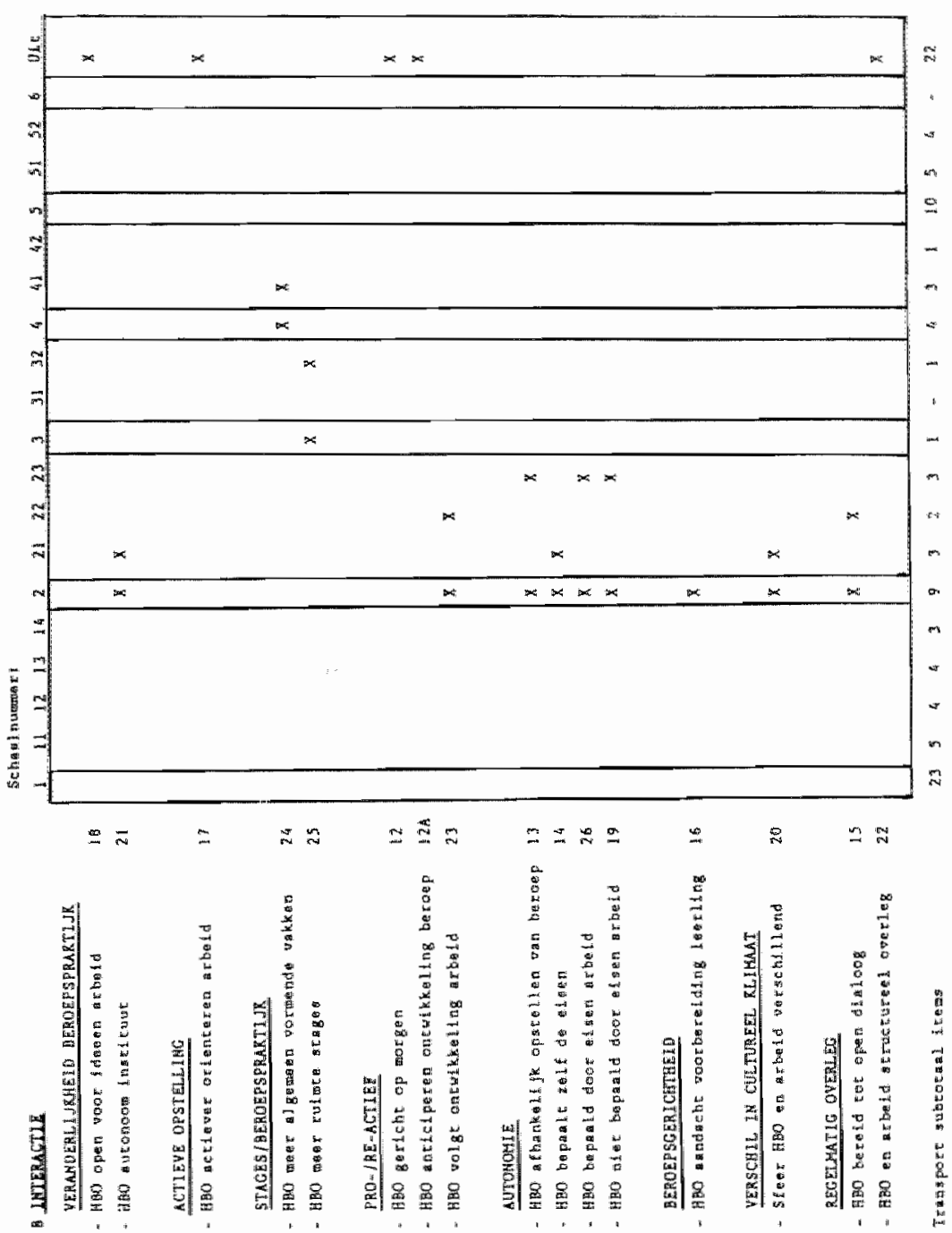
Bijlage 1, blad 5

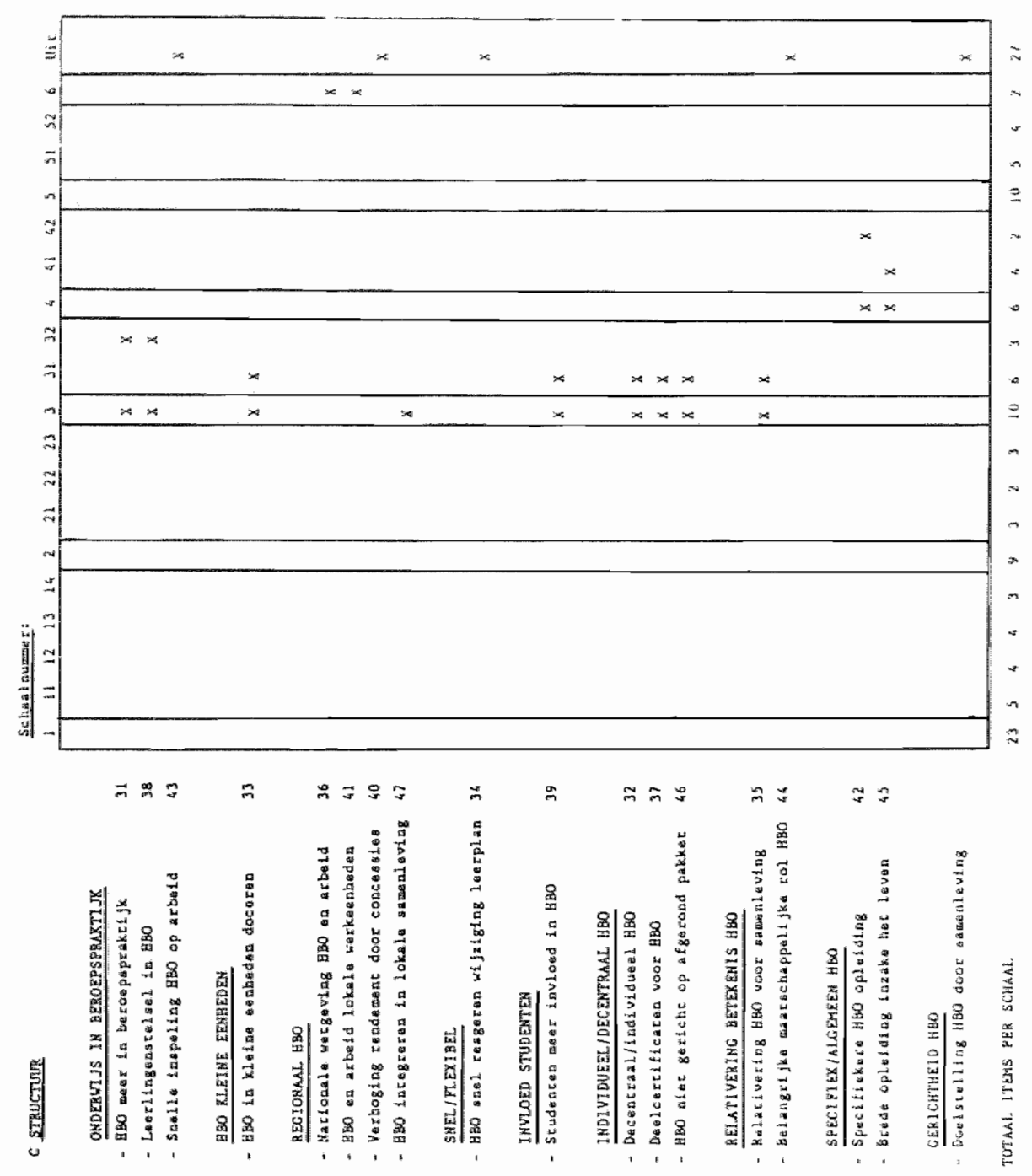


Bijlage $\mathrm{I}_{\mathrm{s}}$ blad 1

TOTAAL AANTAL BENADERDE ADRESSEN PER SECTOR TIJDENS HET VOORONDERZOEK VERGELEKEN MET DE ABSOLUTE EN RELATIEVE RESPONSE

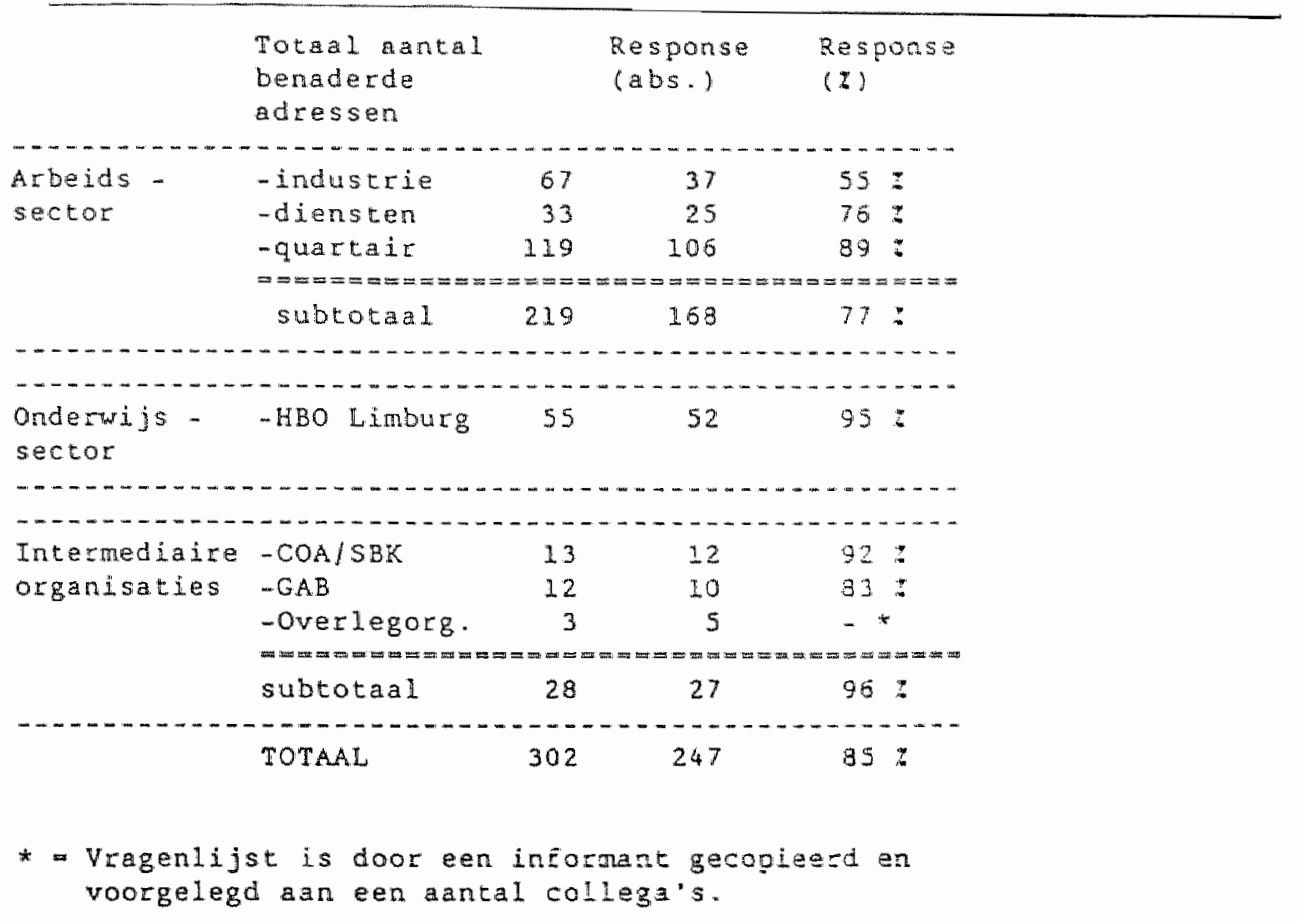


Bijlage III, blad 1

\section{BETROKKENHEID}

Tabel IIIa :Beslissende invloed(v9), betrokkenheid discussie (V10) en betrokkenheid beleidsontwikkeling (V11) gespecificeerd nat positie (V7) (percentages tussen haakjes).

Vo Beslissende invload

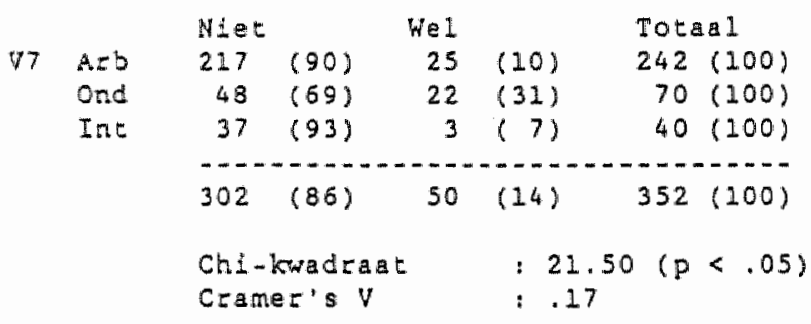

\section{V10 Betrokkenheid discussie}

\begin{tabular}{|c|c|c|c|c|c|c|}
\hline & \multirow{2}{*}{$\begin{array}{l}\text { Miet } \\
182\end{array}$} & \multicolumn{3}{|c|}{ Wel } & \multicolumn{2}{|c|}{ Total } \\
\hline \multirow{3}{*}{$\begin{array}{l}\text { Arb } \\
\text { Ond } \\
\text { Int }\end{array}$} & & (75) & 61 & (25) & 243 & $(100)$ \\
\hline & 19 & (27) & 51 & (73) & 70 & $(100)$ \\
\hline & 31 & $(78)$ & 9 & (22) & 40 & $(100)$ \\
\hline & 232 & $(66)$ & 121 & (34) & 353 & $(100)$ \\
\hline & $\begin{array}{l}\text { Chi- } \\
\text { Cram }\end{array}$ & $\begin{array}{l}\text { cwadr } \\
\text { ar's }\end{array}$ & & $\begin{array}{l}* 5 \\
* .2\end{array}$ & $91 P$ & $(.05)$ \\
\hline
\end{tabular}

\section{V11 Betrokkenheid beleidsontwikkeling}

$$
\begin{aligned}
& \text { Hiet Wel Total } \\
& V 7 \text { Arb } 224 \text { (93) } 17 \quad(7) \quad 241(100) \\
& \text { ond } 35 \quad(50) \quad 36 \quad(50) \quad 70(100) \\
& \text { Int } 39 \text { (95) } 2 \text { (5) } 41(100) \\
& 298 \text { (84) } 55(16) \quad 353(100) \\
& \text { Chi-kwadrast }: 83.48(\mathrm{p}<.05) \\
& \text { Cramer's } V \quad: .34
\end{aligned}
$$

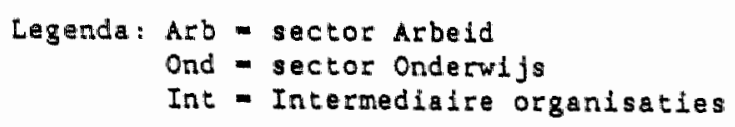


Bijlage III, blad 2

Tabel IIIb : Beslissende invloed(V9), betrokkenheid discussie (V10) en betrokkenheid beleidsontwikkeling (V11) gespecificeetc! naar ingraad (ID) (percentages tussen hakjes).

\section{V9 Beslisserde lnvloed}

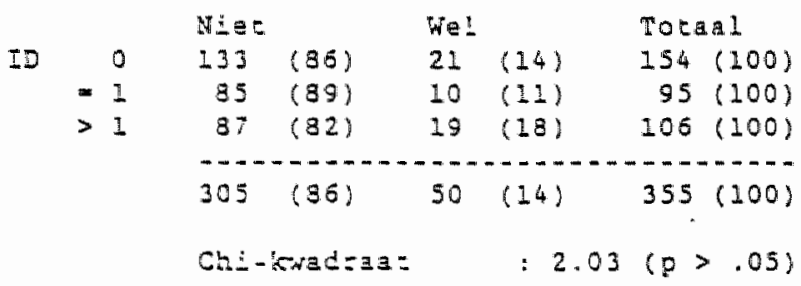

\section{Vio Bezrokkenheid discussie}

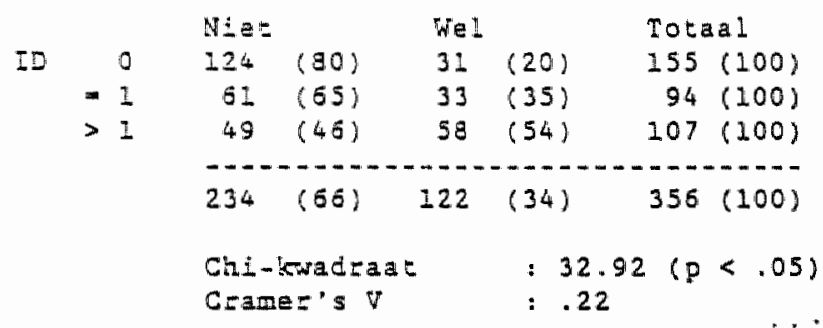

V1 Betcokkenheid beleidsontwikkeling

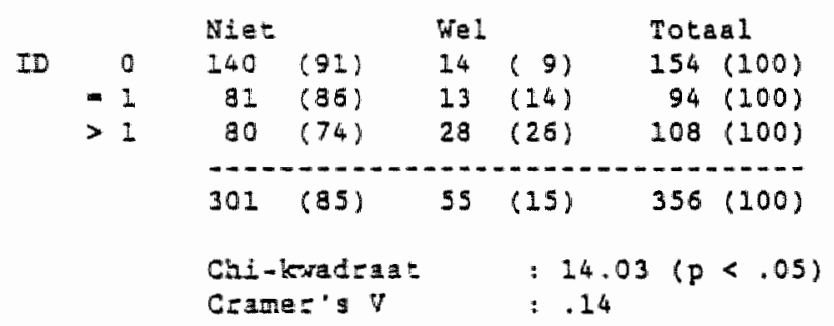


Bijlage IV, blad 1

\section{FACTORLADINGEN VAN DE COMPONENTEN EN DE CONCEPTEN}

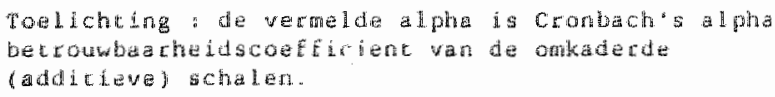

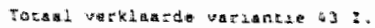


Bijlage IV, blad 2

A. Concepten "Sociaal-normatieve kwalificaties"

\begin{tabular}{|c|c|c|c|c|}
\hline & CONC 11 & CONG 12 & CONC 13 & conc \\
\hline 62 & .81 & .01 & -.09 & -.16 \\
\hline 58 & .75 & .01 & -.11 & -.27 \\
\hline $6 I$ & .75 & -.03 & .05 & -.09 \\
\hline 75 & .71 & -.06 & .16 & .20 \\
\hline 87 & .42 & -.21 & .31 & .19 \\
\hline 85 & .01 & -.93 & -.07 & .02 \\
\hline 8.4 & .10 & -.85 & -.05 & .06 \\
\hline 83 & -.01 & -.84 & -.07 & -.05 \\
\hline 78 & -.13 & -.45 & .17 & -.23 \\
\hline 66 & -.12 & .05 & .89 & -.03 \\
\hline 67 & .09 & .05 & .77 & -.07 \\
\hline 65 & .02 & -.01 & .66 & -.18 \\
\hline 74 & .35 & -.23 & .47 & .31 \\
\hline 59 & .19 & -.10 & .16 & -.72 \\
\hline 50 & .20 & -.09 & .26 & $=.66$ \\
\hline 63 & .17 & -.15 & .07 & -.52 \\
\hline-3 & $-x-n$ & $-\cdots$ & $--n-\cdots$ & $\cdots$ \\
\hline Eigenwaaarde & 6.20 & 1.50 & 1.35 & 1.21 \\
\hline Alpha & .79 & .74 & .75 & .76 \\
\hline
\end{tabular}

B. Concepten "Interactie $\mathrm{HBO}$ en beroepspraktijk"

\begin{tabular}{lccc}
\multicolumn{1}{c}{ CONC 21} & CONC 22 & CONC 23 \\
21 & .87 & .06 & -.01 \\
20 & .75 & -.14 & .08 \\
14 & .58 & -.03 & -.15 \\
23 & .04 & .83 & .11 \\
15 & -.17 & .77 & -.04 \\
13 & .03 & .02 & .77 \\
26 & .07 & .26 & .75 \\
19 & .24 & .21 & -.68 \\
\hline Eigenwarde & 2.82 & 1.18 & 1.00 \\
Alpha & .64 & .48 & .64 \\
Total verklagrde variantie 62.5 & 7 \\
\hline
\end{tabular}


Bijlage IV, blad 3

C. Concepten "Elexibliteit wan het HBO"

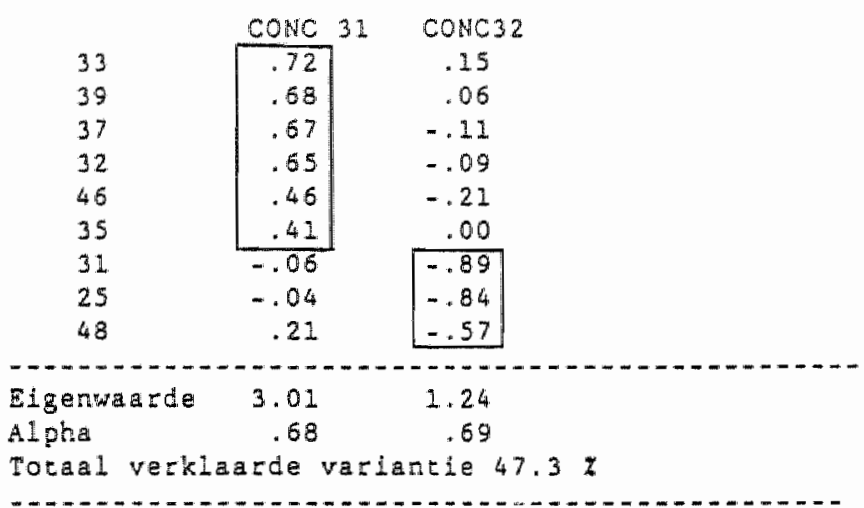

D. Concepten 'Algemeen versus specifleke HBO opleiding "

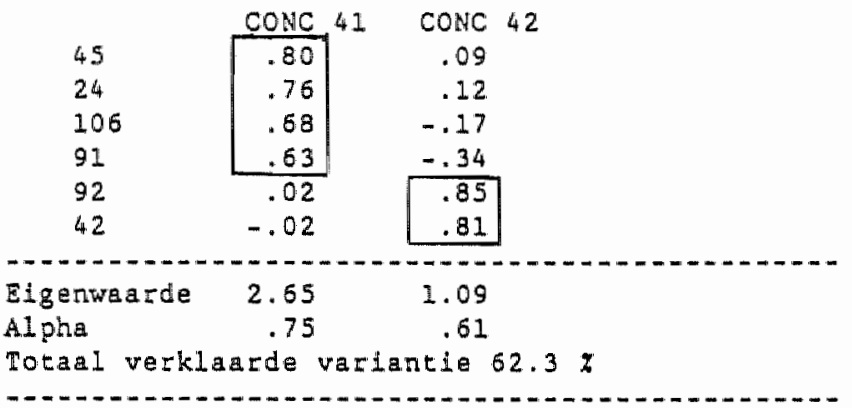

E. Concapten "Techoisch-lnstrumentele kwaliflcaties"

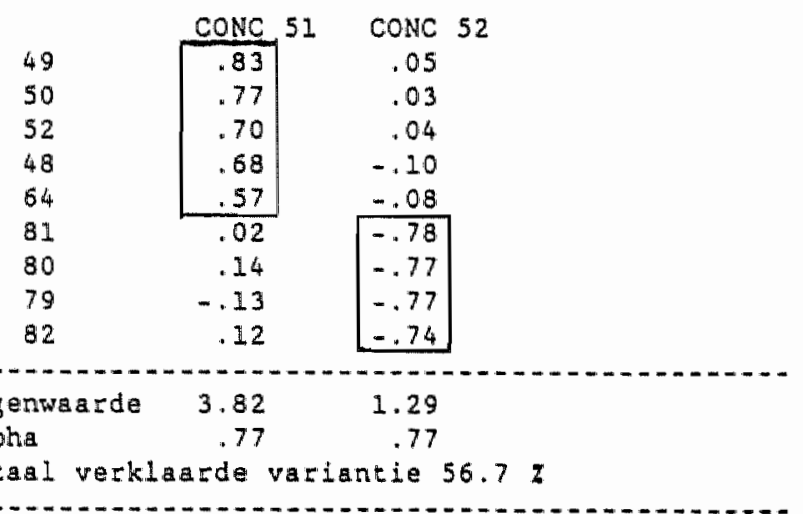


Bijlage IV, blad 4

Cortelatie-matrix additieve schalen

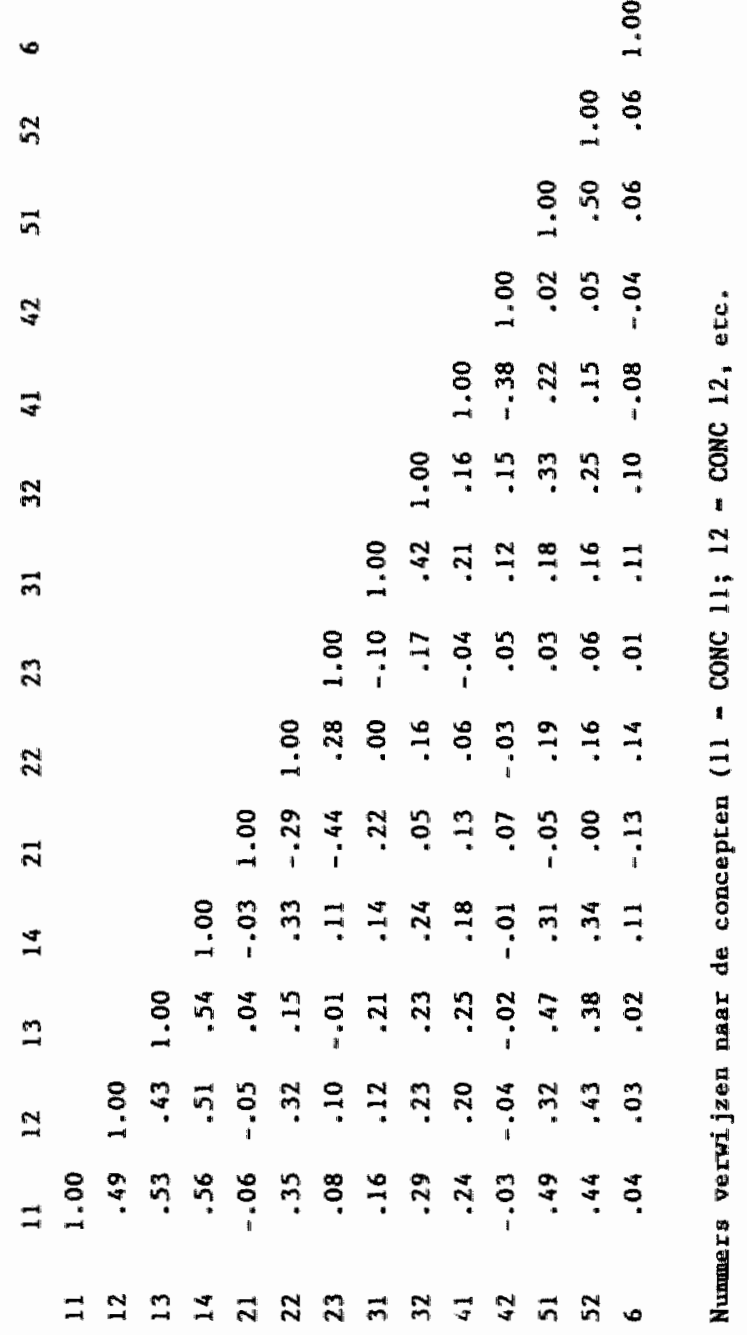


Bijlage $V$, blad 1

SOCLAAL STRUCTURELE ACHTERGRONDKENMERKEN EN HUN CATEGORIEEN

V1 Leeftiid

- Jonger dan 40 jaar

- Ouder dan 40 jaar

V2 Opleiding

$-\mathrm{HBO}$

- WO

- Overige

V3 Soort opleiding

- Sociaal/pedagogisch

- Economisch/administratief

- Technisch

- Overige

V4 Opleiding gelijk aan werk

- Ja

- Nee

V5 Werktijd in sector

-0 tot $5 \mathrm{jr}$.

- 6 tot $10 \mathrm{jr}$.

- 11 tot $20 \mathrm{jr}$.

- 21 tot $30 \mathrm{jr}$.

V6 Totaal werkzaam

- 0 tot $5 \mathrm{jr}$.

-6 tot $10 \mathrm{jr}$.

- 11 tot $20 \mathrm{jr}$.

- 21 jr. en langer

V7 Positie sector

- Arbeid

- Onderwijs

- Intermediaire organisaties

V8a Functie onderwijs

- Bestuur/directie

- Docent

- Overige

V8b Aard arbeidsorganisatie

- Profit

- Non-profit 
V8c Functie arbeid

- Directie/staf

- Afdeling

- Personeel/organisatie

- Overige

V8d Functie intermediaire sector

- Zie V8c

V8e Specifieke functie in beroepspraktijk of intermediaire sector

V8f Bedriifstak

- Open vraag

- Industrie

- Diensten

- Quartair

- Overige

$\mathrm{V} 8 \mathrm{~g}$ Bedriifsgrootte

- 0 tot 25 personen

- 26 tot 50 personen

- 5』 tot 100 personen

- 101 tot 250 personen

- 251 tot 500 personen

- 501 en meer personen

V9 Beslissende invloed in beleid *

- Zeker niet van toepassing

- Niet van toepassing

- Deels wel/deels niet van toepassing

- Van toepassing

- Zeer van toepassing

V10 Betrokken bii discussies

- Zie V9

V11 Betrokken bij beleidsontwikkeling - Zie V9

- Ingraad-index (ID)

- Niet genoemd (0)

- Eenmaal genoemd (1)

- Meer dan eenmaal genoemd (2)

* = V9, V10 en V11 zijn gedichotomiseerd zoals aangegeven en als zodanig in alle analyses gehanteerd, tenzij uitdrukkelijk anders vermeld. 
Bijlage $\mathrm{VI}$,

SIGNIFICANTIE EN RELEVANTIE VAN DE VERBANDEN TUSSEN DE SOCLAAL-STRUCTURELE ACHTERGRONDKENMERKEN EN DE NIET IN DE GECONSTRUEERDE SCHALEN OPGENOMEN ITEMS

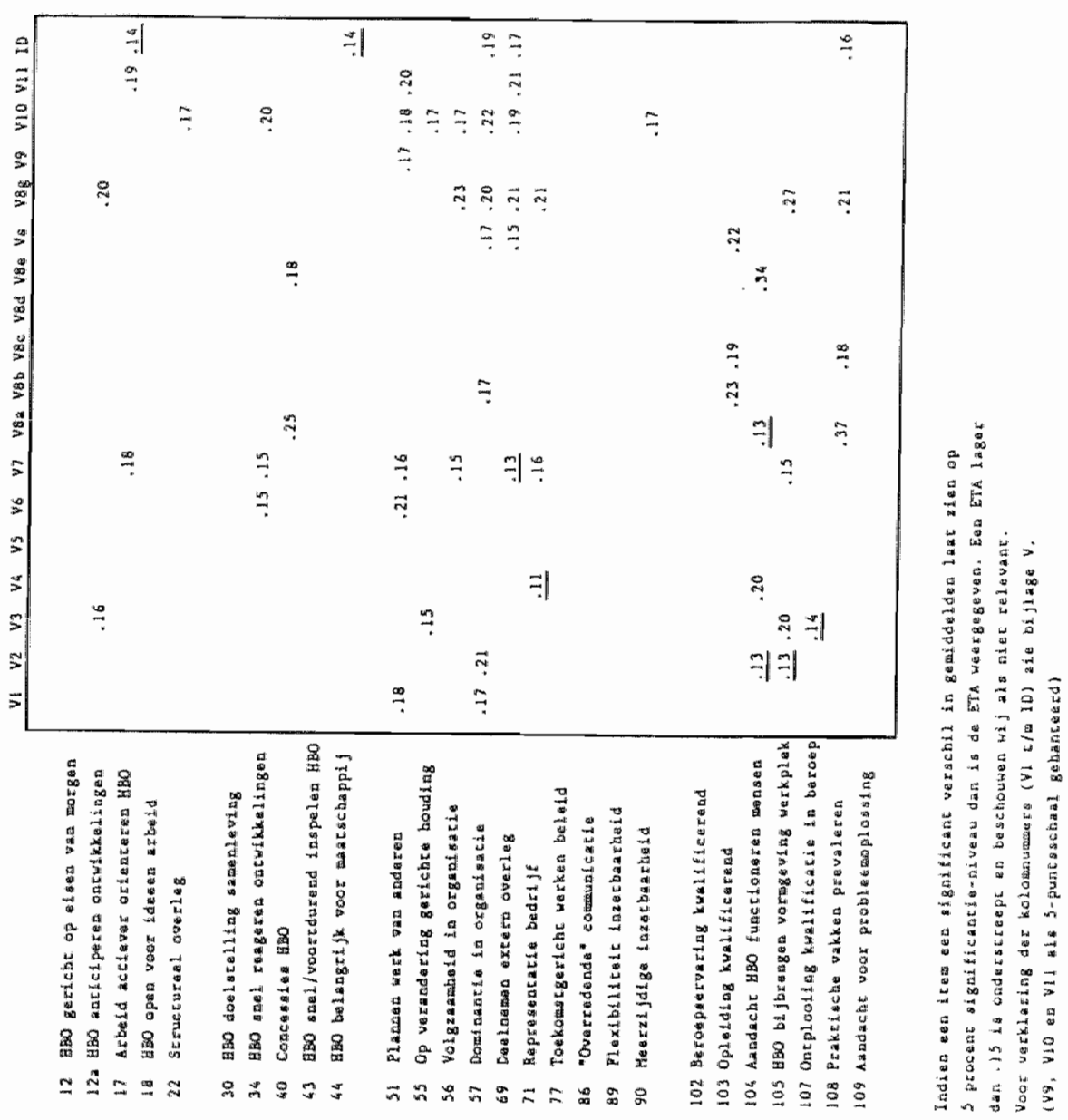


Bijlage VII, blad 1

SIGNIFICANTIE EN RELEVANTIE VAN DE VERBANDEN TUSSEN DE SOCLAAL-STRUCTURELE ACHTERGRONDKENMERKEN EN DE GECONSTRUEERDE ADDITIEVE SCHALEN

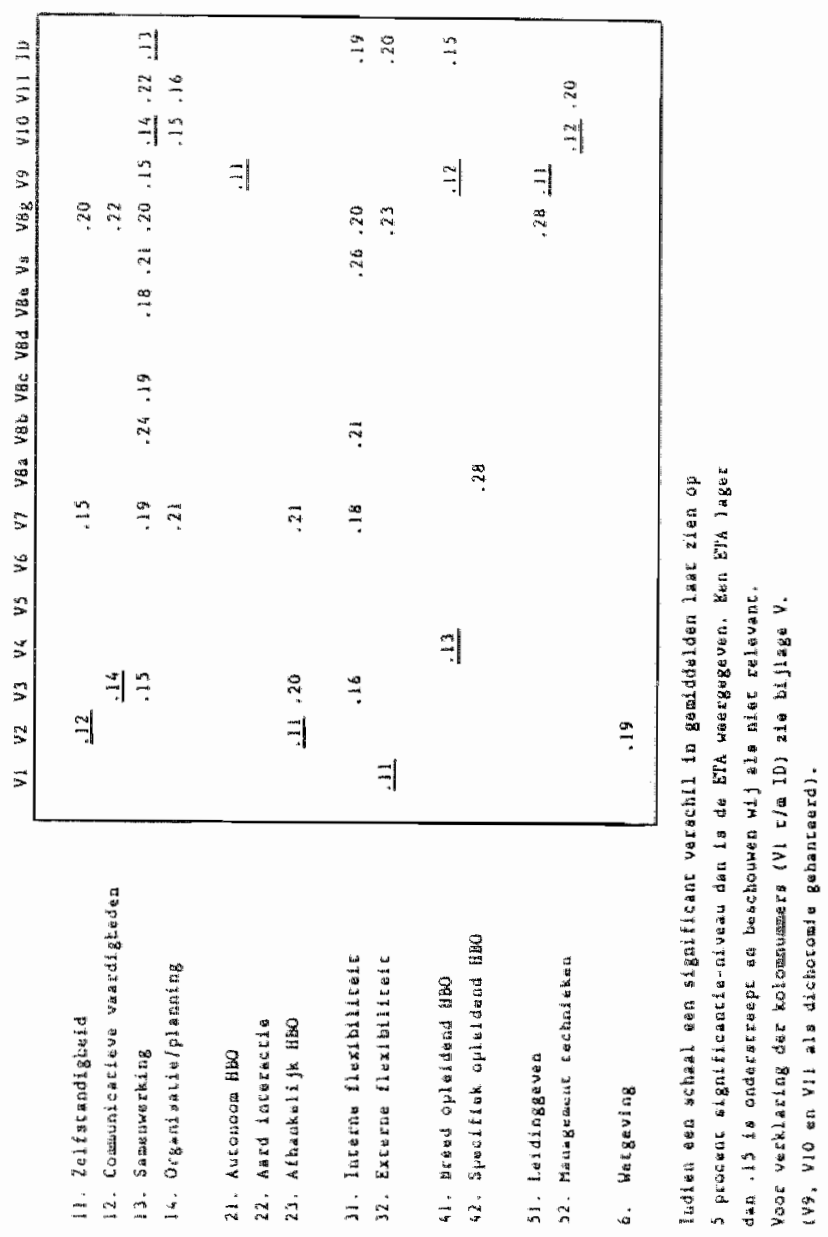


Bijlage VIII, blad 1

\section{CORRESPONDENTIE-ANALYSE}

MATRICES MET BETREKKING TOT KWALITEIT

- matrix van $x$-scores en y-punten (kenmerken)

\begin{tabular}{|c|c|c|c|c|}
\hline variable & afkorting & & DIM I: & DIM II: \\
\hline V 6 & kort wz & & 0.099 & 0.002 \\
\hline V 6 & lang wz & & -0.046 & -0.045 \\
\hline V 7 & arbeid & & 0.061 & -0.014 \\
\hline V 7 & onderwijs & & -0.151 & -0.043 \\
\hline V 7 & intermediair & & -0.125 & 0.156 \\
\hline$V 8 B$ & profit/s & & 0.104 & 0.099 \\
\hline V $8 B$ & non profit/s & & 0.016 & -0.066 \\
\hline$V 8 G$ & $0-50 \mathrm{wn}$ & & 0.116 & -0.114 \\
\hline $\mathrm{V} 8 \mathrm{G}$ & $51-250 \mathrm{wn}$ & & -0.031 & 0.152 \\
\hline V10 LA & betrokk. & - & 0.058 & 0.009 \\
\hline V10 HO & betrokk. & + & -0.144 & -0.006 \\
\hline V11 LA & discuss. & - & 0.030 & 0.012 \\
\hline V11 HO & discuss. & + & -0.222 & -0.049 \\
\hline $\mathrm{ID} \quad 0$ & reput. & 0 & 0.002 & 0.042 \\
\hline ID 1 & reput. & 1 & 0.089 & -0.013 \\
\hline $\mathrm{ID} \quad 2$ & reput. & 2 & -0.107 & -0.046 \\
\hline
\end{tabular}

- matrix van y-scores en kolompunten (conceptscores)

\begin{tabular}{lllcr}
\hline concept & afkorting & & DIM I: & DIM II: \\
\hline II LA & zelfst. & - & 0.025 & -0.055 \\
II HO & zelfst. & + & -0.034 & 0.056 \\
I2 LA & comm. & - & 0.052 & -0.035 \\
$12 \mathrm{HO}$ & comm. & + & -0.072 & 0.040 \\
$13 \mathrm{LA}$ & samenw. & - & 0.095 & 0.034 \\
$13 \mathrm{HO}$ & samenw. & + & -0.109 & -0.039 \\
$14 \mathrm{LA}$ & organ. & - & 0.124 & 0.031 \\
$14 \mathrm{HO}$ & organ. & + & -0.170 & -0.041 \\
$51 \mathrm{LA}$ & leiding & - & 0.032 & -0.108 \\
$51 \mathrm{HO}$ & leiding & + & -0.022 & 0.095 \\
$52 \mathrm{LA}$ & manag. & - & 0.131 & -0.026 \\
$52 \mathrm{HO}$ & manag. & + & -0.079 & 0.020
\end{tabular}


MATRICES MET BETREKKING TOT INTERACTIE

- matrix van $x$-scores en ry-punten (kenmerken)

\begin{tabular}{lllcr}
\hline variabele & afkorting & & DIM I: & DIMII: \\
\hline V 6 & lang wz & & -0.042 & 0.023 \\
V 6 & kort wz & & 0.052 & 0.023 \\
V 7 & arbeid & & -0.029 & 0.006 \\
V 7 & onderwijs & & 0.232 & 0.017 \\
V 7 & intermediar & & -0.184 & -0.110 \\
V 8 B & profit/s & & -0.039 & -0.074 \\
V 8 B & non profit/s & & -0.005 & 0.046 \\
V 8 G & 0-50 wn & & -0.051 & 0.040 \\
V 8 G & 51-250 wn & & -0.210 & 0.058 \\
V 9 HO & invloed & + & -0.012 & 0.047 \\
V 9 LA & invloed & - & -0.022 & 0.033 \\
V10 HO & betrokk. & + & 0.075 & -0.085 \\
V10 LA & betrokk. & - & 0.117 & -0.024 \\
ID 0 & reput. & 0 & -0.050 & -0.005 \\
ID 1 & reput. & 1 & -0.039 & -0.052 \\
ID 2 & reput. & 2 & 0.132 & 0.019
\end{tabular}

- matrix van y-scores en kolompunten (conceptscores)

\begin{tabular}{llcrr}
\hline cancept & afkorting & & DIM I: & DIMII: \\
\hline $21 \mathrm{LA}$ & auton & - & 0.015 & -0.063 \\
$21 \mathrm{HO}$ & auton & + & -0.011 & 0.048 \\
$22 \mathrm{LA}$ & inter & - & 0.020 & 0.058 \\
$22 \mathrm{HO}$ & inter & + & -0.019 & -0.053 \\
$23 \mathrm{LA}$ & afhank & - & 0.161 & -0.002 \\
$23 \mathrm{HO}$ & afhank & + & -0.141 & 0.002
\end{tabular}


Bijlage VIII, blad 3

MATRICES MET BETREKKING TOT STRUCTUUR

- matrix van $x$-scores en ry-punten (kenmerken)

\begin{tabular}{|c|c|c|c|c|}
\hline variabele & afkorting & & DIM I: & DIMII: \\
\hline V 6 & lang wz & & -0.030 & 0.032 \\
\hline V 6 & kort wz & & -0.039 & 0.088 \\
\hline V 7 & arbeid & & 0.012 & -0.040 \\
\hline V 7 & onderwijs & & 0.094 & 0.101 \\
\hline V 7 & intermediair & & -0.160 & 0.103 \\
\hline V $8 \mathrm{~B}$ & profit/s & & 0.052 & -0.107 \\
\hline V $8 B$ & non profit/s & & -0.023 & 0.022 \\
\hline $\mathrm{V} 8 \mathrm{G}$ & $0-50 \mathrm{wn}$ & & 0.005 & 0.066 \\
\hline V $8 \mathrm{G}$ & $51-250$ wn & & -0.178 & -0.099 \\
\hline V 9 LA & invloed & - & 0.023 & 0.002 \\
\hline V $9 \mathrm{HO}$ & invloed & + & -0.137 & 0.001 \\
\hline V11 LA & discuss & - & -0.001 & -0.015 \\
\hline V11 HO & discuss & + & 0.051 & 0.097 \\
\hline ID 0 & reput & 0 & -0.114 & 0.011 \\
\hline ID 1 & reput & 1 & 0.175 & -0.030 \\
\hline ID 2 & reput & 2 & 0.161 & 0.009 \\
\hline
\end{tabular}

- matrix van y-scores en kolompunten (conceptscores)

\begin{tabular}{lllrr}
\hline concept & afkorting & & DIM I: & DIMII: \\
\hline $31 \mathrm{LA}$ & int. flexi & - & 0.080 & -0.089 \\
$31 \mathrm{HO}$ & int. flexi & + & -0.074 & 0.084 \\
$32 \mathrm{LA}$ & ext. flexi & - & 0.101 & 0.040 \\
$32 \mathrm{HO}$ & ext. flexi & + & -0.094 & -0.037 \\
$41 \mathrm{LA}$ & breed op & - & 0.093 & 0.037 \\
$41 \mathrm{HO}$ & breed opl & + & -0.079 & -0.029 \\
$42 \mathrm{LA}$ & specif. op & - & 0.000 & 0.017 \\
$42 \mathrm{HO}$ & specif. opl & + & -0.006 & -0.023
\end{tabular}




\section{SCHEMATISCH OVERZICHT VAN DE VRAGENLIJST ZOALS GEBRUIKT BIJ HET SURVEY-ONDERZOEK}

\begin{tabular}{llc}
\hline Variabelen-categorie & Vorm & Aantal \\
\hline $\begin{array}{l}\text { Soc. structurele kenmerken } \\
\text { Invloed/Discussie/Beleid } \\
\text { m.b.t. het theoretisch concept } \\
\text { "Interactie" }\end{array}$ & voorgecodeerd & 10 \\
$\begin{array}{l}\text { m.b.t. het theoretisch concept } \\
\text { "Structuur en Organisatie" }\end{array}$ & 5 punts-schalen & 3 \\
$\begin{array}{l}\text { m.b.t. het theoretisch concept } \\
\text { "Kwaliteit" }\end{array}$ & 5 punts-schalen & 16 \\
& & 45 direct \\
& & 8 indirect \\
\hline
\end{tabular}

De vragen m.b.t. sociaal-structurele kenmerken en m.b.t. invloed/discussie/ beleid zijn tevens weergegeven in Bijlage $\mathrm{V}$.

In Bijlage I, blad $2 \mathrm{t} / \mathrm{m} 5$ alsmede in deze bijlage is de essentie van alle m.b.t. de theoretische concepten gebruikte variabelen, kort weergegeven.

\section{RUBRIEK 1: PERSOONLUKE GEGEVENS}

RUBRIEK 2: RESPONDENTKENMERKEN

\section{- Leeftijd}

- Opleiding qua laatstbehaalde diploma

- Opleiding qua sector/richting

- Sector waarin werkzaam dezelfde als die waarcp opleiding was gericht

- Hoe lang werkzaam in deze sector

- Hoe lang werkzaam in totaliteit na afstuderen

- Sector waarin werkzaam

- In welke soort functie werkzaam

- In welke functie werkzaam

- Tot welke sector behoort bedrijf waar werkzaam

- Grootte bedrijf gerekend in arbeidsplaatsen 
Bijlage IX, blad 2

RUBRIEK 3: INVLOED EN BETROKKENHEID BU DISCUSSIE EN BELEID/ STATEMENTS/S PUNTS-SCHAAL.

- Ik denk dat ik op het totstandkomen van het toekomstig HBO vanuit en door mijn werk, organisatie enz, beslissende invloed kan uitoefenen.

- Ik ben in practische zin en regelmatig betrokken bij discussie, meningsvorming over het $\mathrm{HBO}$ in eigen kring en/of daarbuiten.

- Ik ben in practische zin en regelmatig betrokken bij het concreet ontwikkelen en voorbereiden van beleid met betrekking tot het toekomstig HBO.

\section{RUBRIEK 4: INTERACTIE/STATEMENTS/S PUNTS-SCHALEN}

- Het HBO zal meer dan nu gericht moeten zijn op de eisen van morgen

- Het HBO zal op de te verwachten ontwikkelingen in de beroepspraktijk dienen te anticiperen.

- Het HBO maakt in de toekomst niet zelf uit wat de eisen in de beroepspraktijk zijn, maar stelt zich afhankelijk op ten opzichte van het werkveld.

- Het HBO moet zelf gaan uitmaken welke de eisen zullen zijn, die op de toekomstige werkplek aan afgestudeerden zullen worden gesteld.

- Het HBO moet in de toekomst bereid zijn tot een open dialoog met de arbeidssector, waarop de opleidingen zijn gericht.

- Het HBO moet in de toekomst veel meer aandacht schenken aan het voorbereiden van de leerlingen op hun feitelijke beroepsuitoefening op de arbeidsmarkt.

- De arbeidssector moet in de toekomst actiever georiënteerd zijn op het HBO.

- Het HBO moet in de toekomst meer open staan voor ideëen uit de arbeidssector.

- Een HBO-instituut zal ook in de toekomst een autonoom instituut met eigen verantwoordelijkheden moeten zijn; in die zin dat de eisen uit de werkpraktijk niet bepalend behoeven te zijn bij de inrichting en doelstelling van het HBO.

- Opleidingspraktijk en beroepspraktijk zullen qua sfeer en klimaat in de toekomst twee duidelijk gescheiden werelden moeten zijn.

- Het HBO moet in de toekomst vooral een autonoom instituut zijn, in die zin dat het zelf bepaalt aan welke eisen werkers in de beroepspraktijk zullen moeten voldoen.

- Er moet in de toekomst regelmatig gestructureerd overleg zijn over het bevorderen van meer contact tussen beroepsonderwijs en beroepspraktijk. 
- Het HBO zal de ontwikkelingen, zoals die zich in de arbeidssector voordoen ten aanzien van functie-inhouden, op de voet moeten volgen.

- De opleidingen binnen het HBO bevatten beroepsgerichte en algemeen vormende vakken. Het aandeel van de algemeen vormende vakken binnen het totale opleidingspakket moet in de toekomst toenemen.

- Het HBO moet voor stages in de toekomst een grotere plaats inruimen.

- Het HBO moet in de toekomst georiënteerd zijn op de eisen uit de werkpraktijk en daarmee met de werkpraktijk in de vormgeving van de opleiding serieus rekening houden; Deze eisen uit de werkpraktijk moeten het uitgangspunt vormen voor de inrichting van de opleidingspraktijk.

RUBRIEK 5: TOEKOMSTIGE ORGANISATIE EN STRUCTUUR VAN HET HBO STATEMENTS/5 PUNTS-SCHALEN

- Het hoger beroepsonderwijs moet zijn doelstellingen vooral ontlenen aan de toekomstige eisen die de samenleving aan het onderwijs als instituut zal stellen.

- Hoger beroepsonderwijs, zoals we dat nu kennen, zal in de toekomst veel meer dan nu in de broepspraktijk zelf moeten plaatsvinden bv. via werkcontacten en stage-overeenkomsten.

- Hoger beroepsonderwijs moet in zelfstandige kleine overzienbare eenheden worden gegeven.

- Het HBO moet in de toekomst snel en adequaat reageren op ontwikkelingen in de beroepspraktijk, dit betekent dat wijzigingen in leerplannen en werkwijzen snel realiseerbaar moeten zijn.

- De toekomstige betekenis van het beroepsonderwijs voor de samenleving moet ten opzichte van de huidige betekenis die eraan wordt gehecht sterk worden gerelativeerd.

- Het op elkaar betrokken zijn van opleidings- en beroepspraktijk zal meer moeten gaan via nationale regelgeving dan via locale overleg- en werkeenheden.

- Een toekomstig HBO-diploma zal voortaan moeten bestaan ui een verzameling (deel-)certificaten, die mensen verwerven, aangepast aan de individuele behoeften van degenen die deze certificaten verwerven.

- Het leerlingstelsel voor "werkers in opleiding" moet ook voor beroepen en functies op HBO-niveau worden ingevoerd.

- Aan studenten moet veel meer invloed worden gegeven bij het vormgeven van de feitelijke onderwijspraktijk in het HBO. 
- Om het rendement van het Hoger Beroepsonderwijs voor de maatschappelijke omgeving i.c. de maatschappelijke bruikbaarheid te vergroten dienen er in de sfeer van de onderwijsstructuur concessies te worden gedaan.

- Het effectief op elkaar betrokken zijn van opleidings- en beroepspraktijk zal meer moeten gaan via locale werkeenheden dan via nationale regelgeving.

- De beroeps-opleidingen binnen het toekomstig HBO moeten vooral gericht zijn op de voorbereiding voor specifieke beroepen. Hoe specifieker een opleiding, hoe beter het is.

- Hogere beroepsopleidingen moeten snel en woortdurend op wijzigingen in de beroepspraktijk inspelen.

- De rol van het HBO zal in de toekomst, waar het gaat om het voorbereiden van mensen op hun maatschappelijk functioneren veel belangrijker moeten worden.

- Het toekomstig HBO moet een student vooral op een breed scala van levenssituaties voorbereiden.

- Het toekomstig HBO moet niet meer, zoals dat nu het geval is, gericht zijn op eindstadia van kwalificatie waarbij afgeronde pakketten met een einddiploma worden aangeboden.

- Instellingen voor HBO moeten in de toekomst meer in lokale gemenschappen geintegreerd zijn en daaraan direct ten goede komen.

\section{RUBRIEK 6A: TOEKOMSTIGE KWALITETTEN/STATEMENTS/5 PUNTS-SCHALEN}

Wenselijkheid van:

- management van organisaties

- organisatie-ontwikkeling

- organisatie-verandering

- het plannen van werk van anderen

- het ontwikkelen van beleid van het bedrijf/instelling

- een actieve werkhouding

- een klantgerichte instelling

- op verandering van maatschappelijke structuren gerichte grondhouding

- volgzaamheid ten opzichte van de organisatie

- dominantie en een vernieuwende opstelling ten opzichte van de organisatie

- het ontwikkelen van initiatieven

- het organiseren van hun eigen werk

- het plannen van eigen werk 
- het nemen van beslissingen

- het ontwikkelen van ideëen

- samenwerken met collegae

- leidinggeven aan ondergeschikten

- samenwerken met superieuren

- samenwerken met vrijwilligers

- vanuit en door de organisatie samen te werken met andere instellingen

-. effectief "naar buiten" optreden

- deelnemen aan extern overleg

- deelnemen aan onderhandelingen

- het bedrijf of de instelling adequaat representeren

- vakkundig informatie verschaffen en vergaren in relatie tot de omgeving van een bedrijf of instelling

- omgaan met veranderingen in de beroepspraktijk

- individuen begeleiden bij verandering

- afwegingen maken en keuzen doen

- omgaan met veranderingen in de samenleving

- toekomstgericht kunnen werken aan de ontwikkeling van beleid

- technieken voor registratie van gegevens

- technieken voor effectbepalend onderzoek

- technieken voor marketing

- technieken voor het werven van fondsen

- technieken voor budgetbewaking

- rapportage-technieken/vaardigheden

- mondelinge uitdrukkingswaardigheden

- schriftelijke uitdrukkingsvaardigheden

- overredende vaardigheden bij communicatie

- inlevings- en invoelingsvermogen bij communicatie

- persoonlijke flexibiliteit

- flexibiliteit qua inzet

- meerzijdige inzetbaarheid in de werksituatie

- algemeen opgeleide studenten

- specifiek opgeleide studenten 
Verzamelvaag ta.v. kwaliteitsaspecten/5 punts-schalen

- functioneren in en t.o.v. de eigen organisatie

- houding, opstelling in de beroepspraktijk

- zelfstandigheid in de beroepspraktijk

- samenwerking met anderen binnen de eigen organisatie

- samenwerking met anderen buiten de eigen organisatie

- anticiperen op de toekomst/omgaan met vernieuwingen

- verslaglegging, registratie, effectbepalingstechnieken

- communicatieve vaardigheden

- flexibiliteit qua (meerzijdige) inzetbaarheid

RUBRIEK 6B: OVERIGE KWALTTETSASPECTEN/STATEMENTS/5 PUNTSSCHAAL

- De beroepservaring op zichzelf moet meer kwalificerend zijn dan het genoten beroepsonderwijs.

- De beroepsopleiding op zichzelf moet meer kwalificerend zijn dan de beroepspraktijk.

- HBO moet in de toekomst veel aandacht schenken aan de specifieke eisen die het functioneren van mensen in organisaties stelt.

- Toekomstig HBO moet mensen niet alleen een set kwalificaties meegeven voor het beroep op zichzelf, maar ze bijbrengen hoe ze zelf hun functie/werkplek in de praktijk kumen vormgeven.

- Toekomstig HBO moet zich niet richten op een beroep of een groep van beroepen, maar moet algemene kwalificatie-aspecten tot uitgangspunt nemen bij de vormgeving van de onderwijspraktijk.

- De beroepspraktijk moet zo worden ingericht dat de op school bijgebrachte kwalificaties maximaal tot hun recht kunnen komen.

- In toekomstig HBO moeten practische vakken prevaleren boven theoretische.

- Het HBO moet in de toekomst aandacht schenken aan het ontwikkelen van het vermogen van studenten om tot snel begrip, doorzicht in problemen en de oplossing van problemen te komen. 
- De arbeidssector

- Industrie/Bouw c.a. 73

- Comm.dienstverlening 54

- Niet comm.dienstverlening 53

- Overheid en overheidsinstellingen

- Overigen

- De onderwiissector

- Wetenschappelijk onderwijs 7

- Vertalersopl. en bestuursonderwijs 6

- Soc.Ped. en Gezondheidszorgonderw. 12

- Kunstonderwijs 5

- Opleiding voor leraren 9

- Middenst. en Ec.Adm.onderwijs 9

- Technisch en labor. onderwijs 11

- Huish. en nijverh.onderwijs 4

- Overigen 7

Totaal

- De sector intermediaire organisaties

- Contactcentra onderwijs-arbeid

- School- en Beroepskeuzebureaus c.a.

- GAB's/DBA etc.

- Overigen 
Bijlage XI, blad 1

\section{LISST VAN AFKORTINGEN}

$\begin{array}{ll}\text { Beleid } & \text { Betrokkenheid bij beleidsontwikkeling } \\ \text { Beslis } & \text { Invloed op de beleidsontwikkeling en -uitvoering } \\ \text { BRD } & \text { Bondsrepubliek Duitsland } \\ \text { CNC } & \text { Computerized Numerique Control } \\ \text { COA } & \text { Contactcentrum Onderwijs - Arbeid }\end{array}$

Conc

Concept

DBA

Districtsbureau voor de Arbeidsvoorziening.

Disc Betrokkenheid bij discussie

Econ.Adm. Economisch-Administratief

ETIL

Economisch Technologisch Instituut Limburg

GAB

Gewestelijk Arbeidsbureau

HBO

Hoger Beroepsonderwiijs

$\mathrm{HO}$

Hoger Onderwijs

HOAK

Hoger Onderwijs Autonomie en Kwaliteit

HOOP

Hoger Onderwijs en Onderzoek Plan

HOTM

ID

Hoger Onderwijs Technologie en Marktsector

Ingrd

Ingraad

KUN

Ingraad

OLC

Katholieke Universiteit Nijmegen

Open Learning Center

RL

SBI

Rijksuniversiteit Limburg

SER

Standaard Beroepen Informatie-systeem

Soc.Ped.

Sociaal Economische Raad

Techn.

Sociaal-Pedagogisch

Technisch 



\section{COLOFON}

Uitgave:

L.L.M. Frederix, Munstergeleen, november 1988

Druk:

Huntjens b.v., Stein 